BHI-01299

Rev. 0

\title{
Alternative Evaluation for the REDOX (202-S) Plutonium Loadout Hood
}


TRADEMARK DISCLAIMER

Reference herein to any specific commercial product, process, or service by trade name, trademark, manufacturer, or otherwise, does not necessarily constitute or imply its endorsement, recommendation, or favoring by the United States Government or any agency thereof or its contractors or subcontractors.

This report has been reproduced from the best available copy. Available in paper copy and microfiche.

Available to the U.S. Department of Energy

and its contractors from

Office of Scientific and Technical Information

P.O. Box 62

Oak Ridge, TN 37831

(615) $576-8401$

Available to the public from the U.S. Department of Commerce National Technical Information Service

5285 Port Royal Road

Springfield, VA 22161

(703) $487-4650$

Printed in the United States of America

DISCLM-5.CHP (8-91) 
BHI-01299

Rev. 0

OU: N/A

TSD: N/A

ERA: N/A

\section{APPROVAL PAGE}

Title: $\quad$ Altermative Evaluation for the REDOX (202-S)

Plutonium Loadout Hood

Approval: J. J. McGuire,

Project Manager, Surveillance/Maintenance and Transition Projects

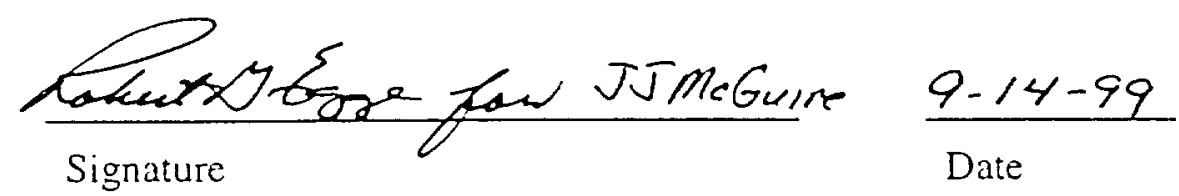

The approval signature on this page indicates that this document has been authorized for information release to the public through appropriate channels. No other forms or signatures are required to document this information release. 
BHI-01299

Rev. 0

\title{
Alternative Evaluation for the REDOX (202-S) Plutonium Loadout Hood
}

\author{
Authors \\ C. J. Kemp \\ N. R. Kerr \\ R. S. Rajagopal \\ Bechtel Hanford, inc.
}

Date Published

September 1999 
BHI-01299

Rer. 0

\section{CONTE:ITS}

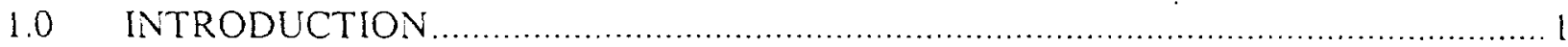

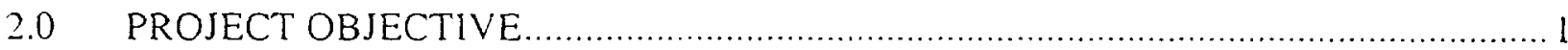

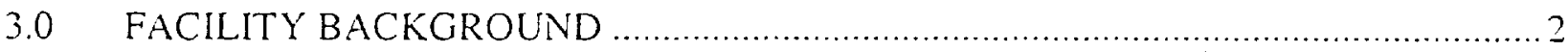

4.0 BACKGROUND OF PLUTONIUM LOADOUT HOOD AND EXTENT OF

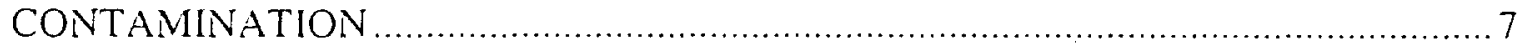

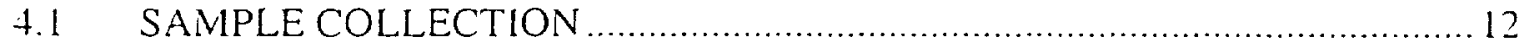

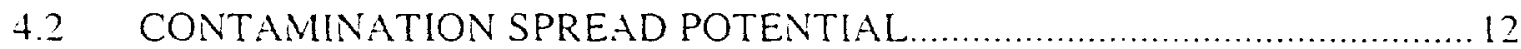

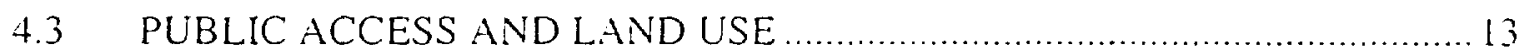

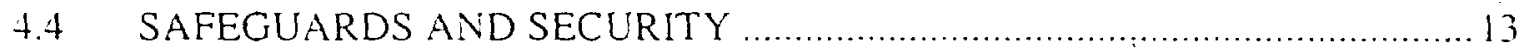

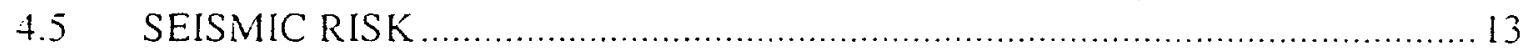

4.6 PLUTONIUM LOADOUT HOOD INVENTORY ................................ 14

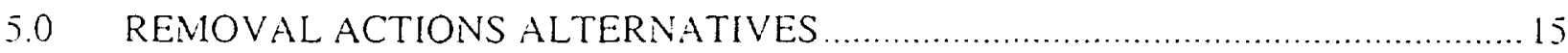

5.1 CONTINUED SUR VEILLANCE AND MAINTENANCE ACTION ............. 15

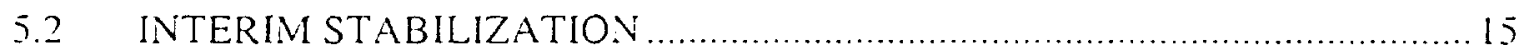

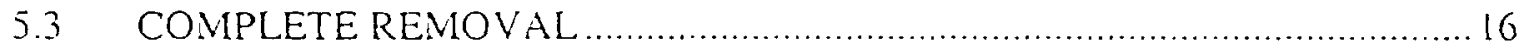

6.0 IDENTIFICATION OF STANDARDS AND REQUIREMENTS $\ldots \ldots \ldots \ldots \ldots \ldots \ldots \ldots \ldots \ldots$

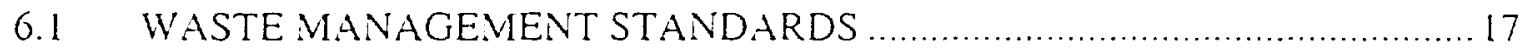

6.2 AIR EMISSION CONTROL STANDARDS ........................................... is

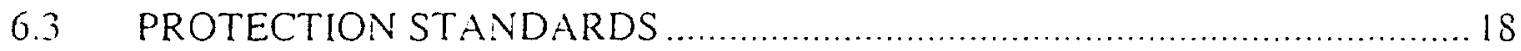

6.4 POLYCHLORINATED BIPHENYLS .................................................. Is

6.5 ENVIRONMENT, SAFETY, AND HEALTH STANDARDS ….................. 19

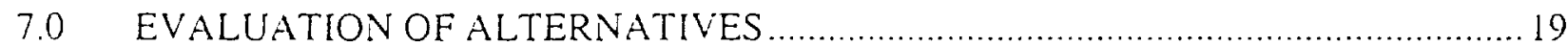

7.1 LONG-TERM EFFECTIVENESS ........................................................ 19

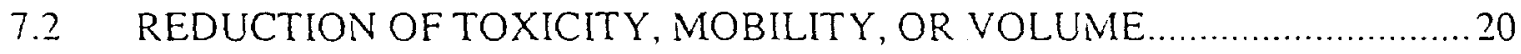

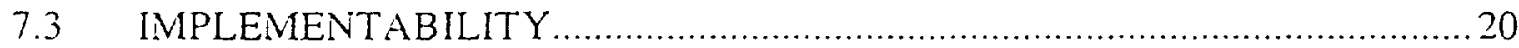

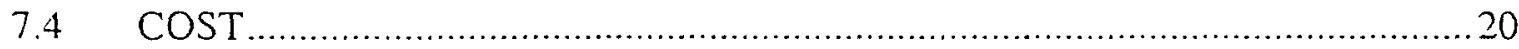

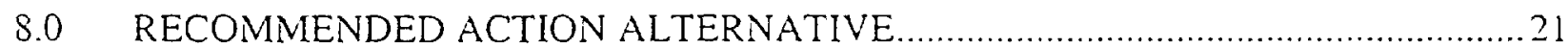

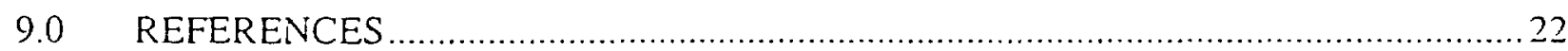

\section{APPENDIX}

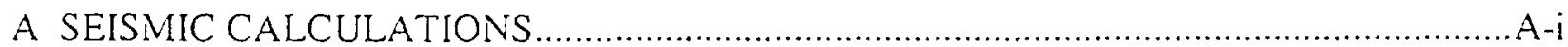




\section{FIGURES}

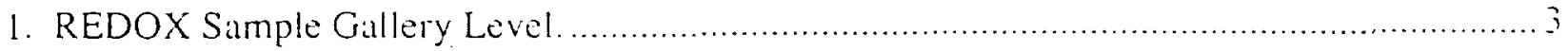

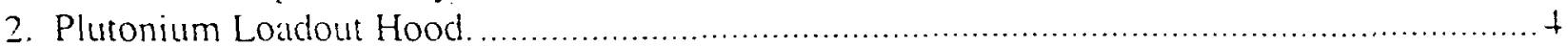

3. Top View of the 202-S Plutonium Loadout Hood.......................................................

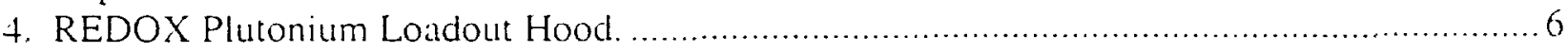

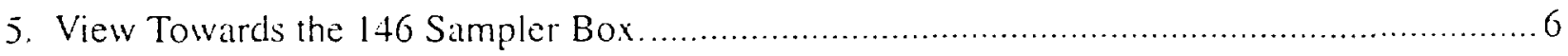

\section{TABLES}

1. Major Plutonium Loadout Hood Process Vessels................................................................ 7

2. Plutonium Loadout Hood Sump Sludge Multiphase Sample Results................................... S

3. Tank E-17 Process Piping Leach Sample Results.................................................... 10

4. Plutonium Loadout Hood Technical Smcar Sample Results................................................. 11

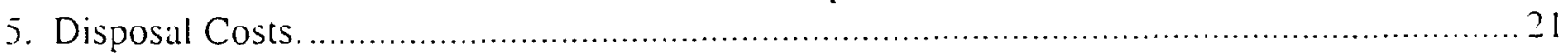


BHI-01299

Rev. 0

\subsection{INTRODLCTION}

The 100, 200, 300, and 1100 Areals of the Hanford Site were placed on the U.S. Environmental Protection Agency's (EPA) National Priorities List in November 1989 under the Comprehentisive Environmental Response. Compensation. and Liability Act of 1980 (CERCLA). Located in the 200 Areas is the inactive 202-S Reduction Oxidation (REDOX) Facility, which is managed by the Bechtel Hanford, Inc. (BHI) Surveillance/Maintenance \& Transition project. This facility is contaminated from nuclear material processes related to nuclear matcrial separation from Hanford Site facility operations.

This alternative evaluation report describes the altematives and selection criterial based on the necessary protective requirements to maintain the REDOX Plutonium Loadout Hood in a sate and stable condition awaiting a final waste response iction.

The U.S. Department of Energy (DOE), Richlind Operations Office (RL), in cooperation with the EPA and the Washington State Department of Ecology (Ecology), are directing and managing cleanup of contaminated ficilities and waste sites at the Hanford Site. This evaluation compares three alternatives for disposition of the REDOX Plutonium Loadout Hood:

1. No action

2. Stabilization of the interior surfices of the hood

3. Removal of the hood.

The EPA has verbally instructed that unless complete removal (option 3) of the Plutonium Loadout Hood is selected, al letter report should be prepared documenting the analysis for selection of no action or contaminant stabilization. If complete removal of the hood is chosen. then EPA would require an Engineering Evaluation/Cost Anulysis (EE/CA) be prepared.

\subsection{PROJECT OB.JECTIVE}

The objective of this alternative determinition document is to provide information about the options for safely dealing with the REDOX (202-S) Plutonium Loadout Hood. These options include the criteria to reduce future risks to the 202-S Facility, workers, and the environment in the event of failure of engineered containment systems at the facility as well as the associated costs.

Three options are considered in this report:

- First option: Includes continuing current surveillance and maintenance (S\&M) of the hood with continuing routine inspections and radiological surveys.

- Second option: Includes stabilizing the hood interior and exterior to prevent potential contamination spread and allow shutdown of the 296-S-2 stack.

- Third option: Includes complete removal of the Plutonium Loadout Hood and its attached piping and components and disposal under a CERCLA removal action. 
BHI-01299

Rev. 0

\subsection{FACILITY BACKGROUND}

The REDOX Facility (202-S), located in the 200 West Area of the Hanford Site. was constructed between 1950 and 1952 and became the first large-scale, continuous-flow, solvent-extraction process plant built in the United States for the recovery of plutonium from irradiated uranium fuel. The extraction process, which replaced the batch precipitation methods first used at the Hanford Site, was designed to separate uranium, plutonium, and neptunium as individual product streams from associated fission products in the imadiated fuel.

The 202-S Facility is a reinforced-concrete structure consisting of the canyon areit; the galleries, storige, sample, pipe, operating, and crane cab; the silo area; the east end: and the attached service areas. The building is $142.6 \mathrm{~m}(468 \mathrm{ft})$ long and $49 \mathrm{~m}(16 \mathrm{lf})$ wide. The canyon areal is $25.2 \mathrm{~m}(\mathrm{~S} 3 \mathrm{ft}$ ) high, with $18.2 \mathrm{~m}$ (60 ft) abovegrade. The silo areal is $40.2 \mathrm{~m}$ ( $132 \mathrm{ft})$ high, with $35.6 \mathrm{~m}(117 \mathrm{ft})$ abovegrade. The Plutonium Loadout Hood is located at the west end of the North Sample Gallery (Figure 1). It received plutonium-rich solutions from the REDOX separations process and, in a two-step process, concentratted the solutions in the E- 16 preconcentrator and E-17 concentrator, respectively, to reach the required concentrations. The concentrated solution was transferred from the E-17 concentrator to the product removal cans in 30-L batches for transfer to the 234-5Z Facility for final processing.

The Plutonium Loadout Hood operated from 1951 until 1955 when it was taken out of service and flushed with nitric acid solutions. It was replaced with the 233-S Facility. The REDOX Facility continued to operate until it was shut down in 1967. Deactivation of the facility started in 1967 and was completed in 1969. Since deactivation. S\&M operations halve been performed it the REDOX Facility.

The Plutonium Loadout Hood (Figure 2, 3, 4 , and 5) is composed of a metal frame supporting a series of Lexan ${ }^{r M l}$ panels. This enclosure isolates the process vessels and piping inside the hood from the North Sample Gallery. The Lexan palt of the hood is approximately $2.55 \mathrm{~m}$ ( $8 \mathrm{ft} 6 \mathrm{in}$.) high and sits on a raised concrete curb $15.2 \mathrm{~cm}(6 \mathrm{in}$.) high. The topmost $0.6 \mathrm{~m}(2 \mathrm{ft})$ of the hood is enclosed by stainless-steel panels. The hood is contigured in an " $\mathrm{L}$ " shape with the base leg $3.4 \mathrm{~m}(\mathrm{l} 1 \mathrm{ft})$ long and $1.5 \mathrm{~m}(5 \mathrm{ft})$ wide and the other leg $5.2 \mathrm{~m}(17 \mathrm{ft})$ long and $1.5 \mathrm{~m}(5 \mathrm{ft})$ wide. Originally, this section of the hood was $6.4 \mathrm{~m}(21 \mathrm{ft})$ long, but a section of frame and paneling at the east end was removed, along with the equipment associated with the product removal can, at the completion of loadout hood operations in 1955. A metal panel was used to cover the opening left by removing the east-end section. The two stainless-steel pipes that were originally connected to the equipment that filled the product removal cans, a fill line from the E- 17 concentrator and a vacuum return line to the E-2I plutonium transfer trap tank, were cut and now extend outside the enclosure approximately $10 \mathrm{~cm}(4 \mathrm{in}$.) from the surface of the metal panel. A 15.2-cm (6-in.) cubical sump, equipped with a vacuum transfer jet, is located at the northwest comer of a depression in the hood. This sump also received drain overflow from the 233-S pipe trenches that have been isolated by the 233-S decommissioning task.

\footnotetext{
'Lexan is a tradename of the General Electric Company, Pittsfield, Massachusetts.
} 
BHI-0L 299

Rev. 0

Figure 1. REDOX Sample Gallery Level.

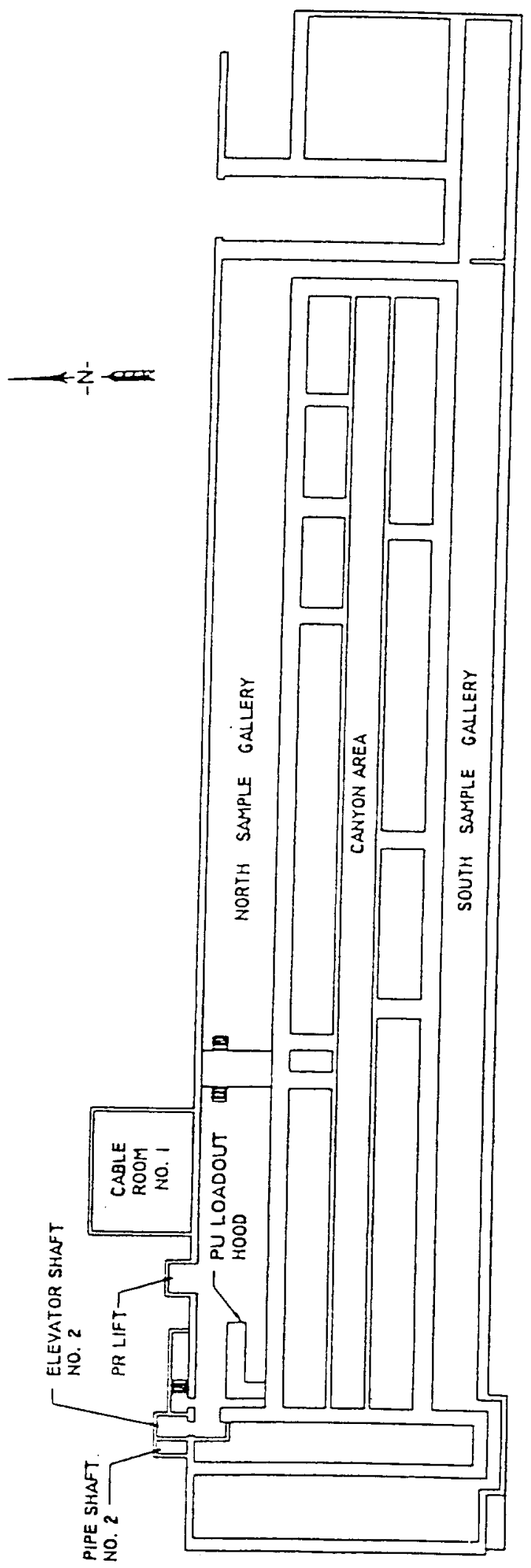


Figure 2. Plutonium Loadout Hood.

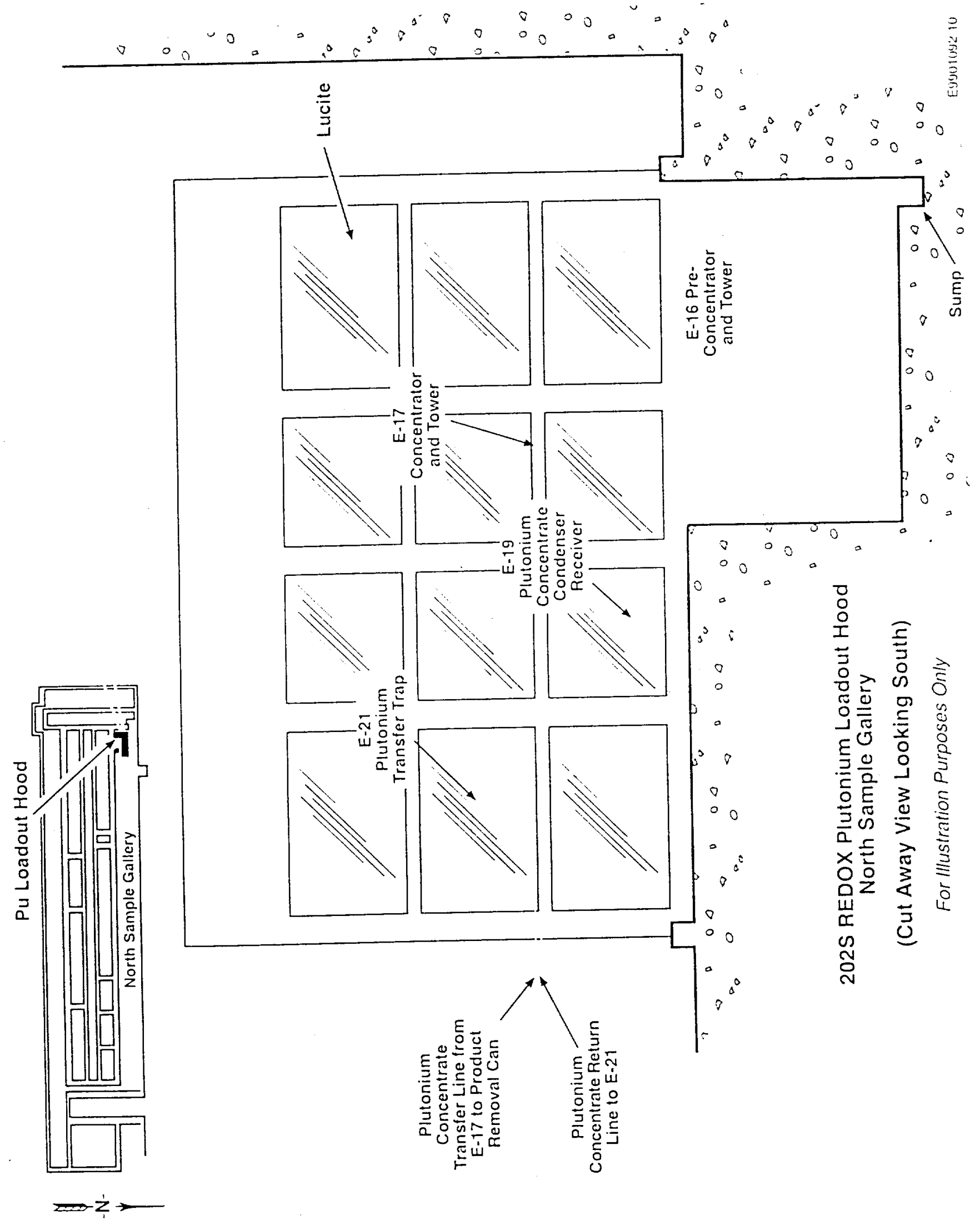


Figure 3. Top View of the 202-S Plutonium Loadout Hood.

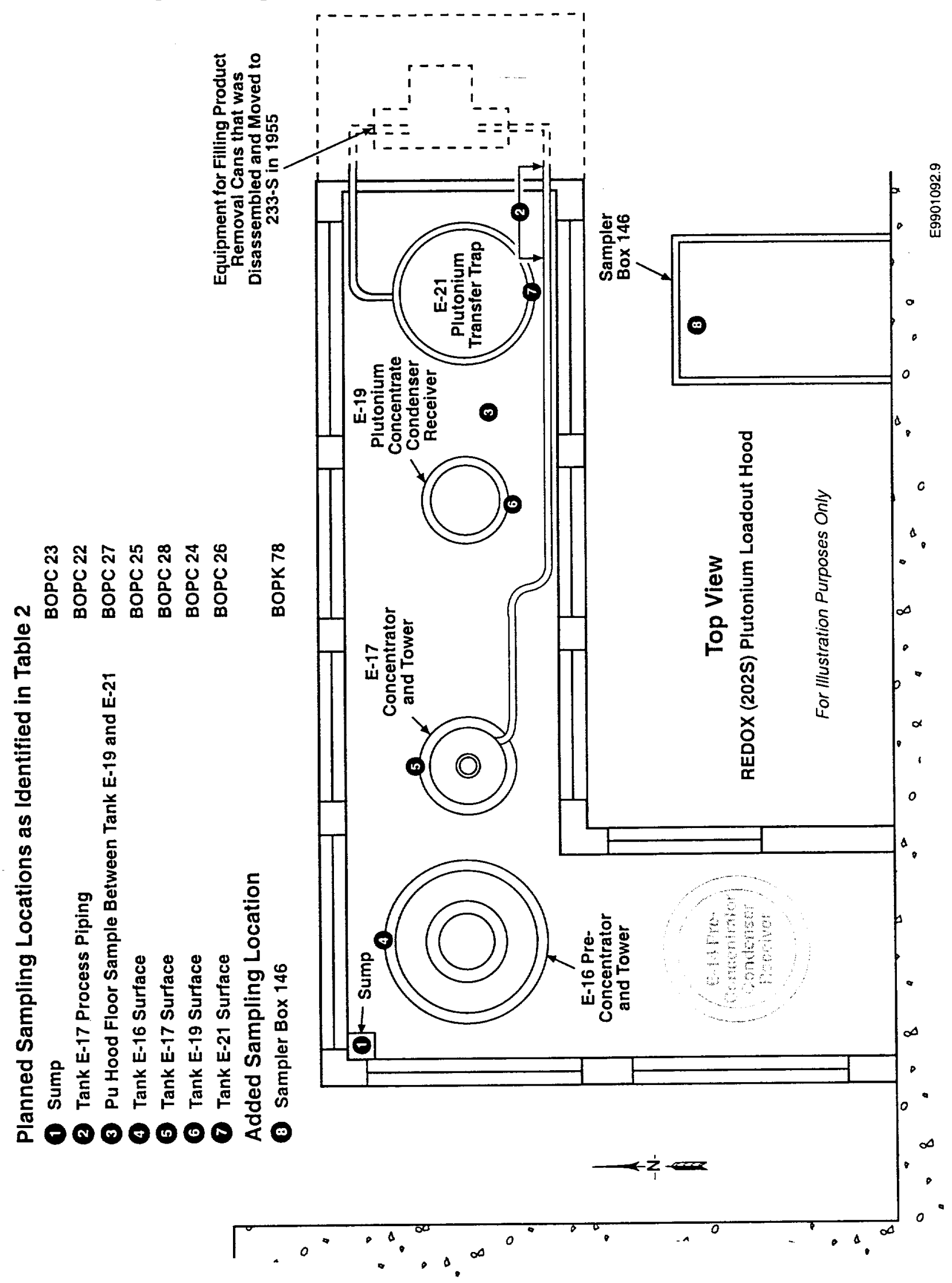


Figure 4. REDOX Plutonium Loadout Hood.

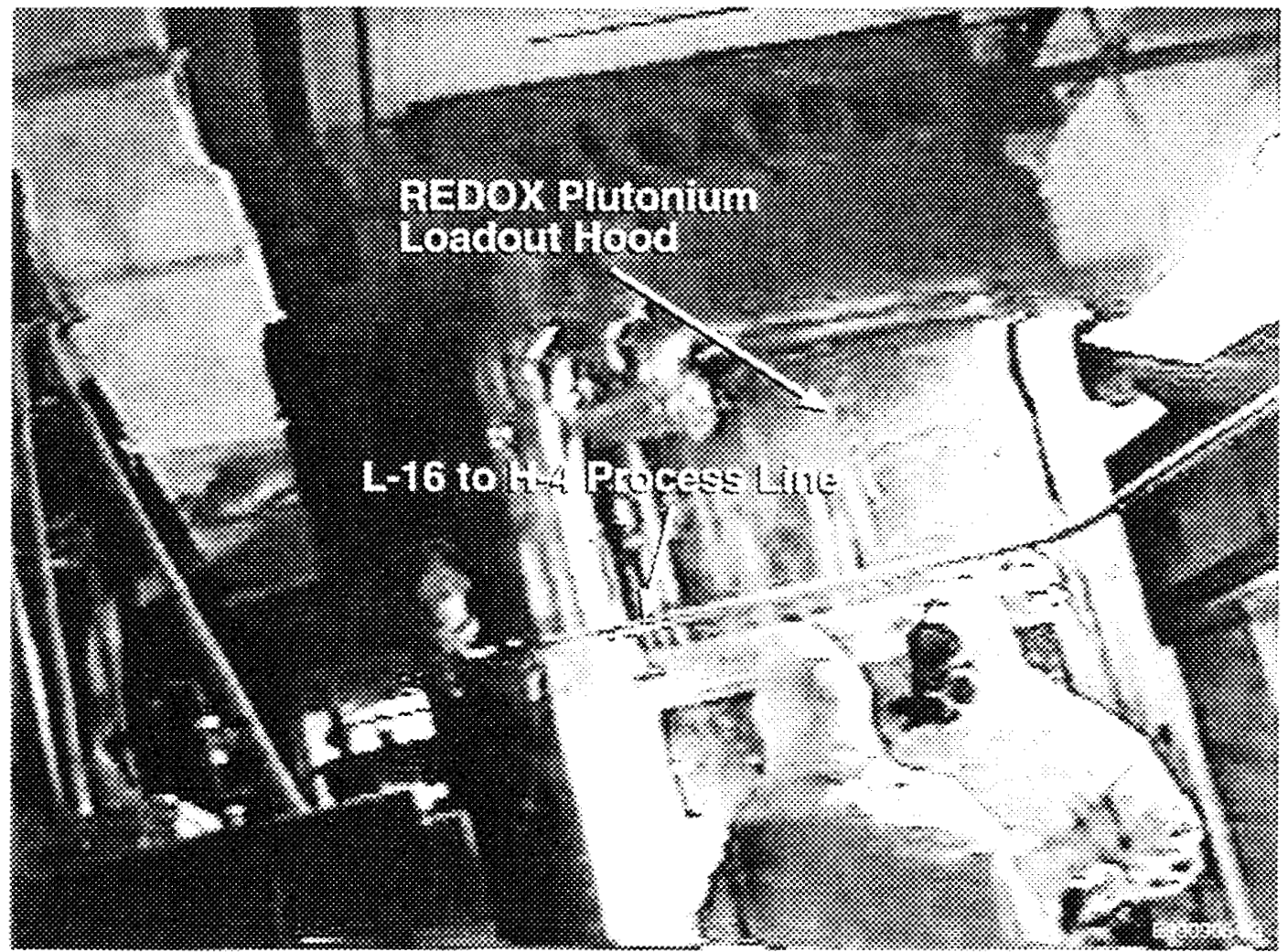

Figure 5. View Towards the 146 Sampler Box.

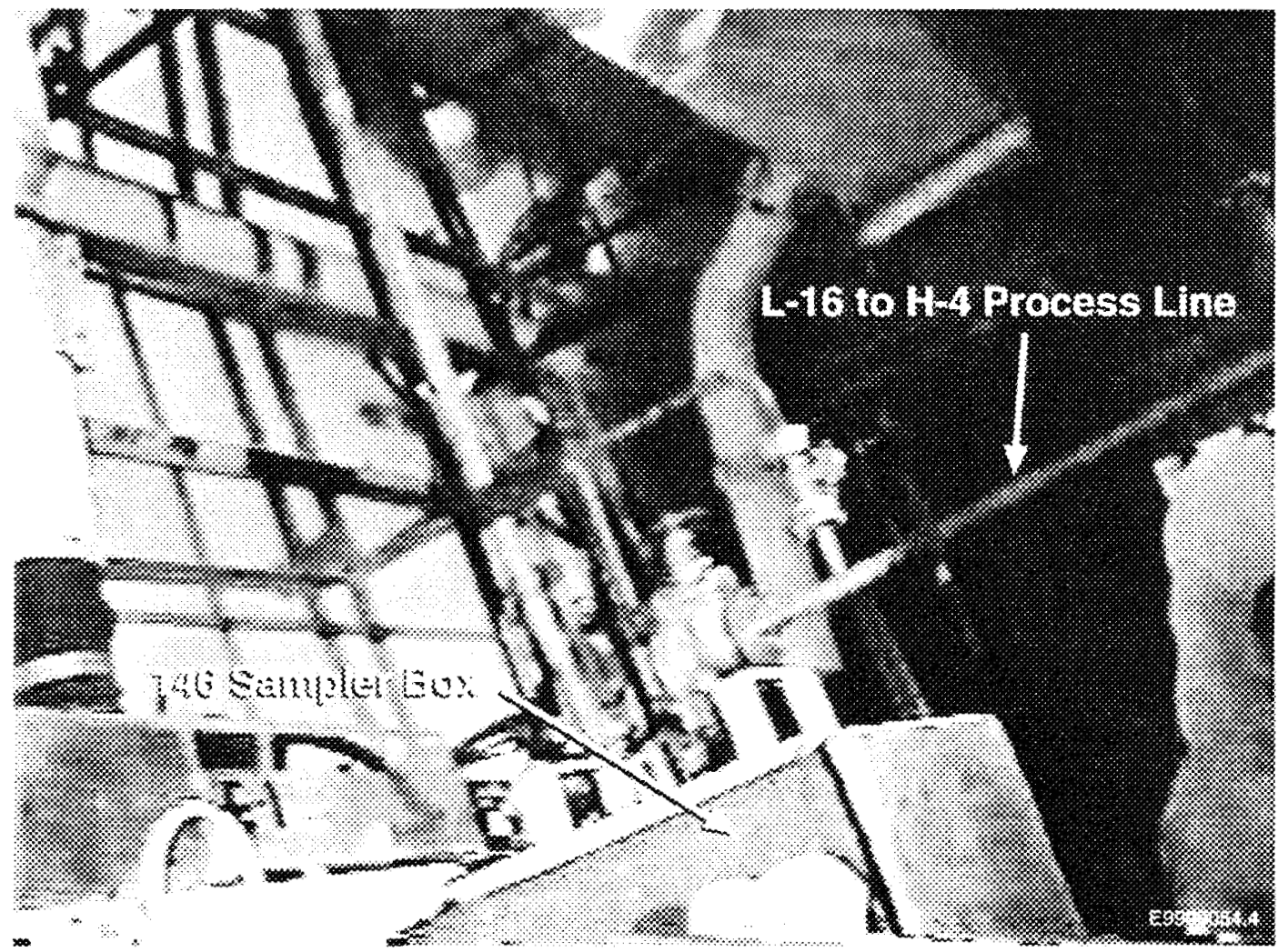


The floor of thie hood area was built to accommodate several large process vessels. On the base

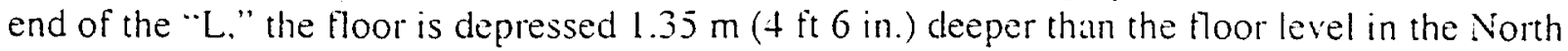
Sample Gallery and forms what is called the pit.

The E-16 preconcentrator and E-17 concentrator are located in this depression. A $15.2-\mathrm{cm}$ (6-in.) cubical sump, equipped with a vacuum transfer jet, is located at the northwest comer of this depression. The sump also received drain overflow from the 233-S pipe trenches that have all been deactivated, isolated, and cut.

The major vessels located inside the hood that were used to concentrate plutonium nitrate solutions have all been isolated and are described in Table 1. A detailed description of the REDOX Plutonium Loadout Hood is contained in the Sampling and Analysis Plan (SAP) (DOE-RL 1998). A number of pipes connect the vessels or provide access from utility services such as the steam, vacuum transfer, or cooling water systems.

Table 1. Major Plutonium Loadout Hood Process Vessels.

\begin{tabular}{|c|c|}
\hline Vessel Designation" & Vessel Use \\
\hline E-16. Preconcentrator and Tower & $\begin{array}{l}\text { First-step concentration of plutonium nitrate solution } \\
\text { from E-cell }\end{array}$ \\
\hline E-15. Preconcentrator Condenser & Condense E- 16 vapors \\
\hline E-1 H, Preconcentrator Condenser Receiver Tank & $\begin{array}{l}\text { Receives condensed E- } 16 \text { vapors from the } \\
\text { E-15 condenser }\end{array}$ \\
\hline E-17. Concentrator and Tower & $\begin{array}{l}\text { Second-step concentration of plutonium nitrate } \\
\text { solution from E-16 for loadout to the product remosal } \\
\text { cans }\end{array}$ \\
\hline E-18. Plutonium Concentrator Condenser & Condense E-17 vapors \\
\hline $\begin{array}{l}\text { E-19. Plutonium Concentrate Condenser Receiver } \\
\text { Tank }\end{array}$ & Collect E- 15 condensed E-17 vapors \\
\hline E-21, Plutonium Transfer Trap Tank & $\begin{array}{l}\text { Collect vacuum transfer plutonium nitrate solutions } \\
\text { for rework }\end{array}$ \\
\hline
\end{tabular}

The hood section that contained the equipment to fill the product removal cans was disassembled and moved to the 233-S Facility in 1955

\subsection{BACKGROUND OF PLUTONIUM LOADOUT HOOD AND EXTENT OF CONTAMINATION}

In 1995 , a concerted effort between BHI and RL was performed on the REDOX Facility to upgrade the existing electrical system, deactivate three secondary exhaust fans, install the remote monitoring system, and decontaminate the Sample Galleries. These tasks were performed to extend the surveillance frequency from daily to quarterly entries, and reduce the risks to personnel and the environment. The activities accomplished in the decontamination efforts in the North Sample Gallery included removal of loose contamination, removal of excess equipment and supplies, and sealing of the sampler boxes that were originally used in support of plant operations from 1952 to 1969. An isolation wall (false wall) was also constructed at 
Section D of the North Sample Gallery to isolate the alpha contamination that had historically been found adjacent to the Plutonium Loadout Hood. During the following investigation and decontamination, the 146 Sampler Box located directly behind the east end of the Plutonium Loadout Hood was discovered to be highly contaminated with loose alpha from an apparent leak from a valve on the L- 16 to H-4 transfer line. A criticality evaluation of the 146 Sampler Box was conducted and numerous briefings with the RL Assistant Manager for Environmental Management were held. In addition, an nondestructive analysis of the line and Plutonium Loadout Hood was performed to define the quantity and type of fissile malterial contained within the hood and adjacent lines. Information from this investigation recommended that BHI pursue a characterization of the hood.

The initial-phased characterization of the REDOX Plutonium Loadout Hood was conducted in accordance with the requirements of BHI Field Support Work Package No. 199S0325002, 202-S Plutonium Loadout Hood Sampling. Prior to initiating work, a readiness assessment was conducted and the successful completion is documented in the Readiness Assessment Report for the REDOX Plutonium Loadout Hood (BHI 1998b). Contamination levels are presented in Tables 2, 3, and 4 .

Because it was expected that the levels of loose alpha surface contamination greater than $1 \times 10^{6}$ $\mathrm{dpm} / 100 \mathrm{~cm}^{2}$, all access into the Plutonium Loadout Hood required the use of glovebags as the engineered barrier. The hood was maintained at a slightly negative pressure relative to the North Sample Gallery, thus ensuring that sampling personnel were physically isolated from the alpha inventory contained within the hood. The sample analysis was performed by the 222-S Laboratory in accordance with the Letter of Instruction for the Sample Analysis of the Reduction Oxidution Facility 9202-S) Plutonitum Loctout Hood (BHI 199Sa). A discussion of the sample collection activities and laboratory analysis results is provided in Interim Characterization Report for the REDOX Plutonium Loadout Hood (BHI 1999), Sections 4.I and 4.2, respectively. A sample of the L-16 Leak Area, Sample Box 146 exterior to the hood was taken. The following tables document the results of this characterization.

Table 2. Plutonium Loadout Hood Sump Sludge Multiphase Sample Results. (3 Pages)

\begin{tabular}{|c|c|c|c|}
\hline \multicolumn{3}{|c|}{ HEIS Sample Number B0PC23 } & \\
\hline Analyte & Liquid Phase & & \\
\hline Gross Alpha & $2.39 \mathrm{E}+01$ & $6.91 \mathrm{E}+01 \mu \mathrm{Ci} / \mathrm{g}$ & .. \\
\hline Gross Beta & $4.70 \mathrm{E}+00 \mu \mathrm{Ci} / \mathrm{mL}$ & $7.49 \mathrm{E}+00 \mu \mathrm{Ci} / \mathrm{g}$ & .. \\
\hline Strontium-90 & $2.92 \mathrm{E}-04 \quad \mu \mathrm{Ci} / \mathrm{mL}$ & $3.47 \mathrm{E}-04 \mu \mathrm{Ci} / \mathrm{g} \mathrm{J}$ & -. \\
\hline Cobalt-60 & $9.40 \mathrm{E}-06 \mu \mathrm{Ci} / \mathrm{mL} \mathrm{U}$ & $2.61 \mathrm{E}-04 \mu \mathrm{Ci} / \mathrm{g} \mathrm{U}$ & -. \\
\hline Antimony-125 & $4.18 \mathrm{E}-05 \mu \mathrm{Ci} / \mathrm{mL} \quad \mathrm{U}$ & $6.88 \mathrm{E}-04 \mu \mathrm{Ci} / \mathrm{g} \mathrm{U}$ & -. \\
\hline Cesium-134 & $9.75 \mathrm{E}-06 \mu \mathrm{Ci} / \mathrm{mL} \quad \mathrm{U}$ & $2.24 \mathrm{E}-04 \mu \mathrm{Ci} / \mathrm{g} \mathrm{U}$ &.- \\
\hline Cesium-137 & $1.38 \mathrm{E}-03 \mu \mathrm{Ci} / \mathrm{mL}$ & 2.82E-03 $\mu \mathrm{Ci} / \mathrm{g}$ & - \\
\hline Europium-152 & $1.42 \mathrm{E}-04 \mu \mathrm{Ci} / \mathrm{mL} \quad U$ & $5.97 \mathrm{E}-04 \mu \mathrm{Ci} / \mathrm{g} \mathrm{U}$ & .. \\
\hline Europium-154 & $2.49 \mathrm{E}-05 \quad \mu \mathrm{Ci} / \mathrm{mL} \quad \mathrm{U}$ & $8.11 \mathrm{E}-04 \mu \mathrm{Ci} / \mathrm{g} \mathrm{U}$ & -. \\
\hline 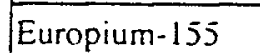 & $4.54 \mathrm{E}-04 \mu \mathrm{Ci} / \mathrm{mL} \quad U$ & $5.93 \mathrm{E}-04 \mu \mathrm{Ci} / \mathrm{g} \mathrm{U}$ & .. \\
\hline
\end{tabular}


Table 2. Plutonium Loadout Hood Sump Sludge Multiphase Sample Results. (3 Pages)

\begin{tabular}{|c|c|c|c|c|}
\hline \multicolumn{5}{|c|}{ HEIS Sample Number BoPC23 } \\
\hline \multirow{2}{*}{\begin{tabular}{r|} 
Analyte \\
Radium-226
\end{tabular}} & Liquid Phase & \multicolumn{3}{|c|}{ Solid Phase } \\
\hline & $3.73 \mathrm{E} \cdot 0+\mu \mathrm{Ci} / \mathrm{mL} \mathrm{U}$ & $5 .+3 \mathrm{E}-03 \mu \mathrm{Ci} / \mathrm{g} \mathrm{U}$ & & -. \\
\hline Actinium-228 & 3.90E-05 $\mu \mathrm{Ci} / \mathrm{mL} \quad U$ & $1 .+4 \mathrm{E}-03 \mu \mathrm{Ci} / \mathrm{g} \mathrm{U}$ & & -- \\
\hline Americium-24l(GEA) & $1.24 \mathrm{E}+01 \mu \mathrm{Ci} / \mathrm{mL}$ & $5.93 \mathrm{E}+00 \mu \mathrm{Ci} / \mathrm{g}$ & & -- \\
\hline Neptunium-237 & $1.84 \mathrm{E}-0+4 \mathrm{Ci} / \mathrm{mL} \quad \mathrm{U}$ & $2.20 \mathrm{E}-02 \mu \mathrm{Ci} / \mathrm{g}$ & & -- \\
\hline Plutonium-23S & $7.67 \mathrm{E}-0 \mathrm{l} \quad \mu \mathrm{Ci} / \mathrm{mL}, U$ & $3.40 \mathrm{E}+00 \mu \mathrm{Ci} / g \mathrm{U}$ & & -. \\
\hline Plutonium-239/240 & $1.29 \mathrm{E}+01 \mu \mathrm{Ci} / \mathrm{mL}$ & $7.7 \mathrm{LE}+01 \mu \mathrm{Ci} / \mathrm{g}$ & & -- \\
\hline Americium-2+1 & $1.14 \mathrm{E}+01 \mu \mathrm{Ci} / \mathrm{mL}$ & $1.02 \mathrm{E}+01 \mu \mathrm{Ci} / \mathrm{g}$ & & -- \\
\hline Curium-243/244 & $9.28 \mathrm{E}-01 \mu \mathrm{Ci} / \mathrm{mL} \mathrm{U}$ & $1.07 \mathrm{E}+00 \mu \mathrm{Ci} / \mathrm{g} \mathrm{U}$ & &.. \\
\hline Silver & $5.10 \mathrm{E}+00 \mu \mathrm{g} / \mathrm{mL} \quad \mathrm{U}$ & - & TCLP Ag & $1.67 \mathrm{E}-01 \mu \mathrm{g} / \mathrm{mL} \quad \mathrm{U}$ \\
\hline Arsenic & $5.10 \mathrm{E}+01 \mu \mathrm{g} / \mathrm{mL} \quad \mathrm{U}$ & - & TCLP As & $1.67 \mathrm{E}+00 \mu \mathrm{g} / \mathrm{mL} \quad U$ \\
\hline Barium & $2.55 \mathrm{E}+01 \quad \mu \mathrm{g} / \mathrm{mL} \quad \mathrm{U}$ & -. & TCLP Bil & $\$ .3 .3 \mathrm{E}-01 \mu \mathrm{g} / \mathrm{mL} \quad \mathrm{U}$ \\
\hline Cadmium & $2 .+4 \mathrm{E}+02 \quad \mu g / \mathrm{mL}$ & $1 .+7 \mathrm{E}+02 \mu \mathrm{g} / \mathrm{g}$ & TCLPCd & $4.32 \mathrm{E}+00 \mu \mathrm{g} / \mathrm{mL}$ \\
\hline Chromium & $2.33 \mathrm{E}+0+\mu \mathrm{g} / \mathrm{mL}$ & $1.63 \mathrm{E}+04 \mu \mathrm{g} / \mathrm{g}$ & TCLPCr & $+.22 \mathrm{E}+02 \mu \mathrm{g} / \mathrm{mL} \mathrm{J}$ \\
\hline Iron & $5.01 \mathrm{E}+02 \mu \mathrm{g} / \mathrm{mL}$ & $2.29 \mathrm{E}+0+\mu g / \mathrm{g}$ & & -. \\
\hline Nickel & $3.86 \mathrm{E}+02 \mu \mathrm{g} / \mathrm{mL}$ & $2.52 \mathrm{E}+02 \mu \mathrm{g} / \mathrm{g}$ & & -- \\
\hline Lead & $5.10 \mathrm{E}+01 \mu \mathrm{g} / \mathrm{mL} \quad U$ & $4.15 \mathrm{E}+01 \mu \mathrm{g} / \mathrm{s} \mathrm{J}$ & TCLP Pb & $1.67 \mathrm{E}+00 \mu \mathrm{g} / \mathrm{mL} \quad U$ \\
\hline Selenium & $5.10 \mathrm{E}+01 \quad \mu \mathrm{g} / \mathrm{mL} \quad \mathrm{U}$ & $\cdots$ & TCLP Se & $1.67 \mathrm{E}+00 \mu \mathrm{g} / \mathrm{mL} \quad \mathrm{U}$ \\
\hline Mercury & $1 .+6 \mathrm{E}+02 \mu \mathrm{g} / \mathrm{mL}$ & $1.19 \mathrm{E}+02 \mu \mathrm{g} / \mathrm{g}$ & TCLPHg & $5.31 \mathrm{E}+00 \mu \mathrm{g} / \mathrm{mL} \mathrm{J}$ \\
\hline Fuoride & $2.03 \mathrm{E}+02 \mu \mathrm{g} / \mathrm{mL} \quad \mathrm{J}$ & $1.71 \mathrm{E}+02 \mu \mathrm{g} / \mathrm{J} J$ & & .. \\
\hline Chloride & $4.68 \mathrm{E}+03 \mu \mathrm{g} / \mathrm{mL}$ & $3.61 \mathrm{E}+03 \mu \mathrm{g} / \mathrm{g}$ & & -. \\
\hline Nitrite & $1.10 \mathrm{E}+03 \mu \mathrm{g} / \mathrm{mL} \quad \mathrm{U}$ & $8.73 \mathrm{E}+02 \mu \mathrm{g} / \mathrm{g} \quad \mathrm{U}$ & & $\cdots$ \\
\hline Nitrate & $4.44 \mathrm{E}+05 \mu \mathrm{g} / \mathrm{mL}$ & $3.53 \mathrm{E}+05 \mu \mathrm{g} / \mathrm{g}$ & & -. \\
\hline Phosphate & $1.22 \mathrm{E}+03 \mu g / \mathrm{mL} \quad \mathrm{U}$ & $9.70 \mathrm{E}+02 \mu \mathrm{g} / \mathrm{g} \quad \mathrm{U}$ & & -. \\
\hline Sulfate & $5.60 \mathrm{E}+0+\mu \mathrm{g} / \mathrm{mL}$ & $7.83 \mathrm{E}+04 \mu \mathrm{g} / \mathrm{g}$ & & -. \\
\hline Oxalate & $1.98 \mathrm{E}+03 \mu \mathrm{g} / \mathrm{mL} \quad \mathrm{J}$ & $1.37 \mathrm{E}+03 \mu \mathrm{g} / \mathrm{g} \quad J$ & & -. \\
\hline Aroclor -1016 & $6.00 \mathrm{E}-02 \mu \mathrm{g} / \mathrm{mL} \quad \mathrm{UJ}$ & $3.30 \mathrm{E}-01 \mu \mathrm{g} / \mathrm{g} . U J$ & & -- \\
\hline Aroclor -1221 & $6.00 \mathrm{E}-02 \mu \mathrm{g} / \mathrm{mL} \quad \mathrm{UJ}$ & $3.30 \mathrm{E}-01 \mu \mathrm{g} / \mathrm{g} \quad \mathrm{UJ}$ & & -- \\
\hline Aroclor -1232 & $6.00 \mathrm{E}-02 \mu \mathrm{g} / \mathrm{mL} \quad \mathrm{UJ}$ & $3.30 \mathrm{E}-01 \mu \mathrm{g} / \mathrm{g} \quad \mathrm{UJ}$ & & $-\cdot$ \\
\hline Aroclor -1242 & $6.00 \mathrm{E}-02 \mu \mathrm{g} / \mathrm{mL} \quad \mathrm{UJ}$ & $3.30 \mathrm{E}-01 \mu \mathrm{g} / \mathrm{g} \quad \mathrm{UJ}$ & & -. \\
\hline Aroclor -1248 & 6.00E-02 $\mu \mathrm{g} / \mathrm{mL} \quad \mathrm{UJ}$ & $3.30 \mathrm{E}-0 \mathrm{l} \quad \mu \mathrm{g} / \mathrm{g} \quad \mathrm{UJ}$ & & -- \\
\hline Aroclor -1254 & $5.71 \mathrm{E}-02 \mu \mathrm{g} / \mathrm{mL} \quad \mathrm{J}$ & $2.21 \mathrm{E}-01 \mu \mathrm{g} / \mathrm{g} \quad \mathrm{J}$ & & - \\
\hline Aroclor -1260 & $6.00 \mathrm{E}-02 \mu \mathrm{g} / \mathrm{mL} \quad \mathrm{UJ}$ & $3.30 \mathrm{E}-01 \mu \mathrm{g} / \mathrm{g} \quad \mathrm{UJ}$ & & .. \\
\hline Hexone & $2.56 \mathrm{E}+00 \mu \mathrm{g} / \mathrm{mL} \quad \mathrm{UJ}$ & $2.20 \mathrm{E}-02 \mu \mathrm{g} / \mathrm{g} \quad$ UJ & & - \\
\hline Asbestos & -- & $\begin{array}{l}\text { No solids remained } \mathrm{ft} \\
\text { analysis. }\end{array}$ & m diges & no asbestos-like material for \\
\hline Resin bead & -. & $\begin{array}{l}\text { No solids remained } \\
\text { for analysis. }\end{array}$ & m digest & no resin bead-like material \\
\hline
\end{tabular}


BHI-01 299

Rev. 0

Table 2. Plutonium Loadout Hood Sump Sludge Multiphase Sample Results. (3 Pages)

\begin{tabular}{|c|c|c|c|c|c|}
\hline \multicolumn{6}{|c|}{ HEIS Sample Number BOPC23 } \\
\hline Analyte & \multicolumn{2}{|c|}{ Liquid Phase } & & & \multirow[t]{2}{*}{ Solid Phase } \\
\hline Density & 1.53 & $\mathrm{G} / \mathrm{mL}$ & 1.55 & $y / \mathrm{mL}$ & \\
\hline Vol \% & 74.3 & $\pi$ & 25.7 & 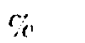 & \\
\hline
\end{tabular}

$\mathrm{U}=$ Nondetectable

$\mathrm{J}=$ Estimated

Table 3. Tank E-17 Process Piping Leach

Sample Results. (2 Pages)

\begin{tabular}{|c|c|c|}
\hline \multicolumn{3}{|c|}{ IIEIS Sample Number BOPC22 } \\
\hline Analyte & Liquid Pha & \\
\hline Grosis alpha & $2.15 \mathrm{E}-01 \mu \mathrm{Ci} / \mathrm{mL}$ & \\
\hline Gross beta & $7 .+4 \mathrm{E}-0.3 \mathrm{Ci} / \mathrm{mL}$ & \\
\hline Stronium-90 & $9.65 \mathrm{E}-05 \mu \mathrm{Ci} / \mathrm{mL}$ & \\
\hline Cobait -60 & $7.06 \mathrm{E}-07 \mu \mathrm{Ci} / \mathrm{mL}$ & $\mathrm{U}$ \\
\hline Antimony-125 & $1.90 \mathrm{E}-06 \mu \mathrm{Ci} / \mathrm{mL}$ & $\mathrm{U}$ \\
\hline Cesium-134 & $5.92 \mathrm{E}-07 \mu \mathrm{Ci} / \mathrm{mL}$ & $U$ \\
\hline Cesium-137 & $1.61 \mathrm{E}-06 \mu \mathrm{Ci} / \mathrm{mL}$ & $\mathrm{U}$ \\
\hline Europium-152 & $1.79 \mathrm{E}-06 \mu \mathrm{Ci} / \mathrm{mL}$ & $\mathrm{U}$ \\
\hline Europium-154 & $1.53 \mathrm{E}-06 \mu \mathrm{Ci} / \mathrm{mL}$ & U \\
\hline Europium-155 & $2.80 \mathrm{E}-06 \mu \mathrm{Ci} / \mathrm{mL}$ & $\mathrm{U}$ \\
\hline Radium-220 & $1.26 \mathrm{E}-05 \mu \mathrm{Ci} / \mathrm{mL}$ & $\mathrm{U}$ \\
\hline Actinium-22s & $3.45 \mathrm{E}-06 \mu \mathrm{Ci} / \mathrm{mL}$ & $\mathrm{U}$ \\
\hline Americium-2+1 (GEA) & $1.05 \mathrm{E}-02 \mu \mathrm{Ci} / \mathrm{mL}$ & \\
\hline Neptunium-237 & $1.66 \mathrm{E}-05 \mu \mathrm{Ci} / \mathrm{mL}$ & $\mathrm{U}$ \\
\hline Plutonium-238 & $1.08 \mathrm{E}-02 \mu \mathrm{Ci} / \mathrm{mL}$ & U \\
\hline Plutonium-239/2 40 & $2.65 \mathrm{E}-01 \mu \mathrm{Ci} / \mathrm{mL}$ & \\
\hline Americium-2+1 & $1.03 \mathrm{E}-02 \mu \mathrm{Ci} / \mathrm{mL}$ & \\
\hline Curium-243/2+4 & $1.32 \mathrm{E}-03 \mu \mathrm{Ci} / \mathrm{mL}$ & $\mathrm{U}$ \\
\hline Cadmium & $5.00 \mathrm{E}-03 \mu \mathrm{g} / \mathrm{mL} \mathrm{U}$ & \\
\hline Chromium & $9.61 \mathrm{E}+00 \mu \mathrm{g} / \mathrm{mLU}$ & \\
\hline Iron & $4.28 \mathrm{E}+01 \mu \mathrm{g} / \mathrm{mLU}$ & \\
\hline Nickel & $1.25 \mathrm{E}+01 \mu \mathrm{g} / \mathrm{mLU}$ & \\
\hline Lead & $1.00 \mathrm{E}-01 \mu \mathrm{g} / \mathrm{mL} \mathrm{U}$ & \\
\hline Mercury & $1.00 \mathrm{E}-02 \mu \mathrm{g} / \mathrm{mL} \mathrm{U}$ & \\
\hline Total Leachate Volume & $19 \mathrm{smL}$ & \\
\hline
\end{tabular}

$\mathrm{U}=$ nondetectable

$\mathrm{J}=$ estimated 
BHI-01299

Rev. 0

Table 4. Plutonium Loadout Hood Technical Smear Sample Results.

\begin{tabular}{|c|c|c|c|c|c|c|c|}
\hline \multirow[t]{2}{*}{$\begin{array}{l}\text { Smear Location: } \\
\text { HEIS Sample \# }\end{array}$} & \multicolumn{2}{|c|}{$\begin{array}{l}\text { Tank E19 } \\
\text { B0PC2t }\end{array}$} & $\begin{array}{l}\text { Tank E16 } \\
\text { B0PC25 }\end{array}$ & $\begin{array}{l}\text { Tank E21 } \\
\text { B0PC26 }\end{array}$ & $\begin{array}{c}\text { Hood Floor } \\
\text { Between E19 } \\
\text { and E12 } \\
\text { BoPC27 }\end{array}$ & $\begin{array}{l}\text { Tank E17 } \\
\text { B0PC2S }\end{array}$ & \multirow[t]{2}{*}{$\begin{array}{c}\text { L-16 Leak } \\
\text { Area } \\
\text { Sample Box } \\
146 \\
\text { B0PK78 } \\
\end{array}$} \\
\hline & & & & $\mu \mathrm{Ci}$ per & r sample & & \\
\hline Gross alpha & $2.3 S E+00$ & 1 & $2.98 \mathrm{E}+00$ & $3.66 \mathrm{E}-01$ & $6.2+E-02$ & 6.78 E-01 & $5.3+E+01$ \\
\hline Gross beta & $2.39 \mathrm{E}-01$ & $\mathrm{~J}$ & $2.69 \mathrm{E}-01 \mathrm{~J}$ & $3.45 \mathrm{E}-02 \quad \mathrm{~J}$ & $5.4+E-03 \quad J$ & 4.82 E-02 & $4.29 E+00$ \\
\hline Strontium-90 & $2.43 \mathrm{E} \cdot 05$ & $\mathrm{~J}$ & $1.98 \mathrm{E}-05 \mathrm{~J}$ & $7.17 \mathrm{E}-06 \quad U$ & $1.11 \mathrm{E}-05 \mathrm{U}$ & $6.30 \mathrm{E}-06 \mathrm{U}$ & $2.17 \mathrm{E}-05$ \\
\hline Cobalt -60 & $2.00 \mathrm{E}-04$ & $\mathrm{U}$ & 1.S6E.04 U & $6.4+E-05 \quad U$ & 5.87 E-05 U & $6.60 \mathrm{E}-05 \mathrm{U}$ & $6.47 \mathrm{E}-05 \quad U$ \\
\hline Antimony 125 & $6.11 E-04$ & $\mathrm{U}$ & $6.31 E-04 \quad U$ & 1.71 E-04 U & 1.61 E-0t U & 1.65 E-04 U & 1.69 E-04 U \\
\hline Cesium-134 & $2.0+E-04$ & $U$ & $2.10 \mathrm{E}-04 \mathrm{U}$ & 5.42 E-05 U & $5 .+7$ E-05 U & 5.42 E. $05 \quad U$ & $5.52 \mathrm{E} .05 \mathrm{U}$ \\
\hline Cesium-137 & 2.67 E-0t & $U$ & $2.70 \mathrm{E}-0+\mathrm{U}$ & $7.91 \mathrm{E}-05 \mathrm{U}$ & $7.4+E-05 \quad U$ & 7.56 E-0.5 U & $7.5+E-0.5 \quad U$ \\
\hline Europium-152 & $5.53 \mathrm{E}-04$ & $\mathrm{U}$ & $5.35 \mathrm{E}-04 \mathrm{U}$ & 1.32 E-0. U & $1.33 \mathrm{E}-04 \mathrm{U}$ & $1.35 \mathrm{E}-04 \mathrm{U}$ & $1.5+E-0+U$ \\
\hline Europium-154 & $6.2 \mathrm{SE}-0 t$ & $U$ & $0.1+E-04 \quad U$ & $2.04 \mathrm{E}-0+\mathrm{U}$ & 1.87 E-04 U & 2.05 E-04 U & $1.9 S \mathrm{E} .04 \mathrm{U}$ \\
\hline Europium-155 & $4.38 \mathrm{E}-04$ & $U$ & $4.47 \mathrm{E}-04 \quad U$ & 1.00 E-04 U & $9.62 E .05 \quad U$ & $9.81 \mathrm{E}-05 \mathrm{U}$ & 1.9S E-04 U \\
\hline Radium-226 & $4.74 \mathrm{E}-03$ & $\mathrm{U}$ & $+.77 \mathrm{E}-03 \quad U$ & $1.31 \mathrm{E}-0.3 \mathrm{U}$ & 1.2SE.03 U & $1.29 \mathrm{E}-03 \mathrm{U}$ & $1.33 E-03 U$ \\
\hline Actinium-22S & $1.19 \mathrm{E}-03$ & $\mathrm{U}$ & $1.20 \mathrm{E}-03 \quad U$ & 3.61 E-0t U & $3.5 S \mathrm{~S}-0+\mathrm{U}$ & $3.55 \mathrm{E}-04 \mathrm{U}$ & $3.57 \mathrm{E}-0+\mathrm{U}$ \\
\hline $\begin{array}{l}\text { Americium-2+1 } \\
\text { (GEA) }\end{array}$ & $4.01 \mathrm{E}-01$ & & $+13 \mathrm{E}-01$ & $5.35 \mathrm{E}-02$ & $9.10 \mathrm{E} \cdot 03$ & 9.10 E-02 & $5.25 E+00$ \\
\hline Nepcunium-237 & $1.30 \mathrm{E}-03$ & $\mathrm{U}$ & $1.83 E .03 U$ & $1.68 \mathrm{E}-03 \mathrm{U}$ & 9.37 E-04 U & $1.19 E-03 U$ & 1.87 E-03 U \\
\hline Plutonium-238 & 1.37 E-01 & $\mathrm{U}$ & $1.76 \mathrm{E}-01 \mathrm{U}$ & $2.40 \mathrm{E}-02 \mathrm{U}$ & $4.6+E-03 U$ & $4.05 \mathrm{E} .02 \mathrm{U}$ & $5.65 \mathrm{E}+00 \mathrm{~J}$ \\
\hline Plutonium-239/240 & $2.66 E+00$ & & $3.2+E+00$ & $3.98 \mathrm{E}-01$ & 6.52 E-02 & 7.19 E-01 & $3.58 \mathrm{E}+01$ \\
\hline Americium-24l & 3.68 E-01 & & 3.87 E.01 & $6.35 \mathrm{E}-02$ & 1.02E-02 & $1.09 \mathrm{E}-0 \mathrm{I}$ & $2 .+1 E+01$ \\
\hline Curium-243/244 & 7.06 E-02 & $U$ & $6.8+E-02 \quad U$ & $1.13 E-02 \quad U$ & $1.90 \mathrm{E} .03 \mathrm{U}$ & $1.3+E-02 \quad U$ & $3.4 S E+00 U$ \\
\hline
\end{tabular}

Ficld instrument readings (DPM alpha) tikin from the hood:

$\begin{array}{llllll}6.00 E+04 \text { top } & 5.20 E+06 \text { top } & 1.35 E+05 \text { top } & 4.50 E+05 & 6.00 E+05 \text { top } & 3.00 E+06 \\ 6.00 E+04 \text { side } & 2.70 E+05 \text { side } & 1.80 E+05 \text { side } & 3.60 E+05 & 3.00 E+05 \text { side } \\ & & & 8.70 E+05 & \\ & & & 4.50 E+05\end{array}$

Contaminants found within the Plutonium Loadout Hood interior surfaces, sump, technical smears, and tank E-17 process piping leachate include the following (per BHI 1999):

- strotium-90

- cobalt-60

$\therefore \quad$ antimony-125

- cesium-134

- cesium-137

- europium-152

- cadmium

- nickel

- mercury

- nitrite

- sulfate
- europium-154

- europium-155

- radium-226

- actinium-228

- americium-241

- neptunium-237

- chromium

- lead

- fluoride

- nitrate

- oxalate
- plutonium-239/240

- americium-241

- curium-243/244

- silver

- arsenic

- barium

- iron

- selenium

- chloride

- phosphate

- aroclor-1016 

- aroclor-1221
- aroclor-1248
- aroclor-1232
- aroclor-1254

Quantities detected can be reviewed in BHI (1999).
- aroclor-1242

- aroclr-1260

- hexone.

This alternative study is the next progiession in the RL decision process that continues the efforts stated in 1995, to ensure that the ERC continues to definc, evaluate, and mitigate the identified risks that are posed by these plants and the inventories that are contained within them. The Plutonium Loadout Hood is the second in a series of plutonium-containing structures that need to be evaluated and have an action plan established that will minimize the effects of this inventory on personnel and the environment.

\subsection{SAMPLE COLLECTION}

This section provides a summary of the actual samples collected with their associated HEIS identifying number. In addition, quality-controlled (QC)-required samples used to assess possible cross-contamination of samples from the equipment used or cluring movement to the laboratory were collected using deionized water.

Samples consisted of one sample (two phases) recovered from the hood sump, one section of process line pipe, five technical smear samples taken from surfaces within the hood, and one technical smear sample taken from a suspected contaminated area outside of the hood. All samples were collected and packaged in accordance with Work Package 19980325002 and controlled as required from the point of origin to the analytical laboratory as required by BHI-EE-01, Envirommental lavestigations: Procedures, EIP 3.0, "Chain of Custody."

The radiological conditions within the Plutonium Loadout Hood are summarized in BHI (1999) and are consistent with initial planning and historical data. The removable alpha contamination ranged between $3 \times 10^{5} \mathrm{dpm} / 100 \mathrm{~cm}^{2}$ and $6.7 \times 10^{6} \mathrm{dpm} / 100 \mathrm{~cm}$ on top of the 146 sampler tank. It was determined that the sump contained a wet sludge rather than the expected dry sludge. In each case, the work package was revised to account for the change. A brief discussion of each case is provided in Sections 4.1.

\subsection{CONTAMINATION SPREAD POTENTIAL}

Radiological contamination has not been detected to have spread from the Plutonium Loadout Hood facility to adjoining areas within the REDOX Facility. Piping connecting the 233-S Facility to the Plutonium Loadout Hood has been cut, which further isolates the potential for contaminants from the Plutonium Hood facility spreading to other areas of the REDOX Facility.

The use of bio-indicators can be used to help determine the release of radiological contaminants. Uptake of radionuclide contaminants by the ecosystem is dependent upon the specific contaminants, soil chemistry, plant species, and animal or insect species. In general, radionuclides of a high atomic number are discriminated against by plant or animal uptake. Uranium and plutonium generally do not move readily through the food chain (due to low 
ecological mobility) and are highly poisonous to humans. Cesium-137 and strontium-90 are readily absorbed by plants and through the lood chain and are less poisonous to humans. The potential risk of Plutonium Loadout Hood contaminants being spread to the environment or to workers depends upon the continued integrity of the current containment and ventilation system.

\subsection{PUBLIC ACCESS AND LAND USE}

Public access to the 200 Area on the Hanford Site is currently restricted. The current land use consists of waste management and cleanup activities. For the purposes of conducting cleanup activities, the land areas have been grouped into operable units. An operable unit is an areal of land that contains similar types of facilities and waste sites. The REDOX Facility is in the 200-RO-3 Operable Unit and any selection of alternatives for the Plutonium Loadout Hood will not change this.

\subsection{SAFEGUARDS AND SECURITY}

Currently, the REDOX Facility is classified as a Hazard Category 2 nuclear facility. A letter requesting disposition of the remaining special nuclear material inventory as normal operating loss has been approved by RL (BHI 1995). If during S\&MI of the REDOX Facility, any item or container is found that may be suspected to contain special nuclear material, notification would be made to RL and BHI management.

During S\&M, the REDOX Facility and most of the ancillaries are unoccupied, locked, and/or seiled. A chain-link perimeter fence with locked access gattes deters physical access. Entry into the REDOX Facility fenced areas and buildings is limited to authorized personnel with proper training. Signs are posted accordingly throughout the facility identifying restricted access. The facility is entered only for S\&M activities. Access control for REDOX and other surplus facilities is described in BHI-FS-01, Field Support Administration. Section 1.1, "Access Control and Administration for ERC Facilities."

There are no intrusion alarms or routine security patrols within the perimeter fence of the REDOX Facility. Hanford Patrol continues to provide routine security patrols in the vicinity as part of their patrols throughout the 200 West Area. The Benton County Sheriff provides routine traffic patrol throughout the Hanford Site.

\section{$: \quad 4.5 \quad$ SEISMIC RISK}

Seismic studies prepared in support of the REDOX Facility Safety Analysis Report (Kerr 1998)

- focused on a relatively weak portion of the canyon structure. A narrow cross section of the wall that supports the canyon roof was found to be susceptible to a relatively low-energy seismic event $(0.054 \mathrm{~g}$ horizontal). The evaluations concluded that the canyon roof could fall into the canyon. Evaluations of the canyon deck concluded that the deck structures could survive the combined loads of an earthquake and drop off the roof structures and onto the deck. However, it was assumed that the north gallery structures of the 202-S Building (e.g., North Operating Gallery, North Pipe Gallery, and North Sample Gallery) would fail under the combined loads of 
the earthquake and drop of the canyon roof structures. In 1999, an additional seismic evaluation (Rajagopal 1999) of the north gallery structures was prepared because significant dose consequences were postulated from release of inventory of the Plutonium Loadout Hood that is located in the North Sample Gallery of the 202-S Building:

The seismic evaluation (Rajagopal 1999--see Appendix A) evaluated the potential impacts of an earthquake load of a design/evaluation basis earthquake of $0.20 \mathrm{~g}$ horizontal with a two-thirds simultaneous vertical load (DOE Order 5420.28). While damage from the earthquake was postulated, the damage to the North Sample Gallery and the Plutonium Loadout Hood was found to be relatively minor. Consequently, the estimated dose consequence of the REDOX Safety Analysis Report (Kerr 1998) that assumed a significant release from the Plutonium Loadout Hood was erroneously considered as a risk contributor of a relatively low-level earthquake as well as from a more significant design/evaluation basis earthquake. Therefore, it is concluded that inventory within the Plutonium Loadout Hood does not pose a significant release threat because of earthquakes. Engineering analysis has determined that no bracing of the floor holding the Plutonium Loadout Hood is required.

\subsection{PLUTONIUM LOADOUT HOOD INVENTORY}

Nondestructive analysis (NDA) of the Plutonium Loadout Hood was performed in late 1996 and early 1997. A report summarizing the NDA (BHI 1997) documented the estimated residual inventory within the Plutonium Loadout Hood and related components.

In 1999, sampling within the Plutonium Loadout Hood was pretormed to verify the radiological inventory that was documented in BHI (1997). Evaluation of the sample data (Gonsky 1999 to be reported in the Safely Evaluation for the REDOX Plutonium Loadout Hood currently in draft) concluded that the assumptions and conclusions of the NDA are reasonably accurate. Relatively minor amounts of plutonium reside in surface contamination of the interior surface of the hood enclosure, floor area of the hood, and the sump within the hood. The vast majority of the plutonium residual is within the piping and vessels of the Plutonium Loadout Hood especially, in the E-16 Pre-Concentrator and E-17 Concentrator. Table 5 summarizes the plutonium content of hood.

Table 5. Estimate Of Plutonium Holdup

\begin{tabular}{|c|c|c|c|}
\hline Component & $\begin{array}{c}\text { Plutonium* } \\
\text { (grams) }\end{array}$ & $\begin{array}{c}\text { Error factor } \\
\text { (percent/grams) }\end{array}$ & $\begin{array}{c}\text { Total } \\
\text { (grams) }\end{array}$ \\
\hline Loadout Hood Sump & 2.5 & $1.5 / 0.04$ & 2.54 \\
\hline Floor Area & 0.36 & 2.810 .01 & 0.37 \\
\hline E-16 Pre-Concentrator & 1450 & $10 / 145$ & 1595 \\
\hline E-17 Concentrator & 650 & $10 / 65$ & 715 \\
\hline $\begin{array}{c}\text { Pipe-trench drain line } \\
\text { (1-inch drain) }\end{array}$ & 2.0 & $45 / 0.9$ & 2.9 \\
\hline
\end{tabular}

* All plutonium is assumed to be plutonium-239. The lack of samples precludes accurate conclusions of isotopic distribution within the piping and vessels. 
The isotopic fractions within the piping and vessels of the Plutonium Loadout Hood have not been characterized with any statistical significance. One sample of the piping that led to the former product loadout vessel was taken. The results of that sample tend to support the assumptions of BHI (1997) (e.g., weapons-grade plutonium is assumed). The surface contamination in the sump, on the surfaces of the vessels, and on the floor within the Plutonium Loadout Hood does not appear to be of weapons-grade sources. It is likely that these contaminants are from the deactivation of connecting waste lines and systems that are outside of the Plutonium Loadout Hood.

\subsection{REMOVAL ACTIONS ALTERNATIVES}

The alternatives presented only apply to the Plutonium Loadout Hood and the L-16 to the H-t process line.

\subsection{CONTINUED SURVEILLANCE AND MAINTENANCE ACTION}

The no-action alternative consists of conducting routine inspections and radiological surveys at the Plutonium Loadout Hood. The inspections would be conducted to determine water infiltration into the hood, general condition of the hood, and routine smears of contaminants outside of the hood. Under this alternative, current S\&M activities will be taken to maintain the Plutonium Loadout Hood and to prevent release of contaminants or hazardous substances and do no other actions except in an emergency basis. The current hood and ventilation system prevents spread of contaminants and would continue to receive regular schedule maintenance and testing. The 296-S-2 stack would continue to have routine flow testing, quarterly filter changes on the stack pack or when work is done on the hood, and radiological emissions would be calculated as part of the Hanford Site radioactive emissions. There would be no action taken to remove the L-16 to H-4 2.54-cm- (1-in.-) line leading to Sampler Box 146 which has had "drips" from leaky flanges that has lead to posting of airbome contamination in the REDOX North Sample Gallery area.

\subsection{INTERIM STABILIZATION}

The stabilization altemative consists of spraying a fixative to the exterior surfaces of the hood to fix contaminants in place. A Lexan panel will then be removed and the interior of the hood sprayed with an approved acrylic fixative (such as Bartlett $\mathrm{TM}^{2}$ ) on all exposed surfaces. A glove bag that was used to fit over the Lexan opening for characterization of the hood could be used to spray the fixative. To prevent any disturbance of the contents in the sump during fixative spraying, only a hand-pump sprayer or low-volume airless sprayer would be used to prevent redisturbance of unfixed contamination. The L-16 to H-4 2.54-cm (1-in.-) line leading to the Sampler Box would be removed, flanges removed, and capped to prevent any further "drips". This would remove the current airborne potential within the REDOX North Sample gallery.

\footnotetext{
${ }^{2}$ Bartlett is a tradename of Polymeric Barrier Systems, Plymouth, Massachusetts.
} 
Since the hood sump is in the lowest depression of the hood and leads to piping to the REDOX Facility, any liquid (if present) currently in the sump would be removed if possible, or capped with a grout. The sump would be applied with a self-leveling cementitious grout mixture to fix contaminants and prevent no further moisture moving past the sump. Grouting of the sump in place with its contents or removal of the sump contents will require the removal of a Lexan panel.

The inventory release potential for the hood after stabilization will be recalculated using CAP-8SC and the results will be provided to the EPA and the Washington State Department of Health. The CAP-88C model is approved by the EPA to estimate unabated emissions to the air. If the results show that the release potential is minimal and regulatory approval is agreed upon, then the 296-S-2 stack can be deactivated, capped, and blanked. At this point, no continued maintenance of the stack will be required except for yearly inspections of the stack cap and damper to ensure their integrity.

Any hazardous substances generated would need to be identified as transuranic (TRU) or non-TRU mixed waste. Both TRU and non-TRU contaminated waste would also be designated as mixed waste and would need to be sent to the Hanford Site Central Waste Management Complex (CWMC).

\subsection{COMPLETE REMOVAL}

This alternative involves complete removal of the Plutonium Loadout Hood and all internal components and exhaust system independent of a final regulatory decision on the REDOX Facility. The L-16 to $\mathrm{H}-4$ line leading the 146 sampler box would also be removed. This option would require completion and approval by the lead regulatory agency (EPA) of an EE/CA as at decision document for this alternative. Waste shipments would be coordinated with the Environmental Restoration Disposal Facility planning personnel and EPA to avoid negatively impacting remedial actions at other sites in accordance with previously established milestones through the Hanford Federal Facility Agreement and Consent Order (Ecology et al. 1998).

The regulatory and approval process will be similar to the Process Hood removal planned for the 233-S Facility. The 233-S project provides an excellent experience base for this type of removal activity. The contamination levels are the same for the REDOX Plutonium Loadout Hood but the required work discipline and vigor is the same. A comprehensive safety analysis review will be required along with a extensive readiness review and approval by RL. In addition, an air monitoring plan would be required to ensure emissions from this action are estimated and documented to a level of $<0.1$ mrem per year to an estimated offsite individual.

Additionally, at least some of the waste and liquids generated from removal of the sump and process vessels would be TRU and hazardous waste designated materials. This waste would only have a storage option at CWMC with EPA approval. The EE/CA would also require non-TRU waste to have EPA approval to dispose of mixed waste components in accordance with the Environmental Restoration Disposal Facility Waste Acceptance Criteria (BHI 1998c). Currently, polychlorinated biphenols (PCB) are known to be present in paint and debris within the Plutonium Loadout Hood. Any other offsite facilities that could be utilized would require EPA approval. Waste shipments would be coordinated with ERDF planning personnel and EPA 
BHI-01299

Rev. 0

to a woid negatively impacting remedial actions at other sites in accordance with previously established milestones through the Tri-Party Agreement (Ecology et al. 199S).

\subsection{IDENTIFICATION OF STANDARDS AND REQUIREMENTS}

Applicable or relevant and appropriate requirements (ARAR) are standards, requirements, criteria, or limitations promulgated under federal or state environmental laws that must be met or waived for actions conducted under CERCLA. Only the substantive provisions of requirements that are ARAR must be met (or waived) for actions conducted entirely onsite (CERCLA Sec. $12 \mathrm{l}(\mathrm{d})(2)$ ). To be considered materials, there are nonpromulgated standards that may be reterenced to the extent necessary for the response action to be adequately protective of DOE orders, proposed regulations, and nonpromulgated regulatory guidance and interpretation.

The existing authorization basis documents for the REDOX facility to conduct current S\&M and interim stabilization alternative includes waste management standards, air emission control standards and permit, radiation control standards, and waste disposal standards. Other standards including worker protection standards, DOE orders, and historical protection of artifacts and resources must be followed.

\subsection{WASTE MANAGEMENT STANDARDS}

The Resource Conservation and Recovery Act of 1976 (RCRA) regulates managing and disposing of hazardous (and dangerous) waste. Authority for much of the federal RCRA program has been delegated to $W$ ashington State. Implementing state regulations contained in Hashington Administrative Code (WAC) 173-303 requires identification and appropriate management of dangerous wastes and dangerous components of mixed wastes, and establishes standards for treatment, storage, and disposal of these wastes. Federal RCRA requirements pertaining to hazardous wastes are identified in 40 CFR 260 through 270 . Federal and state RCRA requirements are applicable to any wastes managed (i.e., the physical disruption of waste residing in waste sites) as part of the stabilization alternative that meet the regulatory definition of hazardous (dangerous) or mixed waste. These regulations are applicable to all of the alternatives.

The most probable application of these requirements would be to the onsite storage of any newly containerized dangerous wastes within a waste site boundary. Pertinent standards for these storage activities are identified in WAC 173-303-630, and include requirements for waste container compatibility, container identification, container management, inspection of storage areas, segregation of incompatible wastes, and provision of secondary containment for containers holding liquid dangerous wastes.

WAC 173-304 requires identification and appropriate management of solid wastes. It is applicable to any solid waste that is generated as part of the stabilization altemative. Solid, dangerous, low-level, and/or mixed waste may be managed as waste undergoing stabilization. Actions proposed to manage such waste would be designed to satisfy waste management ARAR. Wastes that must be managed per these ARAR are those materials residing in waste sites that are 
physically disturbed during stabilization activities. All wastes would be evaluated and managed in compliance with the appropriate requirements. Prior to disposal, dangerous, low-level, or mixed wastes would be managed in a protective environment with filtered ventilation to prevent releases to the environment or exposure to workers.

It is anticipated that non-TRU waste managed during the removal option would satisfy the waste acceptance criteria for ERDF (BHI 199Sc). The ERDF is engineered to meet RCRA landfill performance standards under 10 CFR 61 for disposal of low-level and mixed wastes. Any TRU liquid or solid wastes are anticipated to be defined as having mixed waste characteristics and the only storage option available is through the Hanford Site CWMC with its acceptance criteria.

\subsection{AIR ENISSION CONTROL STANDARDS}

The Clean Air Act of 1955 regulates both toxic and radioactive airborne emissions. Under implementing regulations found in $40 \mathrm{CFR} 61$, Subpart $\mathrm{H}$, and WAC 246-247, radionuclide airborne emissions from all combined operations at the Hanford Site may not exceed 10 mrem per year to the offsite maximally exposed individual. WAC 246-247 requires verification of compliance, typically through periodic confirmatory air sampling. WAC 173-400 establishes requirements for controlling and preventing the emission of air contaminants, including dust. These regulations are applicable to all of the alternatives.

The radionuclide emission standards would apply to any fugitive, diffuse, and point-source air emissions of radionuclides generated under the stabilization or removal alternatives. If the potential exists for any nonzero radioactive emissions, best available radionuclide control technology would be required. If activities generate an increase of toxic air pollutants to the atmosphere above the small quantity emission rates, implementation of best available control technology for toxics would be required.

\subsection{PROTECTION STANDARDS}

Occupational Radiation Protection (10 CFR 835) establishes radiation protection standards, limits, and program requirements for protecting workers and visitors from ionizing radiation resulting from the conduct of DOE activities. It also requires that measures be taken to maintain radiation exposure as low as reasonably achievable. This regulation is applicable to activities associated with all of the alternatives.

\subsection{POLYCHLORINATED BIPHENYLS}

The Toxic Substances Control Act of 1976 (TSCA) and WAC 173-303 regulates the management and disposal of PCB and PCB wastes. Implementation regulations in 40 CFR 761 contain requirements for management of waste, spills, and cleanup of PCB-contaminated paint and debris. The ERDF is authorized to accept certain PCB waste for disposal. Implementation in 40 CFR 761.62(b)(1)(I) allows for applied paint to be disposed of in solid waste landfills permitted, licensed, and registered by the EPA or designated agency. Any PCB waste that does not meet the ERDF waste acceptance criteria would require prior approval by EPA to be sent to 
BHI-01299

Rev. 0

another approved PCB storage area, including the CW:MC, that meets the substintive requirements of TSCA and would be disposed at a TSCA-approved disposal facility. These regulations apply to the removal alternative and the interim stabilization (if the sump contents are removed).

\subsection{ENVIRONMENT, SAFETY, AND HEALTH STANDARDS}

Worker protection standards are described in Occupational Safety and Health Administration (OSHA) regulations, national consensus standards, and DOE Orders (e.g., 29 CFR 1910, 29 CFR 1926, NFPA 1990, WAC 29662, and DOE Order 5400.5 Radiation Protection of the Public and Environment). Exposure limits, personnel protection requirements, and decontamination methods for hazardous chemicals are established in 29 CFR 1910. The 29 CFR 1910 also requires identification and mitigation of physical hazards posed by a facility to workers including (but not limited to) confined spaces, falling hazards, fire, and electrical shock. The 29 CFR 1926 provisions establish requirements for worker safety during construction activities. Known and suspected chemical inventories in each site will be screened during the design phase against the criterial of DOE-STD-1027-92 (DOE 1992) to determine the appropriate requirements for environmental, safety, and health requirements. These regulations apply to all of the alternatives.

\subsection{EVALUATION OF ALTERNATIVES}

This section evaluates whether the alternative achieves adequate overall elimination, reduction, or control of risks to human health, worker protection, and the environment that are posed by the likely exposure pathway. Reducing the potential threat to acceptable levels is a threshold requirement and is the primary objective of the S\&M program.

The continued S\&M action alternative provides no additional protection of human health, worker protection, and the environment except radioactive decay of contaminants over time and confinement of contaminants by the operating exhaust system and hood confinement structure. The interim stabilization and complete removal action altematives protect human health and the environment by taking action to stabilize or remove hazards posed by contaminants within the Plutonium Loadout Hood.

\subsection{LONG-TERM EFFECTIVENESS}

This section assesses whether the alternative leaves an unacceptable risk before final remedial action of the REDOX Facility. The continued S\&M alternative would likely increase risk in the long-term because of hood deterioration, aging stack, compliance upgrades required for the stack, and general facility aging. This may result in a migration of contamination outside of the hood, into the REDOX Facility North Sample Gallery, or potentially release to the environment.

The remaining alternatives would be more effective at addressing threats posed by contaminants in the Plutonium Loadout Hood. With the stabilization alternative, the contamination is left in 
place but "fixed" to prevent spread of contaminants past the hood boundary area. The removal alternative would remove contamination and eliminate the potential risk of the contamination currently in the Plutonium Loadout Hood.

\subsection{REDUCTION OF TOXICITY, MOBILITY, OR VOLUME}

These criteria assess the potential reduction of contaminant toxicity, mobility, or volume through treatment and assess whether the alternative permanently or significantly reduces the hazard posed by presence of the contaminant. The continued S\&M alternative provides no near-term reduction in toxicity, mobility, or volume through treatment. Mobility of hazardous substances will eventually increase because of aging of the current facility. The interim stabilization alternative(s) would not provide a reduction of contaminant toxicity, but would minimize mobility of waste materials outside of the hood confinement structure. The disposal alternative will also eliminate the toxicity and mobility of contaminants by removal of the entire hood assembly and process vessels from the facility but would generate an increase of waste volume by removal of the entire hood.

Treatment, other than fixatives in place or during removal of the hood is not considered; however, other treatment may be required to meet waste disposal criterial for the material removed and disposed.

\subsection{IMPLEMENTABILITY}

The implementability criteria assesses whether the alternatives are technically and administratively feasible: all alternatives are feasible. Components of all the alternatives represent established technologies and methods that are routinely implemented at the Hanford Site.

\section{$7.4 \operatorname{CosT}$}

The cost criterion evaluates whether the alternatives are cost effective.

Any wastes generated during the stabilization or removal alternatives are estimated to include the following disposal costs:

1. TRU designated waste $\$ 215$ per cubic foot with disposal at the CWMC

2. $\quad$ Mixed non-TRU waste not going to ERDF at $\$ 78$ per cubic foot

3. Mixed non-TRU waste with disposal at $\$ 27$ per cubic foot at the ERDF. 
BHI-01299

Rev. 0

Table 5. Disposal Costs.

\begin{tabular}{|c|c|c|c|c|}
\hline Alternative & Waste Cost & $\begin{array}{c}\text { Engineering/Safety Approval/Air } \\
\text { Permit/Criticality } \\
\text { Evaluation/Work Package } \\
\text { Preparation }\end{array}$ & Implementation & $\begin{array}{l}\text { Total } \\
\text { Cost }\end{array}$ \\
\hline $\begin{array}{l}\text { SEM for } 10 \\
\text { years }\end{array}$ & .50 & $\$ 5,000$ total or $\$ 500$ per yeitr & $\begin{array}{l}\$ 1+0,000 \text { for routines, } \\
\text { smears, and stack } \\
\text { inspections over } 10 \text { years } \\
\text { with no contingency for } \\
\text { emergencies or stack } \\
\text { tailures }\end{array}$ & $\begin{array}{c}\$ 1+.500 \text { per } \\
\text { year or } \\
\$ 1+5.000 \text { over } \\
10 \text { years }\end{array}$ \\
\hline $\begin{array}{l}\text { Interim } \\
\text { stabilization }\end{array}$ & $\begin{array}{c}\$ 2.200 \\
1 \text { biurrel TRU }\end{array}$ & $\$ 12 \$ .000$ & $\begin{array}{l}\$ 3+5,800 \text { for stabilization } \\
\text { and deactiviting stack }\end{array}$ & $\$ 476.000$ \\
\hline $\begin{array}{l}\text { Complete } \\
\text { removal }\end{array}$ & $\begin{array}{l}\$ 72,600 \text { for } \\
33 \text { barrels of } \\
\text { TRU and } \\
13 \text { barrels of } \\
\text { ERDF-bound } \\
\text { waste }\end{array}$ & $\begin{array}{l}\$ 756,600 \text { (based on experience from } \\
233-S \text { ) }\end{array}$ & $\begin{array}{l}\$ 2,0 \$ 3,400 \text { (balsed on } \\
\text { experience from 233-S) }\end{array}$ & $\$ 2.912 .600$ \\
\hline
\end{tabular}

\subsection{RECOMMENDED ACTION ALTERNATIVE}

The current S\&M alternative is the lowest cost per year but carries the highest risk of contamination spread of the three alternatives. This option also depends upon no further contamination "drips" of the L-16 to H-4 line behind the Plutonium Loadout Hood. Also, the stack for the Plutonium Loadout Hood is aging and does not meet current American Nuclear Society Institute (ANSI 13.1) code which EPA has adopted as guidance for stacks. It is possible that within 2 or 3 years, a major upgrade cost would be incurred to modify the 296-S-2 stack.

The interim stabilization alternative carries an initial cost that is approximately three times order of magnitude higher than the current S\&M alternative; however, much of this cost would have to be incurred at some point so decontamination and remediation of the Plutonium Loadout Hood could be conducted. Therefore, any action to interim stabilize the hood at the present time would only aid the final remediation effort. The cost (if incurred currently) would not only protect future remediation personnel, but also workers performing S\&M during the interim period. This option would also remove the 296-S-2 stack and eliminate the need for future costly upgrades of the exhaust system.

In the future, when the Canyon Disposition Initiative (CDI) is evaluated for the REDOX Facility, the interim stabilization altermative recommended by this report would not adversely impact any decision for the CDI efforts planned for this plant. Because the North Sample Gallery is outside the boundary wall of the canyon structure, it is anticipated that this section of the building will be fully decontaminated and removed during the CDI process. Therefore, the interim stabilization would again aid in the final effort.

The removal alternative carries a higher cost than either of the first two altematives. This 
BHI-0 1299

Rev. 0

alternative completely removes the risk of contaminants spread and also removes the 296-S-2 stack. The level of worker discipline and manigement support required to conduct this work would require an extensive Operation Readiness Review by the ERC and RL. In addition. to meet verbal objectives stated by EPA in Section 1.0, an EE/CA would need to be prepared and submitted for the removal action to take place.

Based on overall protection and short-and long-term effectiveness until the REDOX Facility final cleanup decision has been made, the recommended altermative for the Plutonium Loadout Hood is the interim stabilization alternative. This alternative provides for continued maintenance of the facility as well as the identification and response to potential release of hazardous substances that could adversely impact human health and the environment. The stabilization alternative is protective of workers, the public, and the environment and allows for a coordinated cleanup of the REDOX Facility in the future when detailed remedial action is planned.

\subsection{REFERENCES}

10 CFR 835, "Occupational Radiation protection, " Code of Federal Regulations, as amended.

29 CFR 1910, "Occupational Safety and Health Standards," Code of Federal Regulations, as amended.

29 CFR 1926, "Occupational Safety and Health Standards for the Construction Industry," Code" of Federal Regulations, as amended.

40 CFR 61, "National Emissions Standards in Hazardous Air Pollutants," Code of Federal Regulations, as amended.

40 CFR260, "Hazardous Waste Management System: General," Code of Federal Regulations, as amended.

40 CFR 261, "Identification and Listing of Hazardous Waste," Code of Federal Regulations, as amended.

40 CFR 262, "Standards Applicable to Generators of Hazardous Waste," Code of Federal Regulations, as amended.

40 CFR 266, "Standards for the Management of Specific Hazardous Wastes and Specific Types of Hazardous Waste Management Facilities," Code of Federal Regulations, as amended.

40 CFR 268, "Land Disposal Requirements," Code of Federal Regulations, as amended.

40 CFR 761, "Polychlorinated Biphenyls (PCB's) Manufacturing, Processing Distribution in Commerce, and Use Prohibition," Code of Federal Regulations, as amended.

BHI-EE-01, Environmental Investigations Instructions, Bechtel Hanford, Inc., Richland, Washington. 
BHI-01299

Rev. 0

BHE-FS-01. Field Support Administration. Section 1.1. "Access Control and Administration for ERC Facilities."

BHI, 1997, In-Situ Non-Destructive Radiological Characteri-ation of Selected 202-S Reduction Oxidation (REDOX) Facility Sample Gallery Pipes and Véssets, BHI-00994, Vol. 1.

Rev. 0, Bechtel Hanford, Inc., Richland, Washington.

BHI, 1998a, Letter of Instruction for the Sample Analysis of the Reduction Oxidation Facility (202-S) Plutonium Loadout Hood (CCN 054016, July 24). Bechtel Hanford Inc., Richland Washington.

BHI, 199Sb. Reudiness Assessment Report for the REDOX Plutonium Loadout Hood, RA-9800004, Bechtel Hanford, Inc., Richland, Washington.

BHI, 199Sc, Environmental Restoration Disposal facility Waste Acceptance Criteria, BHI-00139, Rev. 3, Bechtel Hanford, Inc., Richland Washington.

BHI, 1999, Interim Characterization Report for the REDOX Plutonium Loadout Hood, BHI-01255, Rev. 0, Bechtel Hanford, Inc., Richland Washington.

BHI, 1999. (draft) Safery Evaluation of the Plutonium Loadout Hood, Bechtel Hanford Inc., Richland Washington.

Cleam Air Act of 1955,42 U.S.C. 7401 , et seq.. as amended.

Comprehensive Environmental Response, Compensation, and Liability Act of 1980 , 42 U.S.C. 9601 , et seq., as amended.

DOE, 1992. Hazard Categorization and Accident Analysis Techniques for Compliance with DOE Order 5480.23, Nuclear Safety Analysis Reports. DOE-STD-1027-92. U.S. Department of Energy, Washington D.C.

DOE-RL, 199S, Sampling and Analysis Plan for the REDOX Plutonium Loadout Hood, DOE/RL-97-75, Rev. 0, U.S. Department of Energy, Richland Operations Office, Richland, Washington.

Ecology, EPA, and DOE, 1998, Hanford Federal Facility Agreement and Consent Order, 2 Vols., as amended, Washington State Department of Ecology, U.S. Environmental Protection Agency, and U.S. Department of Energy, Olympia, Washington.

Kerr, N. R., 1998, REDOX Facility Safety Analysis Report, BHI-01142, Rev. 0, Bechtel Hanford, Inc., Richland, Washington.

NFPA, 1990, National Electric Code, NFPA 70, National Fire Protection Association, Quincy, Massachusetts.

Resource Conservation and Recovery Act of 1976, 42 U.S.C. 6901, et seq., as amended.

Toxic Substances Control Act of 1976, 15 U.S.C. 2601 , et seq., as amended. 
BHI-0 1299

Rev. 0

WAC 173-303, "Dingerous Waste Regulations," Whahingron Administrative Code, als amended.

WAC 173-304, "Minimum Functional Standards for Solid Waste Handling." Washington Administrative Code, as amended.

WAC 173-400, "General Regulations for Air Pollution Sources," Hashington Administrative Code. as amended.

WAC 173-303-630, "Use and Management of Containers," Washington Administrative Code. as amended.

WAC 246-247, "Radiation Protection - Air Emissions," Washington Administrative" Code, as amended. 
BHI-01299

Rev. 0

APPENDIXA

SEISMIC CALCULATIONS 
BHI-01299

Rev: 0

A-ij 
Originator R. S. Rajagopal Date 8-20-99 Calc. No. 0200W-CA-C0156 Rev. No. 0 Project RERP Job No. 22192 Checked

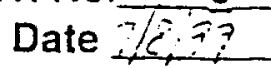
Subject Evaluation of REDOX-North Gallery Structure for Pu Loadout Hood Protection Sheet No. 1

\section{TABLE OF CONTENTS}

Sheet No.

4. STRUCTURAL CAPACITIES

5. SEISMIC EVALUATION

6. LOAD DROP EVALUATION

7. COMBINED SEISMIC AND LOAD DROP EFFECTS ON NORTH GALLERY ROOF SLAB

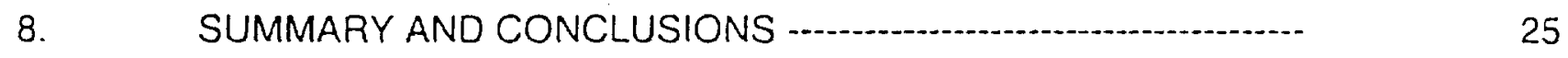

9. REFERENCES

10. LIST OF DRAWINGS

\section{ATTACHMENTS:}

A. REDOX (Original "GT Strudl" Model) Input for Seismic Analysis (Using Original Ground Response Spectrum for 10\% Damping)

B. REDOX (Original "GT Strudl" Model) Output for Seismic Analysis

C. REDOX (Corrected Coordinates in "GT Strudl" Model) Input for Seismic Analysis (Using Original Ground Response Spectrum for 10\% Damping)

D. REDOX (Corrected Coordinates in "GT Strudl" Model) Output for Seismic Analysis (Using Original Ground Response Spectrum for 10\% Damping)

E. REDOX (Corrected Coordinates in "GT Strudl" Model) Input for Seismic Analysis (Using Ground Response Spectrum for "Existing PC3 Stru." -10\% Damping) --.--

F. REDOX (Corrected Coordinates in "GT Strudl" Model) Output for Seismic Analysis (Using Ground Response Spectrum for "Existing PC3 Stru." -10\% Damping) -..--

G. REDOX "GT Strudl" Model: Excerpted from Ref. 7 
BHI-01299

Rev. 0 
BHI-01299

Rev. 0

\section{CALCULATION COVER SHEET}

Project Title Richland Environmental Restoration Project (RERP) Job No. 22192 Area $0200 \mathrm{~W}$

Discipline _Civil/Structural

*Calc. No. 0200W-CA-C0156

Subject Evaluation of REDOX - North Gallery Structure for Protection of Pu Loadout Hood Computer Program None Program No. N/A

Committed Calculation $\quad \bigotimes \quad$ Preliminary $\quad \square \quad$ Superseded $\square$

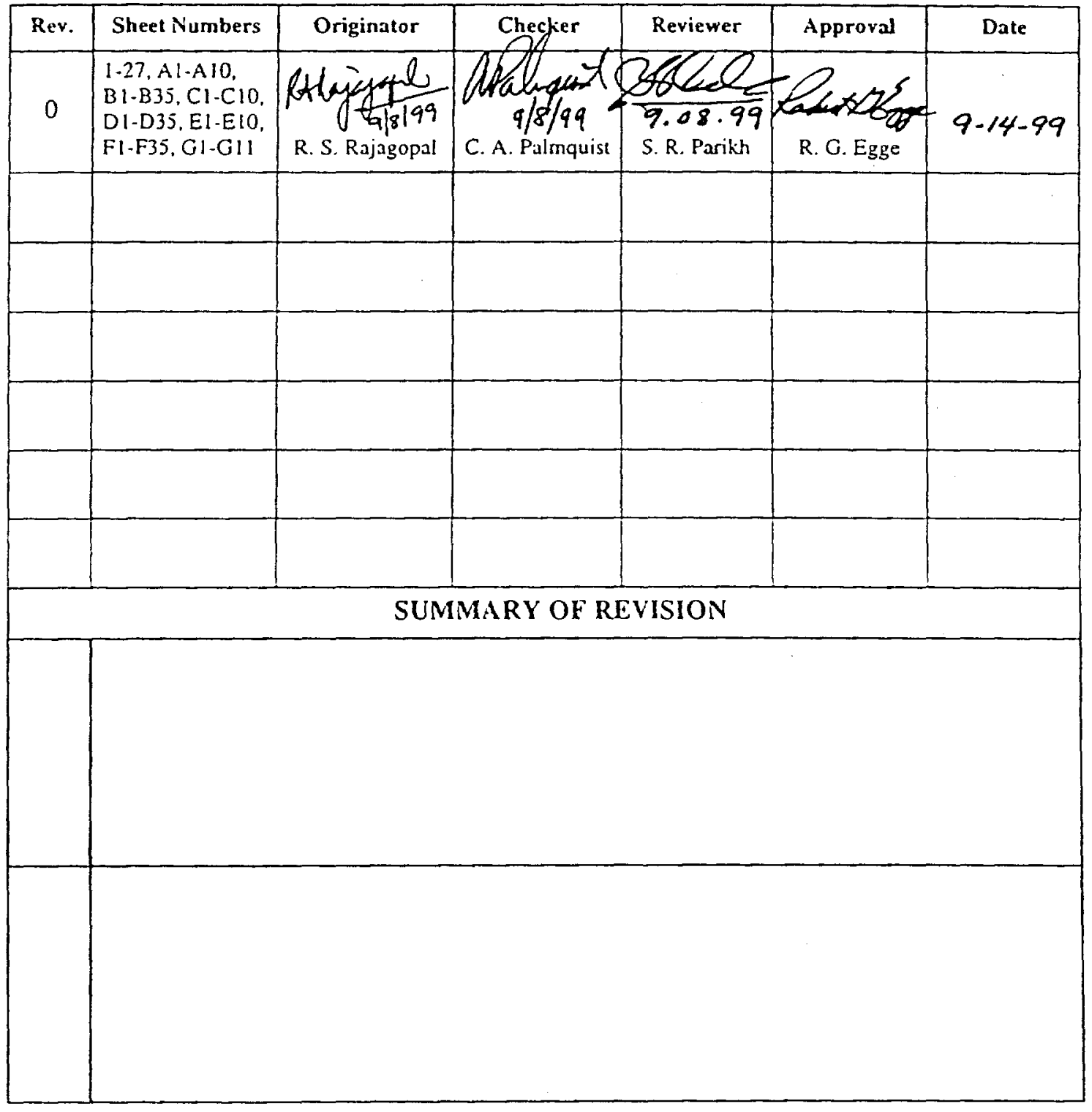

- Obtain Calc. No. from DIS

$11 / 98$

DED1 437.03 
BHI-01299

Rev. 0 Date 3iz/2? Subject Evaluation of REDOX-North Gallery Structure for Pu Loadout Hood Protection Sheet No.

The purpose of this calculation is to evaluate the ability of the walls and slabs of the North Gallery portion of the REDOX building to withstand seismic forces. In addition, the purpose is also to evaluate the roof slab of the North Gallery for the potential load drop effects from the postulated failure of North Canyon walls above El. 133'-4" (Crane rail elevation). These evaluations are performed for verification of the seismic safety of the Plutonium Loadout Hood located on the floor at El. 88'-0" towards the west end of the North Sample Gallery.

\section{$2.0 \quad$ BACKGROUND:}

The Pu Loadout Hood is located on the floor at El. 88'-0" in the North Sample Gallery of the REDOX building. A seismic evaluation of the North Gallery of REDOX is performed for verification of the seismic safety of the Pu Loadout Hood.

Previously, in January 1997, Pete Carrato had performed a seismic capability evaluation of the REDOX building (see report attached to DIS chron. \# 043500, Reference 7). The seismic load considered in the evaluation was based on the previous Hanford Plant Standards, SDC 4.1. Figure 5 seismic ground spectrum for $10 \%$ damping, having peak spectral value of $0.2 \mathrm{~g}$. \& ZPA value of $0.12 \mathrm{~g}$. The evaluation indicated that the walls above the crane girder elevation (EI. 133'-4") and the roof structure will not withstand the seismic forces resulting from the above spectrum. However, subsequent calculations [Calculation Nos. 0200W-CA-C0027 (Ref 8) and 0200W-CAC0033 (Ref 9)] indicated that the potential load drop due to collapse of the roof, roof truss, and the walls above EI. 133'-4", will not impair the structural integrity of the REDOX Canyon cell cover blocks at El. 105'-6". Thus, the radiologic inventories inside the canyon cells are protected against seismic forces.

Presently, additional evaluation efforts are undertaken to determine the structural adequacy of the REDOX North Gallery walls and slabs against seismic forces and potential load drop effects. This evaluation is performed to verify protection of the Pu Loadout Hood against seismic forces. Evaluation is also performed for the potential load drop effects of the postulated failure of North Canyon wall on the North Gallery roof slab. The load drop scenario is pictorially shown on sheet 3. 
BHI-01299

Rev. 0
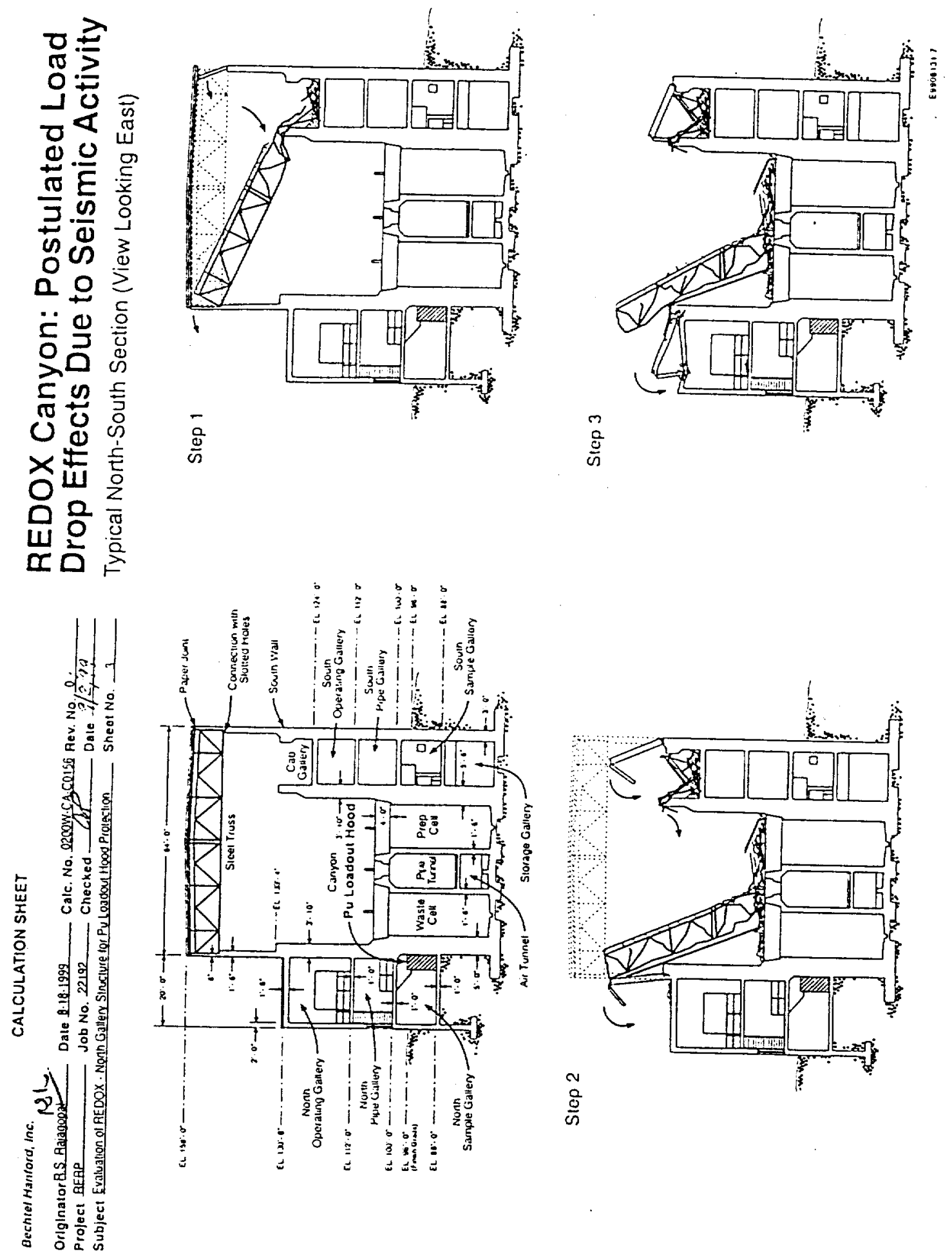
BHI-01299

Rev. 0

Originator R. S. Rajagopal Date 8-20-99 Calc. No. 0200W- CA-C0156 Rev. No.

Project RERP

Job No. 22192

Checked

Date

Sheet No.

Subject Evaluation of REDOX-North Gallery Structure for Pu Loadout Hood Protection

\subsection{APPROACH:}

(1) Determine structural capacities (Moment and Shear capacities) of the walls and slabs of the North gallery walls and slabs from the structural details shown on the drawings listed in Section 10.0 and using ACl-318 code (Ref. 3) and Reference 2.

(2) Determine input seismic response spectra for "Existing PC3 Structures" in 200 West area from References 11,12 and 13.

(3) Perform seismic analysis for the determination of seismic forces (Moments and Shears) using the "GT STRUDL" model of Pete Carrato (Ref. 7) with the seismic spectra defined in 2 above.

(4) Perform Load drop evaluation using the methodology provided in Reference 10.

(5) Compare the structural capacity against the demand of the seismic forces and load drop effects to verify the structural adequacy of the walls and slabs of the North gallery in the REDOX building. 
BHI-01 299

Rev. 0

\section{Bi. $2393 .+-c \lambda$}

Originator R.S.Rajagofal Date 7-15-99 Calc. No. 00156 Project RERP Job No. $2219:$

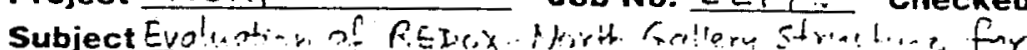

Pu Loadriat Hood iratection.

Checked

4.0 STRUGTIRAL CAPAEITIES

REDOX-NORTH GALLERY WALLS \& SLABS

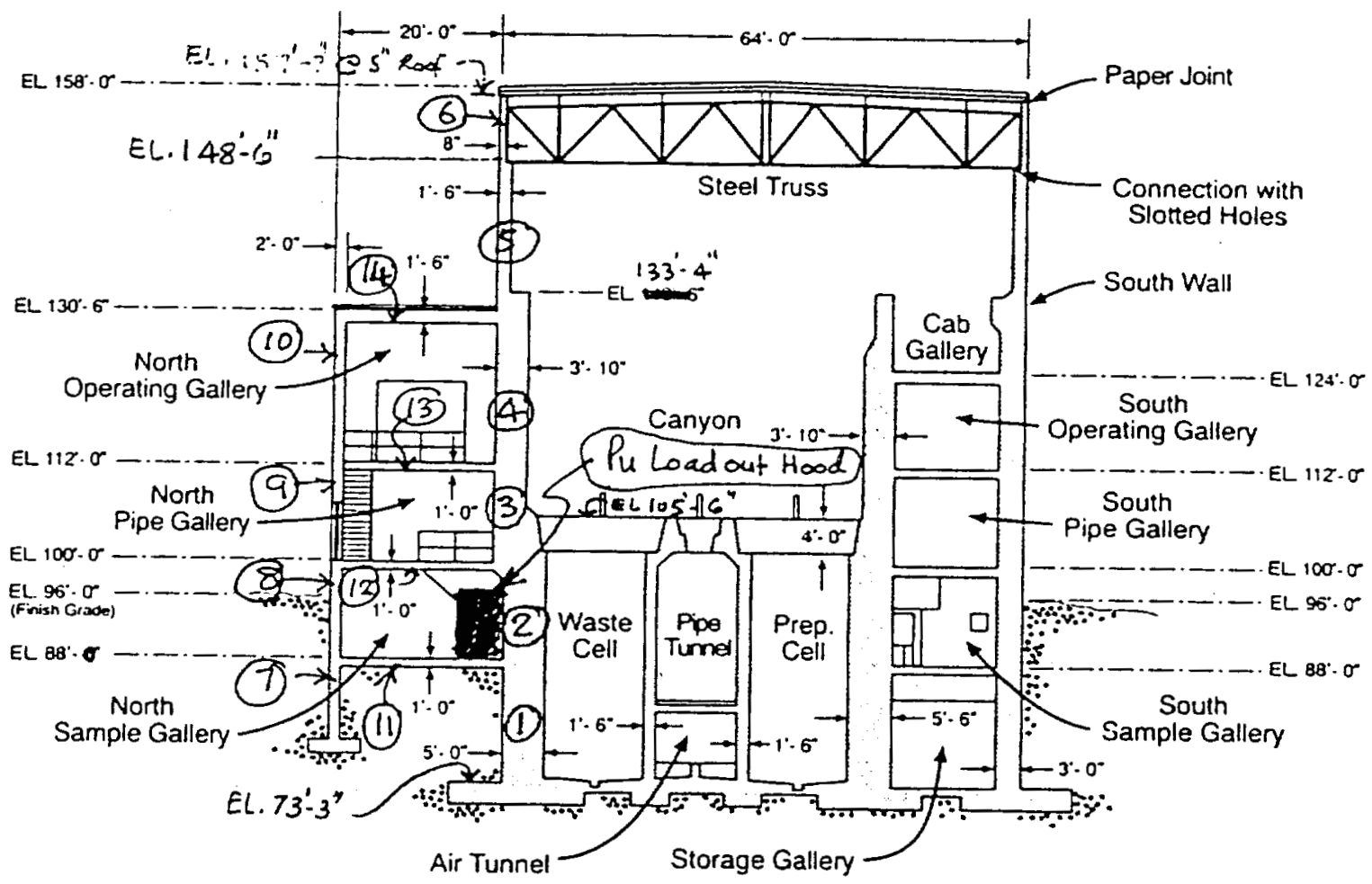

Typical North-South Section (View Looking East)

Structural Moment and shear capalatier of the

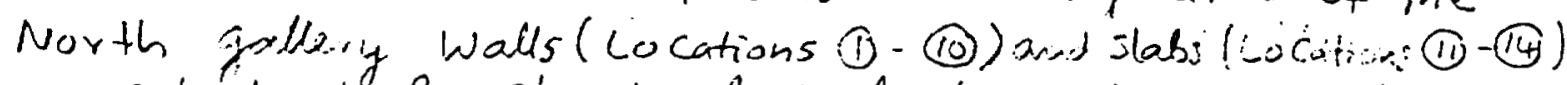
in crlculotel for structurat. evaluation. The rebar fizpe and spalergs for these locaticuse are tablesete $i$ on the

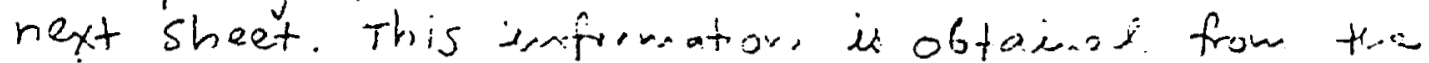
refuaned Hawitid site drowings. 
BHI-01299

Rev. 0

$0.30, \pi-4$

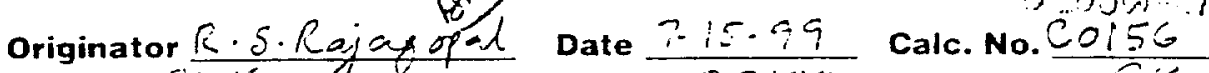
Project F.T Job No.2219 Checked Ch

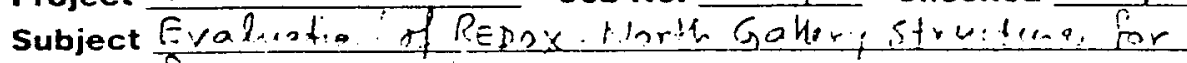
f.e besedered Hond frotn.t...

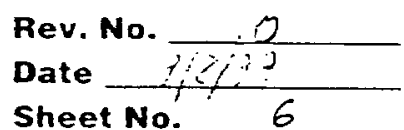

4.0 Structural Capacities of REDOX-North Gulery Wall \& Slahe (Contd) WALL / SLAB INFORMATION FROM DRAWIIII

\begin{tabular}{|c|c|c|c|c|}
\hline $\begin{array}{l}\text { WALL/ } \\
\text { SLAS } \\
\text { NO. }\end{array}$ & LOCATION & $\begin{array}{l}\text { WALL/ } \\
\text { SLAB } \\
\text { THICKNES }\end{array}$ & RE.BARS & $\begin{array}{l}\text { REFECENCE } \\
\text { DRAUNASG }\end{array}$ \\
\hline (1) & $\begin{array}{l}\text { Ganyon wall Ber, } \\
\text { Found. El. } 88^{\prime}-0^{\prime \prime}\end{array}$ & $60^{\prime \prime}$ & $\begin{array}{l}\text { "ss.e Q"c. } \\
\text { Q Each Face }\end{array}$ & $\begin{array}{l}\text { Sect. } 180-180 \\
\text { Durg. H-2-8376 }\end{array}$ \\
\hline (3) & $\begin{array}{l}\text { Canjon wall Bet. } \\
\text { El. } 88^{\circ}-0^{\prime \prime} \text { \& } 100^{\circ}-0^{\circ}\end{array}$ & $60^{\prime \prime}$ & $\begin{array}{l}\text { "sq.@ @ } \\
\text { Q Each Fare }\end{array}$ & $\begin{array}{l}\text { Seet. } 180-180 \\
\text { Dwrg. } 1-2-8376\end{array}$ \\
\hline (3) & \begin{tabular}{|l|} 
Canyou wall Bet. \\
El. $10^{\circ}-0^{\circ} \dot{\varepsilon} 112^{\prime}-0^{\circ}$
\end{tabular} & $46^{\prime \prime}$ & $\begin{array}{l}\text { "si:@ } 9 q^{\prime \prime C} . \\
\text { Each Faiz }\end{array}$ & $\begin{array}{l}\text { Sect. } 180-180 \\
\text { Dugg. } 1-2-8376\end{array}$ \\
\hline (4) & $\begin{array}{l}\text { Canjon wall Bet. } \\
\text { El.112'-0" } 5133^{\prime}-4^{\prime \prime}\end{array}$ & $46^{\prime \prime}$ & $\begin{array}{l}1^{\prime \prime} s_{1} @ q^{n} c . \\
\text { @ Each Fane }\end{array}$ & $\begin{array}{l}\text { Sect. } 180-180 \\
\text { Dung. A- }=-8376\end{array}$ \\
\hline (5) & $\begin{array}{l}\text { Canjon wall Bet. } \\
\text { E1. } 133^{3}-4^{\prime \prime} \& 148^{\circ}-6^{\circ}\end{array}$ & $18^{\prime \prime}$ & $\begin{array}{l}3 / 4^{\prime \prime} \$ @ q^{\prime \prime} \mathrm{C} . \\
\text { @ Each Fara }\end{array}$ & $\begin{array}{l}\text { Sect. } 180-180 \\
\text { Dwg.H-2-8370 }\end{array}$ \\
\hline (6) & 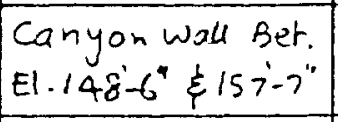 & $8^{\prime \prime}$ & $\begin{array}{l}1 / 2^{\prime \prime} \phi \odot q^{\prime \prime} c . \\
\text { 巳Each Fau. }\end{array}$ & $\begin{array}{l}\text { Sect. } 180-180 \\
\text { Drig. } H-2-8376 \\
\end{array}$ \\
\hline 7) & $\begin{array}{l}\text { North Wall Bet. } \\
\text { Found , है El. } 88^{\circ}-{ }^{\prime \prime}\end{array}$ & $24^{\prime \prime}$ & $\begin{array}{l}1 / 8 \% \text { e } 90 . \\
\text { a Each rase }\end{array}$ & $\begin{array}{l}\text { Sect } 1 6 8 - 1 6 8 \longdiv { 1 6 9 - 1 6 9 } \\
\text { Dug. } 4-2-8289\end{array}$ \\
\hline (8) & $\begin{array}{l}\text { North wall Bet. } \\
\text { El.88'- } 0^{\circ} \text { \& } 100^{\prime}-0^{\prime \prime}\end{array}$ & $24^{\prime \prime}$ & $\begin{array}{l}\text { isy. @ q"c. } \\
\text { @Eadh Fare }\end{array}$ & $\begin{array}{l}\text { Sect. } 168-168 / 159-169 \\
\text { Dung. } 4-2-8289\end{array}$ \\
\hline (9) & $\begin{array}{l}\text { North wak Bet. } \\
\text { E1. } 100^{-}-0^{4} \& 112^{\prime}-0^{4}\end{array}$ & $24^{4}$ & $\begin{array}{l}\text { "sq.e } q^{\prime \prime} \mathrm{c} \text {. } \\
\text { Q Each Face }\end{array}$ & $\begin{array}{l}\text { Sect. } 168-168 / 169-169 \\
\text { Ding. } 4-2-8 \geq 89\end{array}$ \\
\hline (10) & \begin{tabular}{|l|} 
North wall Bet. \\
El.112-0" $5130^{\circ}-6^{\circ}$
\end{tabular} & $24^{\prime \prime}$ & $\begin{array}{l}\text { "sa@g"C. } \\
\text { @each Fase }\end{array}$ & $\begin{array}{l}\text { Sect. } 158-168 / 159-169 \\
\text { Dugg. 11-2-8289 }\end{array}$ \\
\hline (11) & Slaf@ @ El. $88^{\prime}-0^{\circ}$ & $12^{\prime \prime}$ & $\begin{array}{l}\text { "sa,@q" } \mathrm{c} \text {. } \\
\text { Top s. Bot. }\end{array}$ & $\begin{array}{l}\text { Dwg. H-2-7726 \& } \\
\text { Dwg. H-2-8391 }\end{array}$ \\
\hline 12 & $S l a b$ \& El. $100^{\prime} \cdot 0^{\prime \prime}$ & $12^{11}$ & $\begin{array}{l}\text { "sq, @ Q"C. } \\
\text { Top } \leqslant \text { Bot }\end{array}$ & Dusg.H-2-7728 \\
\hline (13) & Slats@El. $112^{\prime}-0^{\prime \prime}$ & $12^{4}$ & 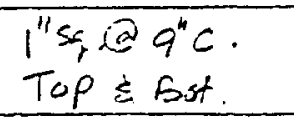 & insg. H-2-7756 \\
\hline (14) & 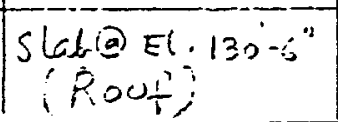 & $18^{\prime \prime}$ & $\begin{array}{l}\text { 1"se@g"c. } \\
\text { Top \& Bot. }\end{array}$ & Dug. H-2-7757 \\
\hline
\end{tabular}


BHI-01299

Rev. 0

Bechtel Hanford, Inc.

CALCulation SHEET

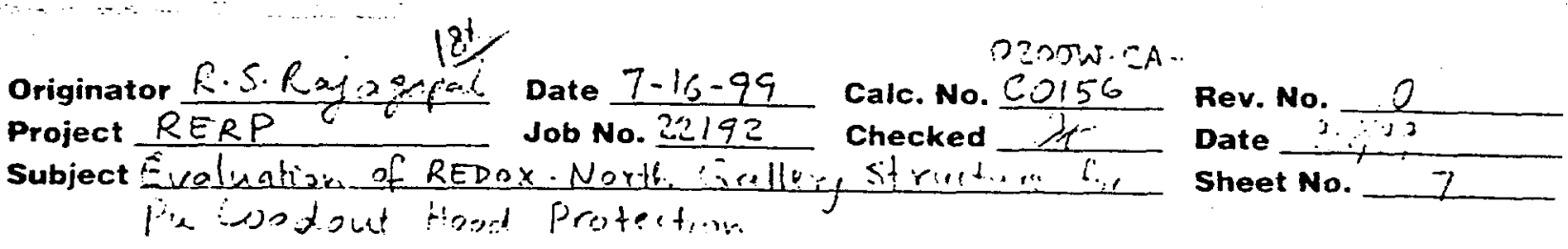

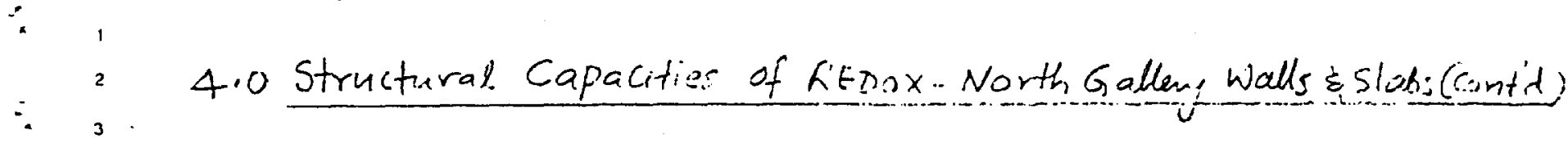

Moment and shear capacities one computed using (a) Material Properties. Without Dynamic Increase Faitor (b) Material properties with Dynamic Increase Fatter.

Material Properties used on Sheets $5 \geqslant 6$ of Ref. 8 are repeated as follows:

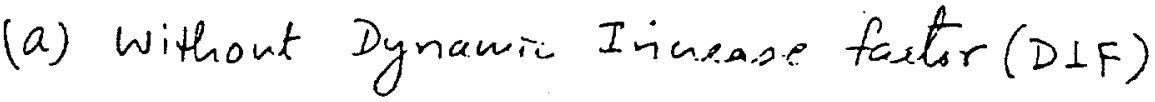

$$
\begin{aligned}
& f_{c}^{\prime}=4500 p_{i} \text { (Concrete) } \\
& f_{y}=40000 \text { ps; (Rear) } \\
& E_{c}=57000(4500)^{1 / z}=3,824,000 \text { pis }=3824 \text { si (conc) } \\
& E_{S}=29000 \mathrm{ksi} \text { (Steal rear) } \\
& n=E_{S} / E_{C}=29000 / 3854=7.6
\end{aligned}
$$

(b) With Dynamic Increase factor (DIF)

$D I F=1.25$ for Concrete, $D I F=1.20$ for Steel Rebar

$$
\begin{aligned}
& f_{c}^{\prime}-d y_{n}=(1.25)(4500)=5625 \text { Psi (concrete) } \\
& f_{f}-d_{\text {syn }}=(1.20)(4000:)=48000 p_{s} ; \text { (Radar) } \\
& E_{c}=57000(5625)^{1 / 2}=4,275,000 \text { Psi }=4275 \mathrm{ks} \text { (toni) } \\
& E_{S}=29000 \mathrm{ksi} \text { (steel reba) } \\
& n=E_{s} / E_{C}=29000 / 4275=\underline{6.8}
\end{aligned}
$$

33

34

35

36

$E 9612009$

A-9 
BHI-01299

Rev. 0

Bechtel Hanford, Inc.

Calculation sheet

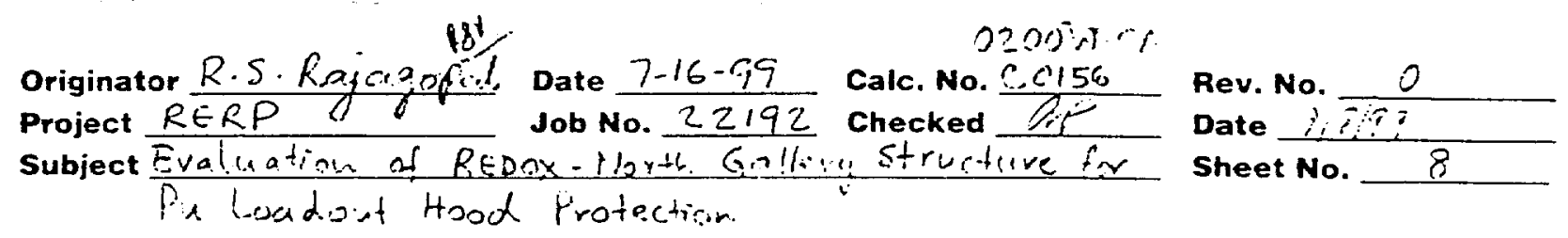

4.0 Structural. Capacities of REDox. North galler, walls \& Slab: (Cont'd)
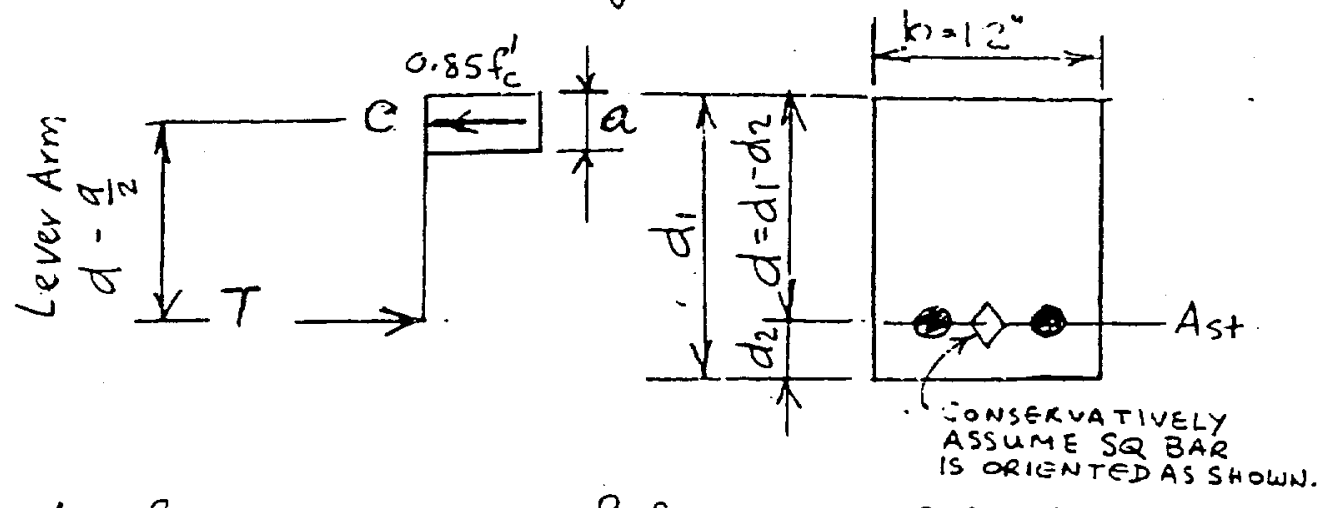

$$
\begin{aligned}
& T=\text { Ast fy } \\
& c=0.85 f_{c}^{\prime} b a \\
& T=c \Rightarrow a=\frac{\text { Ref.2 and Ref.3 (AcI ile.95) }}{0.85 f_{c}^{\prime} b}
\end{aligned}
$$

- Ultimate Moment capacity $=M_{\text {cap }}^{u}=A_{\text {st }} f_{y}\left(d-\frac{a}{2}\right)$

- Utimate Shear Capality $=V_{\text {cap }}^{u}=b \cdot d \cdot v_{c}$

$$
\begin{aligned}
v_{c}=2 \sqrt{i_{c}^{i}} & =2 \sqrt{4500}=134 \text { PSi } \quad \text { No/0 DIF } \\
& =2 \sqrt{5625}=150 \mathrm{Psi} \text { w/DIF }
\end{aligned}
$$

$d_{2}=$ Cover $+\frac{\text { bar Iia. }}{2}$ Per Spec.HW-4301(Ref.5)Ssct.6.2.3 Covese for walls is ile $\mathrm{l}_{\mathrm{s}}=3 / 4^{n} \mathrm{~min}$.

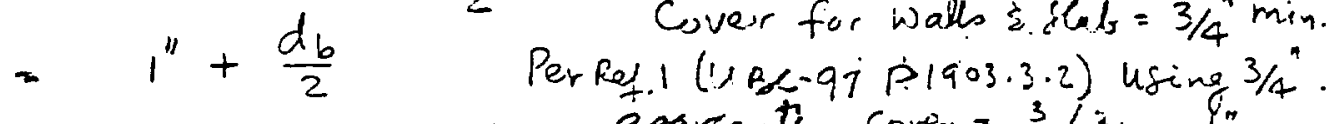

aggreg-te, cover $=\frac{3}{4} / 3 / 2=1$

- Except. for Sef.180-180

Reinf.: $1 / 2$ " \& Bor, $\quad d_{2}=\frac{0.5^{\prime \prime}}{2}+1 "=1.25^{\prime \prime}$

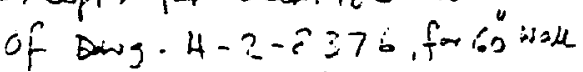

$$
3 / 4 \text { ded } \quad d_{2}=\frac{0.75}{2}+1 " \cdot 11.38^{\prime \prime}
$$

Which rinowe $6 "$ "learorean,

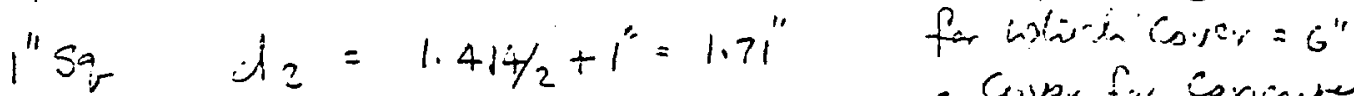

$11 / 8 S^{\prime \prime}$.,$\quad d_{2}=\frac{(1.414)(1.125)}{2}+1=1.80^{\circ}$

- Cosper for Coricuter

Lefortive sagaindigrour $\hat{z}=3^{\prime \prime}$

$E 961200$

A-10 
Originator R.S.R.gagean

Date $7.19-99$ Project RERF Job No. 22192

Calc. No. $0.01 \%$

OZ.OOW-CA.

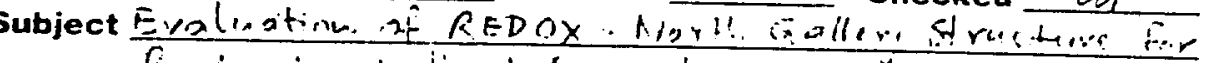

Rev. No.

Date ? $\overline{s i ? 9}$

Sheet No. G Fi. Langont it and froteition

\begin{tabular}{|c|c|c|c|c|c|c|c|}
\hline$\left|\begin{array}{l}\text { WAll } \\
\text { OR } \\
\text { SLAB }\end{array}\right|$ & $\begin{array}{l}\text { Ast } \\
\left(\mathrm{in}^{2}\right)\end{array}$ & $\begin{array}{l}d_{1} \\
(\text { in })\end{array}$ & $\begin{array}{l}d z \\
\text { (in) }\end{array}$ & $\left|\begin{array}{c}d=d_{7}-d_{2} \\
\text { (in) }\end{array}\right|$ & $a=\frac{A_{s+} f_{y}}{2.85 f_{c}^{\prime} b}$ & $\begin{array}{l}M_{\text {cap. }}^{u}=A_{s t} f_{j}\left(d-\frac{a}{2}\right) \\
\left(k^{\prime \prime} / f_{t} \text { width }\right)\end{array}$ & $\begin{array}{l}V_{c a p}^{u}=b d v c \\
(k / f+\text { width })\end{array}$ \\
\hline (1) & 1.33 & 60 & 6.71 & 53.29 & 1.16 & $\begin{array}{l}2804 \mathrm{~K}^{\prime \prime} \\
=234 \mathrm{kft}\end{array}$ & $85.7^{k}$ \\
\hline (2) & 1.35 & 60 & 6.71 & 53.29 & 1.16 & $\begin{array}{r}2804 \mathrm{k}^{\prime \prime} \\
=234 \mathrm{kfr}\end{array}$ & $85.7^{k}$ \\
\hline (3) & 1.33 & 46 & 1.71 & 44.29 & 1.16 & $\begin{array}{l}2325 \mathrm{k} \\
=194 \mathrm{kft}\end{array}$ & $71.2^{k}$ \\
\hline (4) & 1.33 & 46 & 1.71 & 44.297 & 1.16 & $\begin{array}{r}2325 \mathrm{~K}^{\prime \prime} \\
=194 \mathrm{Kfr}\end{array}$ & $71.2^{k}$ \\
\hline (5) & 0.59 & 18 & 1.38 & 16.62 & 0.51 & $\begin{array}{l}386 \mathrm{k}^{4} \\
=32 \mathrm{kfr} .\end{array}$ & $26.7^{k}$ \\
\hline (6) & 0.27 & 8 & 1.25 & 6.75 & 0.24 & $\begin{array}{l}72 k^{4} \\
-6 \mathrm{kf} \\
\end{array}$ & $10.9^{k}$ \\
\hline (7) & 1.67 & 24 & 1.80 & 22.20 & 1.47 & $\begin{array}{l}1451 \mathrm{k}^{\prime \prime} \\
=121 \mathrm{kfr}\end{array}$ & $35.7^{k}$ \\
\hline (8) & 1.33 & 24 & 1.71 & 22.29 & 1.16 & $\begin{array}{r}1155 k^{\prime \prime}= \\
96 k f r\end{array}$ & $35.8^{k}$ \\
\hline (9) & 1.33 & 24 & 1.71 & 22.29 & 1.16 & $\begin{array}{r}1155 k^{\prime \prime}= \\
96 \mathrm{kfr}\end{array}$ & $35.8^{k}$ \\
\hline (10) & 1.33 & 24 & 1.71 & 22.29 & 1.16 & $\begin{array}{r}1155 \mathrm{k}^{n}= \\
96 \mathrm{kfr}\end{array}$ & $35.8^{k}$ \\
\hline (11) & $1.33^{\circ}$ & 12 & $3.7 i$ & .8 .29 & 1.16 & $\begin{array}{c}410 k "= \\
34 k i r\end{array}$ & $13.3^{n}$ \\
\hline (12) & 1.33 & 12 & 1.71 & 10.29 & 1.16 & $\begin{array}{r}517 k^{\prime \prime}= \\
4: k f r\end{array}$ & $16 \cdot 6^{k}$ \\
\hline (13) & 1.33 & 12 & 1.71 & 10.29 & 1.16 & $\begin{array}{r}517 k^{\prime \prime}= \\
43 k f r\end{array}$ & $16.6^{k}$ \\
\hline (14) & 1.33 & 18 & 1.71 & 16.29 & 1.16 & $\begin{array}{r}836 \mathrm{k"}= \\
70 \mathrm{kft}\end{array}$ & $26 \cdot 2^{k}$ \\
\hline
\end{tabular}


Originator R. S. Rajagopal Project RERP

Date 8-16-99 Calc. No. 0200W- CA-C0156 Rev. No Job No. 22192

Checked Ar Date $7 / 8 \longdiv { 9 9 }$ Subject Evaluation of REDOX-North Gallery Structure for Pu Loadout Hood Protection Sheet No. 10 SEISMIC EVALUATION:

\section{SEISMIC INPUT:}

The seismic input is defined in terms of Acceleration Ground Response Spectra. For the previous analysis (Ref 7) the spectra was based on the previous Hanford Plant Standard, Figure 5 of SDC 4.1 (Ref 14) seismic ground spectrum for $10 \%$ damping, having peak spectral value of $0.2 \mathrm{~g}$ and ZPA value of $0.12 \mathrm{~g}$.

For the present analysis, the ground spectra are derived based on the site-specific seismic hazard analysis for 200 West area of the Hanford site from References 11 and 12 . The structure is considered as "Existing PC3 structure" which will have 1000 year retum period per Section 1.3 and Table 2-1 of Reference 13. The peak ground accelerations (PGA) obtained from Tables 5-1 and 5-2 of Reference 12, for 1000 years retum period for $200 \mathrm{West}$ area, are $0.188 \mathrm{~g}$ (horizontal) and 0.122 $g$ (vertical). The damping value considered is $10 \%$ based on existing SSC for Response Level 3, per Section 2.3.3 and Table 2-3 of Reference 13. The ground spectra computations for $10 \%$ damping value are shown in the following table.

\section{GROUND RESPONSE SPECTRA FOR 10\% DAMPING}

\begin{tabular}{|c|c|c|c|c|c|c|c|}
\hline \multicolumn{4}{|c|}{ HORIZONTAL SPECTRUM } & \multicolumn{4}{|c|}{ VERTICAL SPECTRUM } \\
\hline $\begin{array}{l}\text { Frequency } \\
(H Z)\end{array}$ & $\begin{array}{l}\text { Period } \\
\text { (SeC) }\end{array}$ & $\begin{array}{l}\text { Spectral Shape } \\
\text { (Ret 12. Pg B-3) }\end{array}$ & $\begin{array}{l}\text { Hor. Spect. = } \\
\text { (Hor. PGA = } \\
\text { 0188 g) (Hor. } \\
\text { Spect. Shape) }\end{array}$ & $\begin{array}{l}\text { Frequency } \\
\qquad(\mathrm{Hz})\end{array}$ & $\begin{array}{l}\text { Period } \\
\text { (Sec) }\end{array}$ & $\begin{array}{l}\text { Spectral Shape } \\
\text { (felt 12. Pg B-6) }\end{array}$ & $\begin{array}{l}\text { Ver. Spect. = } \\
\text { (Hor. PGA = } \\
\text { O188 g) (Ver. } \\
\text { Spgect. Shape) }\end{array}$ \\
\hline 33.3 & 0.030 & 1.000 & $0.188 \mathrm{~g}$ & 50.0 & 0.020 & 0.648 & $0.122 \mathrm{~g}$ \\
\hline 13.3 & 0.075 & 1.267 & $0.238 \mathrm{~g}$ & 13.3 & 0.075 & 0.968 & $0.182 \mathrm{~g}$ \\
\hline 10.0 & 0.100 & 1.422 & $0.267 \mathrm{~g}$ & 10.0 & 0.100 & 0.999 & $0.188 \mathrm{~g}$ \\
\hline 5.0 & 0.200 & 1.703 & $0.320 \mathrm{~g}$ & 5.0 & 0.200 & 0.947 & $0.178 \mathrm{~g}$ \\
\hline 3.33 & 0.300 & 1.604 & $0.302 \mathrm{~g}$ & 3.33 & 0.300 & 0.811 & $0.152 \mathrm{~g}$ \\
\hline 2.0 & 0.500 & 1.237 & $0.233 \mathrm{~g}$ & 2.0 & 0.500 & 0.481 & $0.090 \mathrm{~g}$ \\
\hline 1.0 & 1.000 & 0.776 & $0.146 \mathrm{~g}$ & 1.0 & 1.000 & 0.338 & $0.064 \mathrm{~g}$ \\
\hline 0.5 & 2.000 & 0.417 & $0.078 \mathrm{~g}$ & 0.5 & 2.000 & 0.238 & $0.045 \mathrm{~g}$ \\
\hline 0.25 & 4.000 & 0.152 & $0.029 \mathrm{~g}$ & 0.25 & 4.000 & 0.105 & $0.020 \mathrm{~g}$ \\
\hline
\end{tabular}

The plots of Horizontal and Vertical ground response spectra are shown on the next sheet. Also shown on the plot is the horizontal response spectrum that was previously used. 
10t/

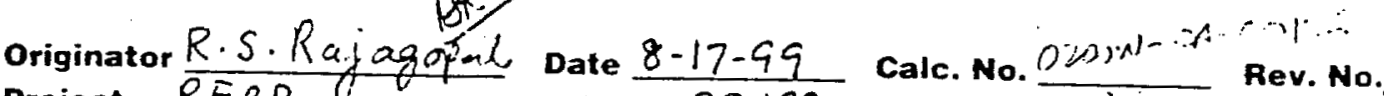

Project RERP Job No. 22192 Checked It

Subject Evaluation of REDOX - North Gallevis Strustave for Pe Luadout Hood Erotection.

Date $1 / 7 \operatorname{lan}^{2}$

Sheet No.

\section{PLOTS OF SEISMIC GROUND SPECTRA (For $10 \%$ Damping)}

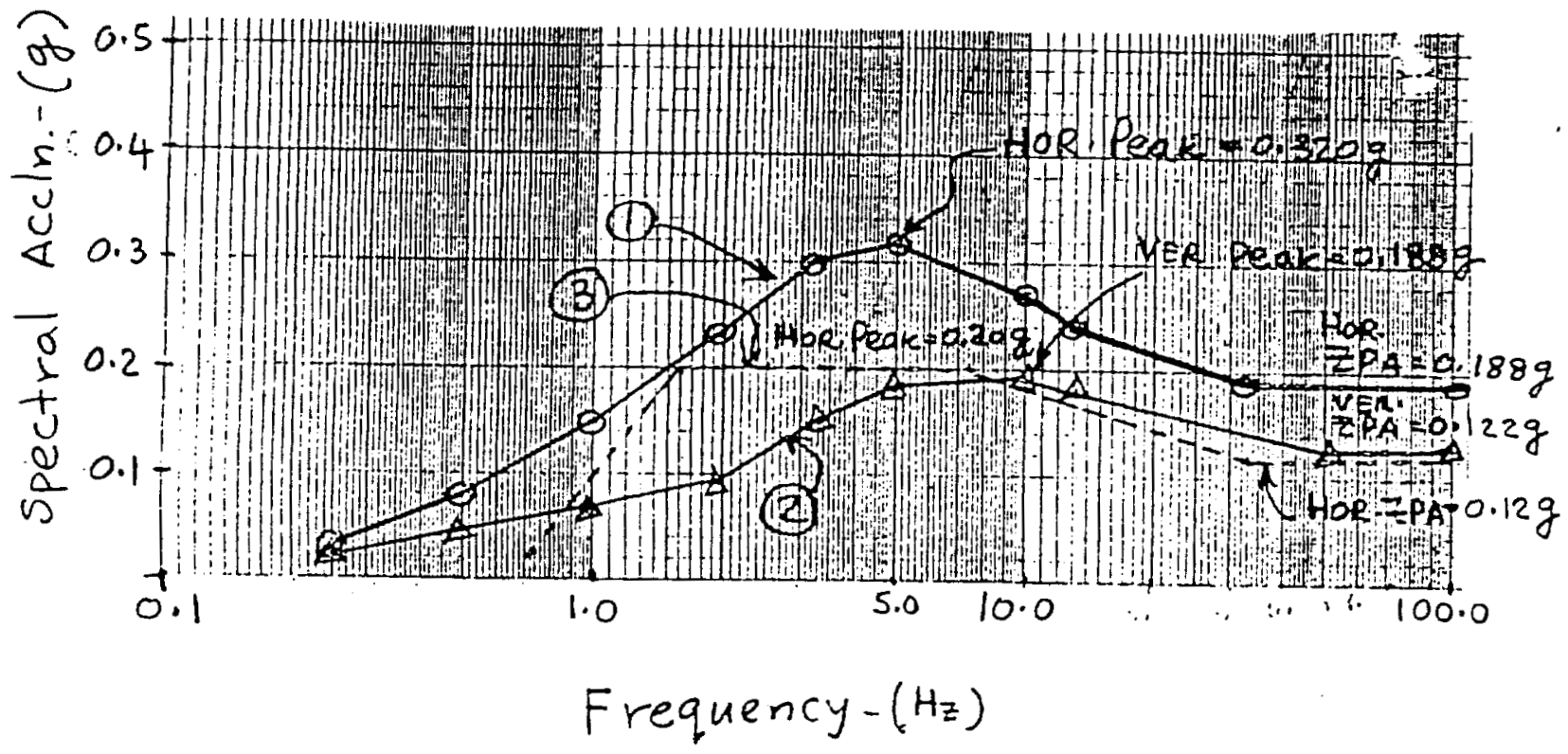

(1) Horizontal Ground Spectrum for
"Existing PC3 structure" in 200w Area.

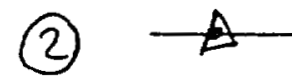
Vertical Ground Spectrum for "Existing PC 3 Structure" in 200w Area.

(3) -... Horizontal Ground Spectrum used in Previous Analysis (Ref. 7) based on Figure 5 of previous Hanford plant Standard SDC 4.1 (Ref.14) 
BHI-01299

Rev. 0

\section{CALCULATION SHEET}

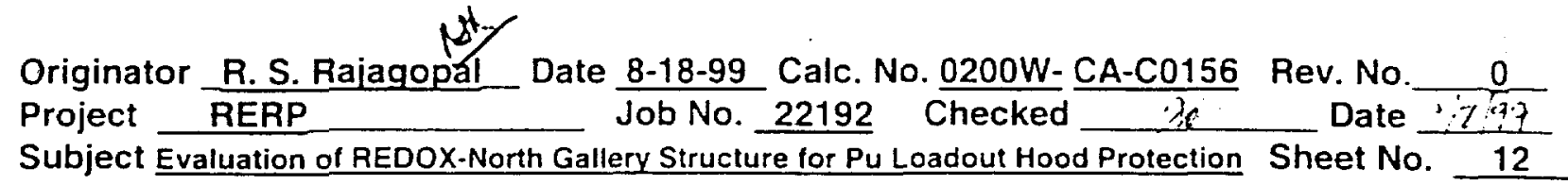

5.0 SEISMIC EVALUATION (Cont'd):

\section{SEISMIC ANALYSIS:}

(a) Seismic Model:

The "GT-Strudl" finite element model used in the previous seismic analysis (Ref. 7) is again used for the calculation of seismic forces and moments in the North Gallery walls and slabs of the REDOX building. The seismic model excerpted from the Reference 7 is included in Attachment $\mathrm{G}$.

(b) Original Model with Original Spectrum (Spectrum Curve 3, Sheet 11):

[Attachment A-Input, Attachment B-Output]

For verification of the model, the analysis was rerun with the same input spectrum as was previously used in Ref 7. The input is included in the Attachment $A$ and the output is included in the Attachment $B$. The results of the previous analysis (Ref. 7) for the North Gallery walls and slabs, with the output shown in the Attachments $B$ are tabulated on the next sheet for comparison. From this comparison it is seen that the output results of the rerun analysis (Attachment B) are same as that of the previous analysis (Ref. 7) as expected.

\section{(c) Corrected Model with Original Spectrum (Spectrum Curve 3, Sheet 11):}

[Attachment C-Input, Attachment D - Output]

During the verification process, however, it was noticed that the vertical coordinate of one of the node points (Node Point no. 11) of the model was not correct. The vertical coordinate of the model was corrected and the analysis was rerun using the same previous spectrum, see Attachment $C$ for the input. The output of the corrected model is shown in Attachment $D$. The results of the corrected model are also compared with the results of the previous analysis (Ref. 7 ) and that of the rerun analysis (Attachment $B$ ) in the table on the next sheet. From this comparison it is seen that the effect of the incorrect coordinate of the node point no. 11 is insignificant, and the moments and shears values from the corrected model, in general, are șlightly lower.

\section{(d) Corrected Model with "Existing PC3 Structures" Spectrum (Spectrum Curve 1, Sheet 11):}

[Attachment $E$ - Input, Attachment F-Output]

The seismic load is based on the response spectra approved by DOE for Hanford site, see Westinghouse report WHC-SD-W236A-TI-001 Rev 1A (Ref 12). The response spectrum for $10 \%$ damping, for "PC3 Existing Structures" in 200W area of the Hanford site is considered for the evaluation. The spectrum has peak spectral value of $0.32 \mathrm{~g}$ and ZPA value of $0.188 \mathrm{~g}$. The North Gallery walls and slabs are assessed for the seismic forces resulting from the spectrum defined above.

The corrected model is used for the present analysis. The input for the present analysis is shown in Attachment $E$, and the output is shown in Attachment $F$. The table shown on the next sheet also includes the results of the present analysis for the North Gallery Walls and Slabs. 
Rev. 0

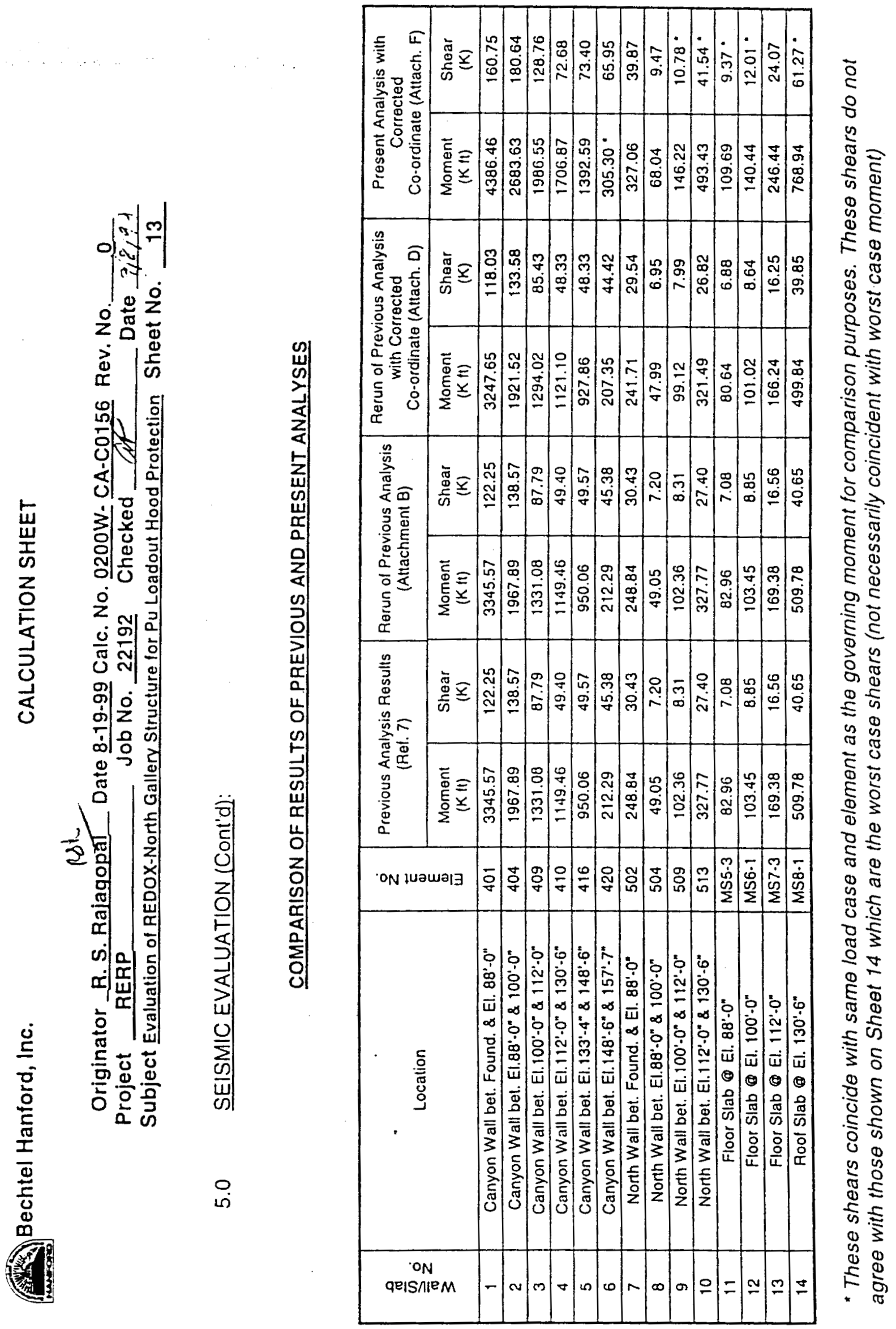


BHI-01 299

Rev. 0

\section{CALCULATION SHEET}

\section{O DOOTH.CA-}

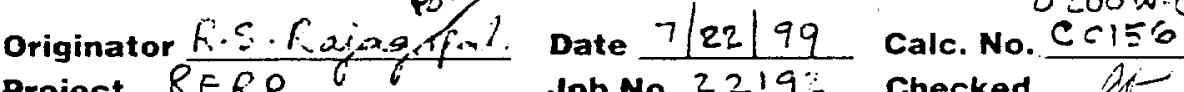
Project RERP Job No. 2219 Checked Af Subject Evalenation of REDOX - North GeMere Structere fir Pu Logtiont Hood Protec....

5.0 SEISMIC EVALUATION (CONTD):$$
\text { s }
$$$$
6
$$$$
7
$$$$
8
$$$$
9
$$
"CAPACITY" VS. "DEMAND" OF NORTH GALLERY WALLS S SLABS FOR SEISMIC LOADS: The Seismic demand are obtainted from "GT STRuOL" outprat shoum in Attachment. .F. .

\begin{tabular}{|c|c|c|c|c|c|c|c|c|}
\hline \multirow{2}{*}{$\begin{array}{l}\text { WALL } \\
\text { OR } \\
\text { SLAB }\end{array}$} & \multirow[t]{2}{*}{ LOCATION } & \multirow{2}{*}{$\begin{array}{l}\text { ELEMENT } \\
\text { NO. INN } \\
\text { FE MODEL }\end{array}$} & \multicolumn{2}{|c|}{$\begin{array}{l}\text { MOMENT. } \\
\text { (Kft./ft width) }\end{array}$} & \multicolumn{2}{|c|}{$\begin{array}{l}\text { SHEAR } \\
(k / F \text {. ridih) }\end{array}$} & \multicolumn{2}{|c|}{$\begin{array}{l}\text { CAPACTTY-DEMAND } \\
: \text { RATIO }\end{array}$} \\
\hline & & & DEMAND & CAPACITY & DEMANS & CAPACITY & MOMENT & SHEAR \\
\hline & $\begin{array}{l}\text { Canjon wall Bet. } \\
\text { Found. \& E. } 88^{\prime}-0^{\prime \prime}\end{array}$ & $401-403$ & $\begin{array}{l}4386 / 18.4 \\
=238\end{array}$ & 234 & $\begin{array}{l}16,0.7 / 18 \cdot 4^{*} \\
=8.7\end{array}$ & 85.7 & $\begin{array}{r}0.983 \\
\times 1.0 \\
\end{array}$ & 9.9 \\
\hline (2) & 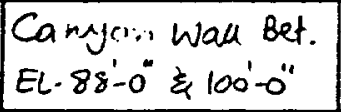 & $404-407$ & $\begin{array}{l}2684 / 18.42 \\
=146\end{array}$ & 234 & $\begin{array}{l}180.5 / 124+2 \\
=9.8\end{array}$ & 85.7 & 1.6 & 8.7 \\
\hline & $\begin{array}{l}\text { Canyon woll Bet. } \\
\text { e. } 100-0 " \text { \& } 11=-0^{\circ}\end{array}$ & 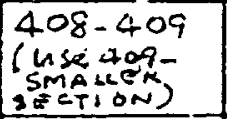 & $\begin{array}{l}1987 / 17 \cdot 42 \\
=108\end{array}$ & 194 & $\begin{array}{l}128.8 / \pi \cdot 42 \\
=7.0\end{array}$ & 71.2 & 1.8 & 10.2 \\
\hline 1 & $\begin{array}{l}\text { Cangon wall tet. } \\
\text { El- } 112^{\prime}-0^{4} \& 133-4^{\prime \prime}\end{array}$ & $410-415$ & $\begin{array}{l}1707 / 18.42 \\
=d_{3}\end{array}$ & 194 & $\begin{array}{l}72 \cdot 1 / 1 i \cdot i+2 \\
=3.9\end{array}$ & $71 \cdot 2$ & 2.1 & 18.3 \\
\hline & $\begin{array}{l}\text { Cangon wall Bef. } \\
\text { E. } 133^{\prime}-4^{\prime \prime}=148^{\prime}-c^{\prime}\end{array}$ & $416-419$ & $\begin{array}{l}1393 / 18 \cdot 42 \\
76\end{array}$ & 32 & $\begin{array}{l}73 \cdot 4 / 10.42 \\
=4.0\end{array}$ & 26.7 & $\begin{array}{l}0.4 \\
(N G) \\
\end{array}$ & 6.7 \\
\hline & $\begin{array}{l}\text { Canygon wan Bet. } \\
\text { Et } 148^{\prime}-6^{4} \approx 157^{\prime}-7^{4}\end{array}$ & $\begin{array}{l}420,421 \\
\xi M R S-14\end{array}$ & $\begin{array}{l}316 / 18 \cdot 42 \\
=17\end{array}$ & 6 & $\begin{array}{l}65.9 / 18.4= \\
=3.6\end{array}$ & 10.9 & $\begin{array}{l}0.35 \\
(N G)\end{array}$ & 3.0 \\
\hline & $\begin{array}{l}\text { North wall Bet. } \\
\text { Fourd. } 2 \text { El. } 80^{\prime}-0^{4}\end{array}$ & $502-503$ & $\begin{array}{l}327 / 18 \cdot 1+2 \\
-18\end{array}$ & 121 & $\begin{array}{l}39.9 / 18.42 \\
=2.3\end{array}$ & 35.7 & 6.7 & 15.5 \\
\hline 1 & $\begin{array}{l}\text { North wab foret. } \\
\text { E1.88 }-0^{4} \neq 100^{\prime}-0^{4}\end{array}$ & $504-506$ & $\begin{array}{l}68 / 18.42 \\
23.7\end{array}$ & 96 & $\begin{array}{l}9.5 / 6.42 \\
=0.5\end{array}$ & $35.8^{\circ}$ & 26.0 & 71.6 \\
\hline & $\begin{array}{l}\text { North wask Bet. } \\
\text { El.100-0" } 112^{\prime}-0^{\prime \prime}\end{array}$ & $507-509$ & $\begin{array}{l}146 / 18.42 \\
=7.9\end{array}$ & 96 & $\begin{array}{l}15.9 / 11.42 \\
=0.9\end{array}$ & 35.8 & $12-1$ & 39.8 \\
\hline & $\begin{array}{l}\text { North wale Bet. } \\
\text { El. } 112-0^{4} \& 130^{\prime}-6^{\prime \prime}\end{array}$ & $510-513$ & $\begin{array}{l}493 / 18.42 \\
=27\end{array}$ & 96 & $\begin{array}{l}49.8 / 18.42 \\
=2.7\end{array}$ & 35.8 & 3.6 & 13.2 \\
\hline & $\begin{array}{c}S\left(a l_{s} \subseteq \varepsilon 1.8 z^{\prime}-0^{\prime \prime}\right. \\
(\text { Floor })\end{array}$ & $\begin{array}{l}M S 5-1, \\
M \leq 5-2 \\
m s 5-3\end{array}$ & $\begin{array}{l}110 / 12.42 \\
=6.0\end{array}$ & 34 & $\begin{array}{l}9.5 / 13.42 \\
=0.5\end{array}$ & 13.3. & 5.7 & 26.6 \\
\hline & $\begin{array}{c}\text { Slal Q El. los'-s } \\
\text { (Fleor) }\end{array}$ & $\begin{array}{l}M S G-1 \\
M S 6-2 \\
M S G-3\end{array}$ & $\begin{array}{l}14 \% / 18 \cdot 42 \\
-7.6\end{array}$ & 43 & $\begin{array}{l}12.2 / 18 \cdot+2 \\
=0.7\end{array}$ & 16.6 & $5 \cdot 7$ & $\{3,7$ \\
\hline & $\begin{array}{c}\text { Slab@El.112.0" } \\
\text { (Floor) }\end{array}$ & $\begin{array}{l}\text { Ms } 7-1, \\
\text { ms } 7: 2, \\
\text { ms }-3.3\end{array}$ & $\begin{array}{l}246 / 18 \cdot 42 \\
=13.4\end{array}$ & 43 & $\begin{array}{l}24 ! / 18.42 \\
=1.3\end{array}$ & 16.6 & 3.2 & 12.8 \\
\hline (14) & $\begin{array}{l}\text { Sh.lr e El.130-C" } \\
\text { (Roof) }\end{array}$ & 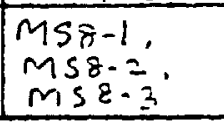 & $\begin{array}{l}769.18 .42 \\
=41 \cdot 7\end{array}$ & 70 & $\begin{array}{l}61.4 / 18.42 \\
=3.4\end{array}$ & 26.2 & 1.7 & 7.7 \\
\hline
\end{tabular}

* Tributary width = 18.42 f. (See sheet 8 i of Ref.?, and sheef Fil of attochment F) 
BHI-01299

Rev. 0

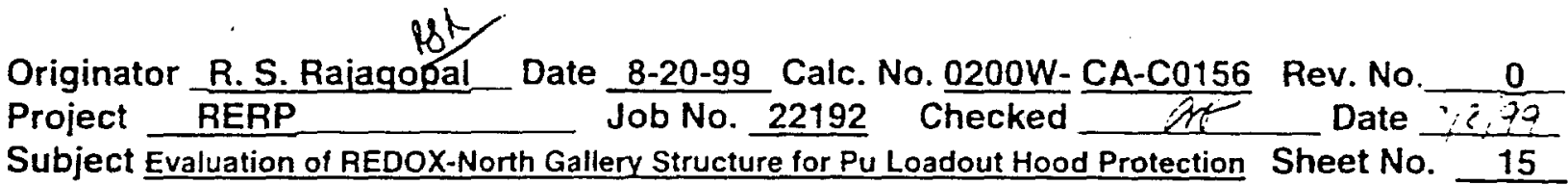
5.0 SEISMIC EVALUATION (Cont'd)

\section{Discussions on the Seismic Evaluation:}

The Capacity-Demand ratio for moments and shears far exceed unity for all walls and slabs except for the 5'-0" thick canyon wall just above the foundation level. For this canyon wall the Capacity-Demand ratio is 0.983 , which is only less than $2 \%$ below unity. It is judged that this slight under capacity is not a concem because of the following reasoning. The seismic model for simplicity does not include the soil-structure interaction effects, and hence the seismic demand on the wall is over estimated. In actuality, the building is deeply embedded below the grade (Grade is at El. 96'-0" and foundation is at El. 73'-3"). There is significant amount of lateral restraint and hence there is no potential for building collapse.

However, the capacity-demand ratio for the walls above El. $133^{\prime}-4^{\prime \prime}$ is far lower than unity and there are no lateral restraints. Hence the walls can form plastic hinge and potentially collapse on the North Gallery roof at EI. 130'-6". The roof slab is evaluated for this potential load drop effect of the collapse scenario in Section 6.0 of this calculation package. 
BHI-01299

Rev. 0

Bechtel Hanford, Inc.

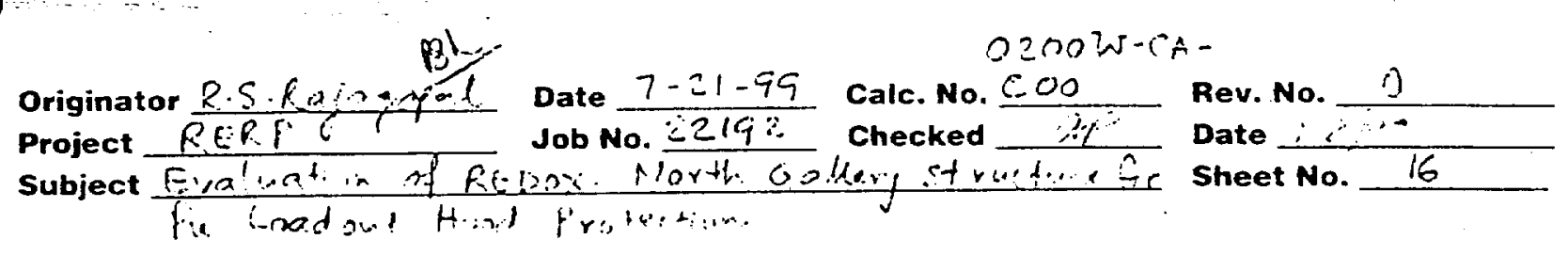

6.0 LOAD DROP EVALUATION

(see sheet 3 for the

POSTULATE L LOAD DROP SCENARIO).

CALCULATION SHEet

$$
02007-5-\hat{A}-
$$$$
\text { Rev. No. } 0
$$$$
\text { Date }
$$$$
E L \cdot 157^{\prime} \cdot 7^{\prime \prime}
$$

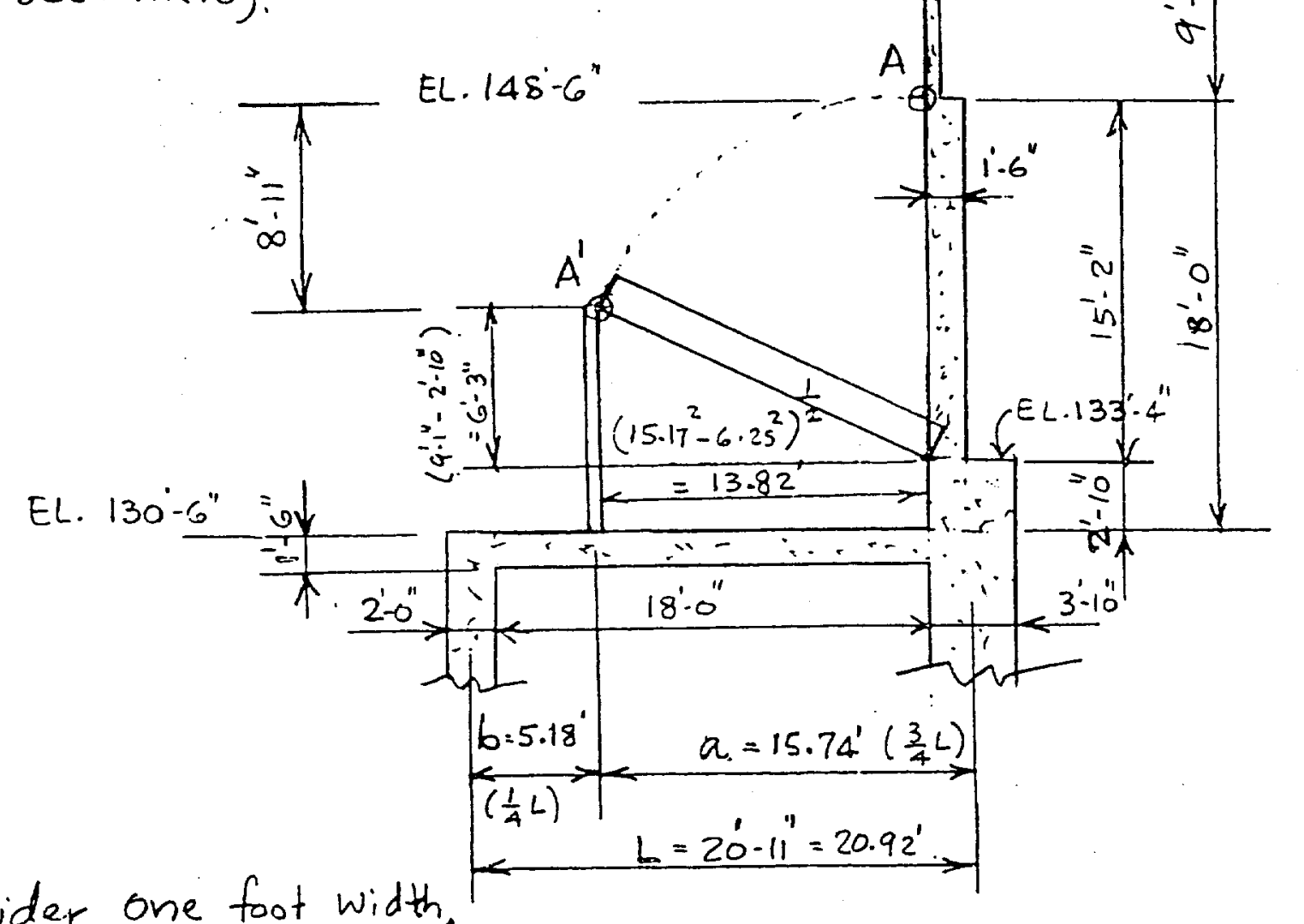

Consider one foot width.

$$
\begin{aligned}
& H=\text { Height of Load Drop }\left(A \text { to } A^{\prime}\right)=8^{\prime}-11^{\prime \prime}=8.92^{\prime} \\
& \begin{aligned}
& W_{m}=\text { weight of Dropped Load }= \\
&=0.15 \mathrm{kcf} \cdot[(0.57)(1.0)(9.08)+(1.5)(1.0)(15.17)] \\
&=0.91+1.71 \\
&=2.62 \mathrm{~K}
\end{aligned}
\end{aligned}
$$

33

34

35

$$
\begin{aligned}
V_{s}=\text { Velocity of Drop. }=\sqrt{2 g H} & =(2 \times 32.2 \times 8.92)^{\frac{1}{2}} \\
& =24.0 \mathrm{ft} / \mathrm{sec}=288.0 \mathrm{in} / \mathrm{sec} .
\end{aligned}
$$

E96120

A-18 
BHI-01299

Rev. 0

Calculation sheet

o?mith.rA

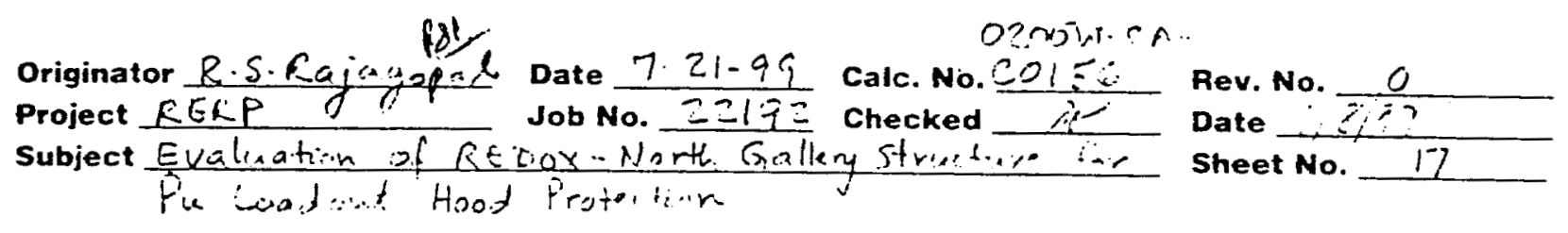

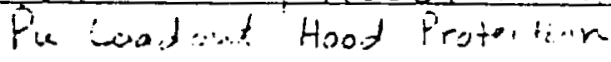

6.0 LOAD DRGP EVALMATION(Cont'd):

LOCAL EFFECT OF LOAD DROP

(Ref: Sect. 2.0 of. Bechtel Design Guide C-2.45, Ref. 10)

Consider the load drop to be of type solid steel falling on reinforced concrete element and use Eq 2-1 of Ref. 10 to determine the thickness for threshold of sealing.

$$
\begin{aligned}
& T_{s}=15.5 \frac{W^{0.4} V_{s}^{0.5}}{\sqrt{f_{c}^{1}} D^{0.2}} \\
& W=2620 \mathrm{lbs} \\
& V_{s}=24 \mathrm{ft} / \mathrm{sec} . \\
& f_{c}^{\prime}=5625 \mathrm{Psi}
\end{aligned}
$$

$D^{C}$. Equivalent missile diamenter inches

$$
\begin{aligned}
A_{i}=\text { Area of inciting } & =12 \times 8^{\prime \prime}=96 \mathrm{in}^{2} \\
D & =\sqrt{\frac{4 A i}{\pi}}=\sqrt{\frac{(4)(96)}{\pi}}=11.06 \mathrm{in} \\
\therefore \quad T_{s} & =\frac{(15.5)(2620)^{0.4}(24)^{0.5}}{(5625)^{0.5}(11.06)^{0.2}} \\
= & \frac{(15.5)(23.3)(4.9)}{(75)(1.61)}=14.7^{\prime \prime}
\end{aligned}
$$

Appendix $B$, Section 2.1. I of Ref. 10 recommends increasing value of $T_{5}$

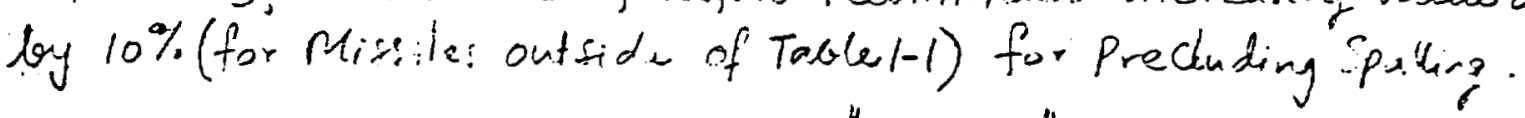

33

$$
\therefore T_{a}=(1.1)(14.7)=16.2^{4}<18^{\prime \prime} \text { slab } \therefore \text { No Spall }
$$
Since "spelling" governs over "Perforation", then there is additionally No
perforation of the roof Slab.

ES6 1200:

A-19 
BHI-01299

Rev. 0

CALCulation SHEet

$$
0200 T 5-C A-
$$

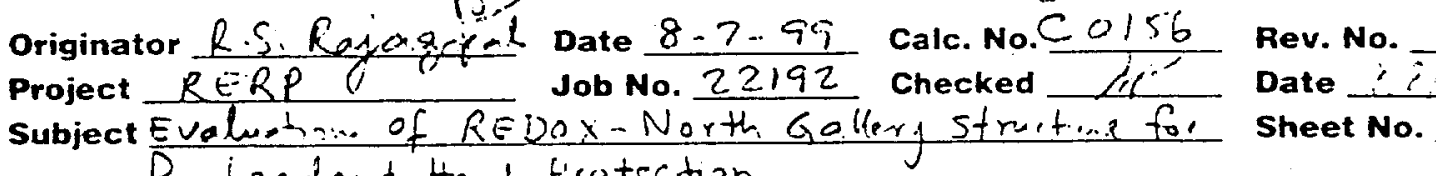

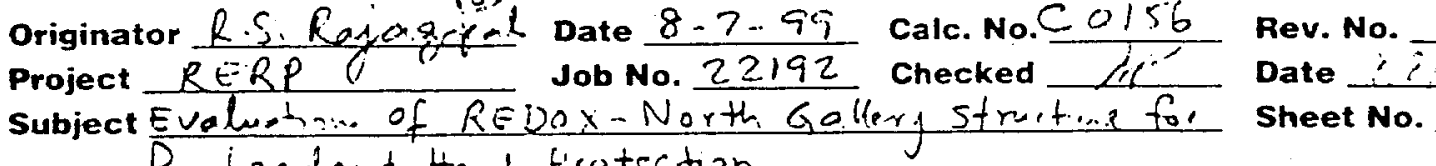

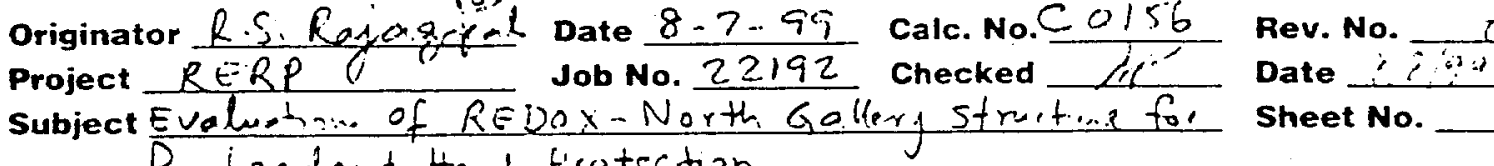

Pu Lookout Hood Protection

6.0 LOAD dRop Evaluation (contd)

STRUCTURAL RESPONSES DUE TO LOAD DROP

(Ref: Sects. 3.0 \& 4.0 Bechtel Design Guide C. 2.45 , Ref. 10)

Determination of Effective mas of Slab a EL 130.6" :

$$
\begin{aligned}
& \begin{array}{l}
M_{e}=k\left[\frac{T_{n}}{2 \pi}\right] \\
=\frac{2 \pi}{C_{n}}\left(\frac{M L^{4}}{E I_{e}}\right)^{\frac{1}{2}}
\end{array}
\end{aligned}
$$

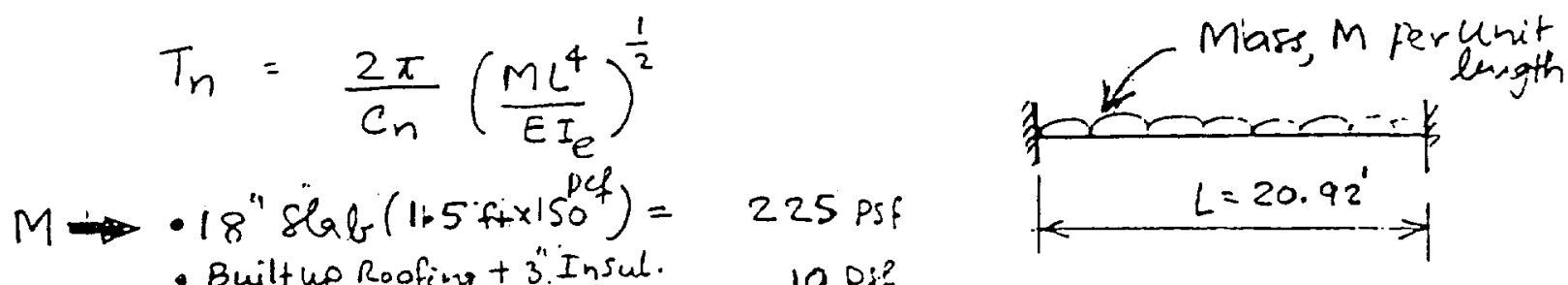

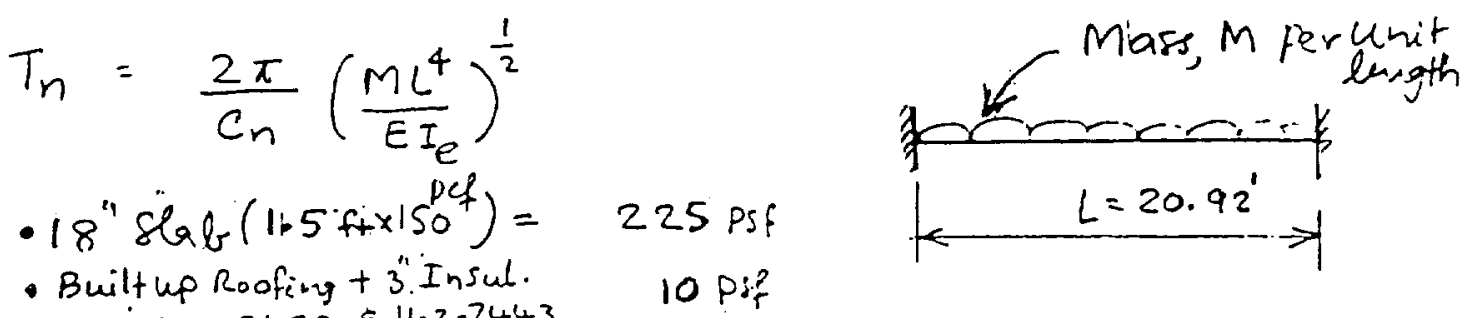

(See Digs $H-2-7472$ \& H-2.7443

16

$$
=8+2=10 \text { psf) }
$$

17

For $1^{\prime}$ width of slab. $\quad w=235 \mathrm{lbs} / \mathrm{ft}=\frac{0.225}{12}=0.0196 \mathrm{i} / \mathrm{in}$

19

20

$$
\begin{aligned}
& M=\frac{h r}{g}=\frac{0.0192}{386.4}=\frac{0.0000507}{\mathrm{ksa} / \mathrm{sin}^{2}} \\
& C_{n}=22.4 \text { Fixed. Fixed Case (Table 4.5 Ref.10). L=20.92' } \\
& E=4275 \mathrm{ksi} \text { (Dynamic) }
\end{aligned}
$$

$\therefore$ Effective Moment of Inertia, $I_{e}$ (Sect. 4.2, Pages $45 \dot{5} 46$ Ref. 10 )

$$
\begin{gathered}
I_{e}=\left(\frac{M_{c r}}{M_{a}}\right)^{3} I_{g}+\left[1-\left(\frac{M_{c r}}{M_{a}}\right)^{3}\right] I_{c} \leqslant \frac{1}{2}\left(I_{g}+I_{c}\right)\left(E_{q .4 .2}\right. \text { Ref. 10) } \\
I_{g}=\frac{6 a^{3}}{12}=\frac{(12)(18)^{3}}{12}=5832 \mathrm{in}^{4}
\end{gathered}
$$

30

$3 t$

33

$I_{c}=F^{\prime} I_{g} \quad$ consider mid spare, $\rho_{t}: \rho_{b}=\frac{\left(A_{s}=1.33\right)}{(12)(16.29)}=0.0068$

$$
n=\frac{E_{s}}{E_{c}}=6.8, P+l_{b}=1.0
$$

$F^{\prime}=0.25$ from Fig.4-1 of Ref. 10

$$
\therefore I_{r_{1}}=(0.25)\left(5820.1458 \mathrm{in}^{4}\right.
$$

E96120C

A-20 
BHI-01299

Rev. 0

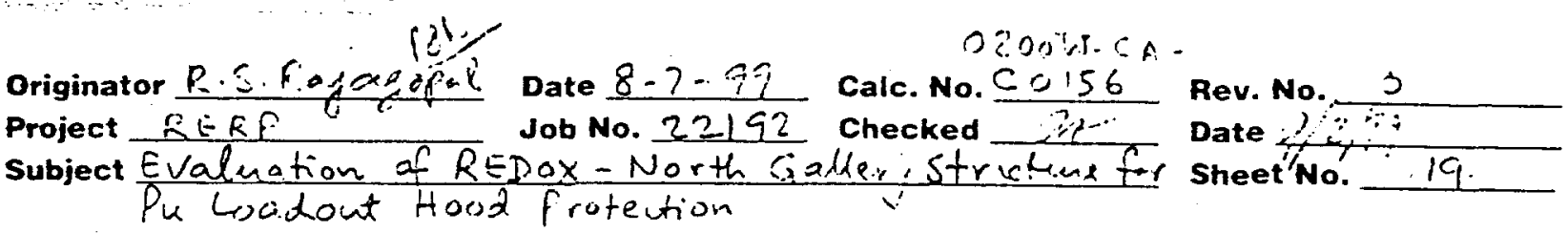

$\begin{array}{ll}\therefore & 1 \\ \therefore \quad & 2 \\ & 3\end{array}$

5

6

7

8

9

10

11

12

13

14

16

17

18

19

20

21

22

23

24

25

26

27

28

29

30

31
Bechtel Hanford, Inc.

CALCulation SHEET

Structural response dUE to load drop (CONT i)

$$
\begin{aligned}
M_{C r} & =1.25 b t^{2} \sqrt{f_{c}^{\prime}} \\
& =(1.25)(12)(18)^{2} \sqrt{5625}=364.5 k^{\prime \prime}=30.4 k f r
\end{aligned}
$$

$M_{a}=M_{u}$ for merubers defisraing Narticalleg

$$
M_{u}=\phi A_{s} f_{y}\left(d-\frac{a}{2}\right) .\left(E_{q} \cdot 4-3 \operatorname{Ref}, 10\right)
$$

Area of Reinforcement, $A_{5}$ :

Roof Slab. El.130'-6"

- (e) Slab mid span @ bottom 1中@ " $^{n} \mathrm{c} . \quad A_{S}=1.33 \mathrm{in}^{2}$

- @ Sab End @ top -

$1^{\prime \prime} \phi @ q^{4} c+1 " \phi @ q^{\prime \prime} c$.

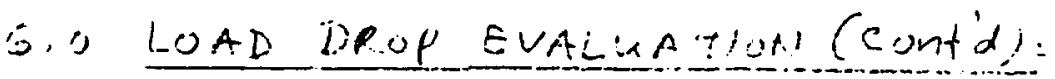

$A_{s}=(2)(1.33)=2.66 \mathrm{in}^{2}$

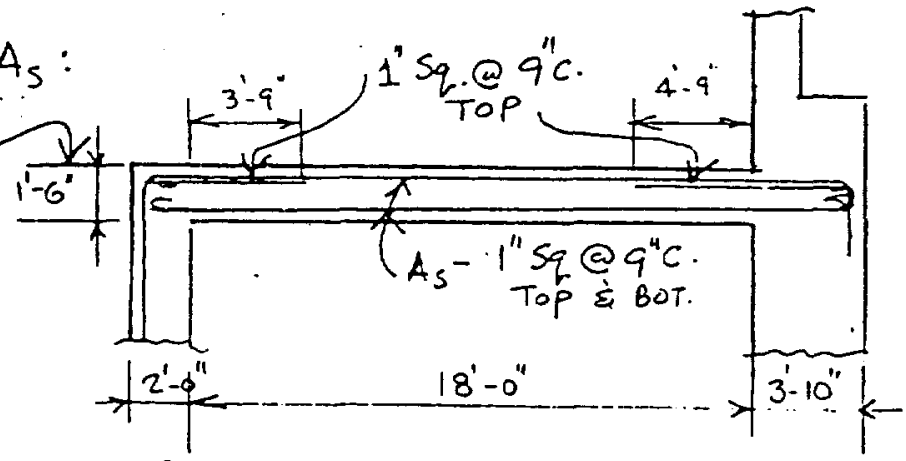

Ref: Dug. H-2-7757

Dwi. $H-2-8289$ Sect. $168-168$

Dig. $1-2-8376$ Sect. $180-180$ calculation of $M_{u}$ :

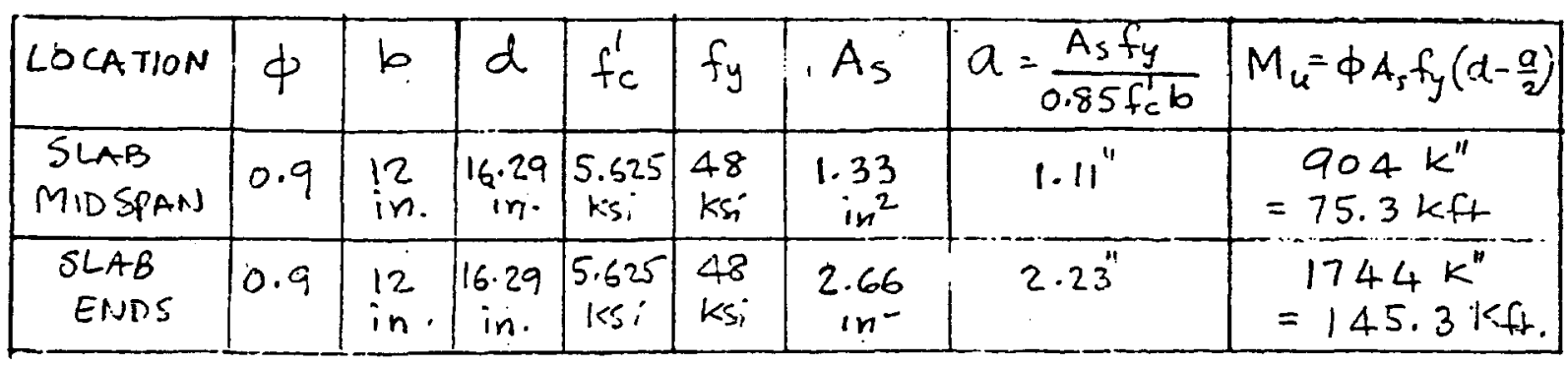

33

34

35

36

$M_{a}=M_{u}$ O mid span, pecan rid spar. get: oxcitex for dynamic loads. $=75.3 \mathrm{kfr}$

$$
\frac{M_{c r}}{M_{a}}=\frac{30.4}{75.3}=0.40 .4
$$

E9612005

A-21 
BHI-01299

Rev. 0

Calculation SHEET

Pi. DZ.OOTH-C.A -

Originator R.?.Rjogofal Date $8-8.99$ Talc. No. $\frac{20156}{29}$ Rev. No.

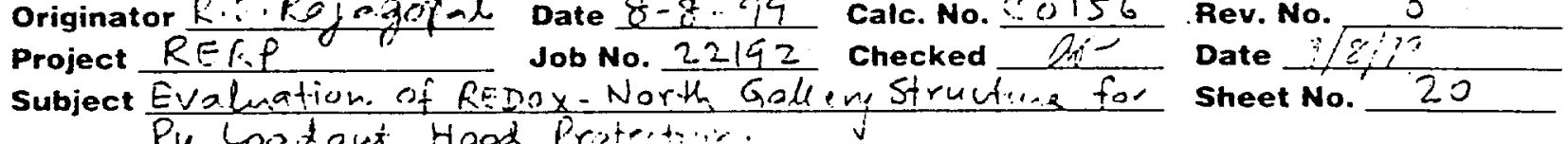
Pu Looitow' Hood Pristertin.

6.0 LOAD DR OF EVALUA P.N (Contd).

STRUCTURE!, RESPONSE DUE TO LOAD DROP (CONTO

$$
\begin{aligned}
I_{e} & =(0.404)^{3}(5832)+\left[1-(0.404)^{3}\right](1458) \\
& =385+1362=1747 \mathrm{in}^{4}+\frac{1}{2}(5832+1458)=3645 \mathrm{in}^{+} \\
\frac{1}{2}\left(I_{g}+I_{c}\right) \cdot \text { Governs } & =\frac{2 \pi}{22.4}\left[\frac{(0.0000507)(20.92 \times 12)^{4}}{(4275)(1747)}\right]^{\frac{1}{2}} \\
\therefore T_{n} & =\frac{2 \pi}{22.4}(0.02696)^{\frac{1}{2}}=0.0461 \mathrm{sec} .
\end{aligned}
$$

16

Compute effective mass:

$$
M_{e}=k\left[\frac{T_{n}}{2 \pi}\right]^{2} \quad\left(E_{q} 3.1, \operatorname{Ref}, 10\right)
$$

(Refl AIsc Manual, P. 2-30l, Case 17)

$$
\begin{aligned}
& \Delta=\frac{P a^{3} b^{3}}{3 E I L^{3}} \\
& K=\frac{P}{\Delta}=\frac{3 E I L^{3}}{\left(\frac{1}{4} L\right)^{3}\left(\frac{3}{4} L\right)^{3}}
\end{aligned}
$$

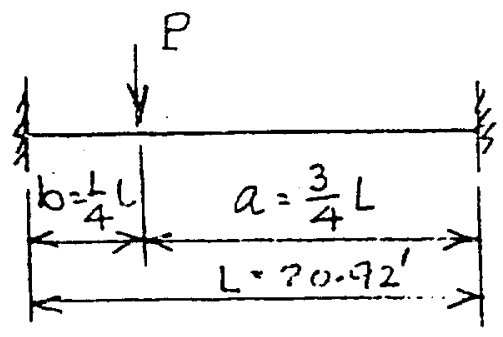

$$
\begin{aligned}
& K=\frac{455.1 E I}{L^{3}} \\
& =\frac{(455.1)(4275)(1747)}{(20.92 \times 12)^{3}}=\frac{214.84 \mathrm{k} / \mathrm{in} .}{} \\
& \therefore M_{2}=(214.84)(0.0461 / 2 \pi)^{2}=0.0116 \mathrm{ksec}{ }^{2} / \mathrm{in} \\
& \text { Lower bound } M_{2}=M_{6}(D+2 t)
\end{aligned}
$$

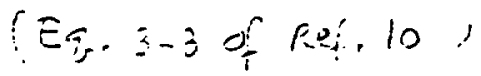

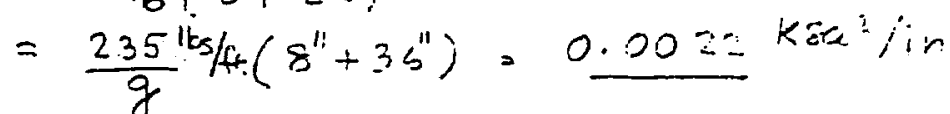

30

31

33

E961206

A-22 
BHI-01299

Rev. 0

PSty Brooli-CA.

CALCULATION SHEET

Bechtel Hanford, Inc.

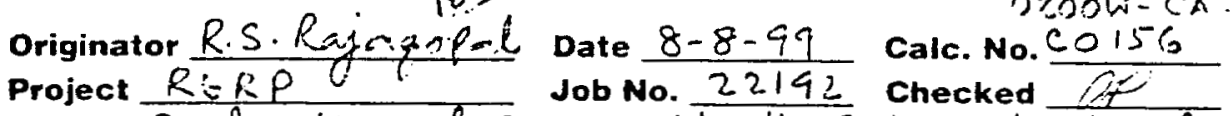
Subject Evaluation of R.EDOX-North. Giokory Strueture for

$$
\begin{aligned}
& \therefore \quad 6.0 \text { LOAD DRof Evalua rlun (Conidj. }
\end{aligned}
$$

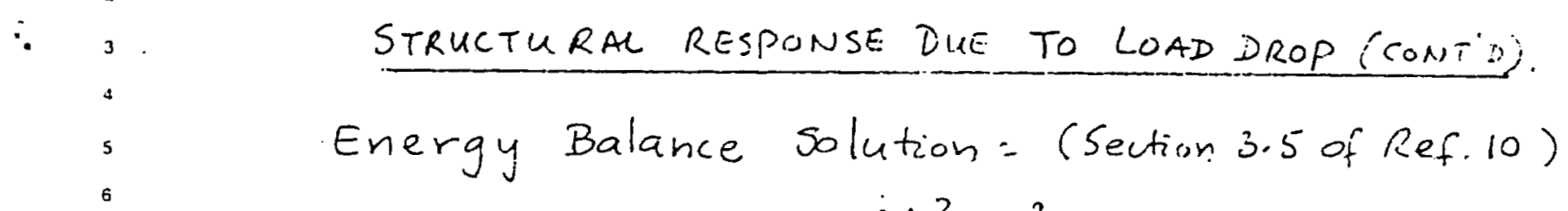

$$
\begin{aligned}
& \text { Kinetic Energy, } E_{S}=\frac{M_{m}^{2} V_{s}^{2}}{2\left(M_{m}+M_{e}\right)} \quad\left(E_{f} \cdot 3-16,6.1 .10\right)
\end{aligned}
$$

For kirietic evergy of tha Sigitem after a plastic impaet

$$
\begin{aligned}
& V_{s}=24.0 \mathrm{fr} . / \mathrm{scc}=288 \mathrm{in} / \mathrm{sec} \\
& M_{e}=0.0116 \mathrm{ksce} / \mathrm{in} . \\
& M_{m}=\left[\left(q^{\prime}-1^{4} \times 8^{*} \times 150^{p(f)}\right)+\left(\frac{15^{\prime} \cdot z^{\prime \prime}}{2} \times 18^{4} \times 150 p \leftarrow\right)\right] / g \\
& =\left(0.91^{k}+1.71^{k}\right) / 386.4-0.0068 \mathrm{ksce} / \mathrm{in} \\
& E_{s}=\frac{(0.0068)^{2}(288)^{2}}{(2)(0.0068+0.0116)}=104.22 \mathrm{kin} . \\
& X_{e}=\frac{R a^{3} b^{3}}{3 E I L^{3}}=\frac{R L^{3}}{455.1 E I} \\
& \operatorname{My} \downarrow^{R} \\
& M_{u}^{+}=\frac{R a b}{l}-M_{i s}^{-} \\
& R=\frac{\left(M_{u}^{+}+M_{u}^{-}\right) L}{a b}= \\
& =\frac{\left(M_{u}^{+}+M_{u}^{-}\right)(1)}{\left(\frac{1}{4} L\right)\left(\frac{3}{4} L\right)}=\frac{16\left(M_{u}^{+}+M_{u}^{-}\right)}{3 L}
\end{aligned}
$$

E9612005

A-23 
BHI-01299

Rev. 0

CALCULATION SHEET

(ai)

O2OOTHECA.

Originator R.S.Rgiagofr-x Date $\frac{8-\varepsilon-99}{2-219}$ Call. No. 0156 Rev. No. o

Project RERP Job No. 3.2192 Checked

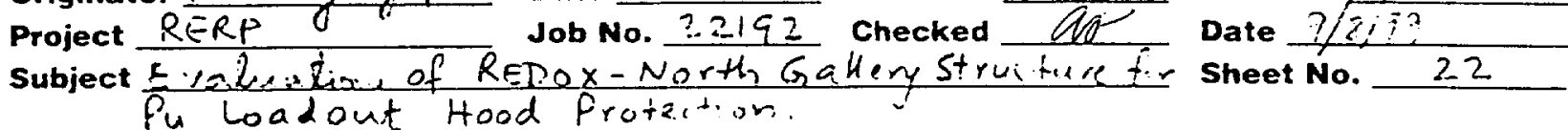

Pu Loadout Hood Protzition.

6.0 LOAD DROP EVALUA Il un (contd):

STRUCTURAL RESPONSE DUE TO LOAD DROP (CONTD)

$$
\begin{aligned}
M_{u}^{+} & =75.3 \mathrm{kfr} . \quad M_{u}^{-}=145.3 \mathrm{kft} \\
R & =\frac{(16)(75.3+145.3)}{(3)(20.92)}=56.2 \mathrm{~K} \\
X_{e} & =\frac{R L^{3}}{455.1 E I_{e}}=\frac{(56.2) i(30.92 \times 12)^{3}}{(455.1)(4275)(1747)}=0.261^{\prime \prime}
\end{aligned}
$$

$X_{0}=$ Deflection due to other loots is., dead load and soy load of $235^{\# / 1}$

$$
\begin{aligned}
x_{0} & =\frac{W L^{4}}{384 E I}=\frac{(0.235)(20.72 \times 12)^{4}}{(384)(4275)(1747)}=\underline{0.027^{\prime \prime}} \\
X_{m} & =\frac{E_{s}}{k\left(x_{e}-x_{0}\right)}+\frac{x_{e}+x_{0}}{2} \quad x_{m}>x_{e}\left(E_{q} .3-20, \rho_{0} f 10\right) \\
& =\frac{104.22}{(214.84)(0.251-0.027)}+\frac{(0.261+0.027)}{2} \\
& =2.073+0.144=2.22^{\prime \prime}>x_{e}(0 k)
\end{aligned}
$$

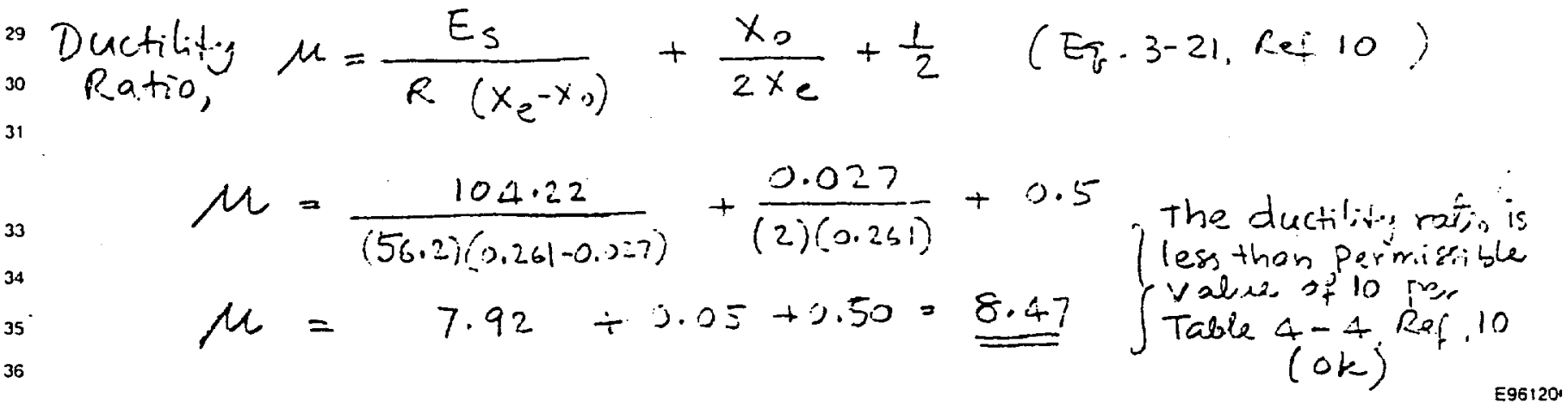

A-24 
BHI-0!299

Rev. 0

Bechtel Hanford, Inc.

pis.

Originator R.S. Kajajt.

Project RGR
CALCULATION SHEET

$$
\text { O200UV. CA }
$$

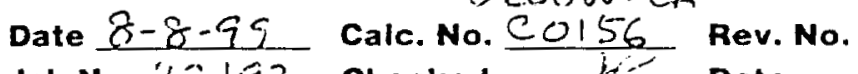
Job No. "219? Checked h- Date

Pu Loadesint Hood Protection

$\begin{array}{ll}\therefore & 1 \\ & 2 \\ & 3\end{array}$

5

5

7

8

9

10

11

12

13

14

6.0 LOAD DROP EVALUATION (Cont'A)

STRUCTURAL RESPONSE DUE TO LOAD DROP (CONTD):

The coripied values of ductility ratio $\mu=8.61$ is less than the permissible value of $\mu=10$ !"r Table 4-4 of Ref 10.

However, to better assert: 112 ductility of the roof Hab, perform. ingplar rotation, check per equation 4-2 of Ref 10 .

Peri Eq 4.: of lief. 10 upper livings of plastic hinge rotation, $r_{\theta}$ is

$$
\begin{aligned}
& r_{\theta}=0.0065 \frac{d}{c} \leq 0.07 \\
& a=1.11^{4} \text { (shes! } 19 j \\
& f_{c}^{\prime}=5625 \text { ps; }
\end{aligned}
$$

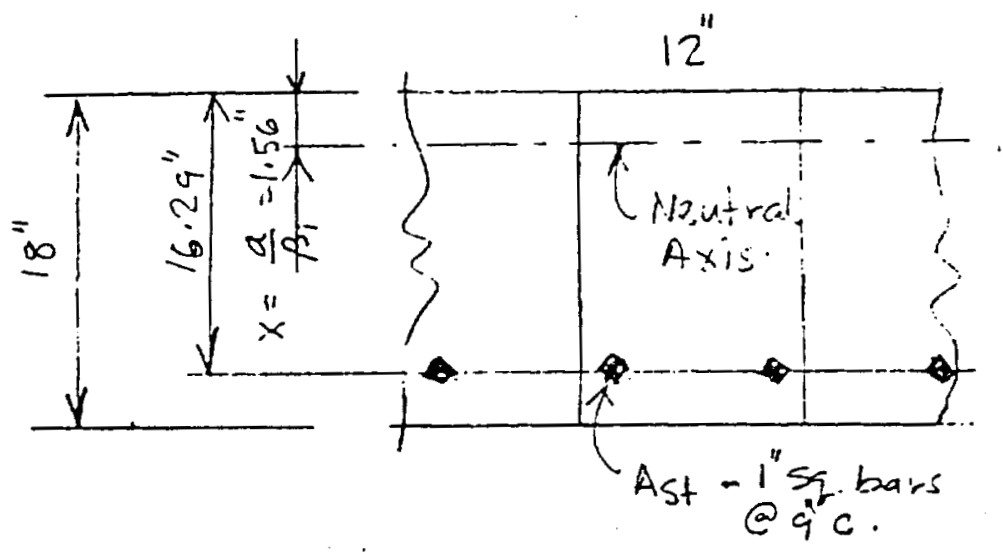

$$
\begin{aligned}
\beta_{1} & =0.85-0.05\left(\frac{f_{c}^{\prime}-4000}{1000}\right) \geqslant 0.65 \\
& =0.85-0.05\left(\frac{565-4000}{1000}\right)=0.77
\end{aligned}
$$

Neutral $f: x=\frac{a}{\beta_{1}}=\frac{1.1}{0.77}-1.44^{\circ}$

$$
d=16.29^{\circ} \quad c=x=1.44
$$

$\left(\operatorname{Rei} \cdot 2 \in E_{i} \cdot 3 \cdot 4-4\right)$

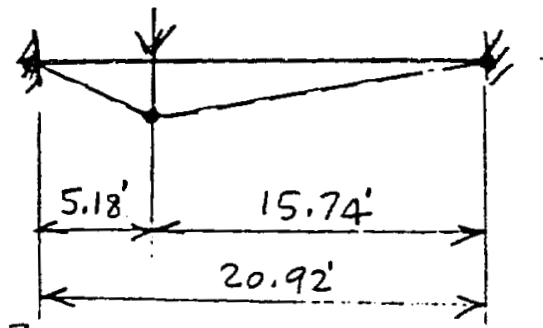

$\therefore r_{\theta}=(0.0065)\left(\frac{16.29}{1.44}:=0.0735\right.$ us? 0.07

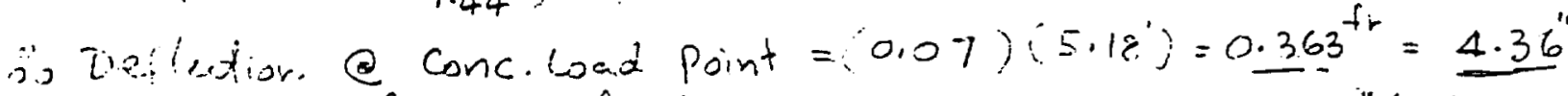

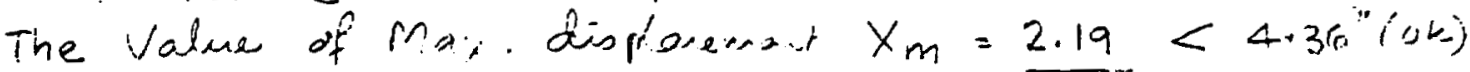
$\therefore$ CAPACITH-DEMAND RATIO $=\frac{4.36}{2.19}=1.99$ (OK)

E9612009

A-25 


\section{Bly}

Originator R. S. Rajagopai

Date 8-20-99

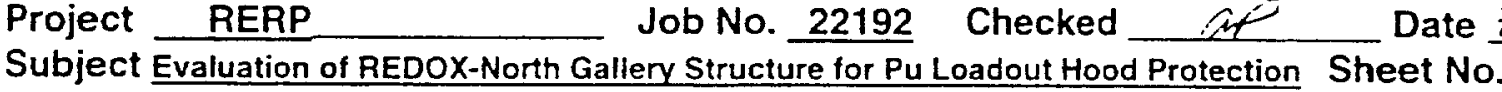

No. $0200 W-$ Checked

CA-C0156

Rev. No. Date $\sqrt[3 / 2 i 3 ?]{2}$

24

- Seismic Demand / Capacity Ratio, $r_{s}$ :

- Horizontal Seismic Load

Maximum Moment $=41.7 \mathrm{Kft}$. (Sheet 14)

Maximum Moment Capacity $=\underline{70.0} \mathrm{Kft}$. (Sheet 14)

Horizontal Seismic Demand / Capacity Ratio $=(41.7) /(70.0)=\underline{0.60}$

\section{- Vertical Seismic Load}

Roof load, $w=235 \mathrm{lbs} / \mathrm{ft}$ (Sheet 18), Span $\mathrm{L}=\underline{20.92} \mathrm{ft}$ (Sheet 18)

Vertical seismic spectral peak acceleration $S_{a}=\underline{0.188 \mathrm{~g}}$ (Sheet $\mathrm{s} 10$ \& 11)

(Conservatively use this vertical acceleration for computation of maximum moment for vertical seismic loads. This is based on the assumption the REDOX building structure is vertically rigid with massive walls, but, the roof slab is not vertically rigid)

Maximum Moment $=(w)\left(1+S_{\mathrm{a}}\right)(\mathrm{L})^{2} /(12)=(0.235)(1.188)(20.92)^{2} /(12)=10.2 \mathrm{Kft}$. Maximum Moment Capacity $=\underline{70.0} \mathrm{Kft}($ Sheet 14$)$

(Note that, maximum moment at the ends with rebar cross section at the mid-span is considered for conservative evaluation. Note that the rebar cross section at ends are higher than at the mid-span which add to the conservatism)

$$
\text { Vertical Seismic Demand } / \text { Capacity Ratio }=10.2 / 70.0=\underline{0.15}
$$

- Adding the Horizontal and Vertical Seismic Demand / Capacity Ratios by absolute sum method, $r_{s}=0.60+0.15=\underline{0.75}$

- Load Drop Demand / Capacity Ratio,

- Load Drop Capacity / Demand Ratio = 1.99 (Sheet 23)

- Load Drop Demand / Capacity Ratio = Reciprocal of the above

$$
n=1 / 1.99=\underline{0.50}
$$

(Conservatively the Demand / Capacity ratio is considered at the load drop point)

- Combined Seismic and Load Drop Demand / Capacity Ratio, r:

Since seismic and Load drop are not concurrent events, combine by Square Root of the Sum of the Squares method.

$$
r=\left[\left(r_{s}\right)^{2}+\left(r_{1}\right)^{2}\right]=\left[(0.75)^{2}+(0.50)^{2}\right]^{1 / 2}=\underline{0.90}<\underline{1.00}(\mathrm{OK})
$$




\section{CALCULATION SHEET}

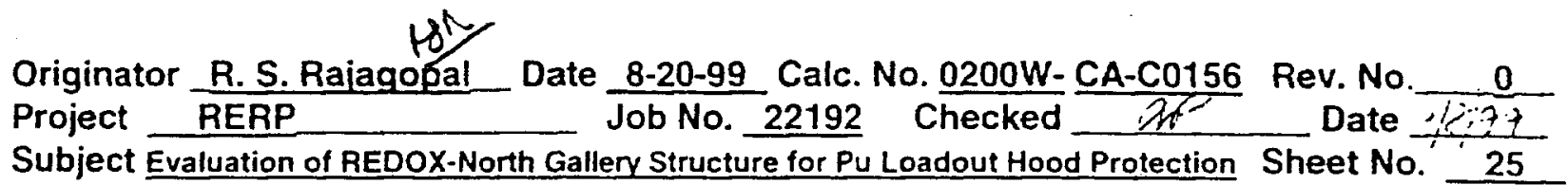

SUMMARY AND CONCLUSIONS:

The Pu Loadout Hood is located on the floor at El. 88'-0" towards the west end of the North Sample Gallery in the REDOX building. To support the safety evaluation of the Pu Loadout Hood, a seismic evaluation of the REDOX building North Gallery was performed. The following paragraphs provide a summary of the seismic evaluation and conclusions.

- The seismic model for the REDOX building developed by Pete Carrato in his report (Ref 7), dated January 1997(CCN 043500) was used.

- The seismic forces are based on an input ground acceleration spectrum for $10 \%$ damping for "Existing PC3 Structures" in 200 West area of Hanford site [(Ref. Westinghouse report WHCSD-W236A-T1-001 Rev 1A (Reference 12)]. The horizontal spectrum has a peak spectral value of $0.32 \mathrm{~g}$ and ZPA of $0.188 \mathrm{~g}$.

- The current seismic evaluation indicate that the walls and slabs of the North Gallery have adequate structural strength to withstand the above seismic forces, except the North Canyon walls above the crane rail El. 133'-4". The north canyon walls can potentially form plastic hinges and collapse on the North gallery roof at El. 130'-6".

- The North Gallery roof (EI. 130'-6") has been evaluated for the above potential load drop effects of the north canyon walls collapse scenario. The evaluation indicates that the roof slab at El. $130^{\prime}-6$ " is structurally adequate to withstand the load drop effects simultaneously with horizontal and vertical seismic forces.

- The load drop does not affect the Pu Loadout Hood situated at El. $88^{\prime}-0^{\prime \prime}$ which is covered by the roof slab at EI. 130'-6", and, other floor slabs at El. 100'-0" \& 112'-0".

Based on the above discussions, it is concluded that the Pu Loadout Hood in the North Gallery of the REDOX building is adequately protected against the effects of seismic forces and the effects of potential load drop scenario. 


\section{CALCULATION SHEET}

\section{8t}

Originator R. S. Rajagopal Date 8-8-1999 Calc. No. 0200W- CA-C0156 Rev. No.

Project RERP Job No. 22192 Checked Date $\frac{.0}{79}$

Subject Evaluation of REDOX-North Gallery Structure for Pu Loadout Hood Protection Sheet No. 26

\subsection{REFERENCES:}

(1)
UBC-1997 "Uniform Building Code", Volume 2 Structural Engineering Design Provisions C. K. Wang and C. G. Salmon "Reinforced Concrete Design" Fourth Edition, Harper \& Row. Publishers, New York

$\mathrm{ACl}$ 318-95 "Building Code Requirements for Structural Concrete (ACI 318-95) and Commentary (ACI 318R-95)

AISC-Manual of Steel Construction (ASD) $-9^{\text {th }}$ Edition

HW-4301 "Specification for Reinforcing Steel for Concrete"

HW-4302 “Specification for Forming. Placing. Finishing. \& Curing of Plain \& Feinforced Concrete”

P. Carrato “Redox Building Seismic Analysis” January 1997. CCN- 043500

BHI Calculation 0200W-CA-C0027 Rev 0 "Load Drop Evaluation of 202-S Canyon Roof Structure" February 1997.

BHI Calculation 0200W-CA-C0033 Rev 0 "Redox (202 S)- Combined Seismic and Load Drop Effects on Cell Covers" December 1997.

Bechtel Design Guide C-2.45 Rev O "Design of Structures for Tornado Missile Impact" April 1982

BHI Calculation 0000X-CA-G0001 Rev 0 "Ground Response Spectra for PC3 Structures" December 1997

Report WHC-SD-W236A-TI-002 Rev 1A “Probabilistic Seismic Hazard Analysis DOE Hanford Site, Washington" by Ann M. Tallman for Geomatrix Consultants Inc. 1996 / 1997.

DOE Standard DOE-STD-1020-94 (April 1994), Change Notice \# 1, January 1996 “Natural Phenomena Hazards Design and Evaluation Criteria for DOE Facilities"

Hanford Plant Standards- Design Criteria Standards: SDC-4.1 “Design Loads for Facilities” Rev 12, (Page 32, Figure 5) 
BHI-01299

Rev. 0

\section{1)}

Originator R.S. Rajagopal Project RERP

Subject Evaluation of REDOX-North Gallery Structure for Pu Loadout Hood Protection

10.0

LIST OF DRAWINGS:

Note: The drawings are too numerous to list for the REDOX building. Figure 8 of Reference 8 provides a summary of the list of Architectural and Structural drawings that are pertinent.. However the following list provides a list of drawings that are relevant for this calculation package.

- H-2-7443 Structural Details Steel Truss No. 1 Canyon

- H-2-7472 Arch. Cross Section C13-C13 on East End and North \& South Service area

- H-2-7474 Arch. Cross Section C14-C14 thru Waste Line Tunnel Galleries ...

- H-2-7475 Arch. Cross Section C15-C15 thru Cells Galleries on West End...

- H-2-7726 Structural Concrete- Plán-Sample Gallery \& AQ Make up West End of Canyon

- H-2-7728 Structural Concrete- Plan-Pipe Gallery \& AQ Make up West End of Canyon

- H-2-7756 Structural Concrete- Plan-Operating Gallery \& AQ Make up West End of Canyon

- H-2-7757 Structural Concrete- Plan- Cab Gallery \& AQ Make up West End of Canyon

- H-2-7782 Architectural Index Sheet

- H-2-7783 Structural Index Sheet

- H-2-7926 Structural Concrete- Details- Foundation - Canyon Area-Sheet \# 1

- H-2-7928 Structural Concrete- Plan-Storage Gallery \& Canyon Foundation West End of CN

- H-2-7929 Structural Concrete- Longitudinal Section- Foundation-West End of Canyon

- H-2-8109 Arch. Exp. Joints \& Flashing Details

- H-2-8289 Structural Concrete- Wall Sections Canyon \& Silo Area Sheet \# 1

- H-2-8376 Structural Concrete- Wall Sections Silo Area Sheet \# 3

- H-2-8391 Structural Concrete- Plan, Sect.,- Details N. Sample Gallery Level West End CN Area 
BHI-01 299

Rev. 0

A-30 
BHI-01299

Rev. 0

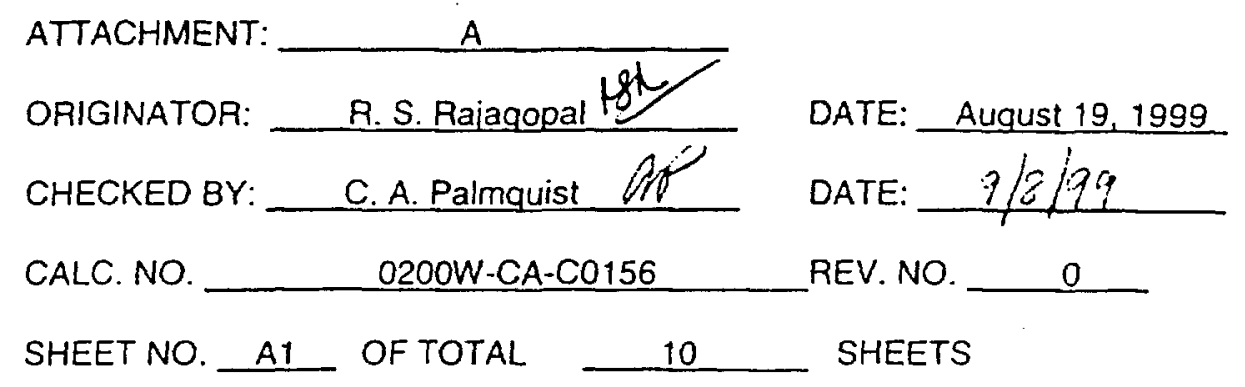

\section{ATTACHMENT "A"}

REDOX (Original "GT Strudl" Model) Input for Seismic Analysis (Using Original Ground Response Spectrum for 10\% Damping) 
Attachment A: REDOX (Original "GT Strudl" Model) Input for Seismic Analysis

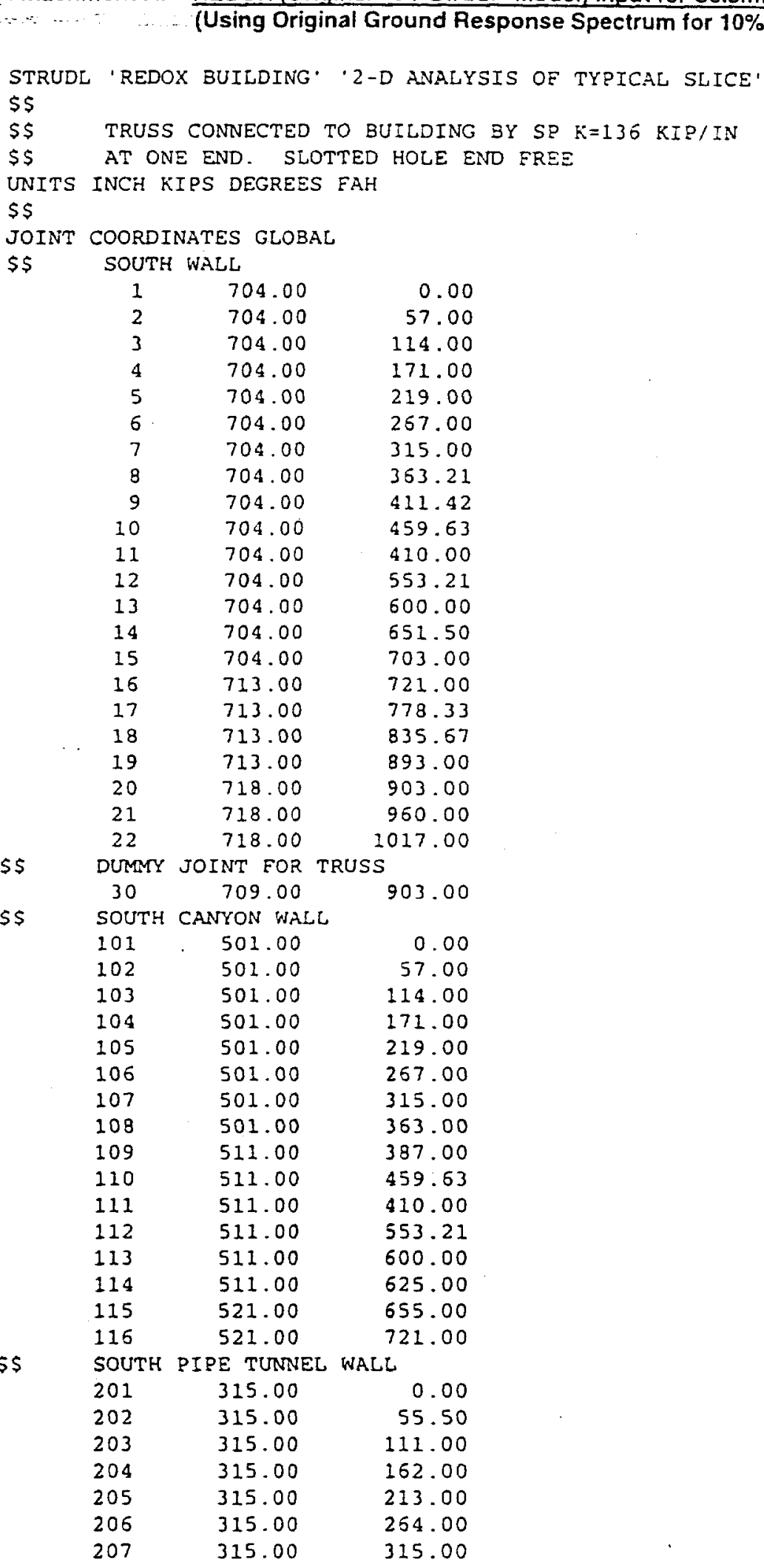


Attachment A: REDOX (Original "GT Strudl" Model) Input for Seismic Analysis (Using Original Ground Response Spectrum for 10\% Damping)

\begin{tabular}{|c|c|c|c|}
\hline \multirow[b]{2}{*}{$\$ \$$} & 208 & 267.00 & 363.00 \\
\hline & \multicolumn{3}{|c|}{ NORTH PIPE TUNNEL WALL } \\
\hline & 301 & 183.00 & 0.00 \\
\hline & 302 & 183.00 & 55.50 \\
\hline & 303 & 183.00 & 111.00 \\
\hline & 304 & 183.00 & 162.00 \\
\hline & 305 & 183.00 & 213.00 \\
\hline & 306 & 183.00 & 264.00 \\
\hline & 307 & 183.00 & 315.00 \\
\hline & 308 & 231.00 & 363.00 \\
\hline \multirow[t]{23}{*}{$\$ \$$} & \multicolumn{3}{|c|}{ NORTH CANYON WALL } \\
\hline & 401 & 0.00 & 0.00 \\
\hline & 402 & 0.00 & 57.00 \\
\hline & 403 & 0.00 & 114.00 \\
\hline & 404 & 0.00 & 171.00 \\
\hline & 405 & 0.00 & 219.00 \\
\hline & 406 & 0.00 & 267.00 \\
\hline & 407 & 0.00 & 315.00 \\
\hline & 408 & 0.00 & 363.00 \\
\hline & 409 & -28.00 & 403.00 \\
\hline & 410 & -28.00 & 459.00 \\
\hline & 411 & -28.00 & 513.75 \\
\hline & 412 & -28.00 & 568.50 \\
\hline & 413 & -28.00 & 623.25 \\
\hline & 414 & -28.00 & 678.00 \\
\hline & 415 & -28.00 & 703.00 \\
\hline & 416 & -37.00 & 721.00 \\
\hline & 417 & -37.00 & 778.00 \\
\hline & 418 & -37.00 & 835.67 \\
\hline & 419 & -37.00 & 893.00 \\
\hline & 420 & -42.00 & 903.00 \\
\hline & 421 & -42.00 & 960.00 \\
\hline & 422 & -42.00 & 1017.00 \\
\hline \multirow[t]{2}{*}{$\$ \$$} & DUnary & - JOINT FOR T & TRUSS CONNECTION \\
\hline & 430 & -33.00 & 903.00 \\
\hline \multirow[t]{14}{*}{$\$ 5$} & NORTH GALLERY WALL & \multicolumn{2}{|c|}{ GALLERY WALL } \\
\hline & 502 & -274.00 & 57.25 \\
\hline & 503 & -274.00 & 114.13 \\
\hline & 504 & -274.00 & 171.00 \\
\hline & 505 & -274.00 & 219.00 \\
\hline & 506 & -274.00 & 267.00 \\
\hline & 507 & -274.00 & 315.00 \\
\hline & 508 & -274.00 & 363.00 \\
\hline & 509 & -274.00 & 411.00 \\
\hline & 510 & -274.00 & 459.00 \\
\hline & 511 & -274.00 & 513.75 \\
\hline & 512 & -274.00 & 568.50 \\
\hline & 513 & -274.00 & 623.25 \\
\hline & 514 & -274.00 & 678.00 \\
\hline \multirow[t]{3}{*}{$\$ \$$} & SLAB & \multicolumn{2}{|c|}{1 a SOUTH GALLERY } \\
\hline & ' $51-1 \cdot$ & 568.67 & 171.00 \\
\hline & $51-2$ & 636.33 & 171.00 \\
\hline \multirow[t]{3}{*}{$5 \$$} & SLAB & S2 \& SOUTH & GALLERY \\
\hline & ' $52-1$ ' & 568.67 & 315.00 \\
\hline & & 636.33 & 315.00 \\
\hline$\$ \$$ & SLAB & S3 \& SOUTH & GALLERY \\
\hline & & 568.67 & 459.63 \\
\hline
\end{tabular}


BHI-01299

Rev. 0

Attachment A: REDOX (Original "GT Strudl" Model) Input for Seismic Analysis

(Using Original Ground Response Spectrum for 10\% Damping)

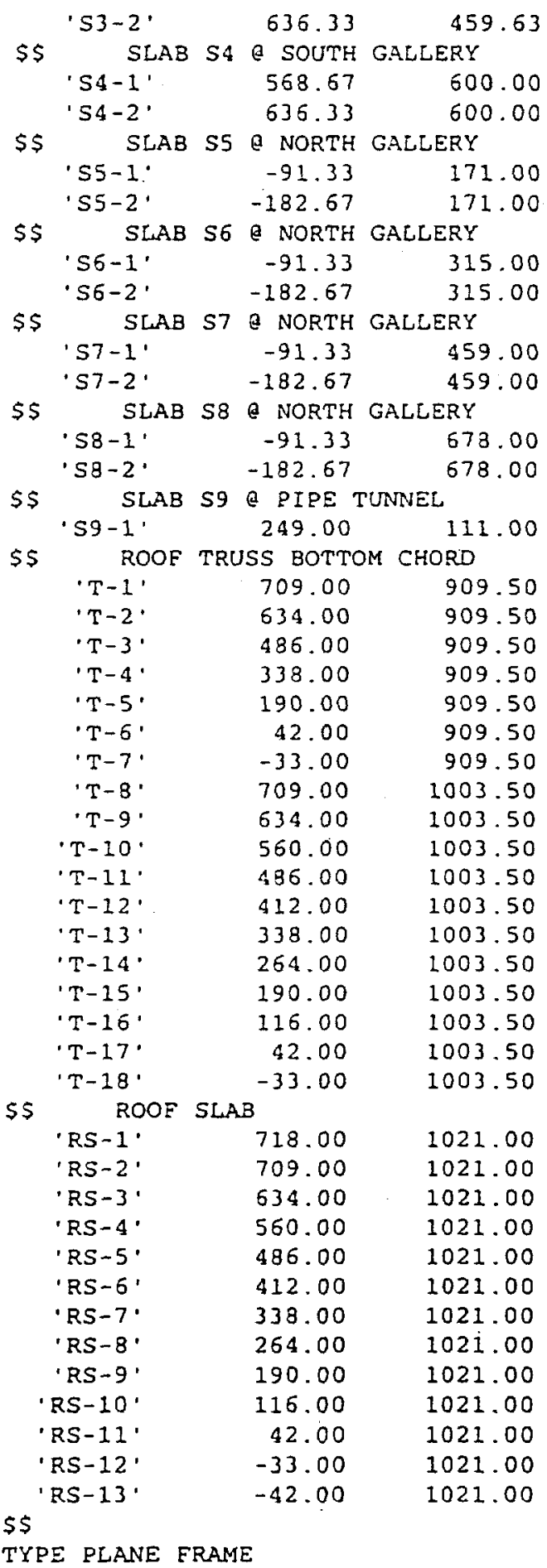

\$\$ MEMBER FOR SOUTH GALLERY WALL MEMBER INCIDENCES

$$
121
$$

GENERATE 20 MEMBERS ID 2 EROM 2 INC 1 TO 3 INC 1 


\section{Attachment A: REDOX (Original "GT Strudl" Model) Input for Seismic Analysis} (Using Original Ground Response Spectrum for 10\% Damping)

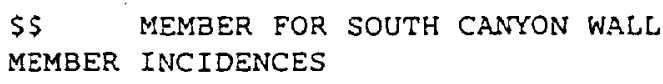

Sheet A5 of A10

ATTTACHMENT-A: Calc. No. 0200W-CA-C0156 Rev. No. 0 Job No. 22192 
BHI-01299

Rev. 0

Attachment A: REDOX (Original "GT Strudl" Model) Input for Seismic Analysis -(Using Original Ground Response Spectrum for 10\% Damping)

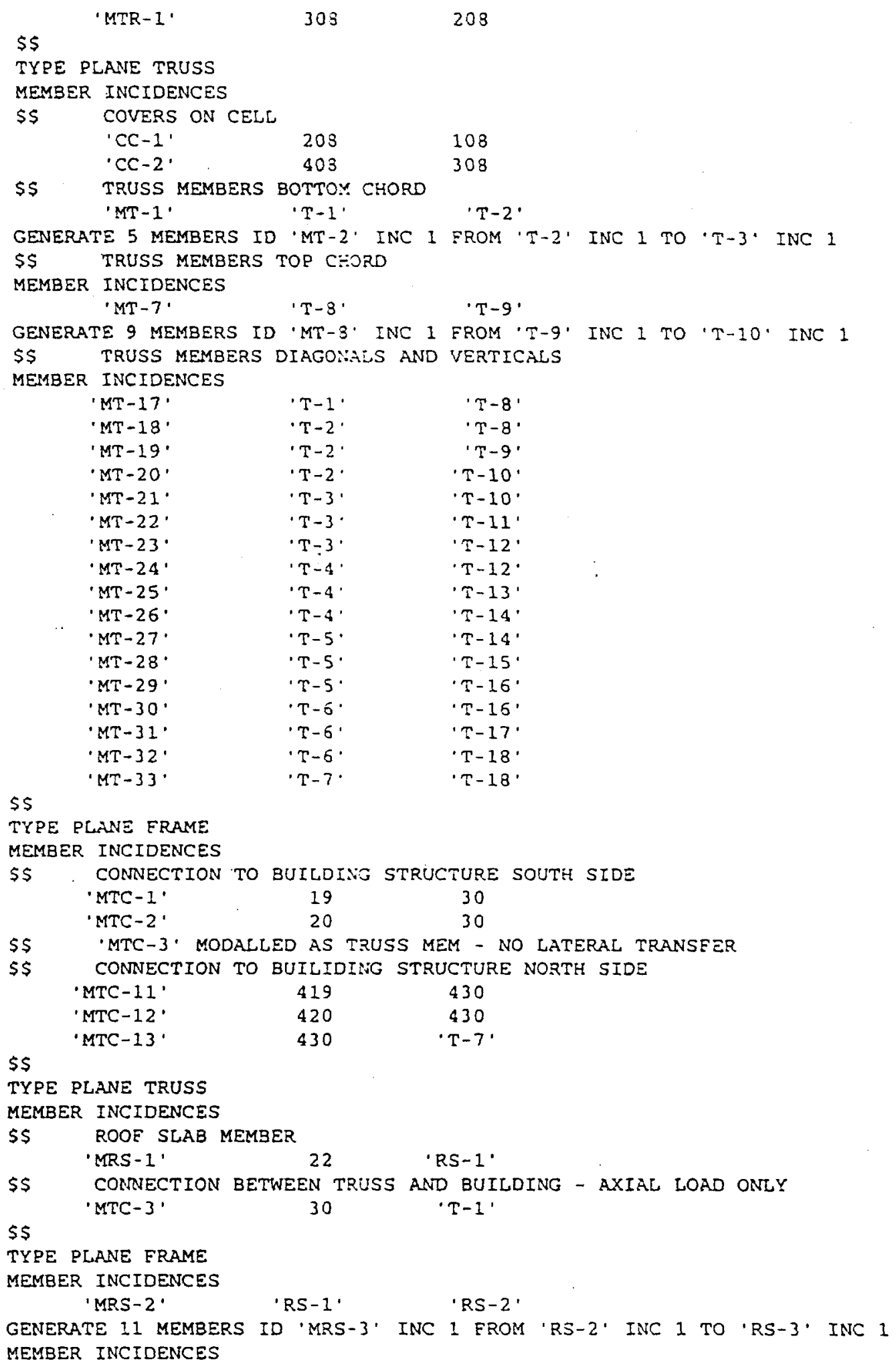


BHI-01299

Rev. 0

Attachment A: REDOX (Oriqinal "GT Strudl" Model) Input for Seismic Analysis (Using Original Ground Response Spectrum for 10\% Damping)

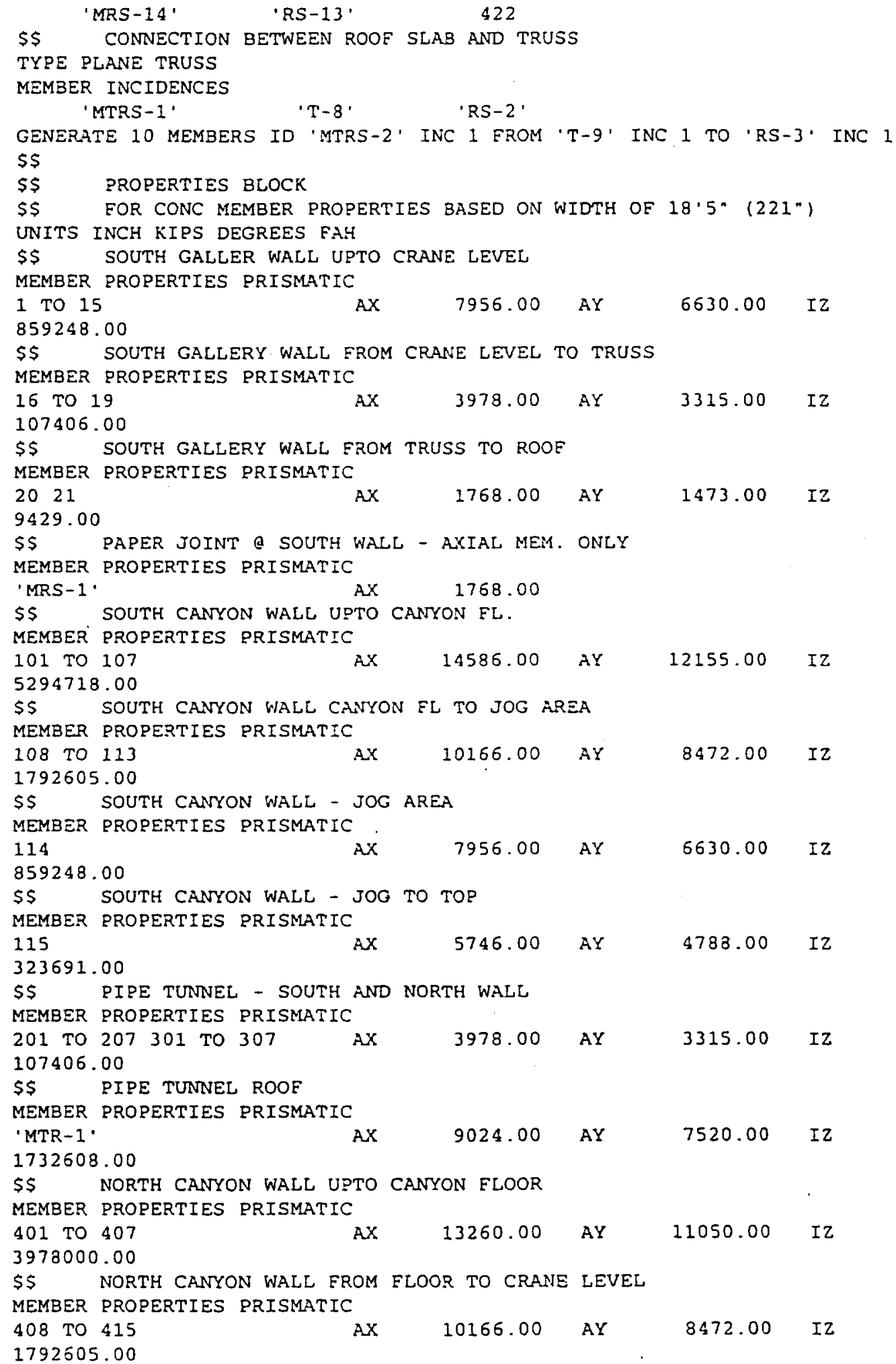


Attachment A: REDOX (Original "GT Strudl" Model) Input for Seismic Analysis (Using Original Ground Response Spectrum for $10 \%$ Damping)

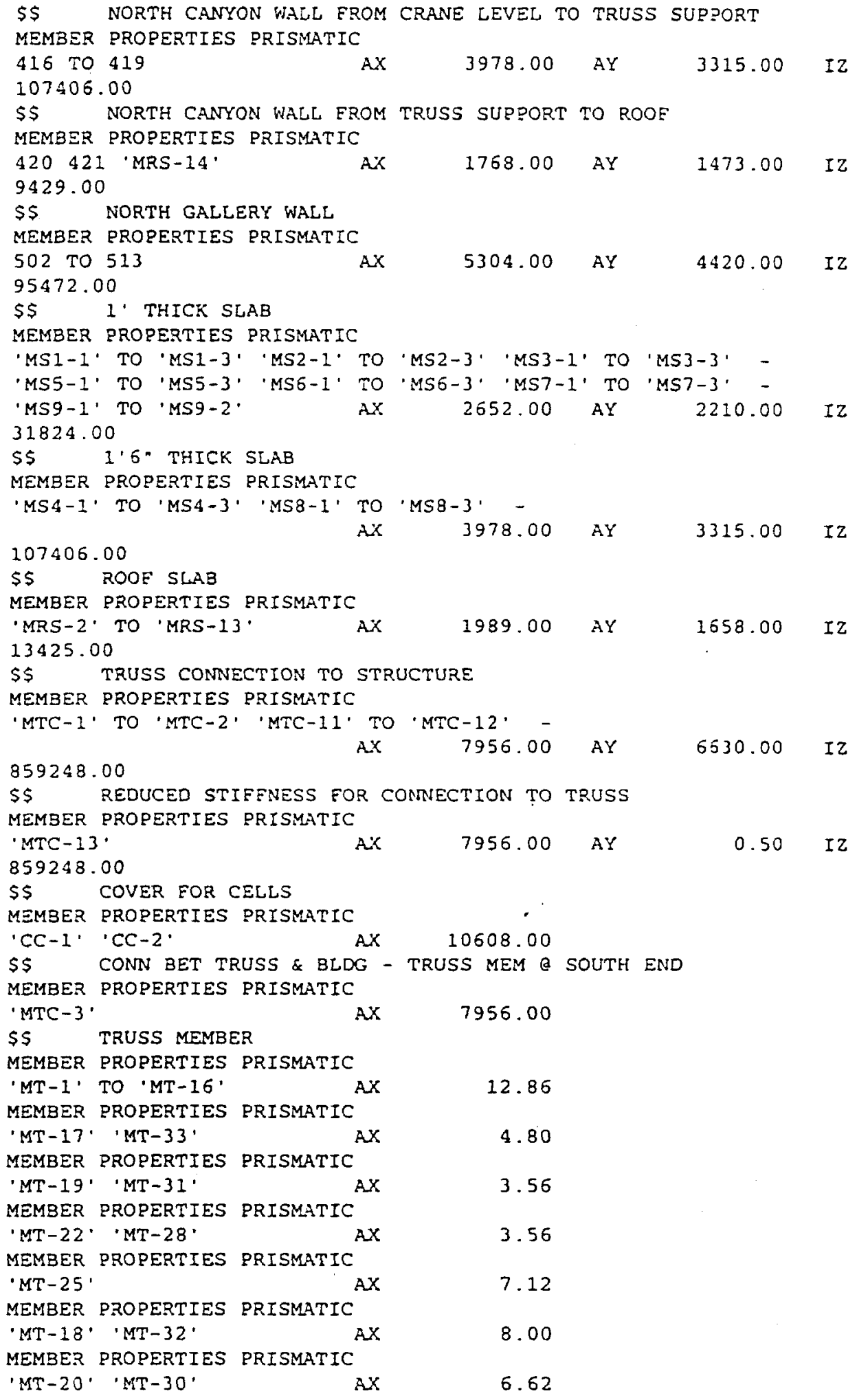




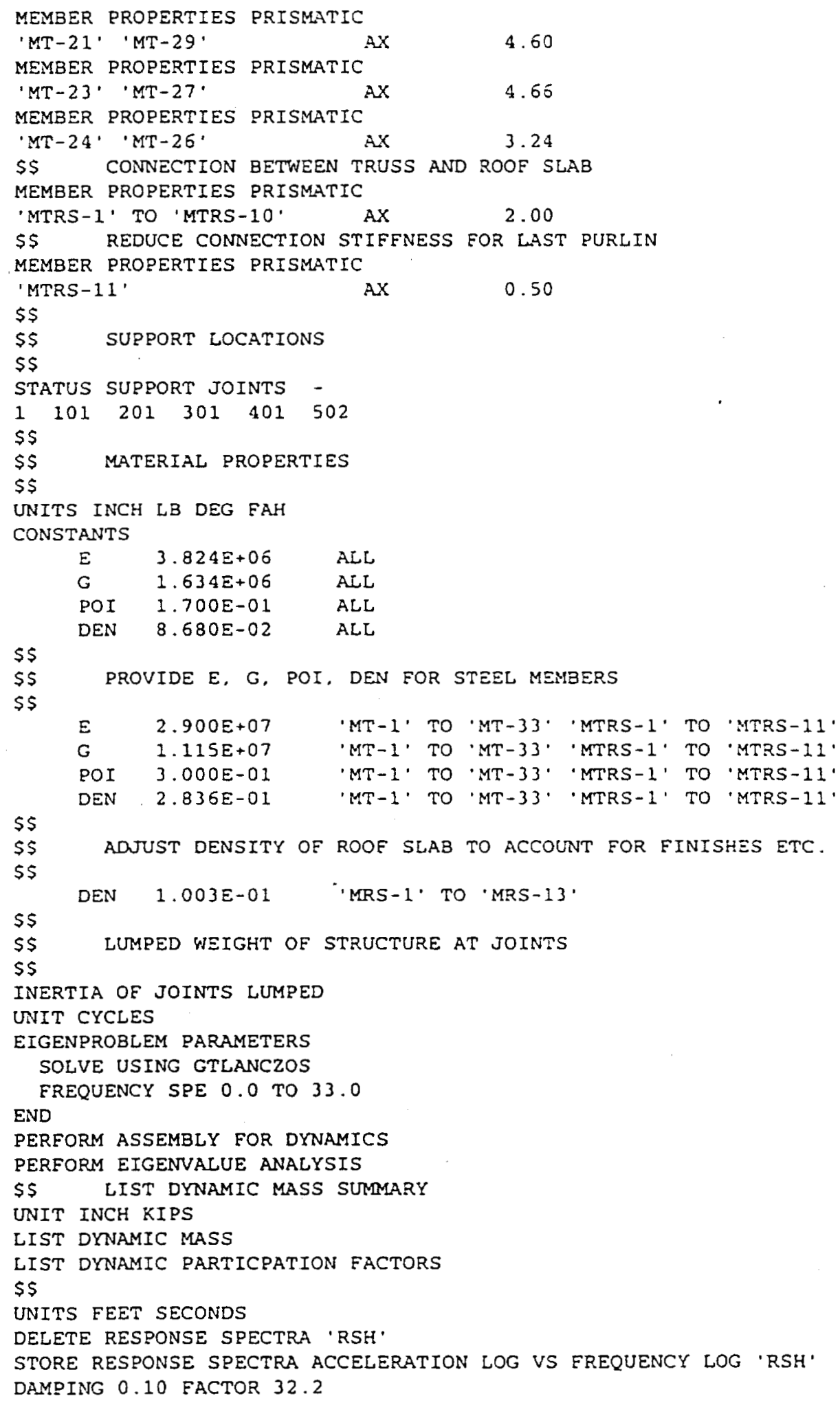

ATTTACHMENT-A: Calc. No. 0200 W-CA-C0156 Rev. No. 0 Job No. 22192 
BHI-01 299

Rev. 0

Attachment A: REDOX (Original "GT Strudl" Model) Input for Seismic Analysis

(Using Original Ground Response Spectrum for 10\% Damping)

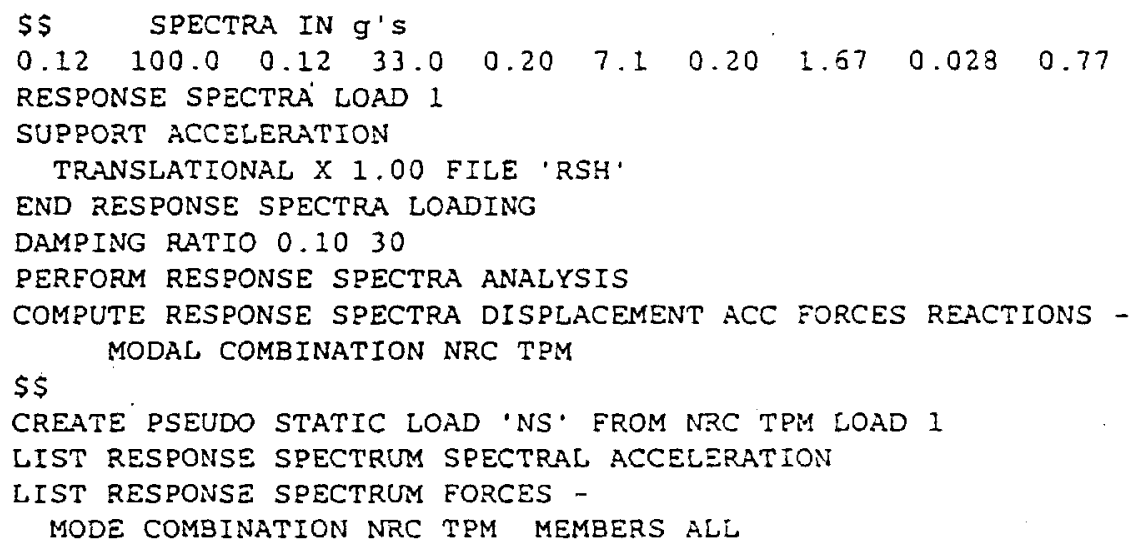


BHI-01299

Rev. 0

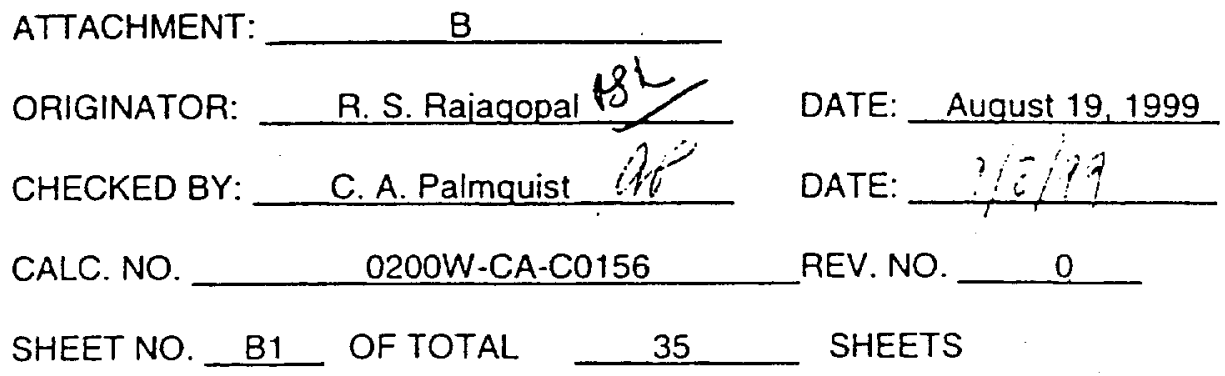

\section{ATTACHMENT "B"}

REDOX (Original "GT Strudl" Model) Output for Seismic Analysis (Using Original Ground Response Spectrum for 10\% Damping)

The governing output values used on sheet 13 are highlighted as " $\longleftarrow$ " in the following output. 
Attachment B: REDOX (Original "GT Strudl" Model) Output for Seismic Analysis

Rev. 0 (Using Original Ground Response Spectrum for 10\% Damping)

\author{
Commercial Software Rights Legend
}
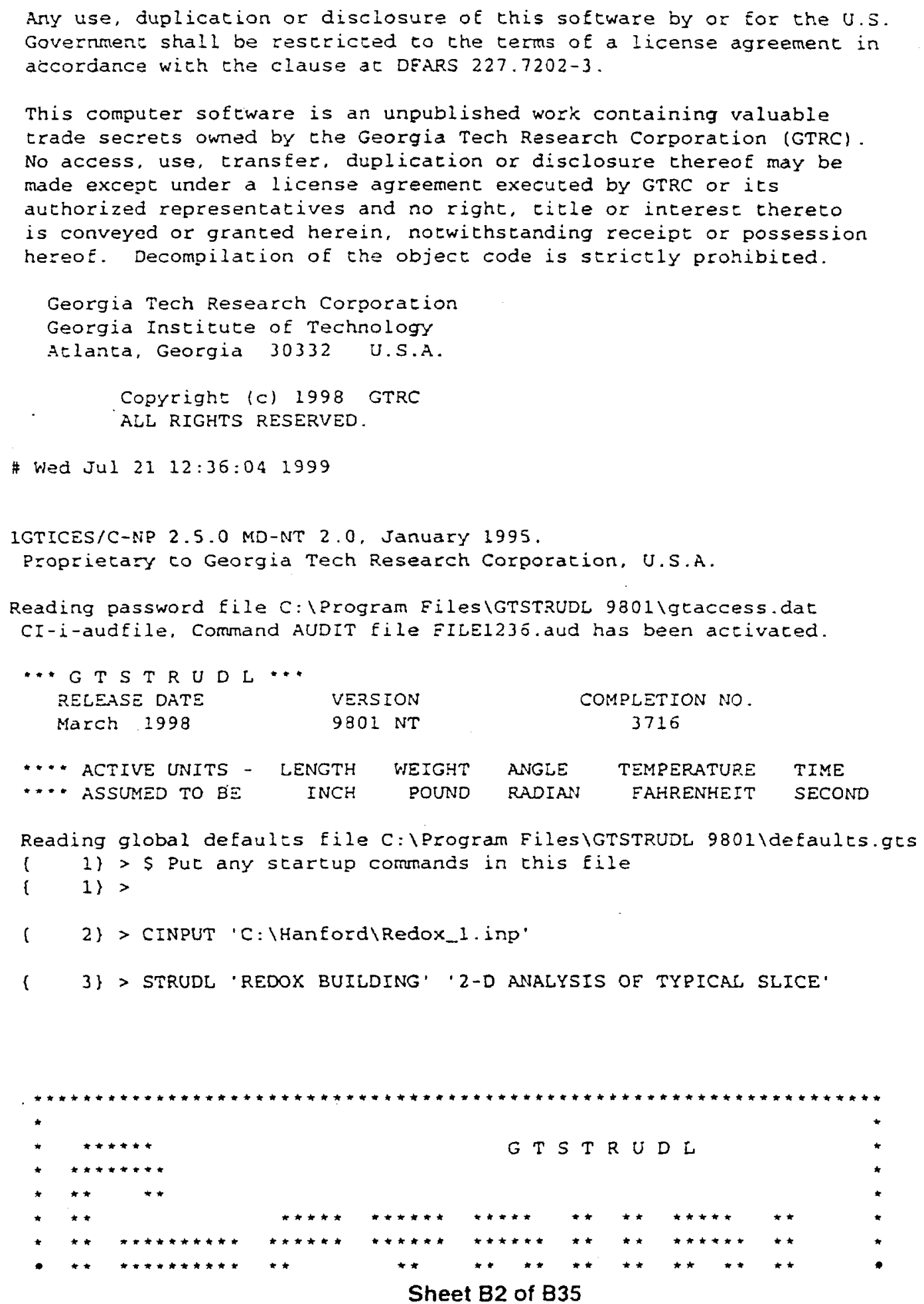

ATTTACHMENT-B: Calc. No. 0200W-CA-C0156 Rev. No. 0 Job No. 22192 
Attachment B: REDOX (Original "GT Strudl" Model) Output for Seismic Analysis (Using Original Ground Response Spectrum for 10\% Damping)

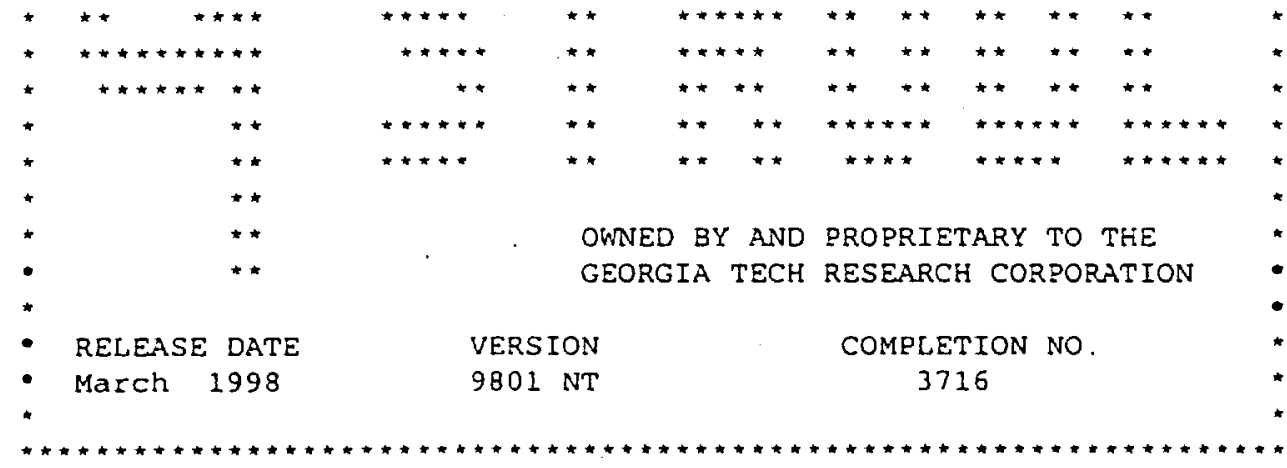

\begin{tabular}{|c|c|c|c|c|c|c|}
\hline * & STIVE US & GTH & WEIGHT & ANGLE & TEMPERATURE & TIME \\
\hline 1 & ASSUMED TO BE & INCH & POUND & RADIAN & FAHRENHEIT & SECOND \\
\hline
\end{tabular}

Reading global defaules file C:lProgram Files GGTSTRUDL 9801 1 defaults.gts (4) $>\$$ put any startup commands in this Eile

$(4)>$

$(5)>\$ \$$

$(6)>\$ \$$

$(7)>\$ \$$

( 8) > UNITS INCH KIPS DEGREES FAH

( 9$)>\$ \$$

( 10) > JOINT COORDINATES GLOBAL

( 11) $>\$ \$$ SOUTH WALL

$\begin{array}{llll}(12)> & 1 & 704.00 & 0.00\end{array}$

$\begin{array}{llll}(13)> & 2 & 704.00 & 57.00\end{array}$

( 14$\}>33704.00 \quad 114.00$

$\begin{array}{lllll}(15)> & 4 & 704.00 & 171.00\end{array}$

$\begin{array}{lllll}(16)> & 5 & 704.00 & 219.00\end{array}$

$\begin{array}{llll}(17\}> & 6 & 704.00 & 267.00\end{array}$

$\left(\begin{array}{llll}(18)>704.00 & 315.00\end{array}\right.$

(. 19$)>\quad 8 \quad 704.00 \quad 363.21$

(20\}> $\quad 9 \quad 704.00 \quad 411.42$

$(21)>\quad 10 \quad 704.00 \quad 459.63$

( 22)> $11 \quad 704.00 \quad 410.00$

$(23)>\quad 12 \quad 704.00 \quad 553.21$

$(24)>\quad 13 \quad 704.00 \quad 600.00$

$\left\{\begin{array}{llll}25\}> & 14 & 704.00 & 651.50\end{array}\right.$

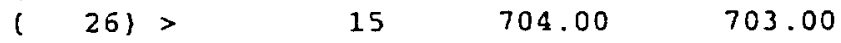

$\begin{array}{llll}(27\}> & 16 & 713.00 & 721.00\end{array}$

$(28)>\quad 17 \quad 713.00 \quad 778.33$

$\begin{array}{lllll}(29)> & 18 & 713.00 & 835.67\end{array}$

$\left(\begin{array}{llll}(30)> & 19 & 713.00 & 893.00\end{array}\right.$

$(31)>\quad 20 \quad 718.00 \quad 903.00$

$\begin{array}{llll}\{32\}> & 21 & 718.00 & 960.00\end{array}$

$(33)>\quad 22 \quad 718.00 \quad 1017.00$

$\{34\}>\$ \$$ DUMMY JOINT FOR TRUSS

$\begin{array}{llccc}(35\}> & 30 & 709.00 & 903.00\end{array}$

$\begin{array}{llllll}(36) & >\$ \$ & \text { SOUTH CANYON WALE } & \\ (37\} & > & 101 & 501.00 & 0.00\end{array}$

$\begin{array}{rrr}\{37\}>\quad 101 & 501.00 & 0.00 \\ & \text { Sheet B3 of B35 }\end{array}$

ATTTACHMENT-B: Calc. No. 0200W-CA-C0156 Rev. No. 0 Job No. 22192 
BHI-01299

Rev. 0

Attachment B: REDOX (Original "GT Strudl" Model) Output for Seismic Analysis

(Using Original Ground Response Spectrum for 10\% Damping)

\begin{tabular}{|c|c|c|c|c|}
\hline 38) & $>$ & 102 & 501.00 & 57.00 \\
\hline 39$\}$ & $>$ & 103 & 501.00 & 114.00 \\
\hline 40$\}$ & $>$ & 104 & 501.00 & 171.00 \\
\hline \&1) & $>$ & 105 & 501.00 & 219.00 \\
\hline 42\} & $>$ & 106 & 501.00 & 267.00 \\
\hline 43$\}$ & $>$ & 107 & 501.00 & 315.00 \\
\hline 44) & $>$ & 108 & 501.00 & 363.00 \\
\hline 45$\}$ & $>$ & 109 & 511.00 & 387.00 \\
\hline 46$\}$ & $>$ & 110 & 511.00 & 459.63 \\
\hline 47\} & $>$ & 111 & 511.00 & 410.00 \\
\hline 48$\}$ & $>$ & 112 & 511.00 & 553.21 \\
\hline 49) & $>$ & 113 & 511.00 & 600.00 \\
\hline 50$\}$ & $>$ & 114 & 511.00 & 625.00 \\
\hline 51$\}$ & $>$ & 115 & 521.00 & 655.00 \\
\hline 52$)$ & $>$ & 116 & 521.00 & 721.00 \\
\hline 53$\}$ & $>\$ \$$ & SOUTH & PIPE TUNNEL & WALL \\
\hline 54$\}$ & $>$ & 201 & 315.00 & 0.00 \\
\hline 55$\}$ & $>$ & 202 & 315.00 & 55.50 \\
\hline 56$\}$ & $>$ & 203 & 315.00 & 111.00 \\
\hline 57) & $>$ & 204 & 315.00 & 162.00 \\
\hline 58$\}$ & $>$ & 205 & 315.00 & 213.00 \\
\hline 59$\}$ & $>$ & 205 & 315.00 & 264.00 \\
\hline 60$\}$ & $>$ & 207 & 315.00 & 315.00 \\
\hline 611 & $>$ & 208 & 267.00 & 363.00 \\
\hline 62$\}$ & $>\$ \$$ & NORTH & RIPE TUNNEL & WALL \\
\hline 631 & $>$ & 301 & 183.00 & 0.00 \\
\hline 64) & $>$ & 302 & 183.00 & 55.50 \\
\hline 65$\}$ & $>$ & 303 & 183.00 & 111.00 \\
\hline 661 & $>$ & 304 & 183.00 & 152.00 \\
\hline 671 & $>$ & 305 & 183.00 & 213.00 \\
\hline 581 & $>$ & 306 & 183.00 & 264.00 \\
\hline 69) & $>$ & 307 & 183.00 & 315.00 \\
\hline 70$\}$ & $>$ & 308 & 231.00 & 363.00 \\
\hline 711 & $>s \$$ & NORTH & CANION WALL & \\
\hline 72$)$ & $>$ & 401 & 0.00 & 0.00 \\
\hline 731 & $>$ & 402 & 0.00 & 57.00 \\
\hline 74$\}$ & $>$ & 403 & 0.00 & 114.00 \\
\hline 75$\}$ & $>$ & 404 & 0.00 & 171.00 \\
\hline 76$)$ & $>$ & 405 & 0.00 & 219.00 \\
\hline 77$\}$ & $>$ & 406 & 0.00 & 267.00 \\
\hline 78$\}$ & $>$ & 407 & 0.00 & 315.00 \\
\hline 79$\}$ & $>$ & 408 & 0.00 & 363.00 \\
\hline 80$\}$ & $>$ & 409 & -28.00 & 403.00 \\
\hline 81$\}$ & $>$ & 410 & -28.00 & 459.00 \\
\hline 82$\}$ & $>$ & 411 & -28.00 & $513: 75$ \\
\hline 83$\}$ & $>$ & 412 & -28.00 & 568.50 \\
\hline 84) & $>$ & 413 & -28.00 & 623.25 \\
\hline 85$\}$ & $>$ & 414 & -28.00 & 678.00 \\
\hline 86$\}$ & $>$ & 415 & -28.00 & 703.00 \\
\hline 87$\}$ & $>$ & 416 & -37.00 & 721.00 \\
\hline 88$\}$ & $>$ & 417 & -37.00 & 778.00 \\
\hline 89$\}$ & $>$ & 418 & -37.00 & 835.67 \\
\hline 90$\}$ & $>$ & 419 & -37.00 & 893.00 \\
\hline 91) & $>$ & 420 & -42.00 & 903.00 \\
\hline 92$\}$ & $>$ & 421 & -42.00 & 960.00 \\
\hline 93$\}$ & $>$ & 422 & -42.00 & 1017.00 \\
\hline 94$\}$ & $>\$ \$$ & DUMMY & OINT FOR & ISS CONNEC \\
\hline
\end{tabular}

Sheet $B 4$ of $B 35$

ATTTACHMENT-B: Calc. No. 0200W-CA-C0156 Rev. No. 0 Job No. 22192 


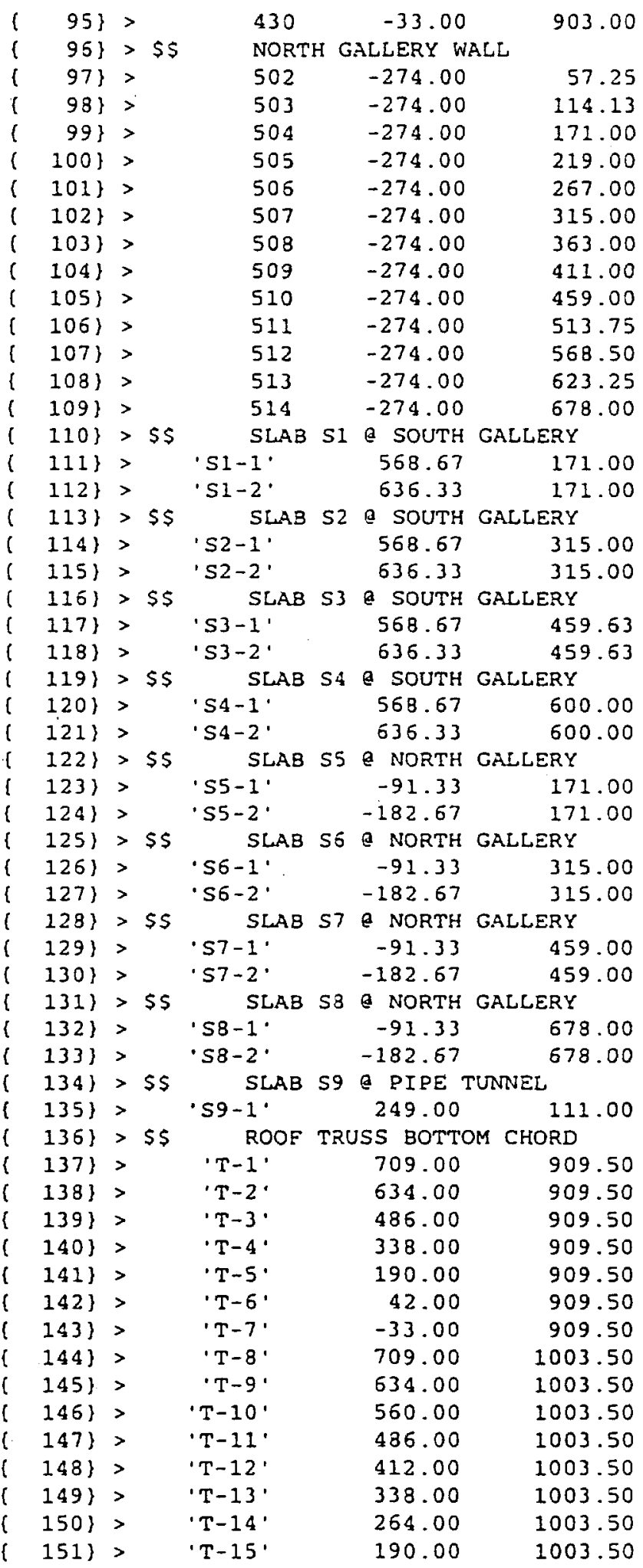


BHI-01299

Rev. 0

Attachment B: REDOX (Original "GT Strudl" Model) Output for Seismic Analysis (Using Original Ground Response Spectrum for 10\% Damping)

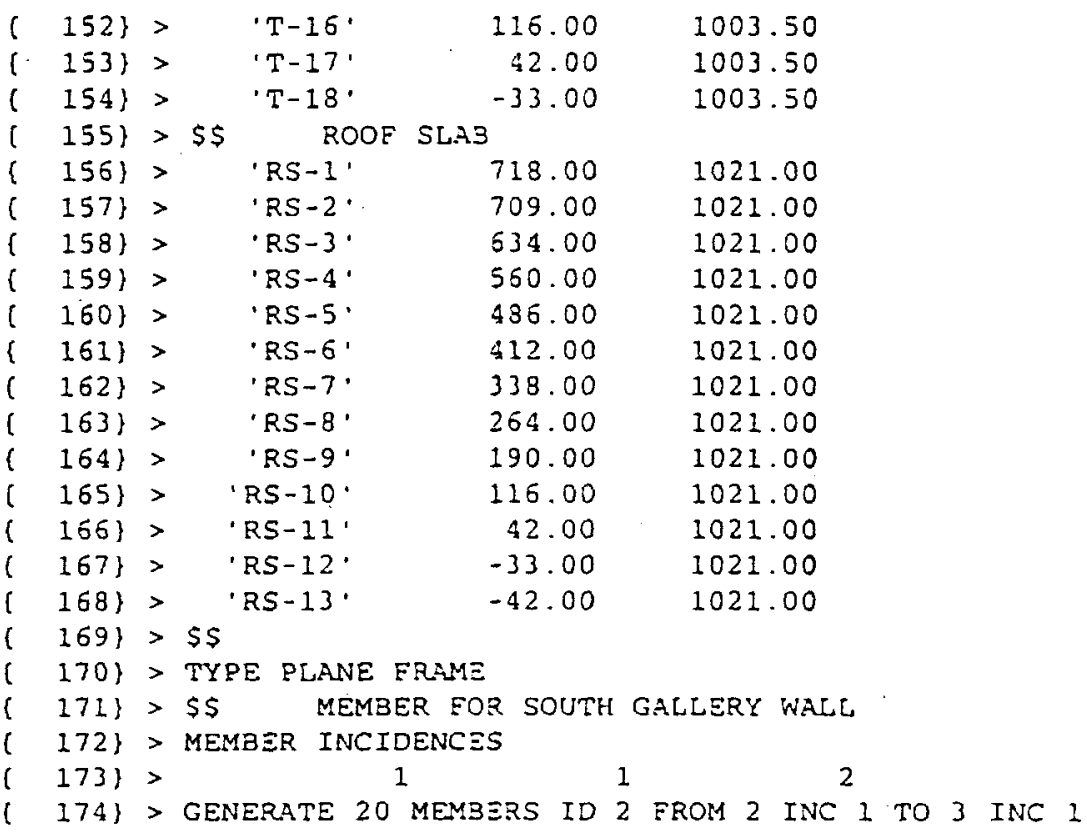

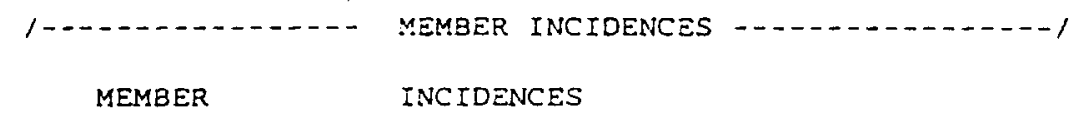

$\begin{array}{lll}2 & 2 & 3 \\ 3 & 3 & 4 \\ 4 & 4 & 5 \\ 5 & 5 & 6 \\ 5 & 6 & 7 \\ 7 & 7 & 8 \\ 8 & 8 & 9 \\ 9 & 9 & 10 \\ 10 & 10 & 11 \\ 11 & 11 & 12 \\ 12 & 12 & 13 \\ 13 & 13 & 14 \\ 14 & 14 & 15 \\ 15 & 15 & 16 \\ 16 & 16 & 17 \\ 17 & 17 & 18 \\ 18 & 18 & 19 \\ 19 & 19 & 20 \\ 20 & 20 & 21 \\ 21 & 21 & 22\end{array}$

( 175) > \$\$ MEMBER FOR SOUTH CANYON WALL

$\{176\}>$ MEMBER INCIDENCES

$\{177\}>101 \quad 101 \quad 102$

( 178 \} > GENERATE 14 MEMBERS ID 102 FROM 102 INC 1 TO 103 INC 1

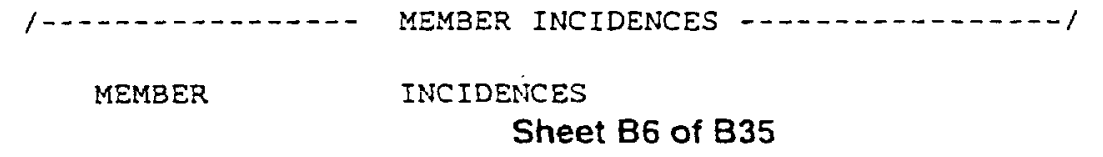

ATTTACHMENT-B: Calc. No. 0200W-CA-C0156 Rev. No. 0 Job No. 22192 
BHI-01 299

Rev. 0

Attachment B: REDOX (Original "GT Strudl" Model) Output for Seismic Analysis (Using Original Ground Response Spectrum for $10 \%$ Damping)

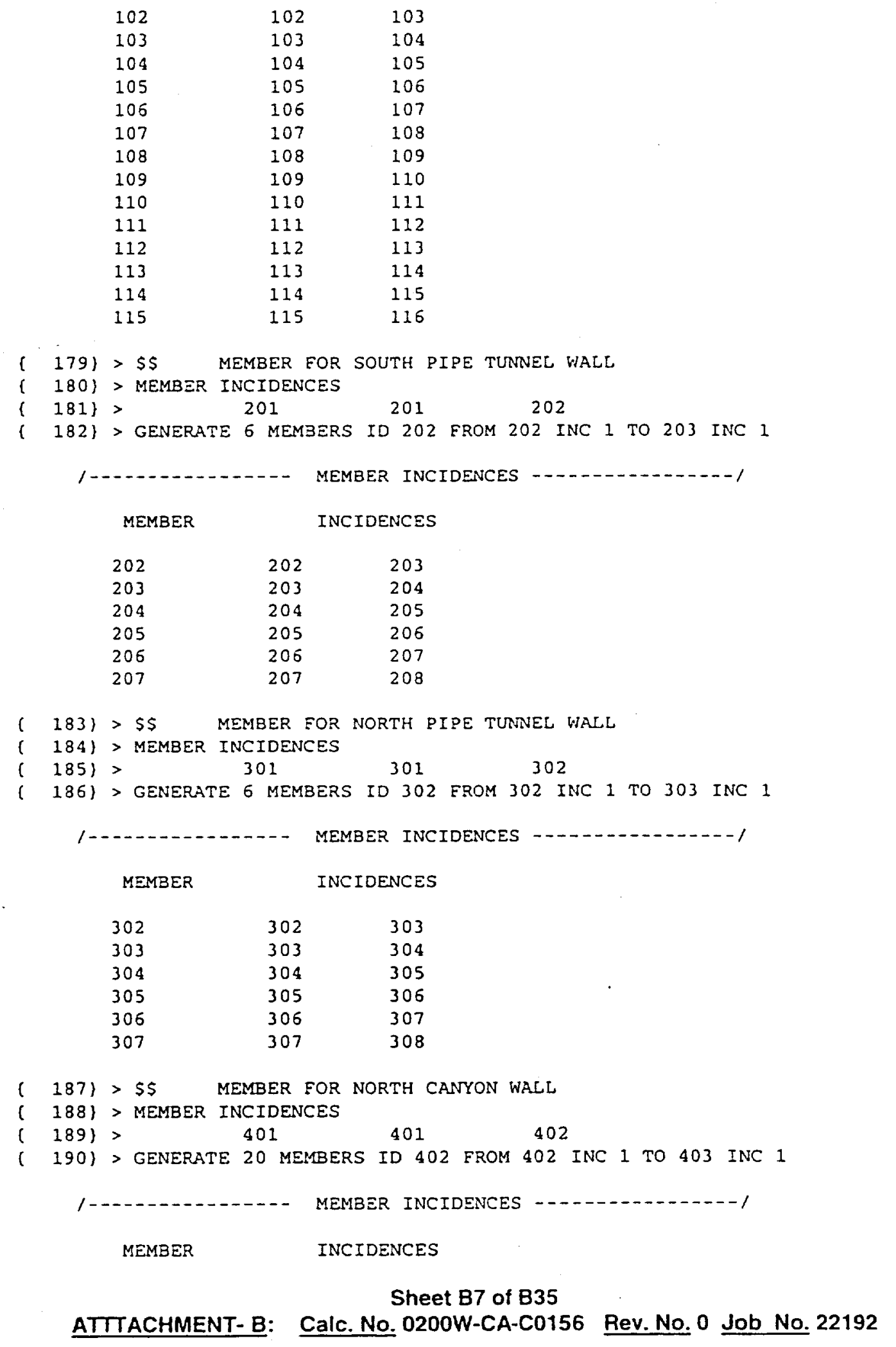


Attachment B: REDOX (Original "GT Strudl" Model) Output for Seismic Analysis

(Using Original Ground Response Spectrum for $10 \%$ Damping)

$\begin{array}{lll}402 & 402 & 403 \\ 403 & 403 & 404 \\ 404 & 404 & 405 \\ 405 & 405 & 406 \\ 406 & 406 & 407 \\ 407 & 407 & 408 \\ 408 & 408 & 409 \\ 409 & 409 & 410 \\ 410 & 410 & 411 \\ 411 & 411 & 412 \\ 412 & 412 & 413 \\ 413 & 413 & 414 \\ 414 & 414 & 415 \\ 415 & 415 & 416 \\ 416 & 416 & 417 \\ 417 & 417 & 418 \\ 418 & 418 & 419 \\ 419 & 419 & 420 \\ 420 & 420 & 421 \\ 421 & 421 & 422\end{array}$

( 191) > \$\$ MEMBER FOR NORTH GALLERY WALL

\{192\}> MEMBER INCIDENCES

$(193\}>502 \quad 502 \quad 503$

(194) > GENERATE 11 MEMBERS ID 503 FROM 503 INC 1 TO 504 INC 1

\begin{tabular}{lll} 
MEMBER & \multicolumn{2}{c}{ MEMBER INC } \\
& & \\
503 & 503 & 504 \\
504 & 504 & 505 \\
505 & 505 & 506 \\
506 & 506 & 507 \\
507 & 507 & 508 \\
508 & 508 & 509 \\
509 & 509 & 510 \\
510 & 510 & 511 \\
511 & 511 & 512 \\
512 & 512 & 513 \\
513 & 513 & 514
\end{tabular}

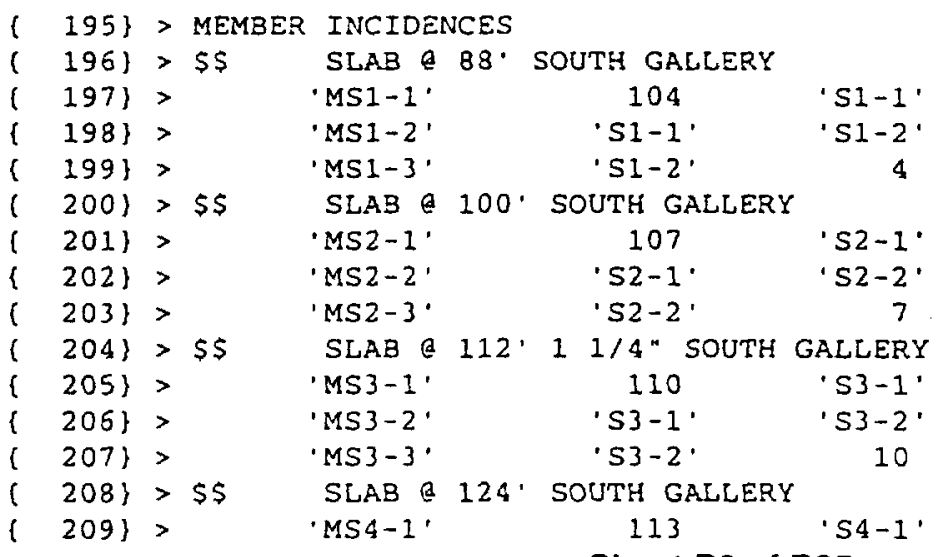

Sheet $\mathrm{B} 8$ of $\mathrm{B} 35$

ATTTACHMENT-B: Calc. No. 0200W-CA-C0156 Rev. No. 0 Job No. 22192 
BHI-01299

Rev. 0

Attachment B: REDOX (Original "GT Strudl". Model) Output for Seismic Analysis

= (Using Original Ground Response Spectrum for 10\% Damping)

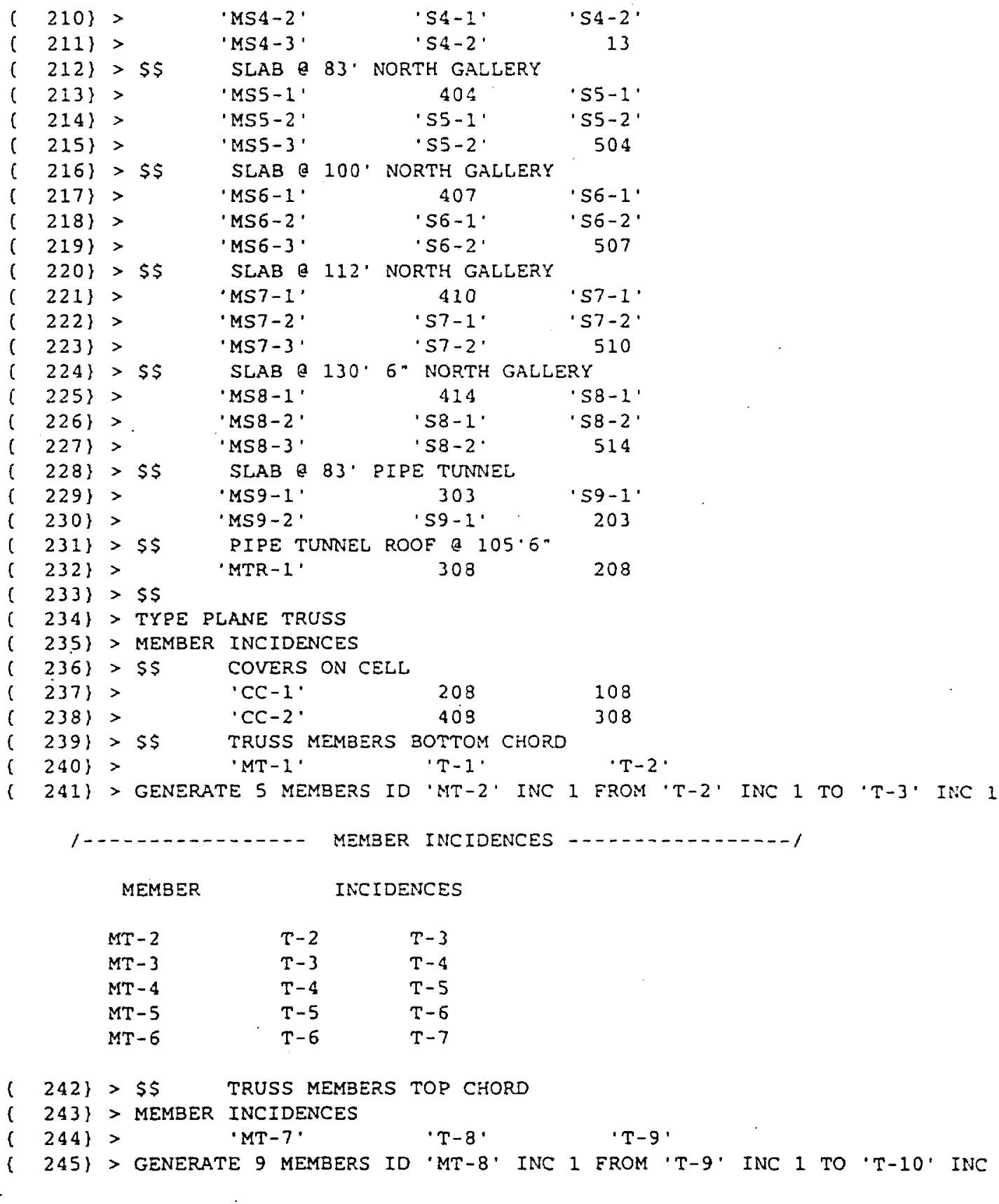

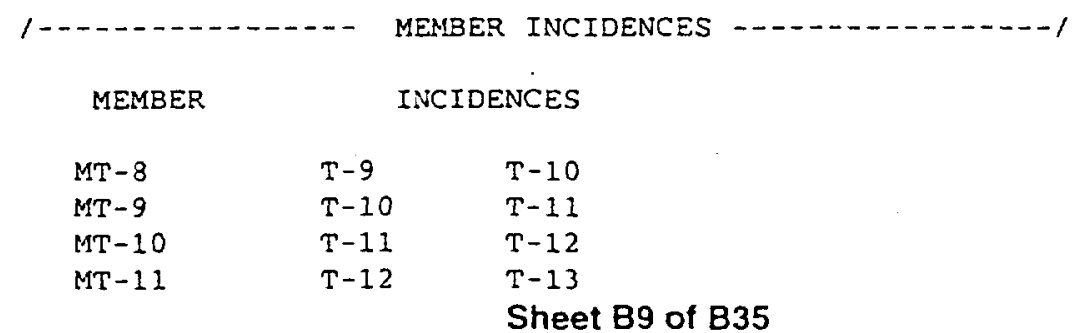

ATTTACHMENT-B: Calc. No. $0200 W-C A-C 0156$ Rev. No. 0 Job No. 22192 
BHI-01299

Rev. 0

Attachment B: REDOX (Original "GT Strudl" Model) Output for Seismic Analysis

(Using Original Ground Response Spectrum for $10 \%$ Damping)

$\begin{array}{lll}M T-12 & T-13 & T-14 \\ M T-13 & T-14 & T-15 \\ M T-14 & T-15 & T-16 \\ M T-15 & T-16 & T-17 \\ M T-16 & T-17 & T-18\end{array}$

( 246) $>\$ \$$ TRUSS MEMBERS DIAGONALS AND VERTICALS

(247\}> MEMBER INCIDENCES

( 248)> 'MT-17' 'T-1' 'T-8'

( 249$\}^{\prime}>\mathrm{MT}^{\prime}-18^{\circ} \mathrm{T}-2^{\prime} \mathrm{T}-\mathrm{C}^{\prime}$

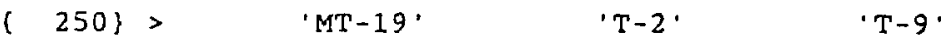

( 251$)>\quad \mathrm{MT}-20^{\prime} \quad \mathrm{C}^{\prime} \mathrm{T}-2^{\prime} \mathrm{T}-10^{\prime}$

$(252\}>\quad \mathrm{MT}-211^{\prime} \cdot \mathrm{T}-3^{\prime} \mathrm{T}-10^{\circ}$

$(253\}>\quad M T-22^{\circ} \quad T^{\prime}-3^{\prime}$ ' $\mathrm{T}-11^{\prime}$

( 254$)>\quad M T-23^{\prime} \quad T^{\prime} \mathrm{T}-3^{\circ} \mathrm{T}-12^{\prime}$

$(255)>\quad M T-24^{\circ} \quad T^{\circ}-4^{\prime} \cdot T-12$ '

$(256)>\quad M T-25^{\prime} \quad ' T-4^{\prime}$ ' $\mathrm{T}-13^{\prime}$

[. 257)> MT-26' 'T-4' 'T-14'

$\{258\}>\quad M T-27^{\circ} \quad T^{\prime} T-5^{\prime} \quad T^{\prime} T-14^{\prime}$

$(259)>\quad M T-28^{\prime} \quad$ T $>5^{\prime} \quad$ 'T $15^{\prime}$

$(260)>\quad M T-29^{\prime} \quad T-5^{\prime}$ 'T $-16^{\prime}$

$\{261\}>\quad \mathrm{MT}-30^{\circ} \quad \mathrm{T}-6^{\circ} \quad \mathrm{C}^{\circ} \mathrm{T}-16^{\prime}$

$(262)>\quad M T-31^{\prime} \quad \cdot T-\sigma^{\prime} \quad \cdot T-1 T^{\prime}$

$\{263\}>\quad M T-32^{\prime} \quad T-6^{\prime} \quad ' T-18$.

$\{264\}>\quad M T-33^{\prime} \quad T-7{ }^{\prime} T-18$.

$\begin{array}{ll}(265\} & > \\ (25 \\ (266)>\text { TYPE PLANE FRAME }\end{array}$

$(266)>$ TYPE PLANE FRAME
$\{267\}>$ MEMBER INCIDENCES

( 268) > \$S CONNECTION TO BUILDING STRUCTURE SOUTH SIDE.

$(269)>$ MTC-1' $19 \quad 30$

( 270)> MTC-2' $20 \quad 30$

( 271) > 55 'NTC-3' MODALLED AS TRUSS MEM - NO LATERAL TRANSFER

( 272$\}>$ S CONNECTION TO BUILIDING STRUCTURE NORTH SIDE

$(273)>$ MTC-11' $419 \quad 430$

$\{274\}>$ MTC-12' $\quad$ ' $420 \quad 430$

$\{275\}>\quad M T C-13^{\circ} \quad 430 \quad \cdot T-7 \cdot$

$(276)>5 \$$

( 277) > TYPE PLANE TRUSS

\{ 278\} > MEMBER INCIDENCES

( 279) $>5 \$$ ROOF SLAB MEMBER

( 280$\}>$ 'MRS-1' 22 'RS-1'

( 281$\}>\$ \$$ CONNECTION BETWEEN TRUSS AND BUILDING - AXIAL LOAD ONLY

$\{282\}>$ 'MTC-3' $30 \quad 0^{\prime} \mathrm{T}-1$ '

(283)>\$\$

(284) > TYPE PLANE FRAME

(. 285) > MEMBER INCIDENCES

$\{286\}>$ 'MRS-2' 'RS-1' 'RS-2'

( 287\} > GENERATE 1 I MEMBERS ID 'MRS-3' INC 1 FROM 'RS-2' INC 1 TO 'RS-3' INC 1

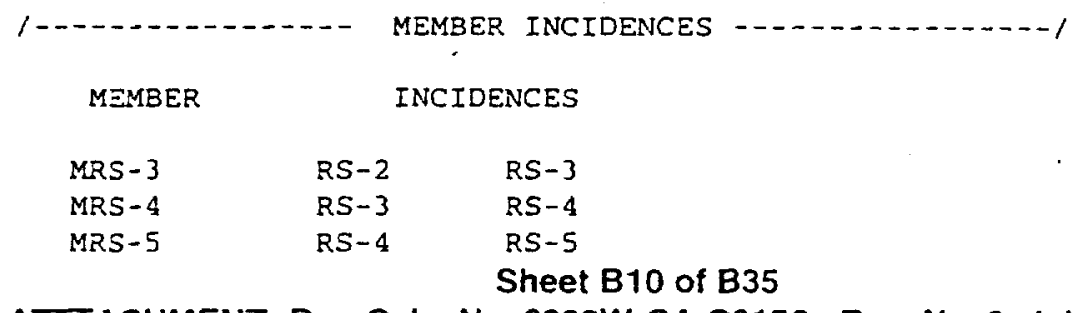

ATITACHMENT-B: Calc. No. 0200W-CA-C0156 Rev. No. 0 Job No. 22192 
Attachment B: REDOX (Original "GT Strudl" Model) Output for Seismic Analysis

(Using Original Ground Response Spectrum for 10\% Damping)

$\begin{array}{lll}\text { MRS }-6 & \text { RS }-5 & \text { RS-6 } \\ \text { MRS-7 } & \text { RS-6 } & \text { RS }-7 \\ \text { MRS-3 } & \text { RS-7 } & \text { RS-8 } \\ \text { MRS-9 } & \text { RS-8 } & \text { RS-9 } \\ \text { MRS-10 } & \text { RS-9 } & \text { RS-10 } \\ \text { MRS-11 } & \text { RS-10 } & \text { RS-11 } \\ \text { MRS-12 } & \text { RS-11 } & \text { RS-12 } \\ \text { MRS-13 } & \text { RS-12 } & \text { RS-13 }\end{array}$

(288) > MEMBER INCIDENCES

( 289$)^{\prime}>\quad$ 'MRS-14' $4^{\prime}$ 'RS-13' 422

$\{290\}>\$ \$$ CONNECTION BETWEEN ROOF SLAB AND TRUSS

( 291\} > TYPE PLANE TRUSS

(292) > MEMBER INCIDENCES

$\{293\}>$ 'MTRS-1' T T-8' 'RS-2'

( 294\} > GENERATE 10 MEMBERS ID 'MTRS-2' INC 1 FROM 'T-9' INC 1 TO 'RS-3. INC 1

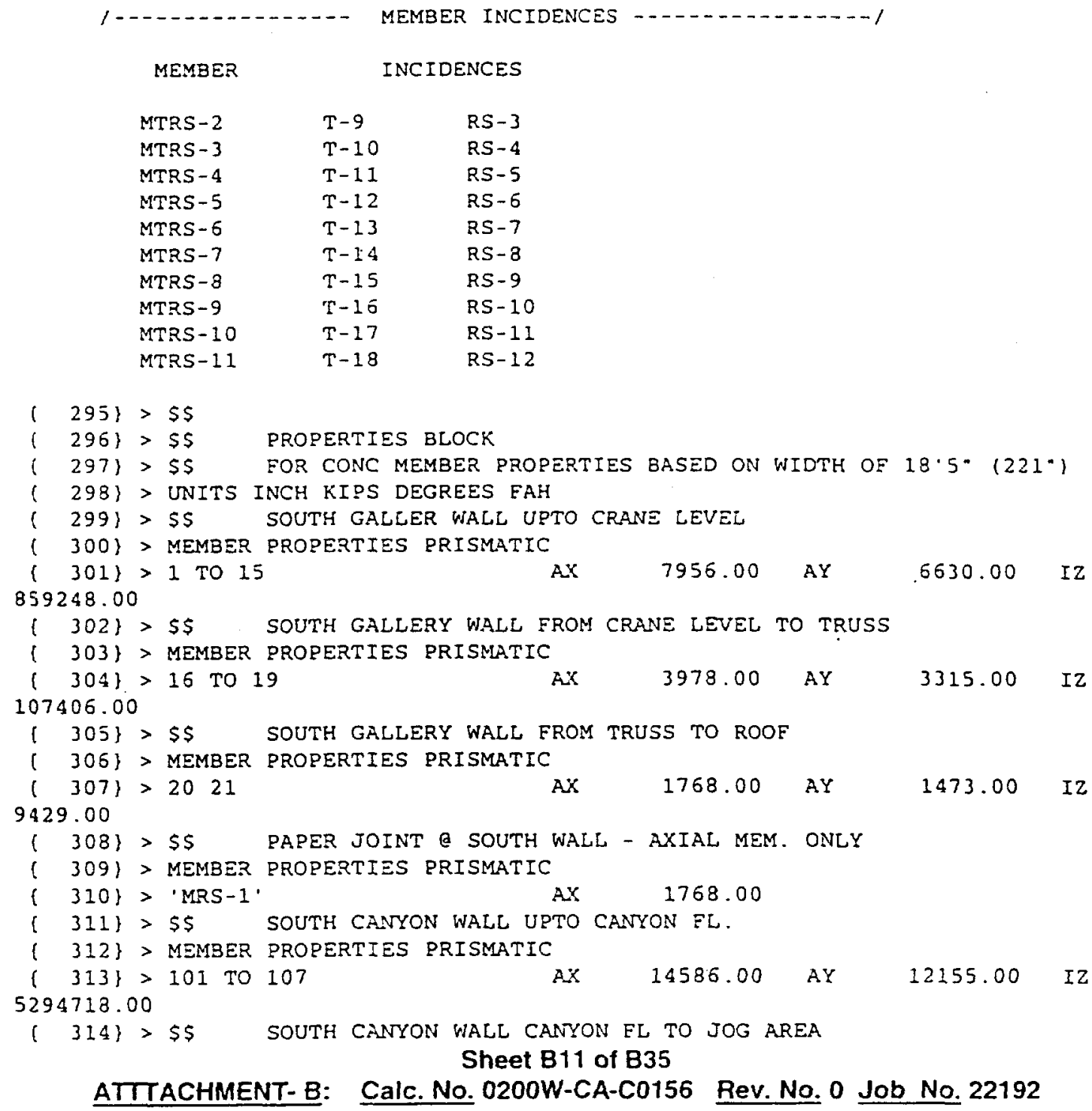

ATTTACHMENT-B: Calc. No. 0200 W-CA-C0156 Rev. No. 0 Job No. 22192 


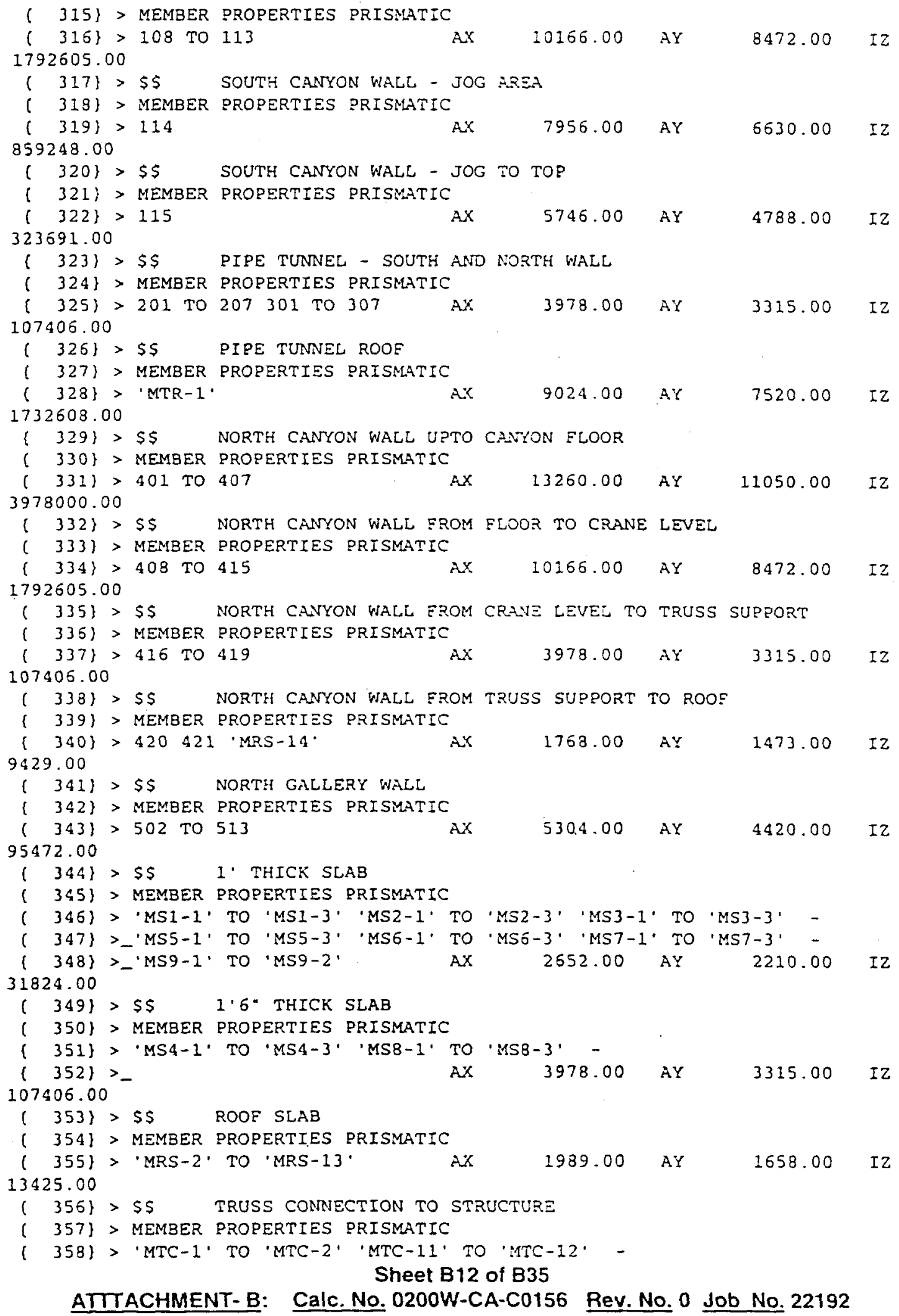


Attachment B: REDOX (Original "GT Strudl" Model) Output for Seismic Analysis (Using Original Ground Response Spectrum for 10\% Damping)

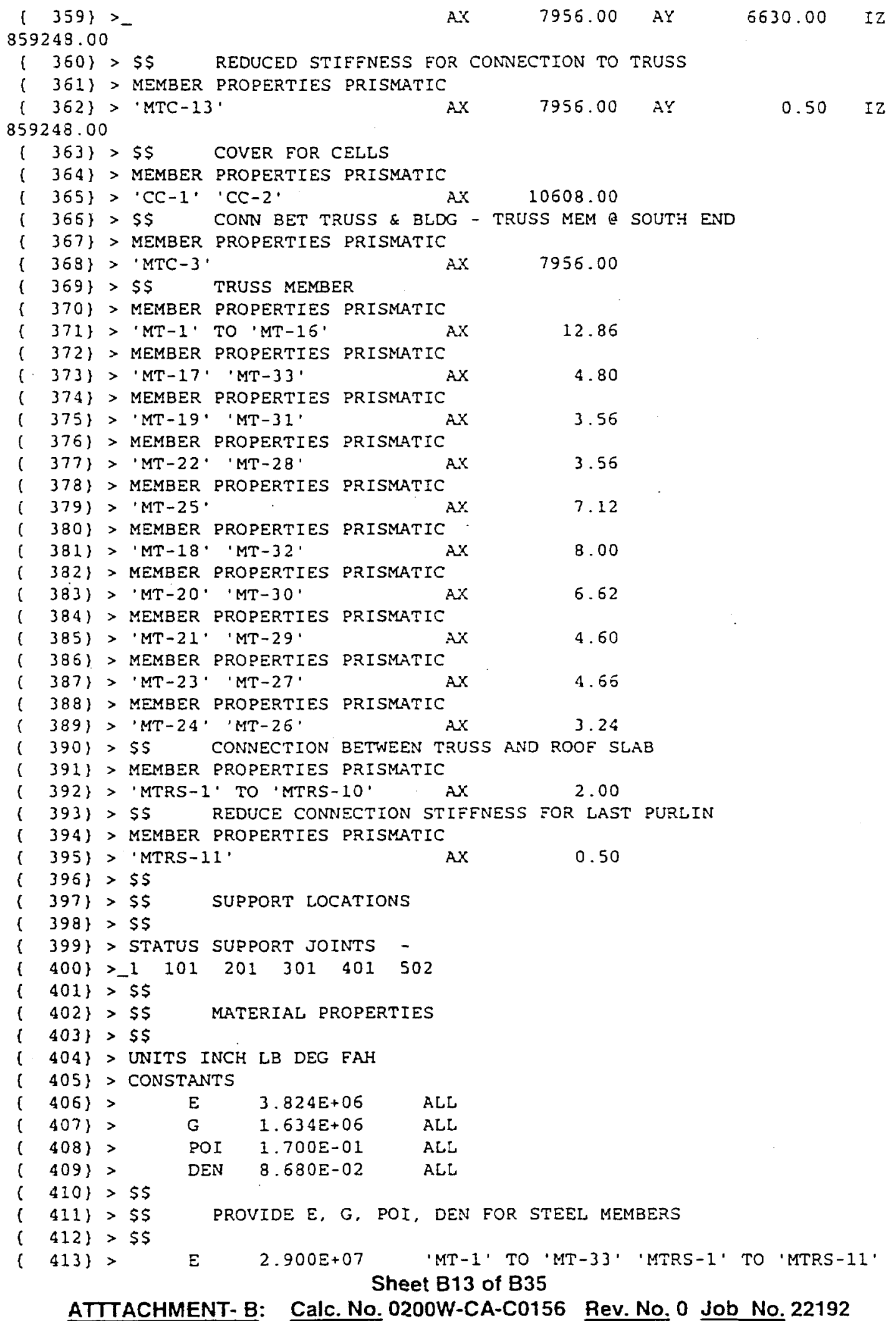

ATTTACHMENT-B: Calc. No. 0200W-CA-C0156 Rev. No. 0 Job No. 22192 
BHI-0I299

Rev. 0

Attachment B: REDOX (Original "GT Strudl" Model) Output for Seismic Analysis (Using Original Ground Response Spectrum for 10\% Damping)

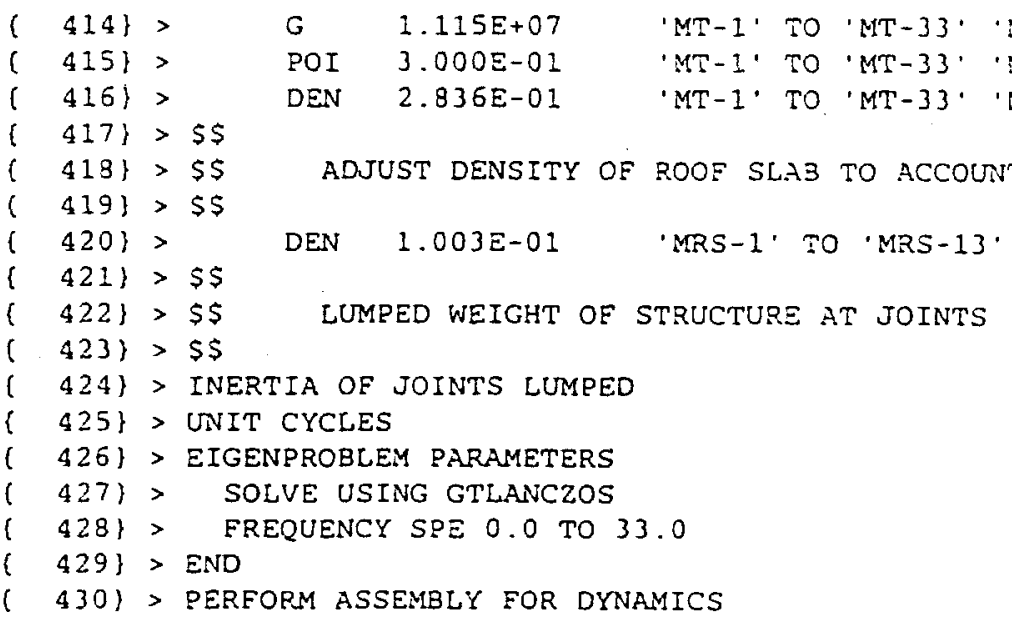

BANOWIDTH INEORMATION BEFORE RENUMBERING.

THE MAKIMUM BANOWIDTH IS 100 AND OCCURS AT JOINT RS-1 THE AVERAGE BANDWIDTH IS 11.165 THE STANDARD DEVIATION OE THE BANDWIDTH IS 21.338

32.503

$========$

BANDWIDTH INEORMATION AFTER RENUMBERING.

THE MAXIMUM BANDWIDTH IS THE AVERAGE BANDWIDTH IS

9 AND OCCURS AT JOINT $57-2$

THE STANDARD DEVIATION OF

5.511
OF THE BANDWIDTH IS 1.914$$
\text { 7. } 425
$$$$
====\pi====
$$
TIME FOR CONSISTENCY CHECK FOR
176 MEMBERS
0.00 SECONDS
TIME FOR BANOWIDTH REDUCTION
TIF. MATRICES
0.02 SECONDS
TIME TO GENERATE 176 ELEMENT STIF.
TIME TO PROCESS 139 JOINTS
TIME TO GENERATE REDUCED STIFFNESS MATRIX
TIME TO ASSEMBLE LUMPED MASS MATRIX
0.01 SECONDS
0.04 SECONDS
0.00 SECONDS
0.01 SECONDS
0.00 SECONDS

\{ 431 \} > PERFORM EIGENVALUE ANALYSIS

*** STRUDL MESSAGE DY.409 - THERE ARE 24 FREQUENCIES LESS THAN OR EQUAL TO THE SPECIEIED MAXIMUM EREQUENCY

TIME TO SOLVE EIGENPROBLEM

TIME TO TRANSFORM EIGENVECTORS TO JOINTS
0.39 SECONDS
0.02 SECONDS

\section{Sheet $\mathrm{B} 14$ of $\mathrm{B} 35$}

ATITACHMENT-B: Calc. No. 0200W-CA-C0156 Rev. No. 0 Job No. 22192 
Attachment B: REDOX (Original "GT Strudl" Model) Output for Seismic Analysis

(Using Original Ground Response Spectrum for 10\% Damping)

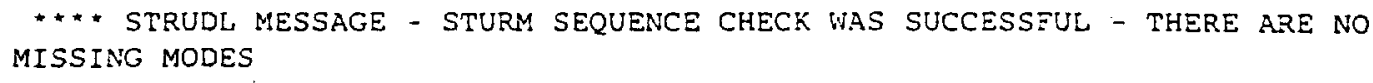

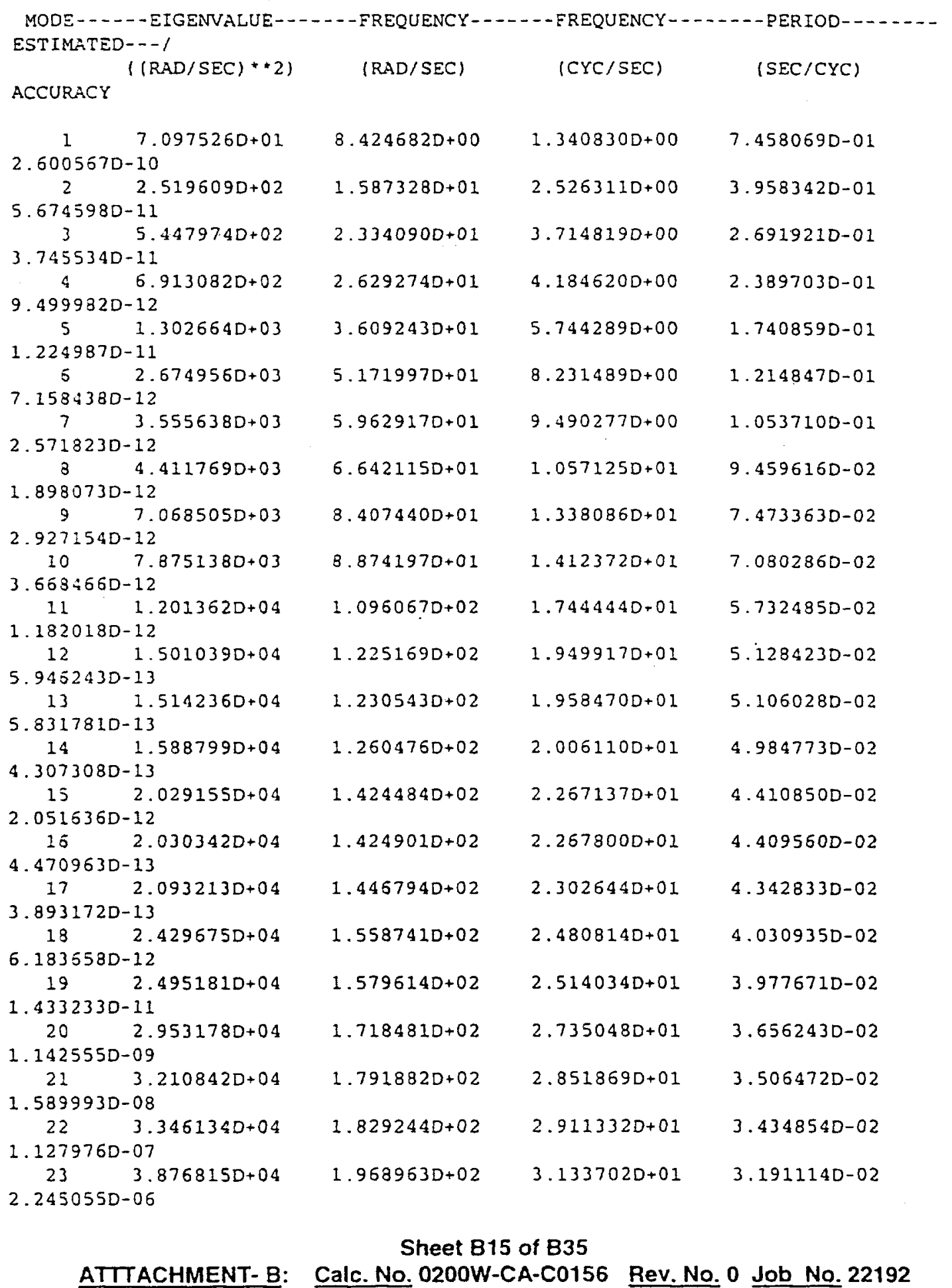


BHI-01299

Rev. 0

Attachment B: REDOX (Original "GT Strudl" Model) Output for Seismic Analysis

(Using Original Ground Response Spectrum for $10 \%$ Damping)
24
3. $9622190+04$
$1.990532 D+02$
$3.1680310+01$
$3.1565350-02$ $5.6391870-06$

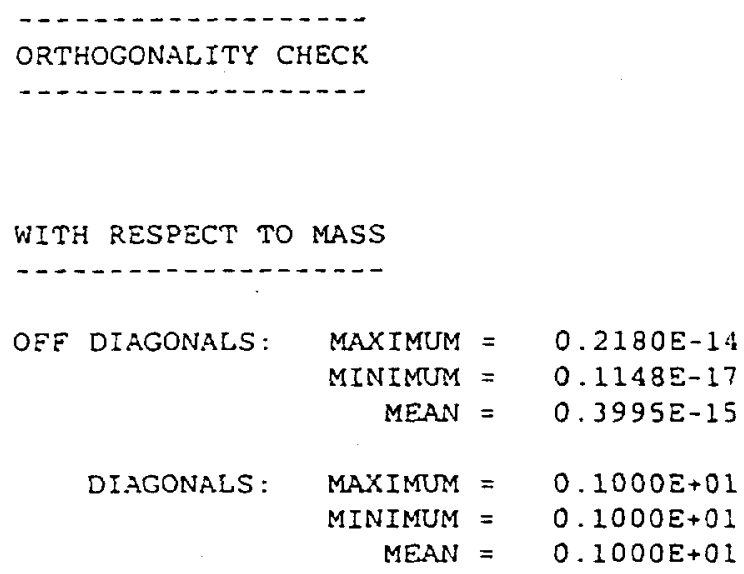

* END OF EIGEN-SOLUTION CHECKS *

$* * * * * * * * * * * * * * * * * * * * * \ldots * * * *$

TIME TO CHECK EIGENSOLUTION

( 432) > \$\$ LIST DYNAMIC MASS SUMMARY

0.11 SECONDS

\{433\}> UNIT INCH KIPS

(434)> LIST DYNAMIC MASS

1

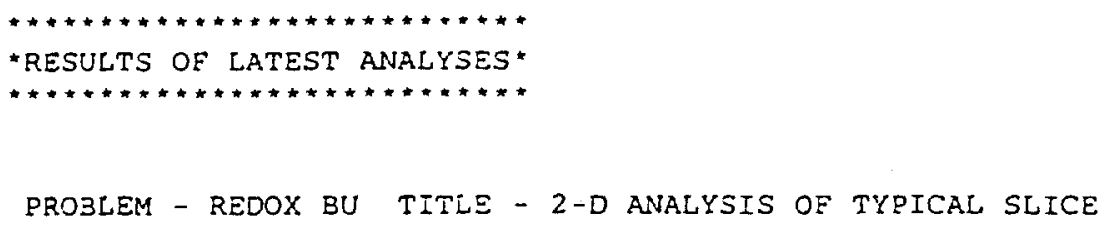

ATTTACHMENT-B: Calc. No. 0200W-CA-C0156 Rev. No. 0 Job No. 22192 
Attachment B: REDOX (Original "GT Strudl" Model) Output for Seismic Analysis

ACTIVE UNITS INCH KIP CYC DEGF SEC

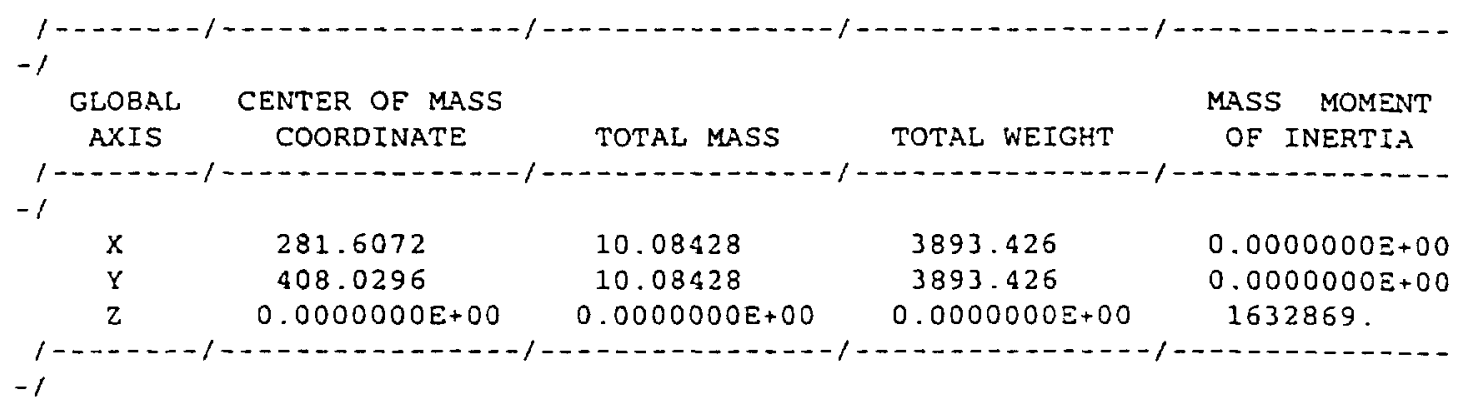

$\{435\}>$ LIST DYNAMIC PARTICPATION FACTORS

1

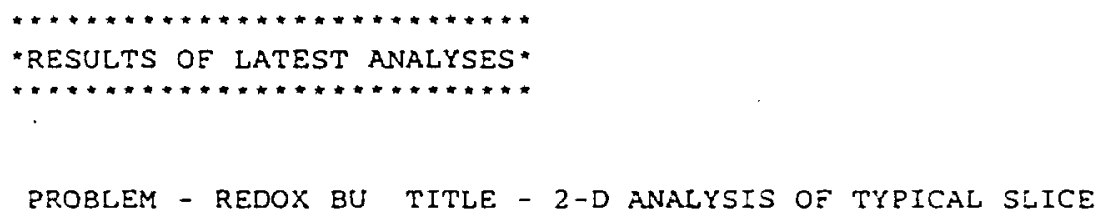

ACTIVE UNITS INCH KIP CYC DEGF SEC

NORMALIZED PARTICIPATION EACTORS

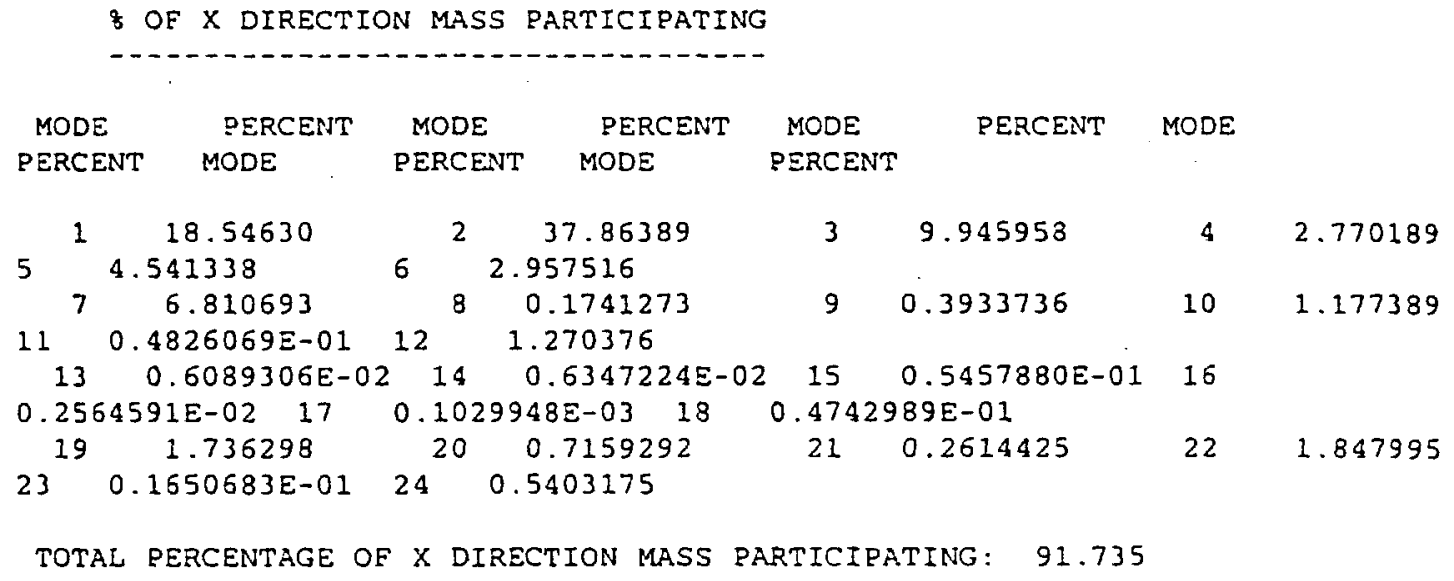

ATTTACHMENT-B: Calc. No. 0200W-CA-C0156 Rev. No. 0 Job No. 22192 
Attachment B: REDOX (Original "GT Strudl" Model) Output for Seismic Analysis (Using Original Ground Response Spectrum for 10\% Damping)

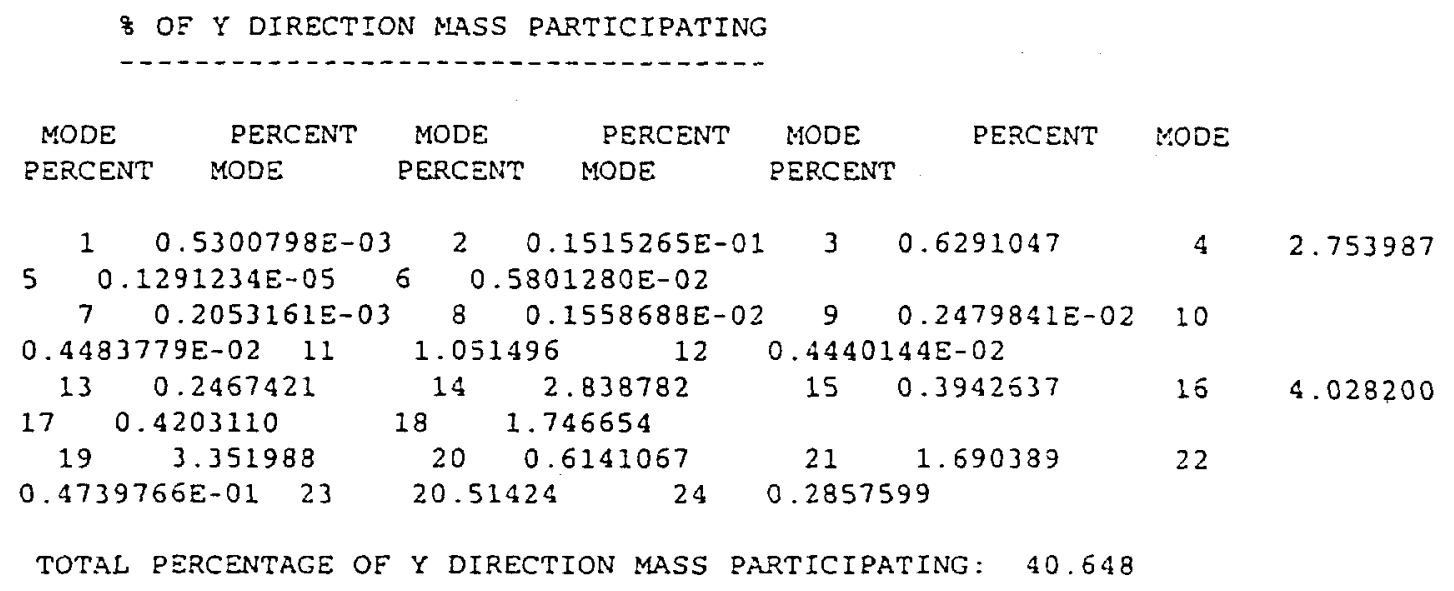

NO MASS IN $Z$ DIRECTION

$(436)>\$ 5$

(437) > UNITS EEET SECONDS

( 438$\}>$ DELETE RESPONSE SPECTRA 'RSH'

** STRUDL ERROR DY.81 - FILE RSH DOES NOT EXIST ON USER DATA SET

( 439 ) > STORE RESPONSE SPECTRA ACCELERATION LOG VS EREQUENCY LOG 'RSH'

( 440$)>$ DAMPING 0.10 EACTOR 32.2

(441)>5\$ SPECTRA IN g'S

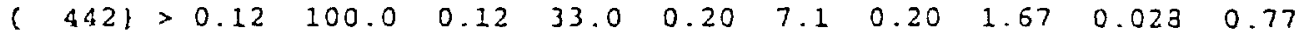

(443) > RESPONSE SPECTRA LOAD 1

$\{444\}>$ SUPPORT ACCELERATION

(445)> TRANSLATIONAL $X 1.00$ FILE 'RS\%'

( 446$\}>$ END RESPONSE SPECTRA LOADING

$\{447\}>$ DAMPING RATIO 0.1030

( 448) > PERFORM RESPONSE SPECTRA ANALYSIS

TIME TO COMPUTE RESPONSE SPECTRA RESULTS

0.00 SECONDS

$\{449\}>$ COMPUTE RESPONSE SPECTRA DISPLACEMENT ACC FORCES REACTIONS -

(450) > MODAL COMBINATION NRC TPM

TIME FOR RESPONSE SPECTRA COMPUTATION 0.45 SECONDS

(451)> $\$ \$$

$\{452\}>$ CREATE PSEUDO STATIC LOAD 'NS' FROM NRC TPM LOAD 1

( 453) > LIST RESPONSE SPECTRUM SPECTRAL ACCELERATION

1

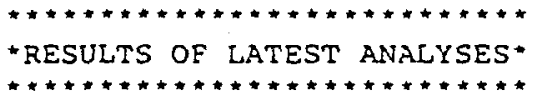

PROBLEM - REDOX BU TITLE - 2-D ANALYSIS OF TYPICAL SLICE

ACTIVE UNITS FEET KIP CYC DEGF SEC

ATTTACHMENT-B: Calc. No. 0200W-CA-C0156 Rev. No. 0 Job No. 22192 
BHI-01299

Rev. 0

Attachment B: REDOX (Original "GT Strudl" Model) Output for Seismic Analysis

(Using Original Ground Aesponse Spectrum for 10\% Damping)

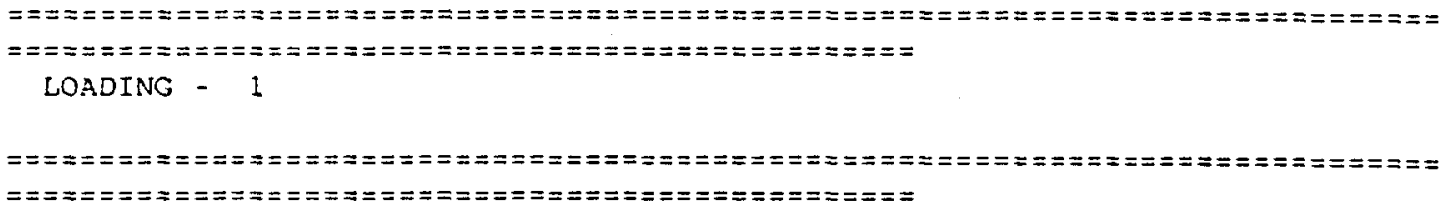

SPECTRAL ACCELERATIONS

\begin{tabular}{|c|c|c|c|c|c|c|c|c|}
\hline \multicolumn{2}{|c|}{ MODE } & $\mathrm{ACC}$ & MODE & ACC & MODE & ACC & MODE & ACC \\
\hline \multicolumn{2}{|c|}{ MODE } & ACC & MODE & $A C C$ & & & & \\
\hline 1 & 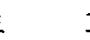 & 3.687696 & 2 & 6.440001 & 3 & 6.440000 & 4 & 6.440000 \\
\hline \multirow[t]{2}{*}{5} & 6.4 & 40001 & 6 & 6.131038 & & & & \\
\hline & 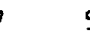 & 5.847721 & 8 & 5.641710 & 9 & 5.216498 & 10 & 5.123625 \\
\hline 11 & 4.7 & 776242 & 12 & 4.602650 & & & & \\
\hline 13 & & 4.595957 & 14 & 4.559378 & 15 & 4.377673 & 16 & 4.377247 \\
\hline 17 & 4.7 & 355112 & 18 & 4.248522 & & & & \\
\hline 19 & & 4.229773 & 20 & 4. 112922 & 21 & 4.056123 & 22 & 4.028389 \\
\hline 23 & 3.5 & 931003 & 24 & 3.916789 & & & & \\
\hline 1 & $454\}$ & $>$ LIST & RESPONSE & SPECTRUM FORCES & $s-$ & & & \\
\hline $\mathfrak{l}$ & 4551 & $>_{-}$MODE & E COMBINA & TION NRC TPM M & 1EMBERS & ALL & . & \\
\hline
\end{tabular}

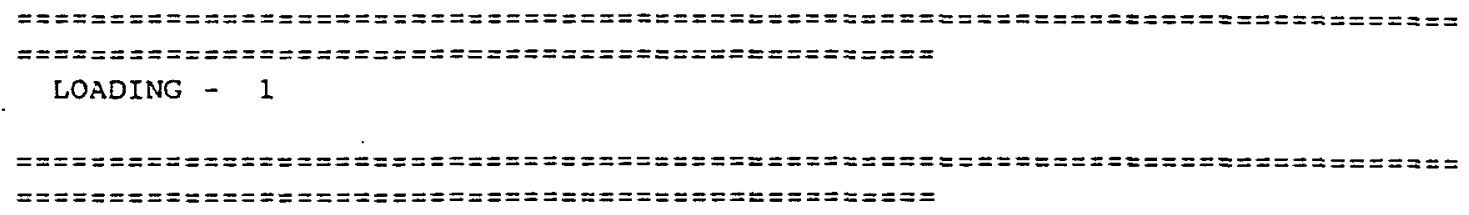

MEMBER FORCES

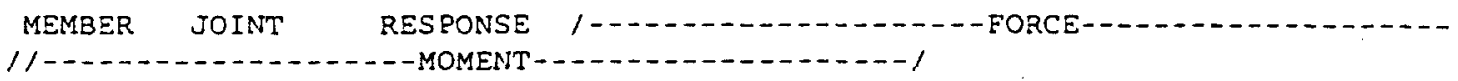


Attachment B: REDOX (Original "GT Strudl" Model) Output for Seismic Analysis (Using Original Ground Response Spectrum for 10\% Damping)

\begin{tabular}{|c|c|c|c|c|c|}
\hline TORS IONAL & & $\begin{array}{l}\text { TYPE } \\
\text { BENDING }-Y\end{array}$ & $\begin{array}{r}\text { AXIAL } \\
\text { BENDING-Z }\end{array}$ & SHEAR-Y & SHEAR-Z \\
\hline $\begin{array}{l}1 \\
723.9748\end{array}$ & 1 & NRC TPM & 162.5270 & 26.54026 & \\
\hline$\stackrel{1}{601.5921}$ & 2 & NRC TPM & 162.5270 & 26.54026 & \\
\hline $\begin{array}{l}2 \\
601.5921\end{array}$ & 2 & NRC TPM & 162.5169 & 26.39308 & \\
\hline $\begin{array}{l}2 \\
481.6094\end{array}$ & 3 & NRC TPM & 162.5169 & 26.39308 & \\
\hline $\begin{array}{l}3 \\
481.6094\end{array}$ & 3 & NRC TPM & 162.4966 & 25.90502 & \\
\hline $3^{3} 66.9013$ & 4 & NRC TPM & 162.4966 & 25.90502 & \\
\hline $\begin{array}{l}4 \\
464.6790\end{array}$ & 4 & NRC TPM & 151.8851 & 25.46727 & \\
\hline $\begin{array}{l}4 \\
386.0259\end{array}$ & 5 & NRC TPM & 151.8851 & 25.46727 & \\
\hline $\begin{array}{l}5 \\
386.0259\end{array}$ & 5 & NRC TPM & 151.8522 & 24.33854 & \\
\hline $\begin{array}{c}5 \\
323.7255\end{array}$ & 6 & NRC TPM & 151.8522 & 24.33854 & \\
\hline $\begin{array}{l}5 \\
323.7255\end{array}$ & 6 & NRC TPM & 151.8127 & 22.92231 & \\
\hline $\begin{array}{l}6 \\
285.4577\end{array}$ & 7 & NRC TPM & 151.8127 & 22.92231 & \\
\hline $\begin{array}{l}7 \\
414.4480\end{array}$ & 7 & NRC TPM & 135.4492 & 31.68467 & \\
\hline $\begin{array}{l}7 \\
320.7210\end{array}$ & 8 & NRC TPM & 135.4492 & 31.68467 & \\
\hline $\begin{array}{l}8 \\
320.7210\end{array}$ & 8 & NRC TPM & 235.3956 & 28.87152 & \\
\hline $\begin{array}{c}8 \\
260.6539\end{array}$ & 9 & NRC TPM & 135.3956 & 28.87152 & \\
\hline 9290.6539 & 9 & NRC TPM & 135.3362 & 25.48639 & \\
\hline $\begin{array}{c}9 \\
244.0547\end{array}$ & 10 & NRC TPM & 135.3362 & 25.48639 & \\
\hline
\end{tabular}

ATTTACHMENT-B: Calc. No. $0200 W-C A-C 0156$ Rev. No. 0 Job No. 22192 
Attachment B: REDOX (Original "GT Strudl" Model) Output for Seismic Analysis (Using Original Ground Response Spectrum for 10\% Damping)

\begin{tabular}{|c|c|c|c|c|c|}
\hline $\begin{array}{l}10 \\
371.3631\end{array}$ & 10 & NRC & TPM & 110.3275 & 33.78887 \\
\hline $\begin{array}{l}10 \\
410.8623\end{array}$ & 11 & NRC & $T P M$ & 110.3275 & 33.78887 \\
\hline $\begin{array}{c}11 \\
410.8623\end{array}$ & 11 & NRC & TPM & 110.1817 & 29.44501 \\
\hline $\begin{array}{l}11 \\
435.5901\end{array}$ & 12 & NRC & TPM & 110.1817 & 29.44501 \\
\hline $\begin{array}{l}12 \\
435.5901\end{array}$ & 12 & NRC & $T P M$ & 110.0114 & 23.55810 \\
\hline $\begin{array}{l}12 \\
508.1829\end{array}$ & 13 & NRC & TPM & 110.0114 & 23.55810 \\
\hline $\begin{array}{l}13 \\
1275.257\end{array}$ & 13 & NRC & TPM & 15.11513 & 66.60932 \\
\hline $\begin{array}{c}13 \\
994.9907\end{array}$ & 14 & NRC & TPM & 15.11513 & 66.60932 \\
\hline $\begin{array}{l}14 \\
994.9907\end{array}$ & 14 & NRC & TPM & 15.02906 & 59.04925 \\
\hline $\begin{array}{l}14 \\
746.0487\end{array}$ & 15 & NRC & $T P M$ & 15.02906 & 59.04925 \\
\hline $\begin{array}{l}15 \\
746.0487\end{array}$ & 15 & NRC & $\mathrm{TPM}$ & 26.17626 & 48.20427 \\
\hline $\begin{array}{l}15 \\
656.7941\end{array}$ & 16 & NRC & TPM & 26.17626 & 48.20427 \\
\hline $\begin{array}{l}16 \\
666.7941\end{array}$ & 16 & NRC & TPM & 14.88747 & 48.30655 \\
\hline $\begin{array}{l}16 \\
438.4806\end{array}$ & 17 & NRC & TPM & 14.88747 & 48.30655 \\
\hline $\begin{array}{l}17 \\
438.4806\end{array}$ & 17 & NRC & TPM & 14.79764 & 41.66020 \\
\hline $\begin{array}{l}17 \\
241.5442\end{array}$ & 18 & NRC & TPM & 14.79764 & 41.66020 \\
\hline $\begin{array}{l}18 \\
241.5442\end{array}$ & 18 & NRC & $\mathrm{TPM}$ & 14.71808 & 32.82532 \\
\hline $\begin{array}{l}18 \\
88.16195\end{array}$ & 19 & NRC & TPM & 14.71808 & 32.82532 \\
\hline $\begin{array}{l}19 \\
15.92260\end{array}$ & 19 & NRC & TPM & 9.195590 & 3.116371 \\
\hline
\end{tabular}

\section{Sheet B21 of B35}

ATTTACHMENT-B: Calc. No. 0200W-CA-C0156 Rev. No. 0 Job No. 22192 
Attachment B: REDOX (Original "GT Strudl" Model) Output for Seismic Analysis (Using Original Ground Response Spectrum for 10\% Damping)

\begin{tabular}{|c|c|c|c|c|c|}
\hline $\begin{array}{l}19 \\
13.15434\end{array}$ & 20 & $\mathrm{NRC}$ & $T P M$ & 9.195590 & 3.116371 \\
\hline $\begin{array}{l}20 \\
85.37629\end{array}$ & 20 & $\mathrm{NRC}$ & $\mathrm{TPM}$ & 23.54141 & 12.54457 \\
\hline $\begin{array}{l}20 \\
26.14533\end{array}$ & 21 & NRC & TPM & 23.54141 & 12.54457 \\
\hline $\begin{array}{l}21 \\
26.14532\end{array}$ & 21 & NRC & TPM & 23.73512 & 5.504276 \\
\hline $\begin{array}{l}21 \\
0.7126374 E\end{array}$ & $\begin{array}{l}22 \\
E-05\end{array}$ & NRC & TPM & 23.73512 & 5.504275 \\
\hline $\begin{array}{c}101 \\
4215.954\end{array}$ & 101 & NRC & TPM & 160.8116 & 128.0982 \\
\hline $\begin{array}{l}101 \\
3636.893\end{array}$ & 102 & NRC & TPM & 160.8116 & 128.0982 \\
\hline $\begin{array}{l}102 \\
3636.893\end{array}$ & 102 & NRC & TPM & 160.8033 & 127.8320 \\
\hline $\begin{array}{l}102 \\
3070.140\end{array}$ & 103 & NRC & TPM & 160.8033 & 127.8320 \\
\hline $\begin{array}{l}103 \\
3070.140\end{array}$ & 103 & NRC & TPM & 160.7868 & 126.9357 \\
\hline $\begin{array}{l}103 \\
2525.370\end{array}$ & 104 & NRC & TPM & 160.7868 & 126.9357 \\
\hline $\begin{array}{l}104 \\
2623.186\end{array}$ & 104 & NRC & TPM & 150.0263 & 124.2010 \\
\hline $\begin{array}{l}104 \\
2183.218\end{array}$ & 105 & NRC & TPM & 150.0263 & 124.2010 \\
\hline $\begin{array}{l}105 \\
2183.218\end{array}$ & 105 & NRC & TPM & 149.9996 & 122.1202 \\
\hline $\begin{array}{r}105 \\
1779.877\end{array}$ & 106 & NRC & TPM & 149.9996 & 122.1202 \\
\hline $\begin{array}{l}106 \\
1779.877\end{array}$ & 106 & NRC & TPM & 149.9674 & 119.3006 \\
\hline $\begin{array}{r}106 \\
1438.436\end{array}$ & 107 & $\mathrm{NRC}$ & TPM & 149.9674 & 119.3006 \\
\hline $\begin{array}{l}107 \\
1571.013\end{array}$ & 107 & NRC & TPM & 133.3757 & 105.3932 \\
\hline $\begin{array}{l}107 \\
1380.694\end{array}$ & 108 & NRC & TPM & 133.3757 & 105.3932 \\
\hline
\end{tabular}


Attachment B: REDOX (Original "GT Strudl" Model) Output for Seismic Analysis (Using Original Ground Response Spectrum for 10\% Damping)

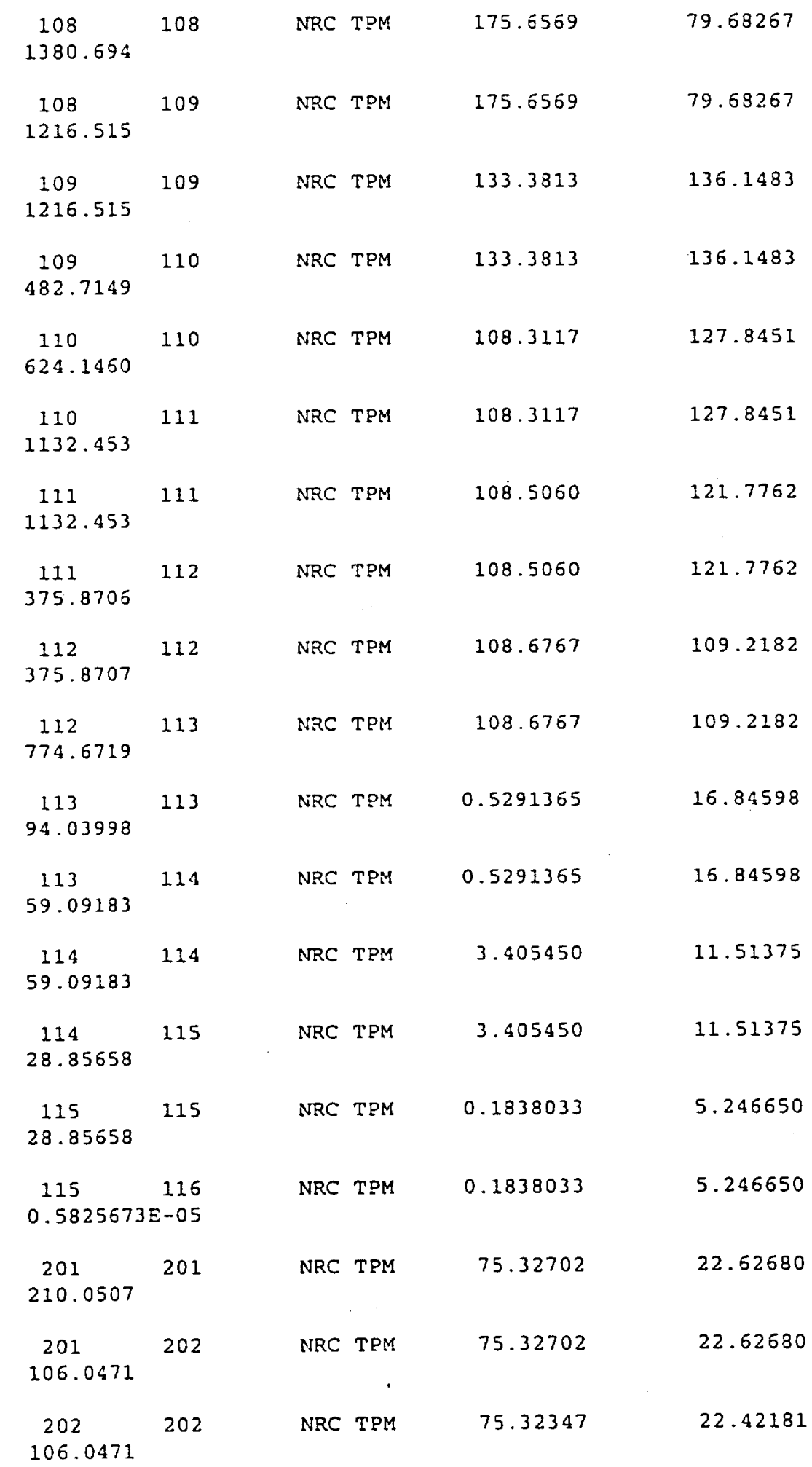

ATTTACHMENT-B: Calc. No. 0200W-CA-C0156 Rev. No. 0 Job No. 22192 
Attachment B: REDOX (Original "GT Strudl" Model) Output for Seismic Analysis

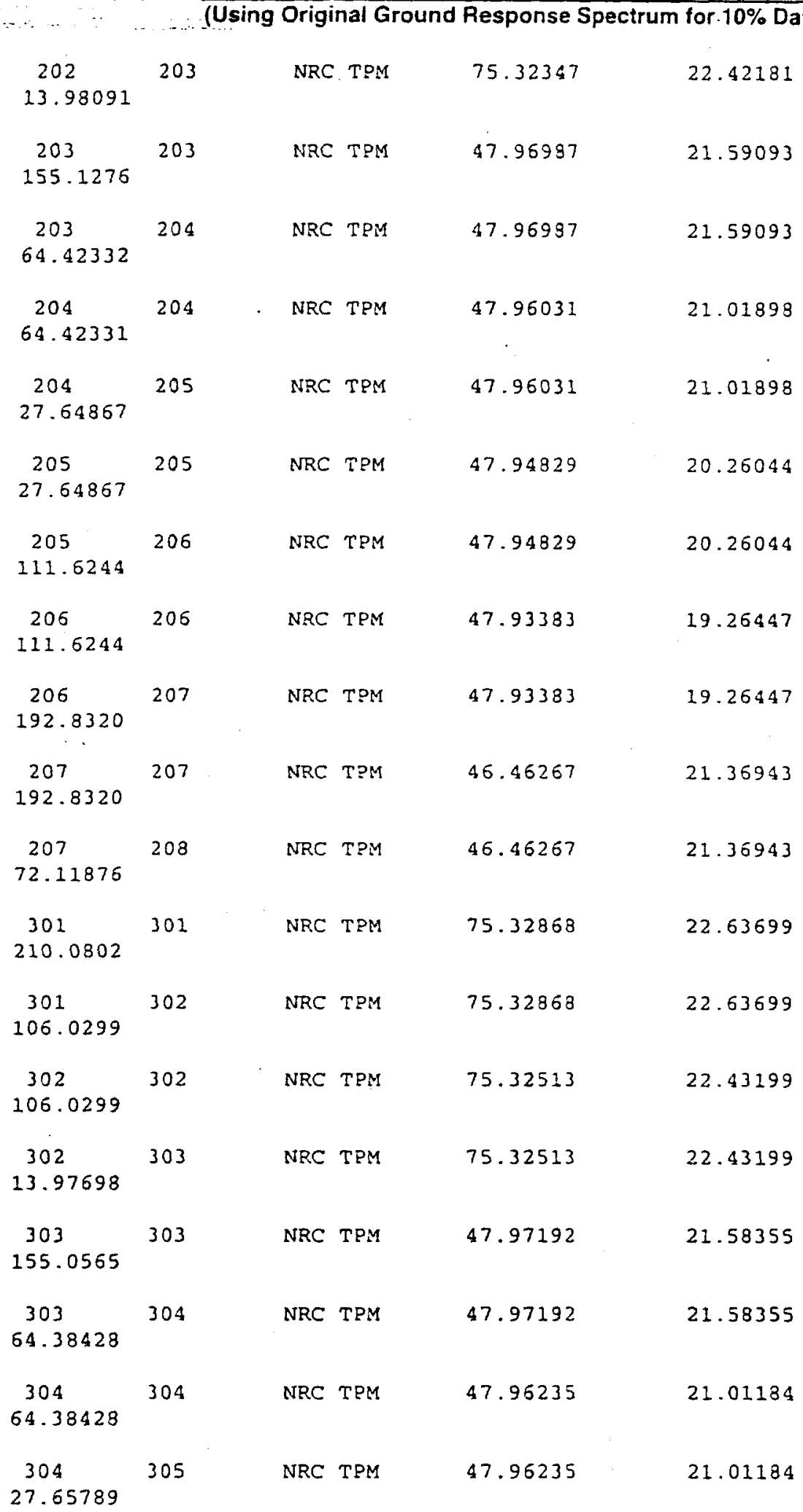

ATTTACHMENT-B: Calc. No. 0200W-CA-C0156 Rev. No. 0 Job No. 22192 
BHI-01299

Rev. 0

Attachment B: REDOX (Original "GT Strudl" Model) Output for Seismic Analysis (Using Original Ground Response Spectrum for 10\% Damping)

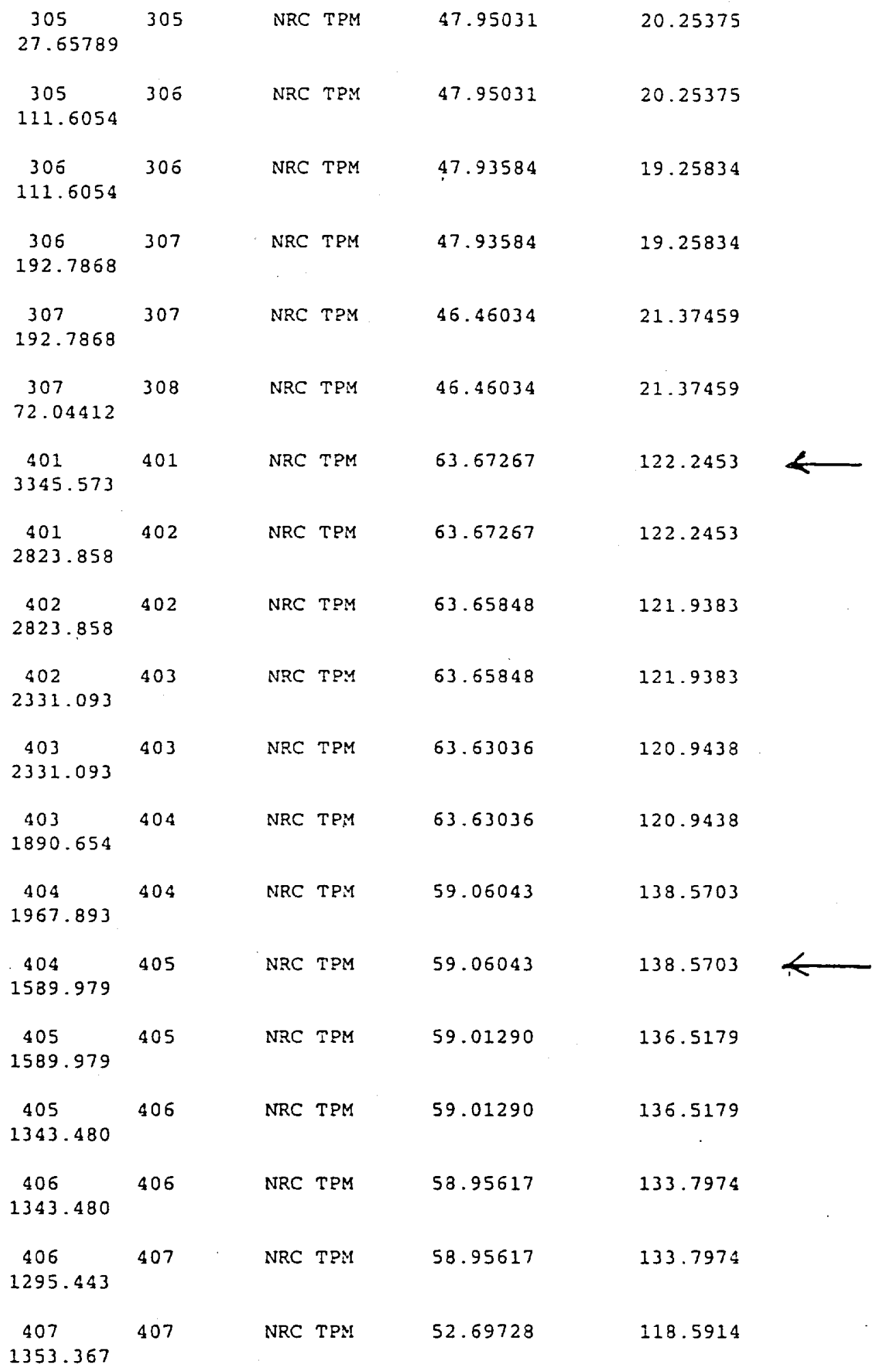

ATTIACHMENT-B: Calc. No. 0200W-CA-C0156 Rev. No. 0 Job No. 22192 
BHI-01299

Rev. 0

Attachment B: REDOX (Original "GT Strudl" Model) Output for Seismic Analysis (Using Original Ground Response Spectrum for 10\% Damping)

\begin{tabular}{|c|c|c|c|c|c|}
\hline $\begin{array}{l}407 \\
1458.175\end{array}$ & 408 & NRC & TPM & 52.69728 & 118.5914 \\
\hline $\begin{array}{l}408 \\
1458.176\end{array}$ & 408 & NRC & TPM & 90.19257 & 52.77518 \\
\hline $\begin{array}{l}408 \\
1331.076\end{array}$ & 409 & NRC & TPM & 90.19257 & 52.77518 \\
\hline $\begin{array}{l}409 \\
1331.076\end{array}$ & 409 & NRC & TPM & 52.58089 & 87.78625 \\
\hline $\begin{array}{c}409 \\
1070.753\end{array}$ & 410 & NRC & TPM & 52.58089 & 87.78625 \\
\hline $\begin{array}{l}410 \\
1149.460\end{array}$ & 410 & NRC & TPM & 38.44527 & 49.40107 \\
\hline $\begin{array}{l}410 \\
1038.229\end{array}$ & 411 & NRC & TPM & 38.44527 & 49.40107 \\
\hline $\begin{array}{l}411 \\
1038.229\end{array}$ & 411 & NRC & TPM & 38.48089 & 45.00646 \\
\hline $\begin{array}{c}411 \\
954.5264\end{array}$ & 412 & NRC & TQM & 38.48089 & 45.00645 \\
\hline $\begin{array}{c}412 \\
954.5264\end{array}$ & 412 & NRC & TPM & 38.52438 & 39.85139 \\
\hline $\begin{array}{c}412 \\
892.0784\end{array}$ & 413 & NRC & TPM & 38.52438 & 39.85139 \\
\hline $\begin{array}{l}413 \\
892.0734\end{array}$ & 413 & NRC & TPM & 38.57757 & 34.16879 \\
\hline $\begin{array}{c}413 \\
839.9167\end{array}$ & 414 & NRC & TPM & 38.57757 & 34.16879 \\
\hline $\begin{array}{l}414 \\
1121.454\end{array}$ & 416 & NRC & TPM & 14.55901 & 49.87020 \\
\hline $\begin{array}{r}414 \\
1022.515\end{array}$ & 415 & NRC & TPM & 14.55901 & 49.87020 \\
\hline $\begin{array}{r}415 \\
1022.515\end{array}$ & 415 & NRC & TPM & 23.87736 & 45.76763 \\
\hline $\begin{array}{l}415 \\
950.0551\end{array}$ & 416 & NRC & TPM & 23.87736 & 45.76763 \\
\hline $\begin{array}{l}416 \\
950.0551\end{array}$ & 416 & NRC & TPM & 14.25832 & 49.57498 \\
\hline $\begin{array}{c}416 \\
720.2843\end{array}$ & 417 & NRC & TPM & 14.25832 & 49.57498 \\
\hline
\end{tabular}

ATTTACHMENT-B: Calc. No. 0200W-CA-C0156 Rev. No. 0 Job No. 22192 
BHI-01299

Rev. 0

Attachment B: REDOX (Original "GT Strudl" Model) Output for Seismic Analysis (Using Original Ground Response Spectrum for 10\% Damping)

\begin{tabular}{|c|c|c|c|c|c|}
\hline $\begin{array}{l}417 \\
720.2843\end{array}$ & 417 & NRC & TPM & 14.10621 & 49.50992 \\
\hline $\begin{array}{c}417 \\
487.6787\end{array}$ & 418 & NRC & TPM & 14.10621 & 49.50992 \\
\hline $\begin{array}{c}418 \\
487.6787\end{array}$ & 418 & NRC & TPM & 13.96323 & 48.87549 \\
\hline $\begin{array}{l}418 \\
261.2441\end{array}$ & 419 & NRC & TPM & 13.96323 & 48.87549 \\
\hline $\begin{array}{c}419 \\
47.48839\end{array}$ & 419 & NRC & TPM & 15.10577 & 14.28569 \\
\hline $\begin{array}{l}419 \\
34.66214\end{array}$ & 420 & NRC & TPM & 15.10577 & 14.28569 \\
\hline $\begin{array}{l}420 \\
212.2877\end{array}$ & 420 & NRC & TPM & 14.92581 & 45.38221 \\
\hline $\begin{array}{l}420 \\
26.65198\end{array}$ & 421 & NRC & $T P M$ & 14.92581 & 45.38221 \\
\hline $\begin{array}{c}421 \\
26.65198\end{array}$ & 421 & NRC & TPM & 14.91121 & 44.09769 \\
\hline $\begin{array}{l}421 \\
215.2592\end{array}$ & 422 & NRC & TPM & 14.91121 & 44.09769 \\
\hline $\begin{array}{l}502 \\
248.8355\end{array}$ & 502 & NRC & ТРМ & 68.94424 & 30.43464 \\
\hline $\begin{array}{c}502 \\
105.0501\end{array}$ & 503 & NRC & TPM & 68.94424 & 30.43464 \\
\hline $\begin{array}{l}503 \\
105.0501\end{array}$ & 503 & NRC & TPM & 68.93934 & 30.20913 \\
\hline $\begin{array}{l}503 \\
40.84610\end{array}$ & 504 & NRC & T?M & 68.93934 & 30.20913 \\
\hline $\begin{array}{l}504 \\
49.04579\end{array}$ & 504 & NRC & TPM & 63.99935 & 7.202723 \\
\hline $\begin{array}{l}504 \\
27.93317\end{array}$ & 505 & NRC & TPM & 63.99935 & 7.202723 \\
\hline $\begin{array}{l}505 \\
27.93317\end{array}$ & 505 & NRC & TPM & 63.98718 & 6.209117 \\
\hline $\begin{array}{l}505 \\
24.07066\end{array}$ & 506 & NRC & TPM & 63.98718 & 6.209117 \\
\hline $\begin{array}{l}506 \\
24.07065\end{array}$ & 506 & & TPM & 63.97163 & 5.470551 \\
\hline
\end{tabular}


Attachment B: REDOX (Original "GT Strudl" Model) Output for Seismic Analysis (Using Original Ground Response Spectrum for 10\% Damping)

\begin{tabular}{|c|c|c|c|c|c|}
\hline $\begin{array}{l}505 \\
35.79412\end{array}$ & 507 & NRC & $T P M$ & 63.97163 & 5.470561 \\
\hline $\begin{array}{l}507 \\
83.52233\end{array}$ & 507 & NRC & T?M & 57.04204 & 11.99370 \\
\hline $\begin{array}{l}507 \\
67.63642\end{array}$ & 508 & NRC & $T P Y$ & 57.04204 & 11.99370 \\
\hline $\begin{array}{l}508 \\
67.63641\end{array}$ & 508 & NRC & TPM & 57.01882 & 10.22073 \\
\hline $\begin{array}{l}508 \\
79.53875\end{array}$ & 509 & NRC & TPY & 57.01882 & 10.22073 \\
\hline $\begin{array}{l}509 \\
79.53875\end{array}$ & 509 & NRC & TPM & 56.99268 & 8.307423 \\
\hline $\begin{array}{l}509 \\
102.3637\end{array}$ & 510 & NRC & TPM & 56.99268 & 8.307423 \\
\hline $\begin{array}{c}510 \\
221.8341\end{array}$ & 510 & NRC & $T P M$ & 41.23708 & 33.33727 \\
\hline $\begin{array}{l}510 \\
79.00789\end{array}$ & 511 & NRC & $T P M$ & 41.23708 & 33.33727 \\
\hline $\begin{array}{l}511 \\
79.00789\end{array}$ & 511 & NRC & $\mathrm{TPM}$ & 41.20670 & 31.40112 \\
\hline $\begin{array}{c}511 \\
8 \dot{3} .70372\end{array}$ & 512 & NRC & $T P M$ & 41.20670 & 31.40112 \\
\hline $\begin{array}{c}512 \\
83.70372\end{array}$ & 512 & $\mathrm{NRC}$ & TPM & 41.17549 & 29.29694 \\
\hline $\begin{array}{l}512 \\
208.2919\end{array}$ & 513 & NRC & TPM & 41.17549 & 29.29694 \\
\hline $\begin{array}{l}513 \\
208.2919\end{array}$ & 513 & NRC & $T P M$ & 41.14391 & 27.40430 \\
\hline $\begin{array}{l}513 \\
327.7747\end{array}$ & 514 & NRC & TPY & 41.14381 & 27.40430 \\
\hline $\begin{array}{c}\text { MS1-1 } \\
98.74975\end{array}$ & 104 & NRC & TPM & 6.620917 & 11.64965 \\
\hline $\begin{array}{c}M S 1-1 \\
33.05723\end{array}$ & $51-1$ & NRC & TPM & 6.620917 & 11.64965 \\
\hline $\begin{array}{c}\text { MS1-2 } \\
33.05723\end{array}$ & $51-1$ & NRC & TPM & 6.298756 & 11.69917 \\
\hline $\begin{array}{l}M S 1-2 \\
32.90918\end{array}$ & $\$ 1-2$ & NRC & TRM & 6.298756 & 11.69917 \\
\hline
\end{tabular}

\section{Sheet B28 of B35}

ATTTACHMENT-B: Calc. No. 0200W-CA-C0156 Rev. No. 0 Job No. 22192 
BHI-01299

Rev. 0

Attachment B: REDOX (Original "GT Strudl" Model) Output for Seismic Analysis

(Using Original Ground Response Spectrum for 10\% Damping)

\begin{tabular}{|c|c|c|c|c|c|}
\hline $\begin{array}{c}\text { MS1-3 } \\
32.90918\end{array}$ & $S 1-2$ & NRC & TPM & 6.030550 & 11.65252 \\
\hline $\begin{array}{l}\text { MS1-3 } \\
98.61684\end{array}$ & 4 & NRC & $T P M$ & 6.030550 & 11.65252 \\
\hline $\begin{array}{c}M S 2-1 \\
147.3557\end{array}$ & 107 & NRC & $\mathrm{TPM}$ & 21.74870 & 17.47443 \\
\hline $\begin{array}{c}\text { MS2-1 } \\
48.82403\end{array}$ & $s 2-1$ & NRC & $T P M$ & 21.74870 & 17.47443 \\
\hline $\begin{array}{c}\text { MS2-2 } \\
48.82403\end{array}$ & $s 2-1$ & NRC & TPM & 20.79790 & 17.54149 \\
\hline $\begin{array}{c}\text { MS2-2 } \\
50.09531\end{array}$ & $s 2-2$ & NRC & TPM & 20.79790 & 17.54149 \\
\hline $\begin{array}{c}\text { MS2-3 } \\
50.09531\end{array}$ & $s 2-2$ & NRC & TPM & 19.86061 & 17.47210 \\
\hline $\begin{array}{c}\text { MS2-3 } \\
148.6055\end{array}$ & 7 & NRC & TPM & 19.86061 & 17.47210 \\
\hline $\begin{array}{c}\text { MS3-1 } \\
208.5705\end{array}$ & 110 & NRC & TPM & 24.07740 & 25.64693 \\
\hline $\begin{array}{c}M S 3-1 \\
85.32948\end{array}$ & $53-1$ & NRC & $T P M$ & 24.07740 & 25.64693 \\
\hline $\begin{array}{c}\text { MS3-2 } \\
85.32948\end{array}$ & $53-1$ & NRC & $T P: 4$ & 23.32876 & 25.78790 \\
\hline $\begin{array}{c}M S 3-2 \\
60.08401\end{array}$ & $53-2$ & NRC & TPY & 23.32876 & 25.78790 \\
\hline $\begin{array}{l}\text { MS3-3 } \\
60.08402\end{array}$ & $s 3-2$ & NRC & TPY & 22.66013 & 25.74021 \\
\hline $\begin{array}{c}\text { MS3-3 } \\
205.2216\end{array}$ & 10 & NRC & TPM & 22.66013 & 25.74021 \\
\hline $\begin{array}{c}\text { MS4-1 } \\
852.8647\end{array}$ & 113 & NRC & TPM & 89.31910 & 109.1345 \\
\hline $\begin{array}{c}\text { MS4-1 } \\
328.6524\end{array}$ & $S 4-1$ & NRC & TPM & 89.31910 & 109.1345 \\
\hline $\begin{array}{c}\text { MS4-2 } \\
328.6524\end{array}$ & $54-1$ & NRC & TPM & 85.99980 & 109.3420 \\
\hline $\begin{array}{c}\text { MS4-2 } \\
288.7262\end{array}$ & $54-2$ & NRC & TPM & 85.99980 & 109.3420 \\
\hline $\begin{array}{c}M S 4-3 \\
288.7262\end{array}$ & $54-2$ & NRC & TPM & 82.52366 & 109.1630 \\
\hline
\end{tabular}

ATTTACHMENT-B: Calc. No. 0200W-CA-C0156 Rev. No. 0 Job No. 22192 
BHI-01299

Rev. 0

Attachment B: $\frac{\text { AEDOX (Original "GT Strudl" Model) Output for Seismic Analysis }}{\text { (Using Original Ground Response Spectrum for } 10 \% \text { Damping) }}$

\begin{tabular}{|c|c|c|c|c|c|}
\hline $\begin{array}{c}\text { MS4-3 } \\
903.9714\end{array}$ & 13 & NRC & TPM & 82.52366 & 109.1630 \\
\hline $\begin{array}{c}\text { MS5-1 } \\
79.72475\end{array}$ & 404 & NRC & TPM & 22.04126 & 7.128978 \\
\hline $\begin{array}{c}\text { MSS-1 } \\
25.64626\end{array}$ & $55-1$ & NRC & TPM & 22.04126 & 7.128978 \\
\hline $\begin{array}{c}\text { MS5-2 } \\
25.64626\end{array}$ & $S 5-1$ & NRC & TPM & 22.27713 & 7.193459 \\
\hline $\begin{array}{c}M S 5-2 \\
29.18155\end{array}$ & $55-2$ & NRC & TPM & 22.27713 & 7.193459 \\
\hline $\begin{array}{c}\text { MS5-3 } \\
29.18155\end{array}$ & ss-2 & NRC & TPH & 22.57224 & 7.081993 \\
\hline $\begin{array}{c}\text { MS5-3 } \\
82.95523\end{array}$ & 504 & NRC & TPM & 22.57224 & 7.081993 \\
\hline $\begin{array}{c}\text { MS6-1 } \\
103.4544\end{array}$ & 407 & NRC & TPM & 14.04726 & 8.845980 \\
\hline $\begin{array}{c}\text { MS6-1 } \\
36.22622\end{array}$ & $56-1$ & NRC & TPM & 14.04726 & 8.845980 \\
\hline $\begin{array}{c}M S 6-2 \\
36.22622\end{array}$ & $56-1$ & NRC & TPM & 12.33524 & 8.977871 \\
\hline $\begin{array}{c}M S 6-2 \\
32.14117\end{array}$ & $s 6-2$ & NRC & TPM & 12.33524 & 8.977871 \\
\hline $\begin{array}{c}\text { MS6-3 } \\
32.14117\end{array}$ & $s 6-2$ & NRC & TPM & 10.63202 & 8.888132 \\
\hline $\begin{array}{c}\text { MS6-3 } \\
99.72919\end{array}$ & 507 & NRC & TPM & 10.63202 & 8.888132 \\
\hline $\begin{array}{c}M S 7-1 \\
167.0196\end{array}$ & 410 & NRC & TPM & 36.97212 & 16.36041 \\
\hline $\begin{array}{c}\text { MS7-1 } \\
\text { B1.19668 }\end{array}$ & $57-1$ & NRC & TPM & 36.97212 & 16.36041 \\
\hline $\begin{array}{c}\text { MS7-2 } \\
81.19668\end{array}$ & $57-1$ & NRC & TPM & 35.90671 & 16.46867 \\
\hline $\begin{array}{c}\text { MS7-2 } \\
44.61335\end{array}$ & $s 7-2$ & NRC & $T P M$ & 35.90671 & 16.46867 \\
\hline $\begin{array}{c}\text { MS7-3 } \\
44.61335\end{array}$ & $57-2$ & NRC & TPM & 34.82758 & 16.56484 \\
\hline $\begin{array}{l}\text { MST-3 } \\
169.3819\end{array}$ & 510 & NRC & TP:4 & 34.82758 & 16.56484 \\
\hline
\end{tabular}

ATTTACHMENT-B: Calc. No. 0200W-CA-C0156 Rev. No. 0 Job No. 22192 
BHI-01299

Rev. 0

Attachment B: REDOX (Original "GT Strudl" Model) Output for Seismic Analysis

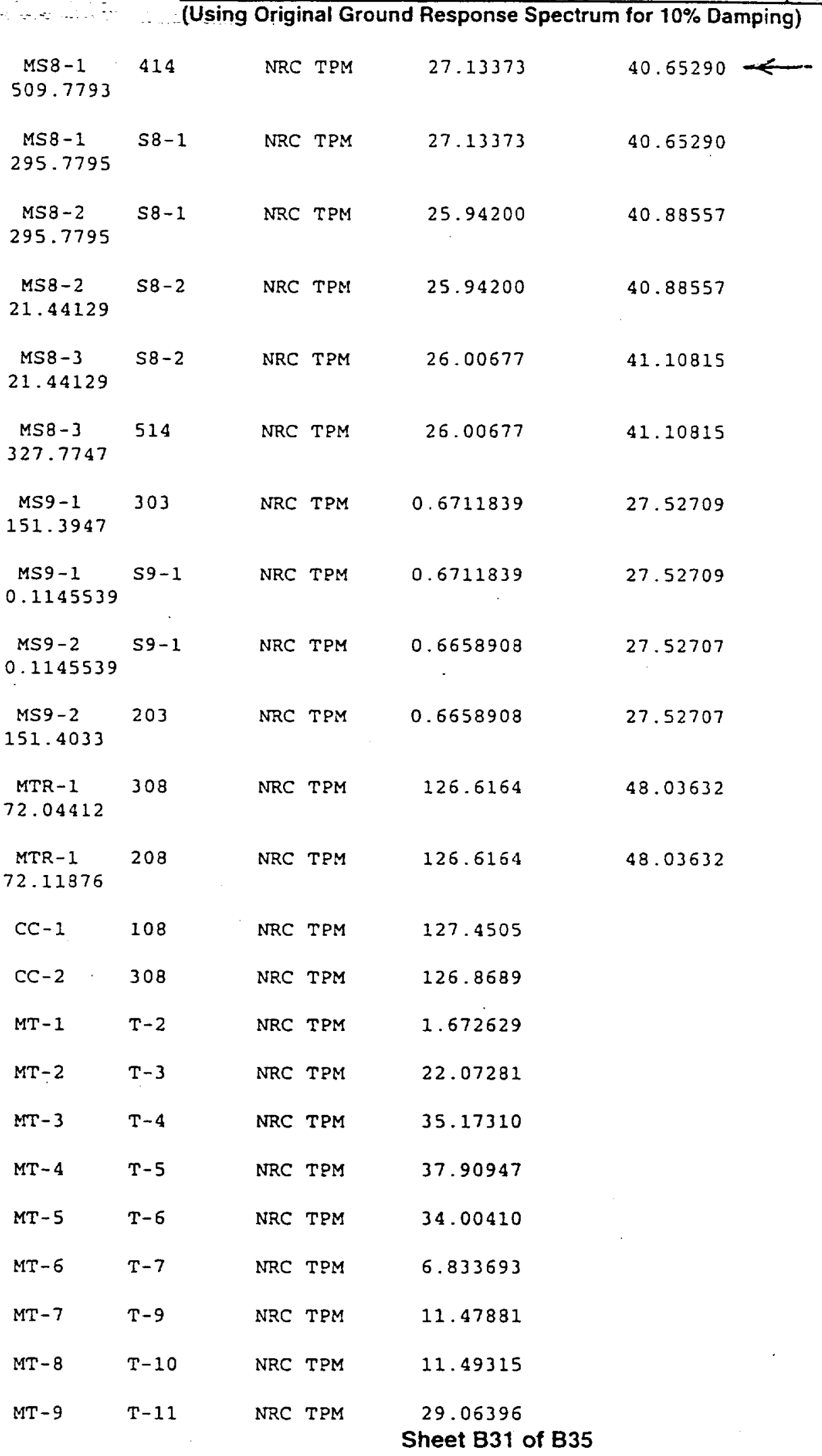

ATTTACHMENT-B: Calc. No. 0200 W-CA-C0156 Rev. No. 0 Job No. 22192 
Attachment B: REDOX (Original "GT Strudl" Model) Output for Seismic Analysis

(Using Original Ground Response Spectrum for 10\% Damping)

\begin{tabular}{|c|c|c|c|c|c|}
\hline$M T-10$ & $T-12$ & NRC & $T P M$ & 29.07311 & \\
\hline $\mathrm{MT}-11$ & $\mathrm{~T}-13$ & $\mathrm{NRC}$ & TPM & 37.21357 & \\
\hline$M T-12$ & $T-14$ & NRC & TPM & 37.21556 & \\
\hline$M T-13$ & $\mathrm{~T}-15$ & NRC & $T P M$ & 35.38402 & \\
\hline$M T-14$ & $\mathrm{~T}-16$ & NRC & TPM & 35.37710 & \\
\hline $\mathrm{MT}-15$ & $T-17$ & NRC & TPM & 23.80730 & \\
\hline$M T-16$ & $\mathrm{~T}-18$ & NRC & TPM & 23.79427 & \\
\hline$M T-17$ & $T-8$ & NRC & TPM & 25.85523 & \\
\hline$M T-18$ & $T-8$ & NRC & TPM & 18.38594 & \\
\hline$M T-19$ & $\mathrm{~T}-9$ & NRC & TPM & 1.442800 & \\
\hline$M T-20$ & $T-10$ & NRC & $T P M$ & 16.78898 & \\
\hline$M T-21$ & $T-10$ & NRC & TPM & 11.78879 & \\
\hline$M T-22$ & $T-11$ & NRC & TPM & 1.926043 & \\
\hline$M T-23$ & $T-12$ & NRC & TPM & 9.815539 & \\
\hline$M T-24$ & $T-12$ & NRC & TPM & 5.252880 & \\
\hline $\mathrm{MT}-25$ & $T-13$ & NRC & TPM & 2.775547 & \\
\hline MT-26 & $T-14$ & NRC & TPM & 4.843285 & \\
\hline$M T-27$ & $T-14$ & NRC & TPM & 9.349350 & \\
\hline$M T-28$ & $T-15$ & NRC & TPM & 1.963156 & \\
\hline$M T-29$ & $T-16$ & NRC & TPM & 11.65069 & \\
\hline$M T-30$ & $T-16$ & NRC & $T P M$ & 17.70263 & \\
\hline$M T-31$ & $T-17$ & NRC & TPM & 20.12969 & \\
\hline $\mathrm{MT}-32$ & $\mathrm{~T}-18$ & NRC & $T P M$ & 38.13107 & \\
\hline$M T-33$ & $T-18$ & NRC & TPM & 17.99386 & \\
\hline $\begin{array}{c}\text { MTC-1 } \\
72.24883\end{array}$ & 19 & NRC & $T P M$ & 15.65422 & 14.76269 \\
\hline $\begin{array}{c}\text { MTC-1 } \\
59.28920\end{array}$ & 30 & NRC & TPM & 15.65422 & 14.76269 \\
\hline $\begin{array}{c}\text { MTC-2 } \\
72.23995\end{array}$ & 20 & NRC & TPM & 12.65717 & 17.88136 \\
\hline
\end{tabular}

ATTACHMENT-B: Calc. No. 0200W-CA-C0156 Rev. No. 0 Job No. 22192 
Attachment B: REDOX (Original "GT Strudl" Model) Output for Seismic Analysis

$\ldots \ldots \ldots$... (Using Original Ground Response Spectrum for 10\% Damping)

\begin{tabular}{|c|c|c|c|c|c|}
\hline $\begin{array}{c}\text { MTC - } 2 \\
59.28920\end{array}$ & 30 & $\mathrm{NRC}$ & TPM & 12.65717 & 17.88136 \\
\hline $\begin{array}{c}\text { MTC-11 } \\
213.7623\end{array}$ & 419 & $\mathrm{NRC}$ & TPM & 13.24266 & 44.66620 \\
\hline $\begin{array}{c}M T C-11 \\
174.0684\end{array}$ & 430 & NRC & TPM & 13.24266 & 44.66620 \\
\hline $\begin{array}{c}\text { MTC-12 } \\
177.6389\end{array}$ & 420 & NRC & TPM & 39.64884 & 4.893496 \\
\hline $\begin{array}{c}\text { MTC }-12 \\
174.1316\end{array}$ & 430 & NRC & TPM & 39.64884 & 4.893496 \\
\hline $\begin{array}{c}\text { MTC-13 } \\
4.542029\end{array}$ & 430 & NRC & TPM & 18.01954 & 8.385284 \\
\hline $\begin{array}{c}\text { MTC }-13 \\
0.2890849\end{array}$ & $\begin{array}{l}T-7 \\
-07\end{array}$ & NRC & TPM & 18.01954 & 8.385284 \\
\hline MRS-1 & RS - 1 & NRC & TPM & 23.83928 & \\
\hline $\mathrm{MTC}-3$ & $\mathrm{~T}-1$ & NRC & TPM & 25.85531 & \\
\hline $\begin{array}{l}\text { MRS - } 2 \\
0.1336482\end{array}$ & $\begin{array}{l}\text { RS }-1 \\
2-07\end{array}$ & NRC & TPM & 0.3525678 & 23.86689 \\
\hline $\begin{array}{c}\text { MRS - } 2 \\
17.90016\end{array}$ & RS-2 & NRC & TPM & 0.3525673 & 23.86689 \\
\hline $\begin{array}{l}\text { MRS-3 } \\
17.90017\end{array}$ & RS- 2 & NRC & TPM & 2.712735 & 1.834662 \\
\hline $\begin{array}{c}\text { MRS - } 3 \\
8.074433\end{array}$ & RS- 3 & NRC & TPM & 2.712735 & 1.834662 \\
\hline $\begin{array}{c}\text { MRS-4 } \\
8.074436\end{array}$ & RS- 3 & NRC & TPM & 6.897895 & 1.122834 \\
\hline $\begin{array}{l}\text { MRS-4 } \\
3.189288\end{array}$ & RS- 4 & NRC & TPM & 6.897895 & 1.122834 \\
\hline $\begin{array}{l}\text { MRS-5 } \\
\text { 3. } 189292\end{array}$ & RS- 4 & NRC & TPM & 11.05436 & 1.511232 \\
\hline $\begin{array}{l}\text { MRS-5 } \\
12.33987\end{array}$ & RS-5 & NRC & TPM & 11.05436 & 1.511232 \\
\hline $\begin{array}{c}\text { MRS-6 } \\
12.33987\end{array}$ & RS - 5 & NRC & TPM & 15.20985 & 0.4680283 \\
\hline $\begin{array}{l}\text { MRS - } 6 \\
10.94133\end{array}$ & RS- 6 & NRC & TPM & 15.20985 & 0.4680283 \\
\hline
\end{tabular}


Attachment B: REDOX (Original "GT Strud!" Model) Output for Seismic Analysis (Using Original Ground Response Spectrum for 10\% Damping)

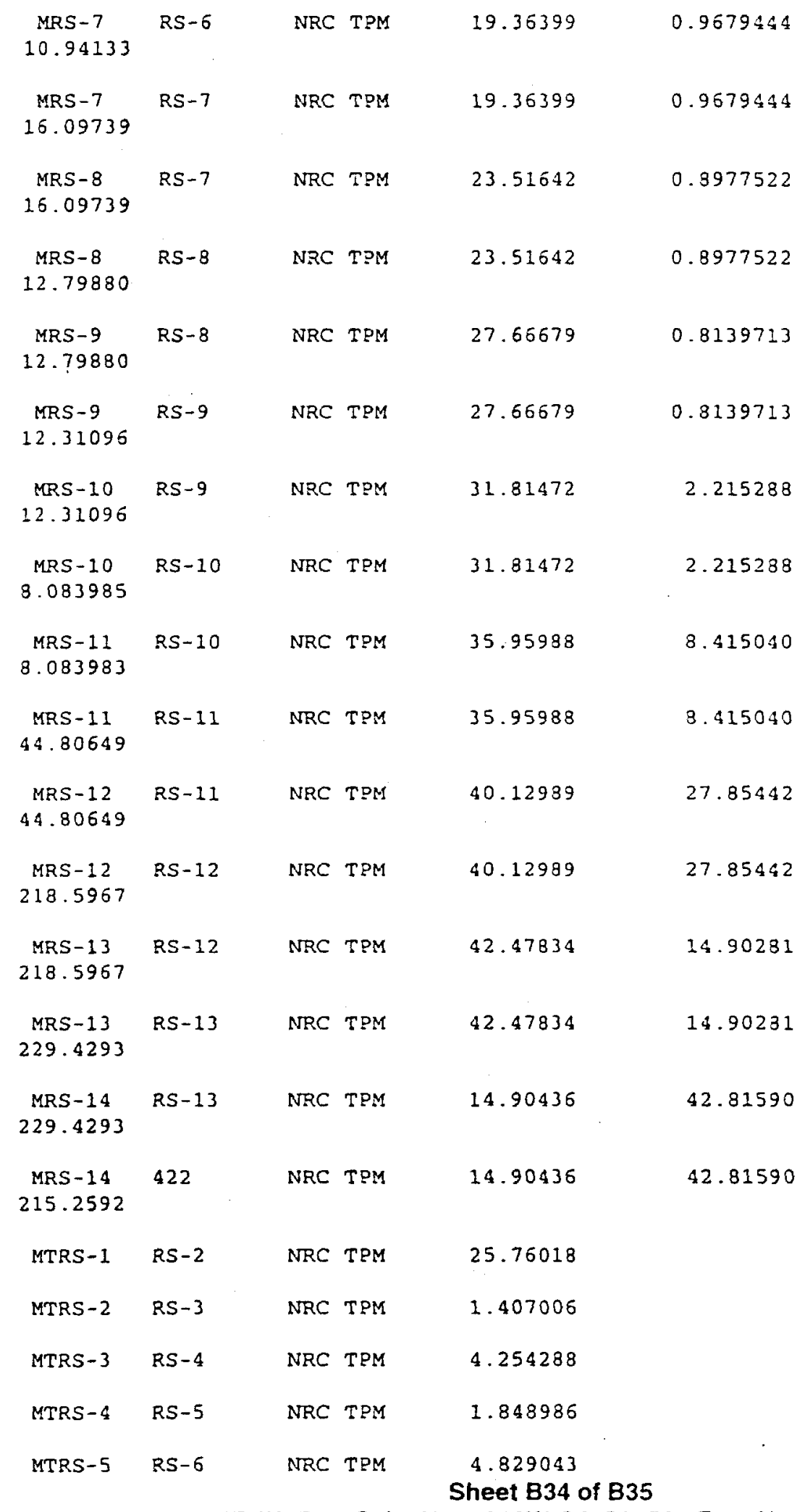

ATTTACHMENT-B: Calc. No. 0200W-CA-C0156 Rev. No. 0 Job No. 22192 
Attachment B: REDOX (Original "GT Strudl" Model) Output for Seismic Analysis (Using Original Ground Response Spectrum for 10\% Damping)

$\begin{array}{llll}\text { MTRS-6 } & \text { RS-7 } & \text { NRC TPM } & 2.670503 \\ \text { MTRS-7 } & \text { RS-8 } & \text { NRC TPM } & 4.816037 \\ \text { MTRS-8 } & \text { RS-9 } & \text { NRC TPM } & 1.892192 \\ \text { MTRS-9 } & \text { RS-10 } & \text { NRC TPM } & 11.43211 \\ \text { MTRS-10 } & \text { RS-11 } & \text { NRC TPM } & 20.11436 \\ \text { MTRS-11 } & \text { RS-12 } & \text { NRC TPM } & 13.77236 \\ (455)> & & \\ \{456)> & & \\ (457\}> & & \\ (458)> & \end{array}$


BHI-01299

Rev. 0

$\therefore$ 
BHI-01299

Rev. 0

ATTACHMENT:

C

ORIGINATOR:

R. S. Rajagopal

Bt

DATE: August 19,1999

CHECKED BY:

C. A. Palmquist

CALC. NO. 0200W-CA-C0156

DATE:

$3<0<1<3$

SHEET NO. C1 OF TOTAL 10 REV. NO. 0 SHEETS

\section{ATTACHMENT " $\mathrm{C}$ "}

REDOX (Corrected Coordinates in "GT Strudl" Model) Input for Seismic Analysis (Using Original Ground Response Spectrum for 10\% Damping) 
Attachment C: REDOX (Corrected Coordinates in "GT Strudl" Model) Input for Seismic Analysis (Using Original Ground Response Spectrum for $10 \%$ Damping)

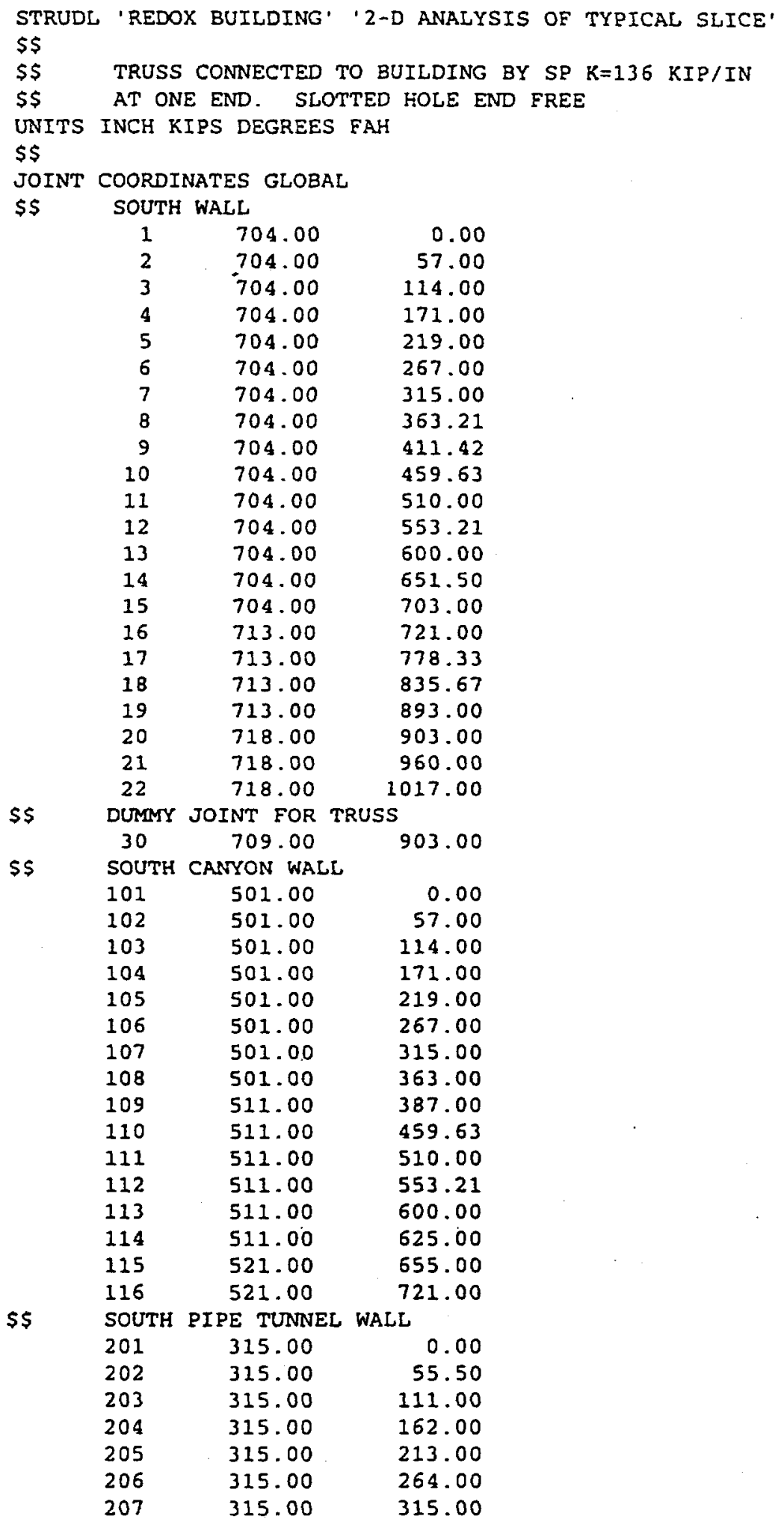

Sheet $\mathrm{C} 2$ of $\mathrm{C} 10$

ATTTACHMENT-C: Calc. No. 0200W-CA-C0156 Rev. No. 0 Job No. 22192 
Attachment C: REDOX (Corrected Coordinates in "GT Strudl" Model) Input for SeV 0 (Using Original Ground Response Spectrum for 10\% Damping)

\begin{tabular}{|c|c|c|c|}
\hline & 208 & 267.00 & 363.00 \\
\hline \multirow{9}{*}{$\$ \$$} & NORTH & PIPE TUNNEL & WALL \\
\hline & 301 & 183.00 & 0.00 \\
\hline & 302 & 183.00 & 55.50 \\
\hline & 303 & 183.00 & 111.00 \\
\hline & 304 & 183.00 & 162.00 \\
\hline & 305 & 183.00 & 213.00 \\
\hline & 306 & 183.00 & 264.00 \\
\hline & 307 & 183.00 & 315.00 \\
\hline & 308 & 231.00 & 363.00 \\
\hline \multirow[t]{22}{*}{$\$ \$$} & NORTH & CANYON WALL & \\
\hline & 401 & 0.00 & 0.00 \\
\hline & 402 & 0.00 & 57.00 \\
\hline & 403 & 0.00 & 114.00 \\
\hline & 404 & 0.00 & 171.00 \\
\hline & 405 & 0.00 & 219.00 \\
\hline & 406 & 0.00 & 267.00 \\
\hline & 407 & 0.00 & 315.00 \\
\hline & 408 & 0.00 & 363.00 \\
\hline & 409 & -28.00 & 403.00 \\
\hline & 410 & -28.00 & 459.00 \\
\hline & 411 & -28.00 & 513.75 \\
\hline & 412 & -28.00 & 568.50 \\
\hline & 413 & -28.00 & 623.25 \\
\hline & 414 & -28.00 & 678.00 \\
\hline & 415 & -28.00 & 703.00 \\
\hline & 416 & -37.00 & 721.00 \\
\hline & 417 & -37.00 & 778.00 \\
\hline & 418 & -37.00 & 835.67 \\
\hline & 419 & -37.00 & 893.00 \\
\hline & 420 & -42.00 & 903.00 \\
\hline & 421 & -42.00 & 960.00 \\
\hline
\end{tabular}

$\$ \$$ DUMYY JOINT FOR TRUSS CONNECTION

$\$ \$$ NORTH GALLERY WALL

$502 \quad-274.00 \quad 57.25$

$503 \quad-274.00 \quad 114.13$

$504 \quad-274.00 \quad 171.00$

$505 \quad-274.00 \quad 219.00$

$506 \quad-274.00 \quad 267.00$

$507 \quad-274.00 \quad 315.00$

$508 \quad-274.00 \quad 363.00$

$509 \quad-274.00 \quad 411.00$

$510 \quad-274.00 \quad 459.00$

$511 \quad-274.00 \quad 513.75$

$512 \quad-274.00 \quad 568.50$

$513 \quad-274.00 \quad 623.25$

$514 \quad-274.00 \quad 678.00$

$\$ \$$ SLAB $\$ 1$ SOUTH GALLERY

$\begin{array}{lll}\text { S } 1-1 ' \quad 568.67 & 171.00\end{array}$

. S1-2' $636.33 \quad 171.00$

\$\$ SLAB S2 \& SOUTH GALLERY

. $52-1 . \quad 568.67 \quad 315.00$

' $52-2$ ' $636.33 \quad 315.00$

$\$ 5$ SLAB $S 3$ SOUTH GALLERY

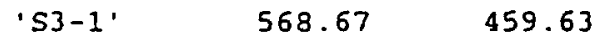

Sheet $\mathrm{C} 3$ of $\mathrm{C} 10$

ATTTACHMENT-C: Calc. No. 0200W-CA-C0156 Rev. No. 0 Job No. 22192 
BHI-01299

Rev. 0

Attachment C: REDOX (Corrected Coordinates in “GT Strudl” Model) Input for Seismic Analysis (Using Original Ground Pesponse Spectrum for 10\% Damping)

\begin{tabular}{|c|c|c|c|}
\hline \multicolumn{2}{|l|}{ 's3-2' } & 636.33 & 459.63 \\
\hline SLAB & 54 & e SOUTH & GALLERY \\
\hline 'S4-1' & & 568.67 & 600.00 \\
\hline$' 54-2$ ' & & 636.33 & 600.00 \\
\hline SLAB & s5 & E NORTH & GALLERY \\
\hline 's5-1' & & -9.1 .33 & 171.00 \\
\hline ' $S 5-2$ ' & & -182.67 & 171.00 \\
\hline SLAB & s6 & a NORTH & GALLERY \\
\hline ' $\$ 6-1$ ' & & -91.33 & 315.00 \\
\hline 's6-2. & & -182.67 & 315.00 \\
\hline SLAB & 57 & e NORTH & GALLERY \\
\hline ' $57-1$ ' & & -91.33 & 459.00 \\
\hline$' 57-2$ ' & & -182.67 & 459.00 \\
\hline SLAB & s8 & e NORTH & GALLERY \\
\hline 's8-1' & & -91.33 & 678.00 \\
\hline ' $58-2$ ' & & -182.67 & 678.00 \\
\hline SLAB & s9 & Q PIPE T & UNNEL \\
\hline ' $59-1$ ' & & 249.00 & 111.00 \\
\hline ROOF & TRU & JSS BOTTON & M CHORD \\
\hline$\cdot T-1$. & & 709.00 & 909.50 \\
\hline$\cdot \mathrm{T}-2$. & & 634.00 & 909.50 \\
\hline$\cdot \mathrm{T}-3$. & & 486.00 & 909.50 \\
\hline$' T-4$ ' & & 338.00 & 909.50 \\
\hline$\cdot T-5$ ' & & 190.00 & 909.50 \\
\hline$\cdot T-6^{\circ}$ & & 42.00 & 909.50 \\
\hline$\cdot \mathrm{T}-7$ ' & & -33.00 & 909.50 \\
\hline$\cdot T-8 \cdot$ & & 709.00 & 1003.50 \\
\hline ' $T-9^{\prime}$ & & 634.00 & 1003.50 \\
\hline$\cdot T-10^{\prime}$ & & 560.00 & 1003.50 \\
\hline ' $T-11$ ' & & 486.00 & 1003.50 \\
\hline ' $\mathrm{T}-12$ ' & & 412.00 & 1003.50 \\
\hline$\cdot \mathrm{T}-13^{\prime}$ & & 338.00 & 1003.50 \\
\hline${ }^{\prime} \mathrm{T}-14^{\circ}$ & & 264.00 & 1003.50 \\
\hline$\cdot T-15^{\prime}$ & & 190.00 & 1003.50 \\
\hline ' $\mathrm{T}-16^{\prime}$ & & 116.00 & 1003.50 \\
\hline ' $T-17^{\prime}$ & & 42.00 & 1003.50 \\
\hline$\cdot T-18^{\prime}$ & & -33.00 & 1003.50 \\
\hline ROOF & SLA. & & \\
\hline 'RS-1' & & 718.00 & 1021.00 \\
\hline ' RS-2. & & 709.00 & 1021.00 \\
\hline 'RS-3' & & 634.00 & 1021.00 \\
\hline 'RS-4' & & 550.00 & 1021.00 \\
\hline 'RS-5' & & 486.00 & 1021.00 \\
\hline 'RS-6' & & 412.00 & 1021.00 \\
\hline 'RS-7' & & 338.00 & 1021.00 \\
\hline 'RS-8' & & 264.00 & 1021.00 \\
\hline 'RS-9' & & 190.00 & 1021.00 \\
\hline 'RS-10' & & 116.00 & 1021.00 \\
\hline 'RS-11' & & 42.00 & 1021.00 \\
\hline 'RS-12' & & -33.00 & 1021.00 \\
\hline 'RS-13' & & -42.00 & 1021.00 \\
\hline
\end{tabular}

TYPE PLANE FRAME

\$\$ MEMBER FOR SOUTH GALLERY WALL MEMBER INCIDENCES
1
1
2

GENERATE 20 MEMBERS ID 2 EROM 2 INC 1 TO 3 INC 1

ATTTACHMENT-C: Calc. No. $0200 W-C A-C 0156$ Rev. No. 0 Job No. 22192 
Attachment C: REDOX (Corrected Coordinates in "GT Strudl" Model) Imput for Rev. 0 (Using Original Ground Response Spectrum for 10\% Damping)

\$\$ MEMBER FOR SOUTH CANYON WALL

MEMBER INCIDENCES

$101 \quad 101 \quad 102$

GENERATE 14 MEMBERS ID 102 FROM 102 INC 1 TO 103 INC 1

$\$ \$$ MEMBER FOR SOUTH PIPE TUNNEL WALL

MEMBER INCIDENCES

$201201-202$

GENERATE 6 MEMBERS ID 202 FROM 202 INC 1 TO 203 INC 1

$\$ \$$ MEMBER FOR NORTH PIPE TUNNEL WALL

MEMBER INCIDENCES

$301 \quad 301 \quad 302$

GENERATE 6 MEMBERS ID 302 FROM 302 INC 1 TO 303 INC 1

\$\$ MEMBER FOR NORTH CANYON WALL

MEMBER INCIDENCES

$401 \quad 401 \quad 402$

GENERATE 20 MEMBERS ID 402 FROM 402 INC 1 TO 403 INC 1

\$\$ MEMBER FOR NORTH GALLERY WALL

MEMBER INCIDENCES

$502 \quad 502 \quad 503$

GENERATE 11 MEMBERS ID 503 FROM 503 INC 1 TO 504 INC 1

MEMBER INCIDENCES

\$\$ SLAB $88^{\circ}$ SOUTH GALLERY

'MS1-1' 104 'S1-1'

'MS1-2' 's1-1' 's1-2'

'MS1-3' 'SI-2' 4

$\$ \$$ SLAB $9100^{\circ}$ SOUTH GALLERY 'MS2-1. 107 . S2-1'

'MS2-2' 'S2-1' $S 2-2$ '

'MS2-3' 'S2-2' 7

$\$ \$$ SLAB $112^{\prime} 11^{\prime}$ " SOUTH GALLERY

'MS3-1' 110 'S3-1'

'MS3-2' 'S3-1', $53-2$ '

MS3-3' $53-2$ ' 10

$\$ \$$ SLAB $124^{\circ}$ SOUTH GALLERY

'MS4-1. 113 'S4-1.

'MS4-2' 'S4-1' 'S4-2'

'MS4-3' 'S4-2' 13

\$\$ SLAB $83^{\prime}$ NORTH GALLERY

'MS5-1' 404 'S5-1'

'MS5-2' 'S5-1' 'S5-2

'MS5-3' $55-2^{\prime}$. 504

\$\$ SLAB \& 100' NORTH GALLERY

MS6-1. 407 :S6-1.

'MS6-2. 'S6-1' 'S6-2'

'MS6-3' 'S6-2' 507

\$\$ SLAB 112' NORTH GALLERY

'MS7-1' 410 'S7-1.

'MS7-2' 'S7-1' $57-2$ '

'MS7-3' 'S7-2' 510

$\$ \$$ SLAB @ $130^{\circ} 6^{*}$ NORTH GALLERY

'MS8-1' 414 'S8-1'

MS8-2' 'S8-1' 'S8-2.

'MS8-3. 'S8-2. 514

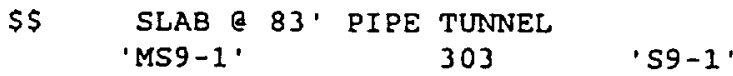

'MS9-2' 'S9-1' 203

$\$ \$$ PIPE TUNNEL ROOF \& $105^{\circ} 6^{\circ}$

ATTTACHMENT-C: Calc. No. 0200W-CA-C0156 Rev. No. 0 Job No. 22192 
BHI-01299

Rev. 0

Attachment C: REDOX (Corrected Coordinates in "GT Strud" Model) Input for Seismic Analysis (Using Original Ground Response Spectrum for $10 \%$ Damping)

\begin{tabular}{|c|c|c|c|c|}
\hline \multirow{3}{*}{\multicolumn{5}{|c|}{$\begin{array}{l}\text { 'MTR }-1 ' \\
\$ \$ \\
\text { TYPE PLANE TRUSS }\end{array}$}} \\
\hline & & & & \\
\hline & \multicolumn{4}{|c|}{ TYPE PLANE TRUSS } \\
\hline MEMBER & INCIDENCES & & & \\
\hline \multirow{3}{*}{$\$ \$$} & COVERS ON CELL & & & \\
\hline & ' $\mathrm{CC}-1$. & 208 & & 108 \\
\hline & $\cdot c c-2$ ' & 408 & & 308 \\
\hline & TRUSS MEMBERS & BOTTOM & CHORD & \\
\hline
\end{tabular}

GENERATE 5 MEMBERS ID 'MT-2. INC 1 FROM ' $T$-2' INC 1 TO ' $T$ - 3 ' INC 1

$\$ \$$ TRUSS MEMBERS TOP CHORD

MEMBER INCIDENCES

'MT-7. 'T-8' T 'T-9.

GENERATE 9 MEMBERS ID 'MT-8. INC 1 FROM 'T-9' INC 1 TO 'T-I0' INC 1

$\$ \$$ TRUSS MEMBERS DIAGONALS AND VERTICALS

MEMBER INCIDENCES

\begin{tabular}{|c|c|c|}
\hline ' $M T-17$ ' & ' $T-1$ ' & $\cdot T-8$ ' \\
\hline ' MT-18' & ' $\mathrm{T}-2$ ' & $' T-8$ ' \\
\hline 'MT-19' & $\cdot T-2$. & 'T-9. \\
\hline ' $\mathrm{MT}-20^{\circ}$ & $\cdot \mathrm{T}-2^{\prime}$ & $\mathrm{T}-10^{\circ}$ \\
\hline ' $M T-21$ & $' \mathrm{~T}-3$ ' & 'T-10' \\
\hline ' $M T-22^{\prime}$ & $T-3$. & 'T-11' \\
\hline$\cdot \mathrm{MT}-23^{\prime}$ & ' $\mathrm{T}-3$ ' & $\cdot \mathrm{T}-12$ ' \\
\hline ' $M T-2 \mathrm{~S}^{\prime}$ & $\cdot T-4$. & $\cdot T-12$ ' \\
\hline 'MT-25' & ' $T-4$ ' & $\cdot \mathrm{T}-13^{\circ}$ \\
\hline ' $M T-26^{\circ}$ & ' $T-4$ ' & ' $\mathrm{T}-14^{\prime}$ \\
\hline ' $M T-27^{\prime}$ & $\cdot \mathrm{T}-\mathrm{S}^{\prime}$ & $\cdot T-14^{\prime}$ \\
\hline ' MT-28' & $\cdot \mathrm{T}-5^{\circ}$ & $\cdot T-15^{\prime}$ \\
\hline ' $M T-29 \cdot$ & $\cdot \mathrm{T}-5^{\circ}$ & $\cdot T-16^{\circ}$ \\
\hline ' $M T-30^{\circ}$ & $' T-6$ ' & $\cdot \mathrm{T}-16^{\prime}$ \\
\hline $\mathrm{MT}-31$ & ' $\mathrm{T}-6^{\prime}$ & $=T-17^{\prime}$ \\
\hline$M T-32$ & $\cdot \mathrm{T}-6^{\circ}$ & $\cdot \mathrm{T}-18^{\circ}$ \\
\hline$M T-33^{\prime}$ & $\cdot \mathrm{T}-7$ ' & ' $\mathrm{T}-18^{\prime}$ \\
\hline
\end{tabular}

$\$ \$$

TYPE PLANE FRAME

MEMBER INCIDENCES

\$\$ CONNECTION TO BUILDING STRUCTURE SOUTH SIDE

'MTC-1' $19 \quad 30$

'MTC-2' $20 \quad 30$

\$\$ 'MTC-3' MODALLED AS TRUSS MEM - NO LATERAL TRANSFER

\$S CONNECTION TO BUILIDING STRUCTURE NORTH SIDE

'MTC-11' $419 \quad 430$

'MTC-12' $420 \quad 430$

'MTC-13' $430 \quad \mathrm{~T}-7$ '

$\$ \$$

TYPE PLANE TRUSS

MEMBER INCIDENCES

$\$ \$$ ROOF SLAB MEMBER

'MRS-1' 22 'RS-1'

\$\$ CONNECTION BETWEEN TRUSS AND BUILDING - AXIAL LOAD ONLY

$\$ \$$ 'MTC-3' 30 'T-1'

TYPE PLANE FRAME

MEMBER INCIDENCES

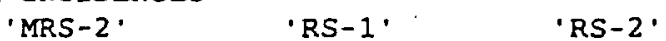

GENERATE 11 MEMBERS ID 'MRS-3' INC 1 FROM 'RS-2' INC 1 TO 'RS-3' INC 1 MEMBER INCIDENCES

ATTTACHMENT-C: Calc. No. $0200 W-C A-C 0156$ Rev. No. 0 Job No. 22192 
Attachment C: REDOX (Corrected Coordinates in "GT Strudl" Model) Input for Seismic Analysis (Using Original Ground Response Spectrum for 10\% Damping)

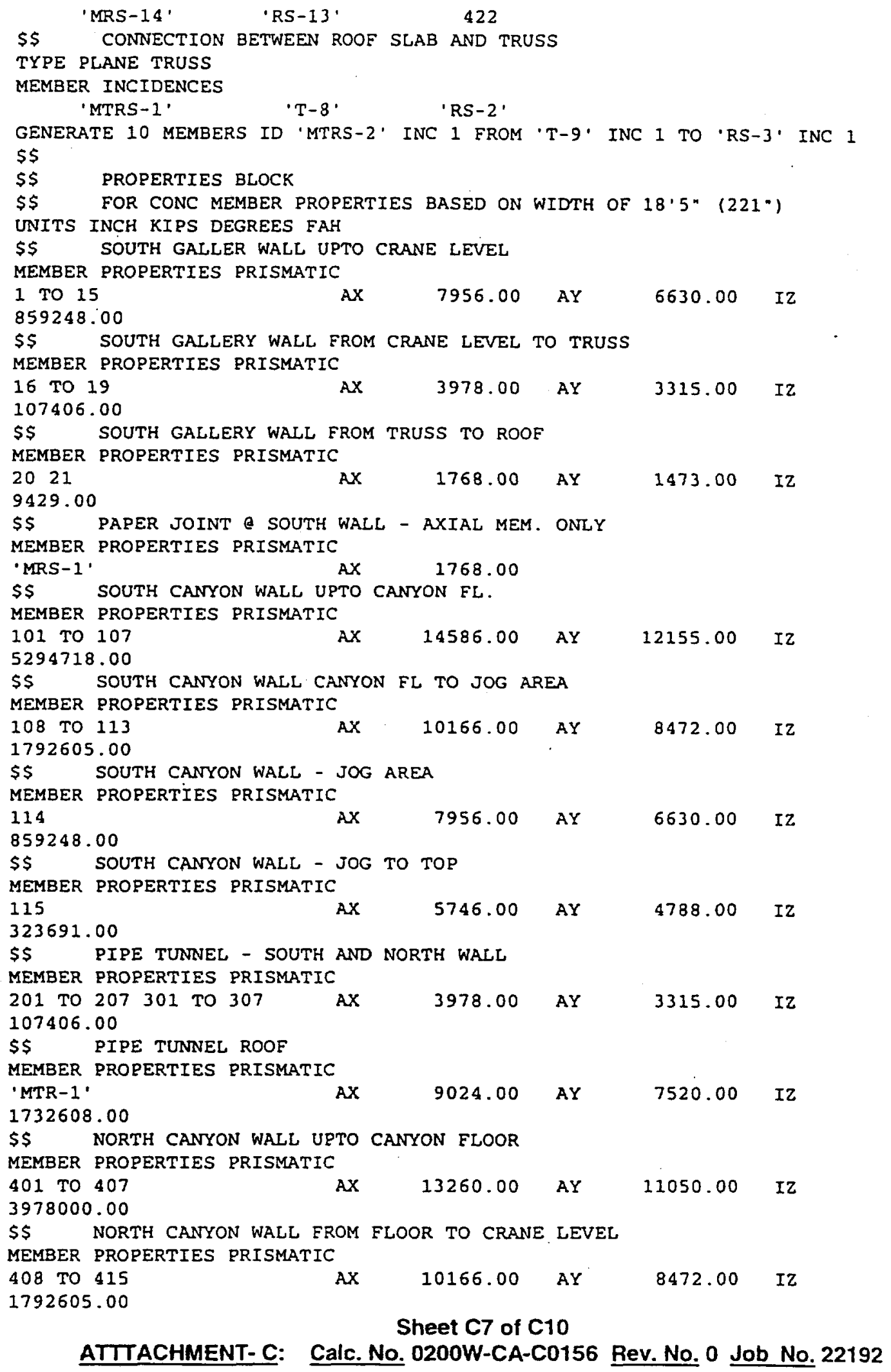

ATTTACHMENT-C: Calc. No. $0200 W-C A-C 0156$ Rev. No. 0 Job No. 22192 
BHI-01299

Rev. 0

Attachment C: REDOX (Corrected Coordinates in "GT Strudl" Model) Input for Seismic Analysis (Using Original Ground Response Spectrum for 10\% Damping)

\$\$ NORTH CANYON WALL EROM CRANE LEVEL TO TRUSS SUPPORT

MEMBER PROPERTIES PRISMATIC

$\begin{array}{lllllll}416 & \text { TO } 419 & \text { AX } & 3978.00 & \text { AY } & 3315.00 & \text { IZ }\end{array}$

107406.00

\$\$ NORTH CANYON WALL FROM TRUSS SUPPORT TO ROOF

MEMBER PROPERTIES PRISMATIC

$\begin{array}{llllll}420421 & \text { AX } & 1768.00 & \text { AY } & 1473.00 & \text { IZ } \\ 9429.00 & & & & & \\ 5 \$ & \text { NORTH GALLERY WALL } & & & & \\ \text { MEMBER PROPERTIES PRISMATIC } & \text { AX } & 5304.00 & \text { AY } & 4420.00 & \text { IZ }\end{array}$

95472.00

\$\$ I' THICK SLAB

MEMBER PROPERTIES PRISMATIC

'MS1-1' TO 'MS1-3' 'MS2-1' TO 'MS2-3' 'MS3-1' TO 'MS3-3' -

'MS5-1' TO 'MS5-3' 'MS6-1' TO 'MS6-3' 'MS7-1' TO 'MS7-3' -

'MS9-1' TO 'MS9-2' AX 2652.00 AY 2210.00 IZ

31824.00

$\$ \$ \quad 1 \cdot 6 \cdot$ THICK SLAB

MEMBER PROPERTIES PRISMATIC

'MS4-1' TO 'MS4-3' 'MS8-1' TO 'MS8-3' -

107406.00

AX $\quad 3978.00 \quad$ AY $\quad 3315.00 \quad$ IZ

$\$ \$$ ROOF SLAB

MEMBER PROPERTIES PRISMATIC

'MRS-2. TO ${ }^{\circ}$ MRS-13 $3^{\circ}$ AX 1989.00 AY 1658.00 IZ

13425.00

$\$ \$$ TRUSS CONNECTION TO STRUCTURE

MEMBER PROPERTIES PRISMATIC

'MTC-1' TO 'MTC-2' 'MTC-11' TO 'MTC-12' -

859248.00

AX 7956.00 AY $6630.00^{\circ} \mathrm{IZ}$

$\$ \$$ REDUCED STIFFNESS FOR CONNECTION TO TRUSS

MEMBER PROPERTIES PRISMATIC

$\begin{array}{llllll}. M T C-13^{\circ} & \text { AX } & 7956.00 & \text { AY } & 0.50 & \text { IZ }\end{array}$

859248.00

$\$ \$$ COVER FOR CELLS

MEMBER PROPERTIES PRISMATIC

' $\mathrm{CC}-1$ ' 'CC-2' AX 10608.00

$\$ \$$ CONN BET TRUSS \& BLDG - TRUSS MEM \& SOUTH END

MEMBER PROPERTIES PRISMATIC

'MTC-3'

AX $\quad 7956.00$

$\$ \$$ TRUSS MEMBER

MEMBER PROPERTIES PRISMATIC

'MT-1' TO 'MT-16' AX

MEMBER PROPERTIES PRISMATIC

'MT-17' 'MT-33' AX

MEMBER PROPERTIES PRISMATIC

'MT-19' 'MT-31' AX

MEMBER PROPERTIES PRISMATIC

'MT-22' 'MT-28' AX

MEMBER PROPERTIES PRISMATIC

'MT-25' AX

MEMBER PROPERTIES PRISMATIC

'MT-18' 'MT-32' AX

MEMBER PROPERTIES PRISMATIC

'MT-20' 'MT-30'

Ax 6.62

Sheet $\mathrm{C} 8$ of $\mathrm{C10}$

ATTTACHMENT-C: Calc. No. 0200W-CA-C0156 Rev. No. 0 Job No. 22192 
BHI-01299

Rev. 0

Attachment C: REDOX (Corrected Coordinates in "GT Strudl" Model) Input for Selsmic Analysis (Using Original Ground Response Spectrum for $10 \%$ Damping)

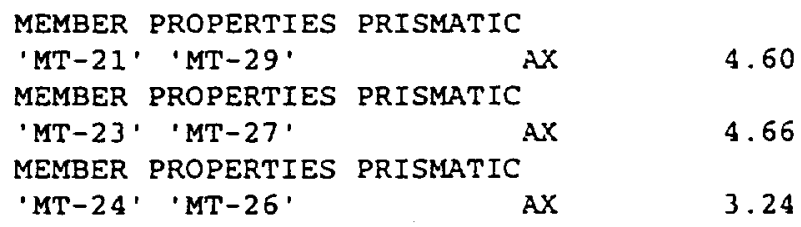

\$\$ CONNECTION BETWEEN TRUSS AND ROOF SLAB

MEMBER PROPERTIES PRISMATIC

'MTRS-1' TO 'MTRS-10' AX 2.00

$\$ \$$ REDUCE CONNECTION STIFFNESS FOR LAST PURLIN

MEMBER PROPERTIES PRISMATIC

'MTRS-11' AX 0.50

$\$ \$$

\$\$ SUPPORT LOCATIONS

$\$ \$$

STATUS SUPPORT JOINTS -

$\begin{array}{llllll}1 & 101 & 201 & 301 & 401 & 502\end{array}$

$\$ \$$

$\$ \$$ MATERIAL PROPERTIES

$\$ \$$

UNITS INCH LB DEG FAH

CONSTANTS

$\begin{array}{lll}E & 3.824 E+06 & \text { ALL } \\ G & 1.634 E+06 & \text { ALL } \\ \text { POI } & 1.700 E-01 & \text { ALL } \\ \text { DEN } & 8.680 E-02 & \text { ALL }\end{array}$

$\$ \$$

$\$ \$$

PROVIDE E, G, POT, DEN FOR STEEL MEMBERS

$\$ \$$

E 2.900E+07 'MT-1' TO 'MT-33' 'MTRS-1' TO 'MTRS-11'

G $1.115 E+07$ 'MT-1' TO 'MT-33' 'MTRS-1' TO 'MTRS-11.

POI 3.000E-01 'MT-1' TO 'MT-33' 'MTRS-1' TO 'MTRS-11'

DEN 2.B36E-01 'MT-1' TO 'MT-33' 'MTRS-1' TO 'MTRS-11'

$\$ \$$

$\$ \$$

ADJUST DENSITY OF ROOF SLAB TO ACCOUNT FOR FINISHES ETC.

$\$ \$$

DEN $1.003 \mathrm{E}-01$ 'MRS-1. TO 'MRS-13'

LUMPED WEIGHT OF STRUCTURE AT JOINTS

\$\$

$\$ \$$

INERTIA OF JOINTS LUMPED

UNIT CYCLES

EIGENPROBLEM PARAMETERS

SOLVE USING GTLANCZOS

FREQUENCY SPE 0.0 TO 33.0

END

PERFORM ASSEMBLY FOR DYNAMICS

PERFORM EIGENVALUE ANALYSIS

\$\$ LIST DYNAMIC MASS SUMMARY

UNIT INCH KIPS

LIST DYNAMIC MASS

LIST DYNAMIC PARTICPATION FACTORS

$\$ \$$

UNITS FEET SECONDS

DELETE RESPONSE SPECTRA 'RSH'

STORE RESPONSE SPECTRA ACCELERATION LOG VS FREQUENCY LOG 'RSH'

DAMPING 0.10 FACTOR 32.2

ATITACHMENT-C: Calc. No. 0200W-CA-C0156 Rev. No. 0 Job No. 22192 
BHI-01299

Rev: 0

Attachment C: REDOX (Corrected Coordinates in "GT Strudl" Model) Input for Seismic Analysis (Using Original Ground Response Spectrum for 10\% Damping)

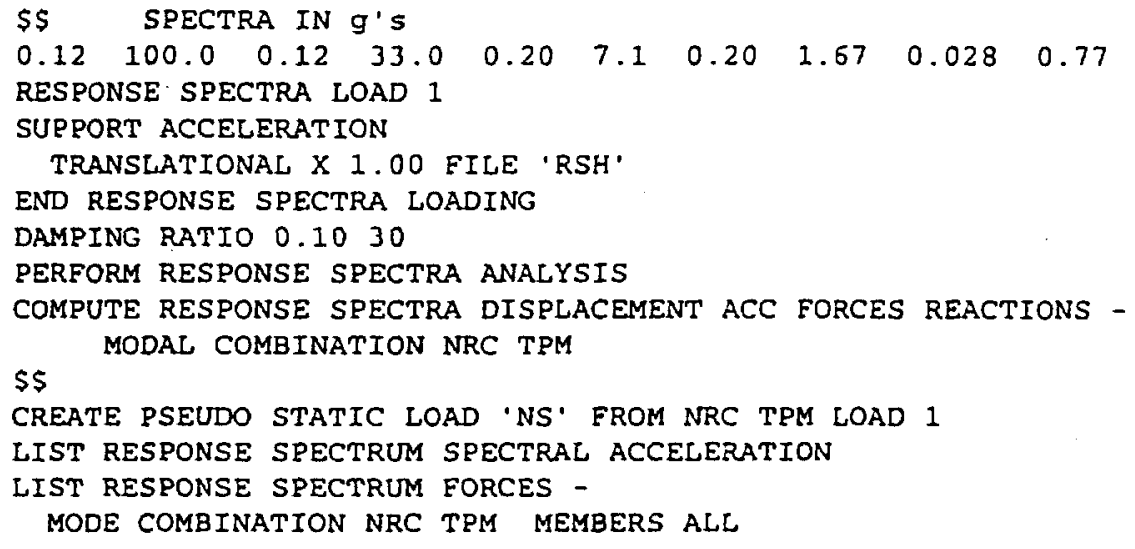


BHI-01299

Rev. 0

ATTACHMENT:

D

ORIGINATOR: R.S. Rajagopal 18 h

DATE: Auqust 19, 1999

CHECKED BY:

C. A. Palmquist ifre

DATE:

CALC. NO. O200W-CA-C0156

REV. NO.

0

SHEET NO. D1 OF TOTAL

35

SHEETS

\section{ATTACHMENT " $D$ "}

REDOX (Corrected Coordinates in "GT Strudl" Model) Output for Seismic Analysis (Using Original Ground Response Spectrum for 10\% Damping)

The governing output values used on sheet 13 are highlighted as " $\longleftarrow$ " in the following output. 
Attachment D: REDOX (Corrected Coordinates in "GT Strudl" Model) Output for Seismic Analysis (Using Original Ground Response Spectrum for 10\% Damping)

\section{Commercial Software Rights Legend}

Any use, duplication or disclosure of this software by or for the U.S. Government shall be restricted to the terms of a license agreement in accordance with the clause at DFARS $227.7202-3$

This computer software is an unpublished work containing valuable trade secrets owned by the Georgia Tech Research Corporation (GTRC). No access, use, transfer, duplication or disclosure thereof may be made except under a license agreement execuced by GTRC or its authorized representatives and no right, title or interest thereto is conveyed or granted herein, notwithstanding receipt or possession hereof. Decompilation of the object code is strictly prohibited.

Georgia Tech Research Corporation

Georgia Institute of Technology

Atlanta, Georgia 30332 U.S.A.

Copyright (C) 1998 GTRC

ALL RIGHTS RESERVED.

\#Wed Jul $21 \quad 12: 36: 41 \quad 1999$

1GTICES/C-NP 2.5.0 MD-NT 2.0. JanuarY 1995.

Proprietary to Georgia Tech Research Corporation, U.S.A.

Reading password file C: IProgram Files IGTSTRUDL 9801 Igtaccess.dat CI-w-audexist. Audit file FILE1236.aud already exists; select another file name.
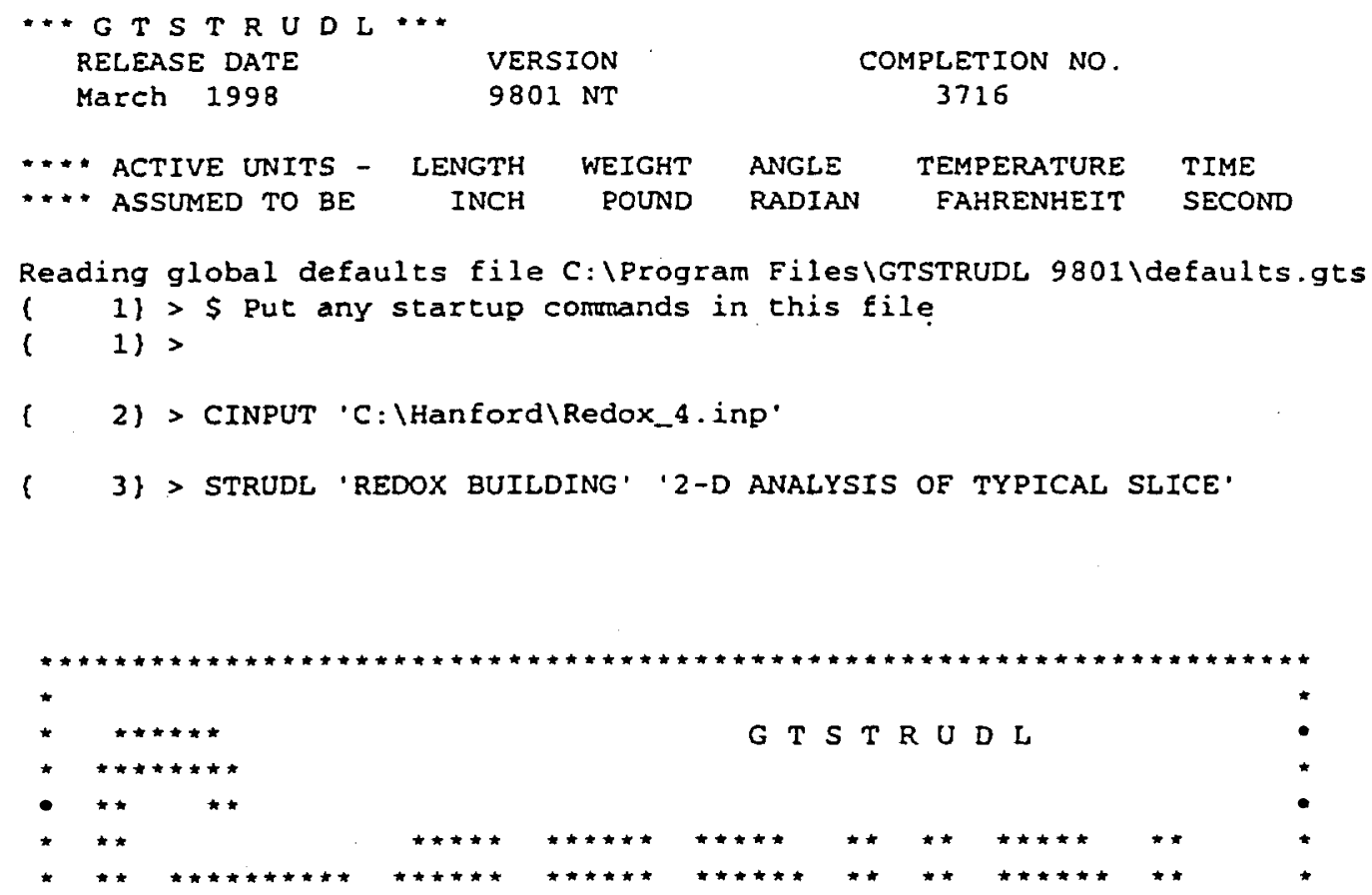

Sheet D2 of D35

ATTIACHMENT-D: Calc. No. 0200W-CA-C0156 Rev. No. 0 Job No. 22192 

(Using Original Ground Response Spectrum for 10\% Damping)
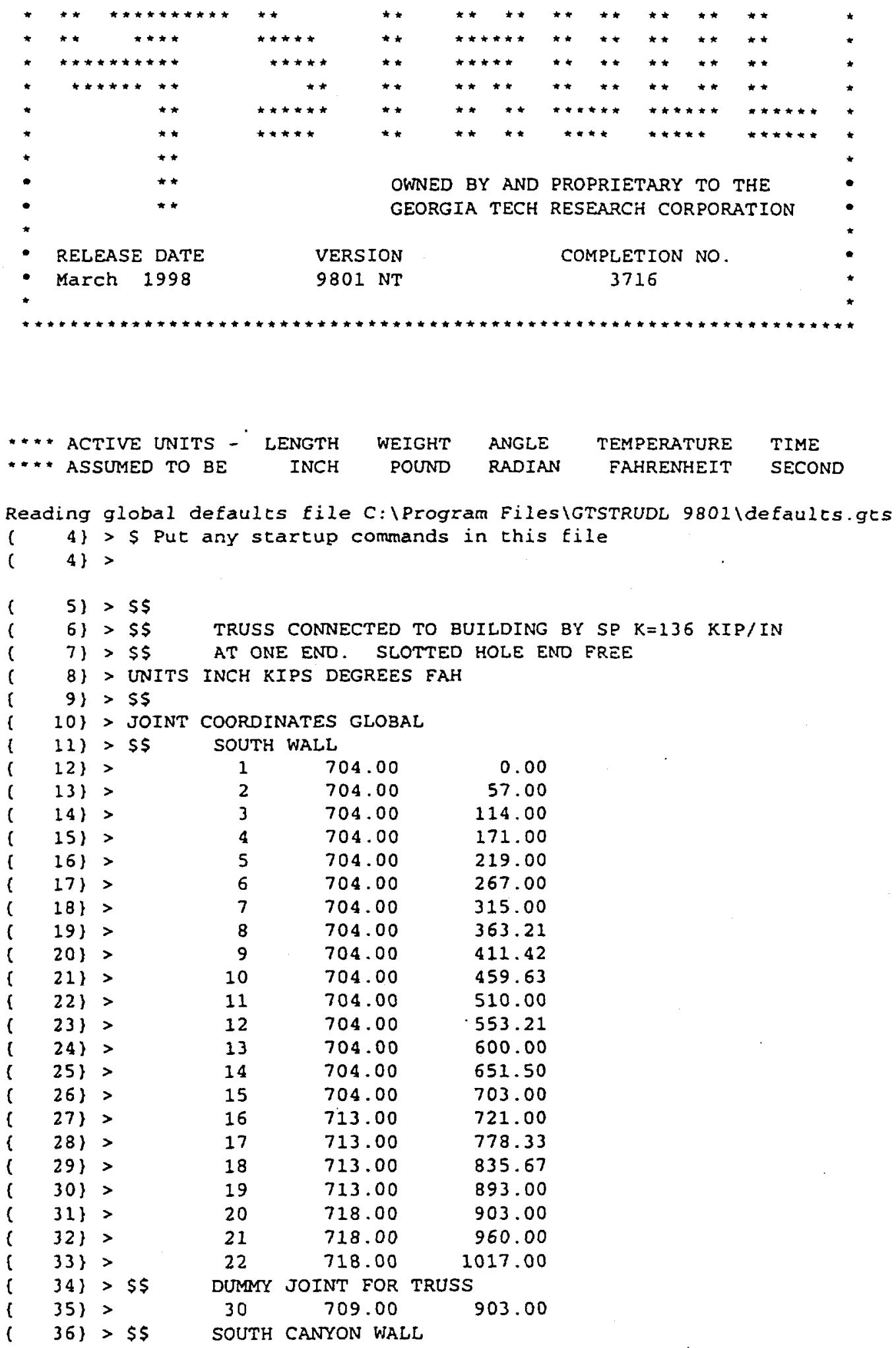

Sheet D3 of D35

ATTTACHMENT-D: Calc. No. 0200 W-CA-C0156 Rev. No. 0 Job No. 22192. 


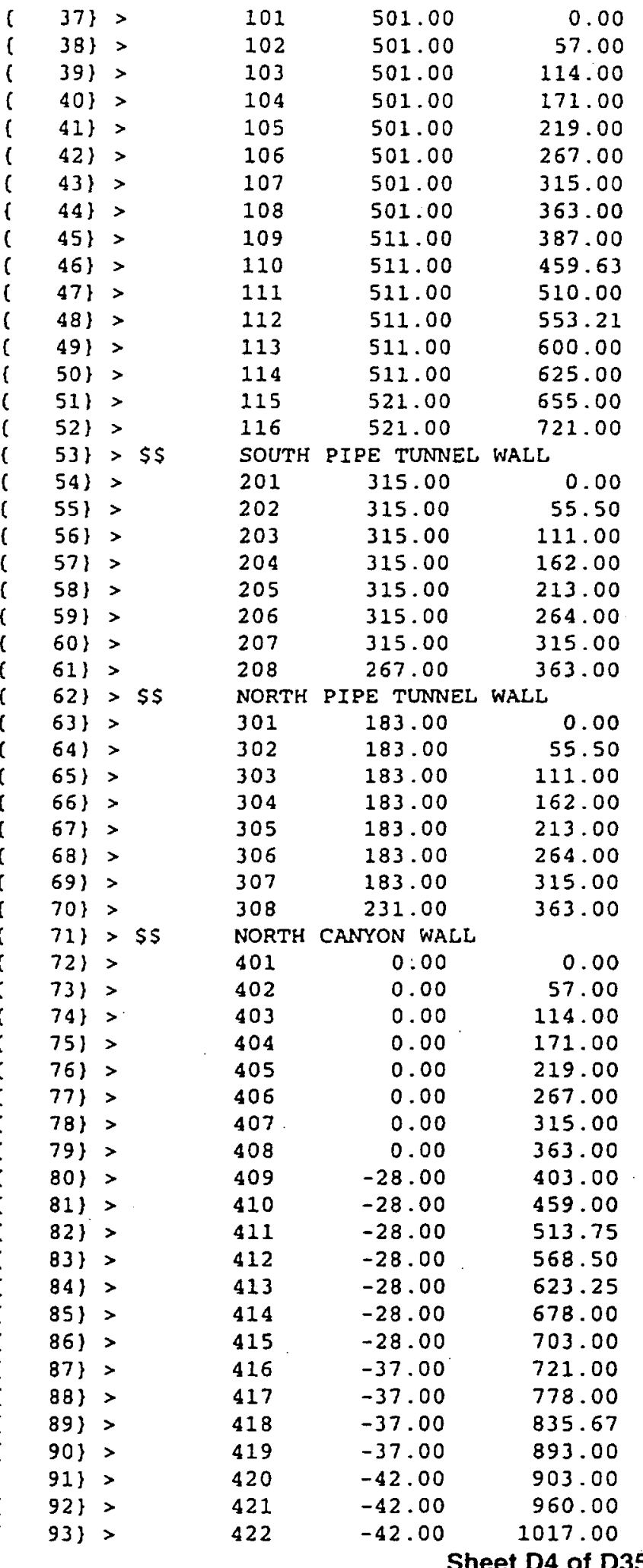

ATTTACHMENT-D: Calc. No. 0200W-CA-C0156 Rev. No. 0 Job No. 22192 


\begin{tabular}{|c|c|c|c|c|c|}
\hline 94$\}$ & \multicolumn{5}{|c|}{ DUMMY JOINT FOR TRUSS CONNECTION } \\
\hline 95\} & $>$ & & 430 & -33.00 & 903.00 \\
\hline 96$\}$ & $>$ & $\$ \$$ & NORTH & H GALLERY WAL & \\
\hline 97) & $>$ & & 502 & -274.00 & 57.25 \\
\hline 98$\}$ & $>$ & & 503. & -274.00 & 114.13 \\
\hline 991 & $>$ & & 504 & -274.00 & 171.00 \\
\hline 100$\}$ & $>$ & & 505 & -274.00 & 219.00 \\
\hline 101) & $>$ & & 506 & -274.00 & 267.00 \\
\hline 102$\}$ & $>$ & & 507 & -274.00 & 315.00 \\
\hline 103$\}$ & $>$ & & 508 & -274.00 & 363.00 \\
\hline 104$\}$ & $>$ & & 509 & -274.00 & 411.00 \\
\hline 105$\}$ & $>$ & & 510 & -274.00 & 459.00 \\
\hline 106) & $>$ & & 511 & -274.00 & 513.75 \\
\hline 107) & $>$ & & 512 & -274.00 & 568.50 \\
\hline 108$\}$ & $>$ & & 513 & -274.00 & 623.25 \\
\hline 109$\}$ & $>$ & & 514 & -274.00 & 678.00 \\
\hline $110 \mathrm{~b}$ & $>$ & $\$ \$$ & SLAB & SI SOUTH G: & ALLERY \\
\hline 111$\}$ & $>$ & & 's1-1' & 568.67 & 171.00 \\
\hline 112$\}$ & $>$ & & ' $S 1-2$ ' & 636.33 & 171.00 \\
\hline 113$\}$ & $>$ & \$\$ & SLAB S & S2 SOUTH GA & ALLERY \\
\hline 114$\}$ & $>$ & & 's2-1' & 568.67 & 315.00 \\
\hline 115) & $>$ & & $' 52-2$ ' & 636.33 & 315.00 \\
\hline 116$\}$ & $>$ & $\$ \$$ & SLAB & S3 e SOUTH GA & ALLERY \\
\hline 117$\}$ & $>$ & & 's3-1' & 568.67 & 459.63 \\
\hline 118$\}$ & $>$ & & 's3-2' & 636.33 & 459.63 \\
\hline 119$\}$ & $>$ & $\$ \$$ & SLAB & S4 a SOUTH GA & ALLERY \\
\hline 120$\}$ & $>$. & & $' 54-1$ ' & 568.67 & 600.00 \\
\hline 121$\}$ & $>$ & & 's4-2' & 636.33 & 600.00 \\
\hline 122$\}$ & $>$ & $\$ \$$ & SLAB & 55 \& NORTH GA & ALLERY \\
\hline 1231 & $>$ & & '55-1' & -91.33 & 171.00 \\
\hline 124$\}$ & $>$ & & 's5-2' & -182.67 & 171.00 \\
\hline 1251 & $>$ & $\$ \$$ & SLAB & S6 \& NORTH GA & ALLERY \\
\hline 1261 & $>$ & & 's6-1' & -91.33 & 315.00 \\
\hline 1271 & $>$ & & 's6-2' & -182.67 & 315.00 \\
\hline 128$\}$ & $>S$ & $\$ \$$ & SLAB & S7 \& NORTH GA & ALLERY \\
\hline 129\} & $>$ & & ' $57-1$ ' & -91.33 & 459.00 \\
\hline 1301 & $>$ & & 'S7-2' & -182.67 & 459.00 \\
\hline 131$\}$ & $>$ & $\$ \$$ & SLAB & S8 E NORTH GA & LLLERY \\
\hline 132$\}$ & $>$ & & ' S8-1' & -91.33 & 678.00 \\
\hline 133$\}$ & $>$ & & ' $58-2$ ' & -182.67 & 678.00 \\
\hline 134$\}$ & $>s$ & $\$ \$$ & SLAB & S9 a PIPE TUN & TNEL \\
\hline 135$\}$ & $>$ & & 's9-1' & 249.00 & 111.00 \\
\hline 136$\}$ & $>s$ & $\$ \$$ & ROOF ? & TRUSS BOTTOM & CHORD \\
\hline 137$\}$ & $>$ & & $\cdot \mathrm{T}-1 \cdot$ & 709.00 & 909.50 \\
\hline 138$\}$ & $>$ & & ' $\mathrm{T}-2$ ' & 634.00 & 909.50 \\
\hline 139\} & $>$ & & $\cdot \mathrm{T}-3$ ' & 486.00 & 909.50 \\
\hline 140$\}$ & $>$ & & ' $\mathrm{T}-\mathbf{4}^{\prime}$ & 338.00 & 909.50 \\
\hline 141) & $>$ & & ' $T-5$ ' & 190.00 & 909.50 \\
\hline 142$\}$ & $>$ & & 'T-6' & 42.00 & 909.50 \\
\hline 143$\}$ & $>$ & & $\cdot \mathrm{T}-7$ ' & -33.00 & 909.50 \\
\hline 144$\}$ & $>$ & & ' $\mathrm{T}-8$ ' & 709.00 & 1003.50 \\
\hline 145) & $>$ & & 'T-9' & 634.00 & 1003.50 \\
\hline 146$\}$ & $>$ & & $' \mathrm{~T}-10$ ' & 560.00 & 1003.50 \\
\hline 147$\}$ & $>$ & & $' T-11$ ' & 486.00 & 1003.50 \\
\hline 148$\}$ & $>$ & & 'T-12' & 412.00 & 1003.50 \\
\hline 149$\}$ & $>$ & & $. T-13$ ' & 338.00 & 1003.50 \\
\hline 150$\}$ & $>$ & & 'T-14' & 264.00 & 1003.50 \\
\hline
\end{tabular}

ATTTACHMENT-D: Calc. No. 0200W-CA-C0156 Rev. No. 0 Job No. 22192 


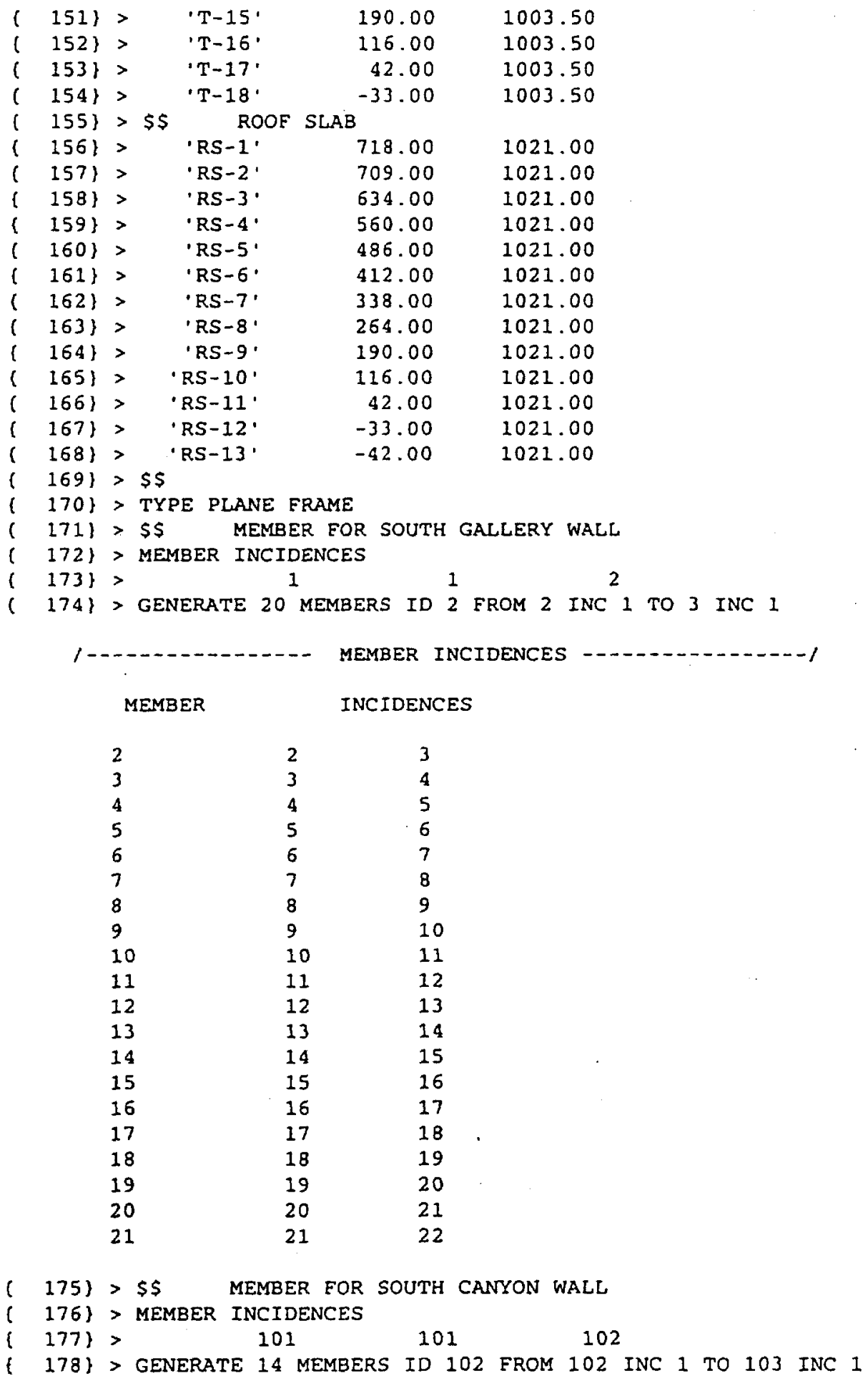

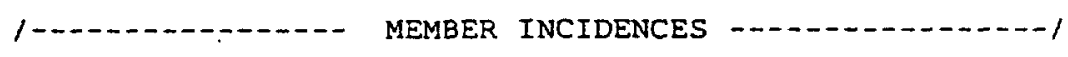


Attachment D: REDOX (Corrected Coordinates in "GT Strudl" Model) Output for Seismic Analysis (Using Original Ground Response Spectrum for $10 \%$ Damping)

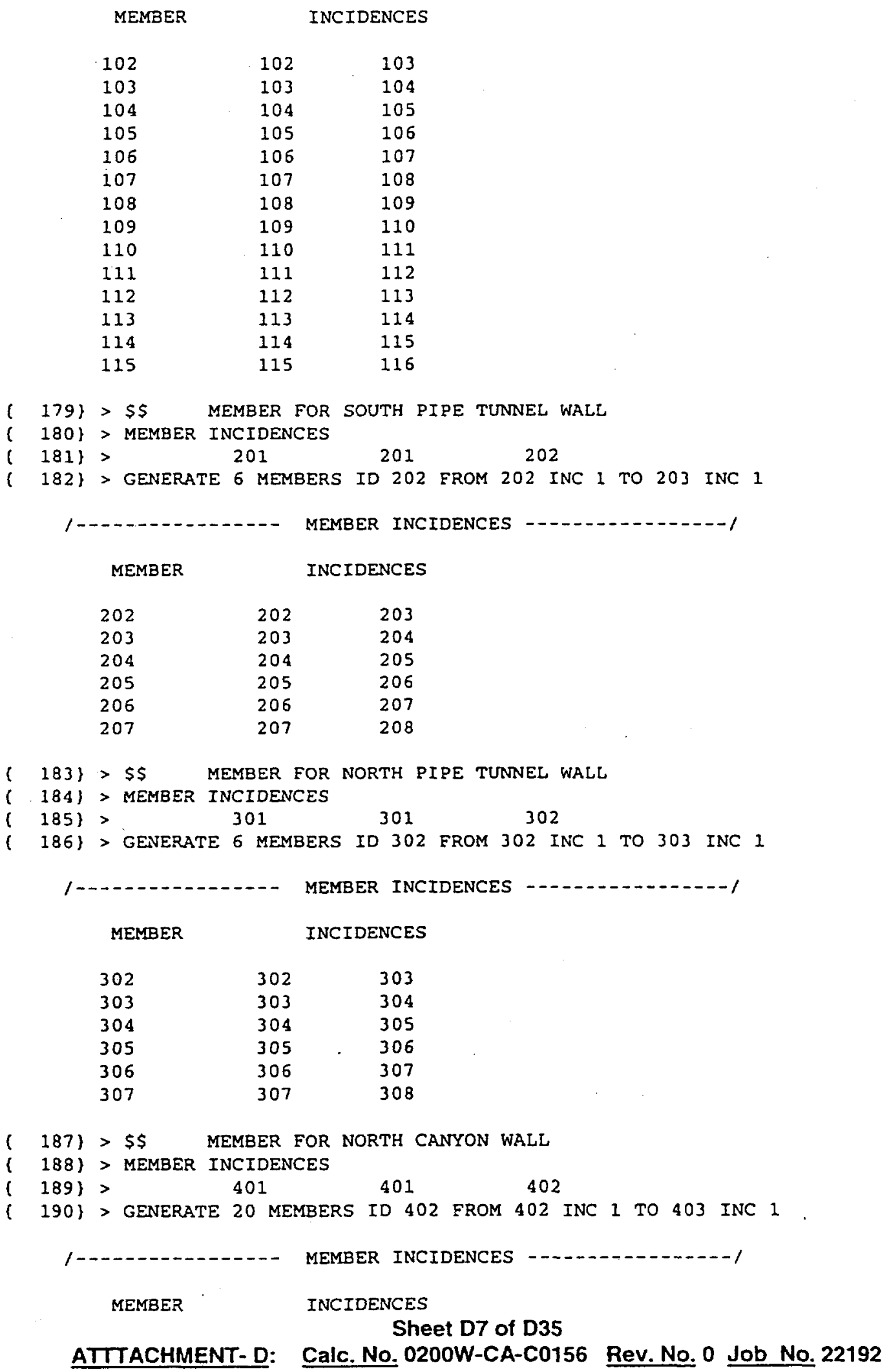


BHI-01299

Rev. 0

Attachment D: REDOX (Corrected Coordinates in "GT Strudl" Model) Output for Seismic Analysis (Using Original Ground Response Spectrum for 10\% Damping)

$\begin{array}{lll}402 & 402 & 403 \\ 403 & 403 & 404 \\ 404 & 404 & 405 \\ 405 & 405 & 406 \\ 406 & 406 & 407 \\ 407 & 407 & 408 \\ 408 & 408 & 409 \\ 409 & 409 & 410 \\ 410 & 410 & 411 \\ 411 & 411 & 412 \\ 412 & 412 & 413 \\ 413 & 413 & 414 \\ 414 & 414 & 415 \\ 415 & 415 & 416 \\ 416 & 416 & 417 \\ 417 & 417 & 418 \\ 418 & 418 & 419 \\ 419 & 419 & 420 \\ 420 & 420 & 421 \\ 421 & 421 & 422\end{array}$

(191) > \$\$ MEMBER FOR NORTH GALLERY WALL

\{ 192\} > MEMBER INCIDENCES

( 193$\}>502 \quad 502 \quad 503$

( 194) > GENERATE 11 MEMBERS ID 503 FROM 503 INC 1 TO 504 INC 1

\begin{tabular}{lll} 
MEMBER & \multicolumn{2}{c}{ MEMBER INCIDENCES } \\
503 & 503 & 504 \\
504 & 504 & 505 \\
505 & 505 & 506 \\
506 & 506 & 507 \\
507 & 507 & 508 \\
508 & 508 & 509 \\
509 & 509 & 510 \\
510 & 510 & 511 \\
511 & 511 & 512 \\
512 & 512 & 513 \\
513 & 513 & 514
\end{tabular}

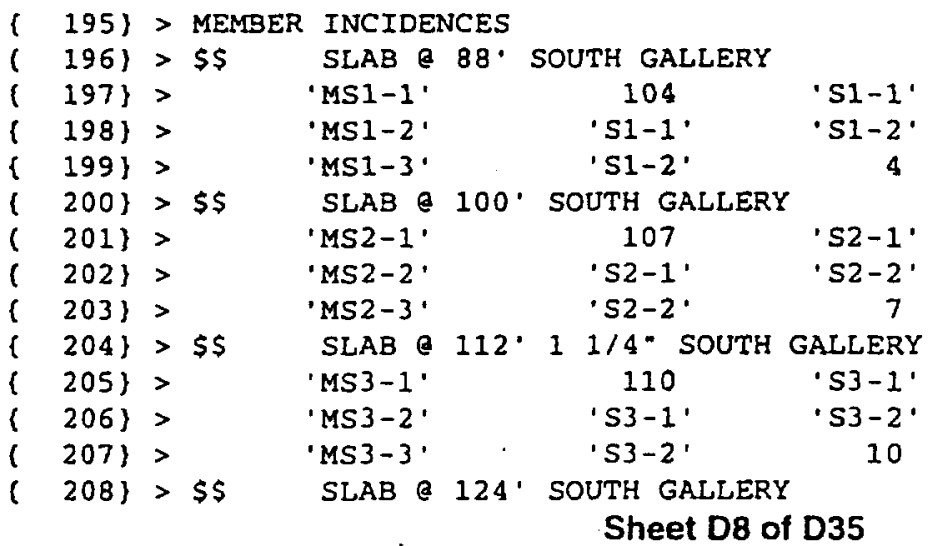

ATTTACHMENT-D: Calc. No. 0200W-CA-C0156 Rev. No. 0 Job No. 22192 
BHI-01299

Rev. 0

Attachment D: REDOX (Corrected Coordinates in "GT Strudl" Model) Output for Seismic Analysis (Using Original Ground Response Spectrum for $10 \%$ Damping)

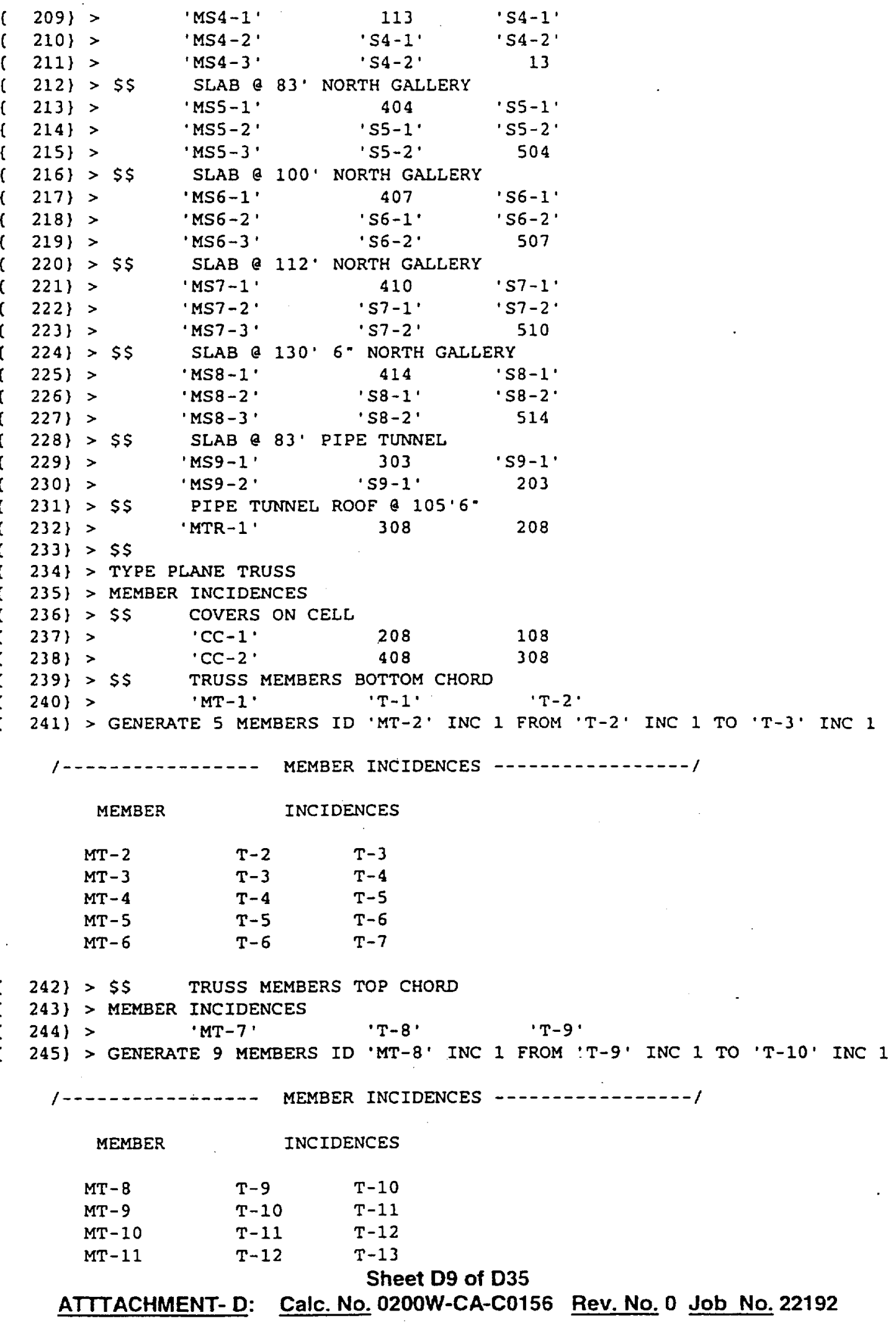


BHI-01299

Rev. 0

Attachment D: REDOX (Corrected Coordinates in "GT Strudl" Model) Output for Seismic Analysis (Using Original Ground Response Spectrum for 10\% Damping)

$\begin{array}{lll}M T-12 & T-13 & T-16 \\ M T-13 & T-14 & T-15 \\ M T-14 & T-15 & T-16 \\ M T-15 & T-16 & T-17 \\ M T-16 & T-17 & T-18\end{array}$

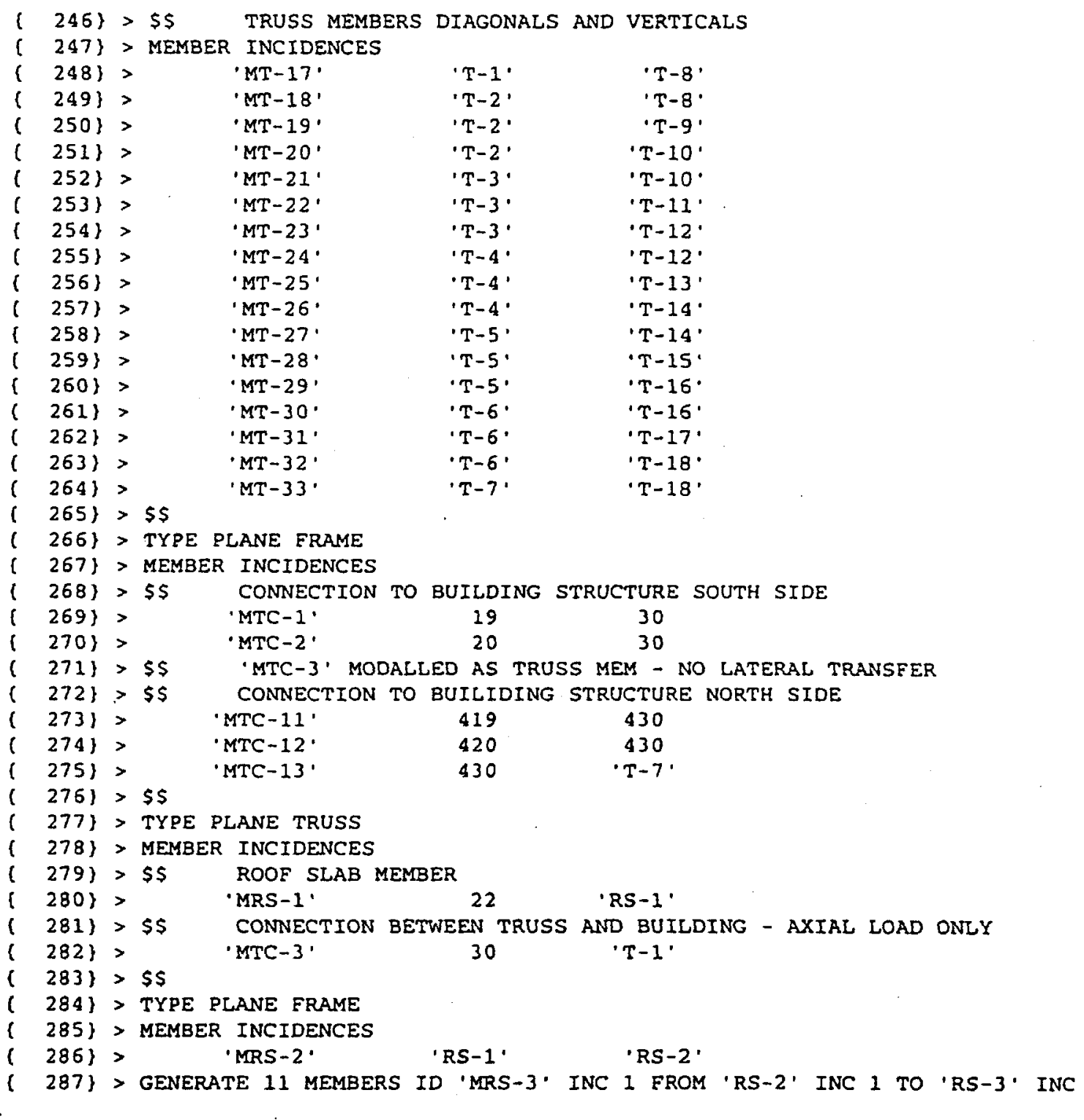

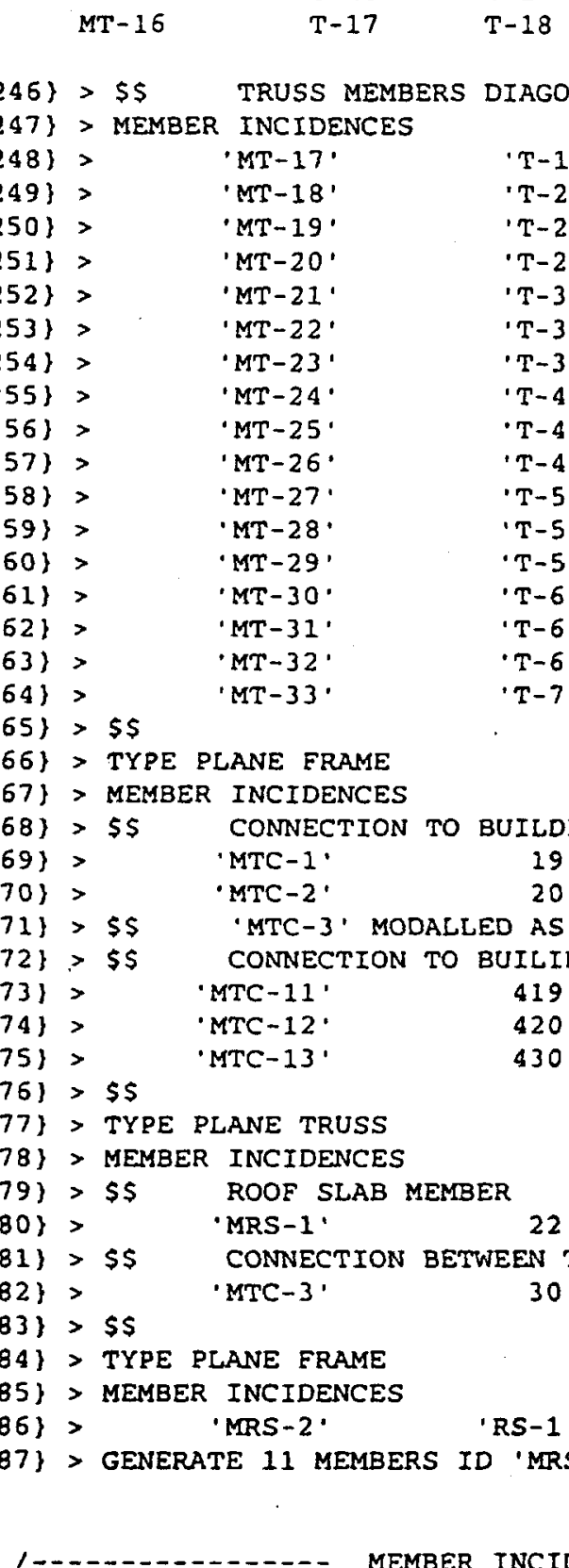

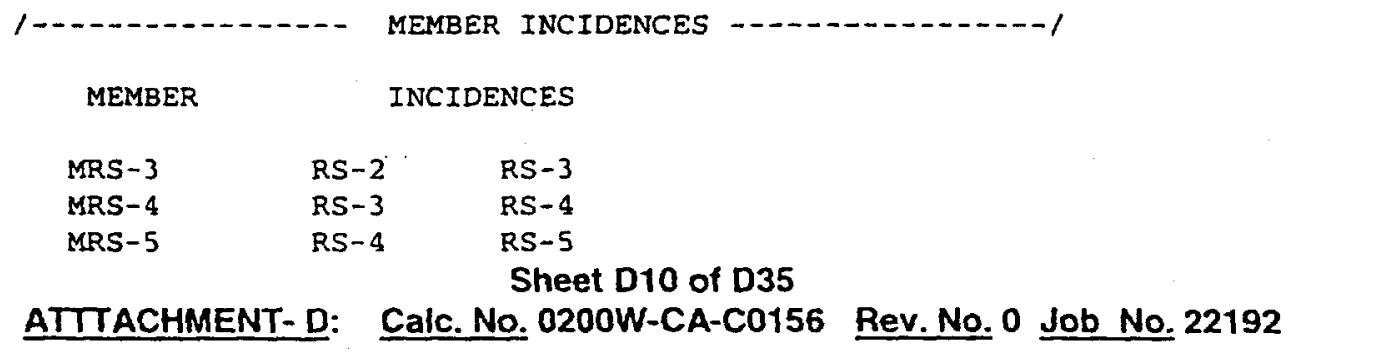


Attachment D: REDOX (Corrected Coordinates in "GT Strudl" Model) Output for Seismic Analysis (Using-Original Ground Response Spectrum for 10\% Damping)

$\begin{array}{lll}\text { MRS-6 } & \text { RS-5 } & \text { RS-6 } \\ \text { MRS-7 } & \text { RS-6 } & \text { RS-7 } \\ \text { MRS-8 } & \text { RS-7 } & \text { RS-8 } \\ \text { MRS-9 } & \text { RS-8 } & \text { RS-9 } \\ \text { MRS-10 } & \text { RS-9 } & \text { RS-10 } \\ \text { MRS-11 } & \text { RS-10 } & \text { RS- } 11 \\ \text { MRS-12 } & \text { RS-11 } & \text { RS-12 } \\ \text { MRS-13 } & \text { RS-12 } & \text { RS-13 }\end{array}$

(288\} > MEMBER INCIDENCES

$(289)^{\prime}>$ 'MRS-14' 'RS-13' 422

(290) > \$\$ CONNECTION BETWEEN ROOF SLAB AND TRUSS

( 291) > TYPE PLANE TRUSS

( 292) > MEMBER INCIDENCES

( 293) > 'MTRS-1. 'T-8' 'RS-2'

(294) > GENERATE 10 MEMBERS ID 'MTRS-2' INC 1 FROM 'T-9' INC 1 TO 'RS-3' INC 1

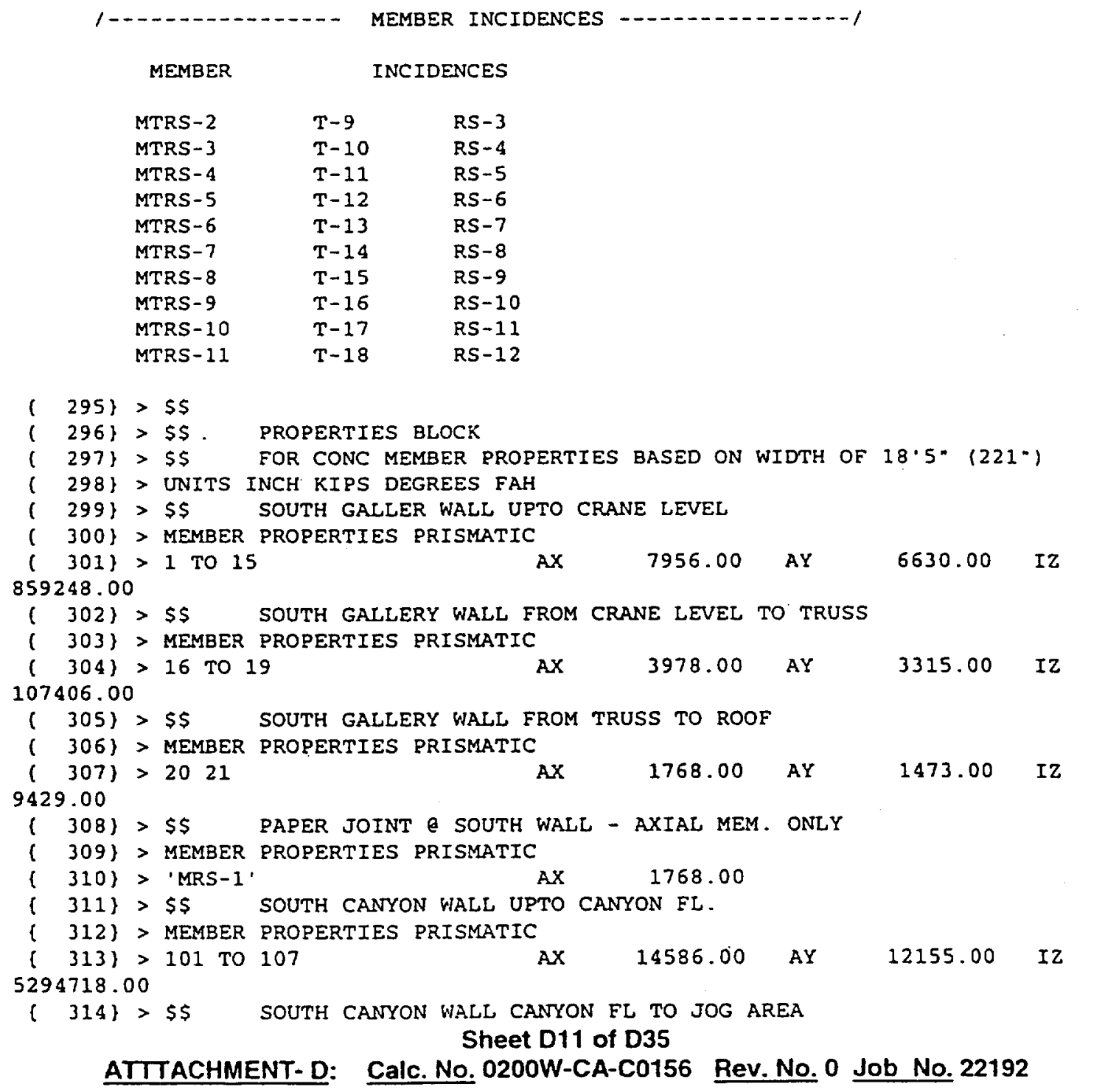


BHI-01299

Rev. 0

Attachment D: REDOX (Corrected Coordinates in "GT Strudl" Model) Output for Seismic Analysis (Using Original Ground Response Spectrum for 10\% Damping)

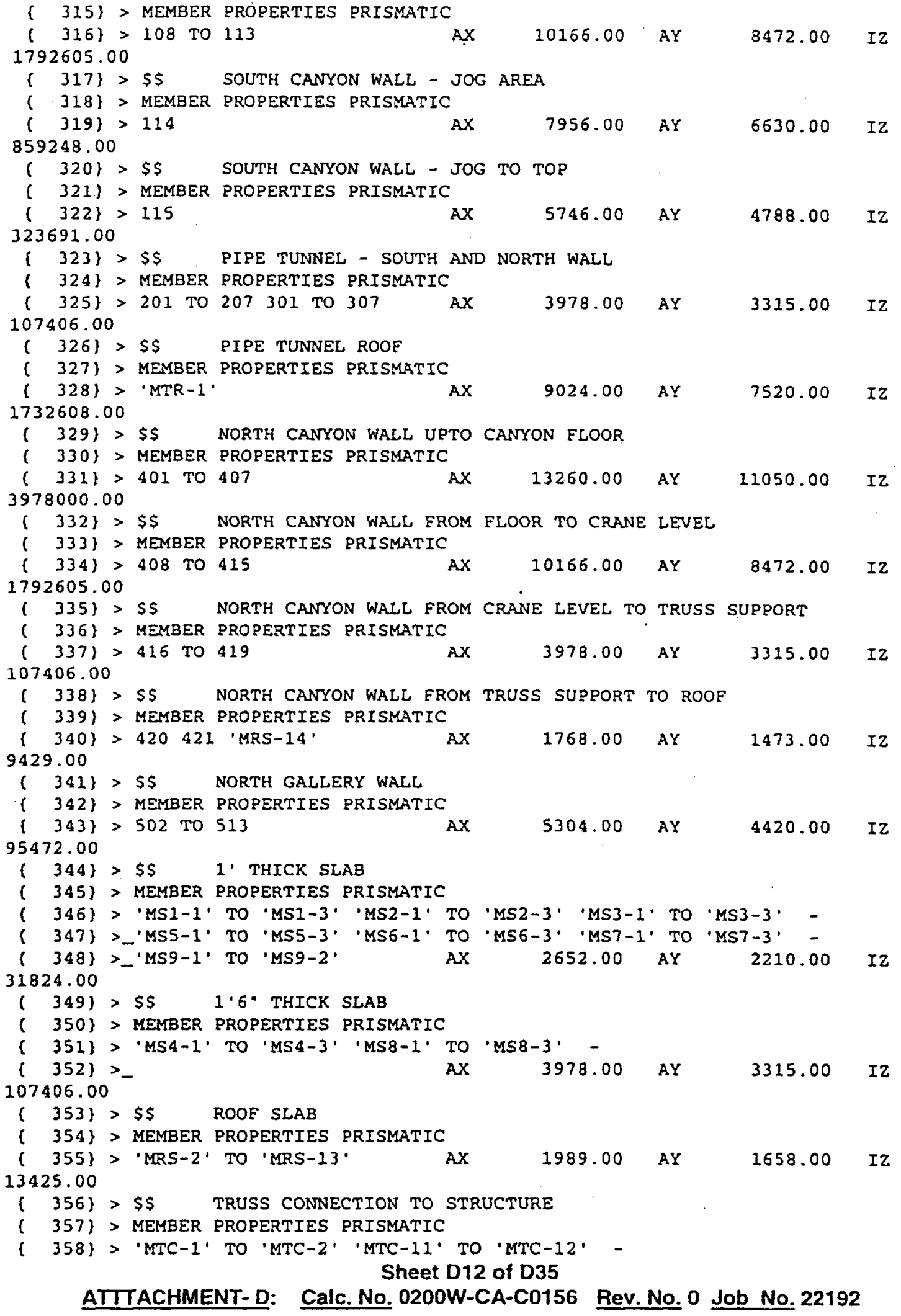


Attachment D: REDOX (Corrected Coordinates in "GT Strudl" Model) Output for Seismic Analysis (Using Original Ground Response Spectrum for 10\% Damping)

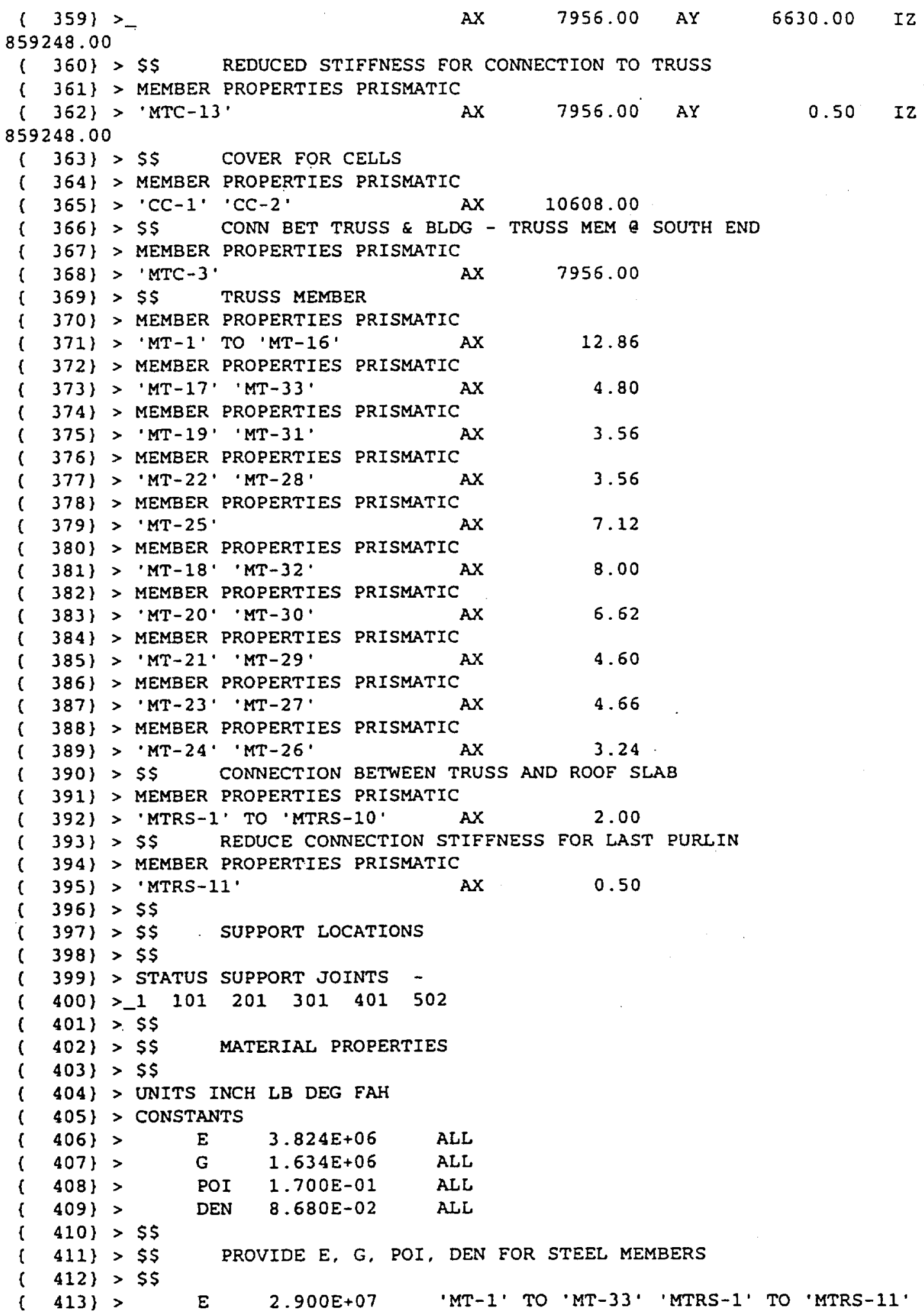

\section{Sheet D13 of D35}

ATTTACHMENT-D: Calc. No. 0200W-CA-C0156 Rev. No. 0 Job No. 22192 
Attachment D: REDOX (Corrected Coordinates in "GT Strudl" Model) Output for Seismic Analysis (Using Original Ground Response Spectrum for 10\% Damping)

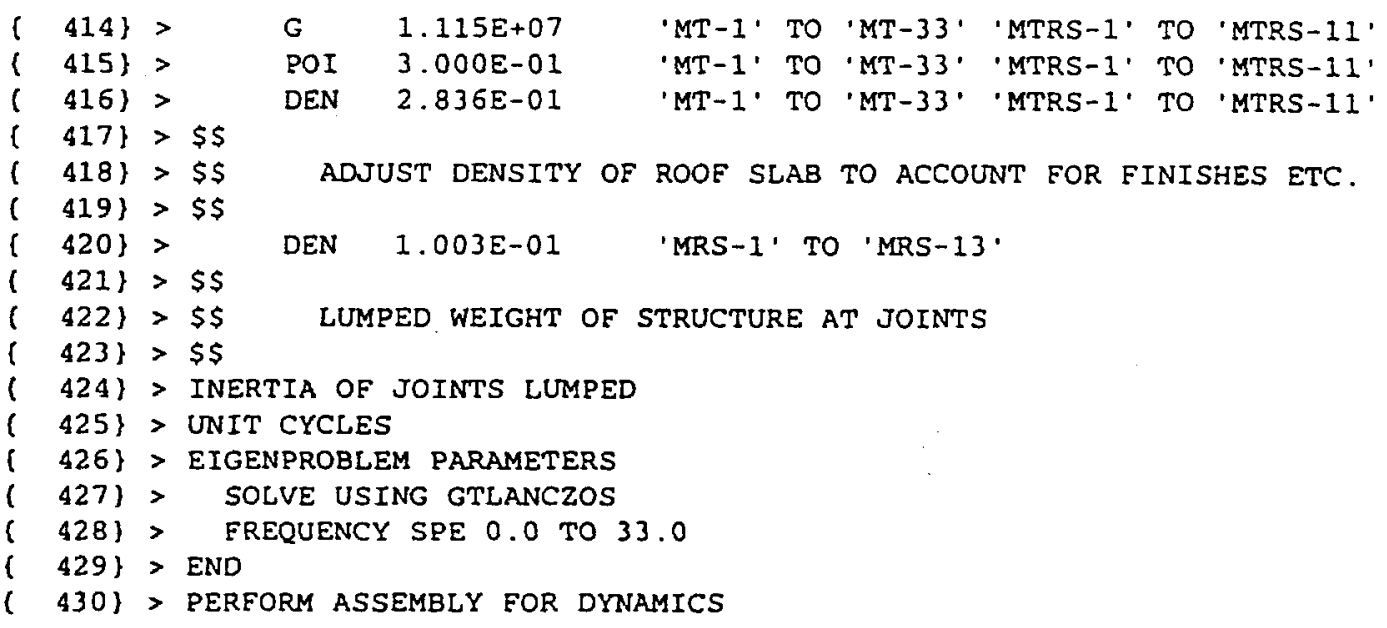

BANDWIDTH INFORMATION BEFORE RENUMBERING.

THE MAXIMUM BANDWIDTH IS 100 AND OCCURS AT JOINT RS-1 THE AVERAGE BANDWIDTH IS 11.165 THE STANDARD DEVIATION OF THE BANDWIDTH IS 21.338

BANDWIDTH INFORMATION AFTER RENUMBERING.

THE MAXIMUM BANDWIDTH IS THE AVERAGE BANDWIDTH IS 9 AND OCCURS AT JOINT $57-2$ 5.511 THE STANDARD DEVIATION OF THE BANDWIDTH IS 1.914 7.425 TIME FOR CONSISTENCY CHECK FOR 176 MEMBERS. 0.00 SECONDS TIME FOR BANDWIDTH REDUCTION 0.02 SECONDS TIME TO GENERATE 176 ELEMENT STIF. MATRICES 0.01 SECONDS TIME TO ASSEMBLE THE STIFFNESS MATRIX 0.02 SECONDS TIME TO PROCESS 139 JOINTS 0.00 SECONDS TIME TO GENERATE REDUCED STIFFNESS MATRIX 0.01 SECONDS TIME TO ASSEMBLE LUMPED MASS MATRIX (431) > PERFORM EIGENVALUE ANALYSIS *** STRUDL MESSAGE DY.409 - THERE ARE 22 FREQUENCIES LESS THAN OR EQUAL TO THE SPECIFIED MAXIMUM FREQUENCY

TIME TO SOLVE EIGENPROBLEM TIME TO TRANSFORM EIGENVECTORS TO JOINTS

0.35 SECONDS

0.02 SECONDS

\section{Sheet D14 of Di35}

ATITACHMENT-D: Calc. No. 0200W-CA-C0156 Rev. No. 0 Job No. 22192 
Attachment D: REDOX (Corrected Coordinates in "GT Strudl" Model) Output for Seismic Analysis (Using Original Ground Response Spectrum for 10\% Damping)

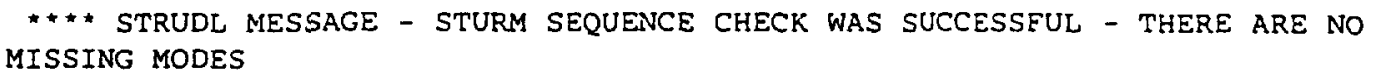

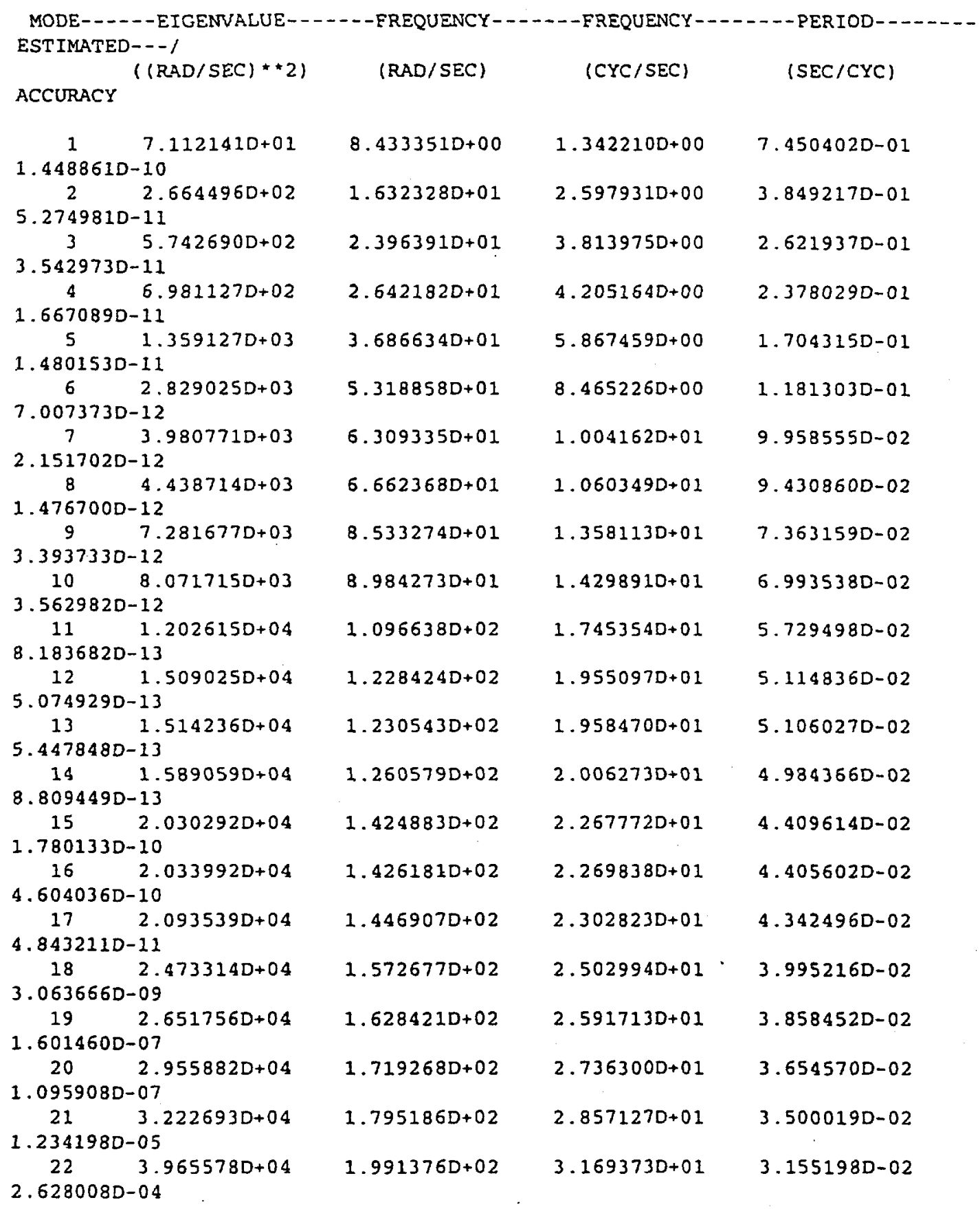


This page cannot be converted.

Please view the native document

for the original page. 
BHI-01299

Rev. 0

Attachment D: REDOX (Corrected Coordinates in "GT Strudl" Model) Output for Seismic Analysis (Using Original Ground Response Spectrum for 10\% Damping)

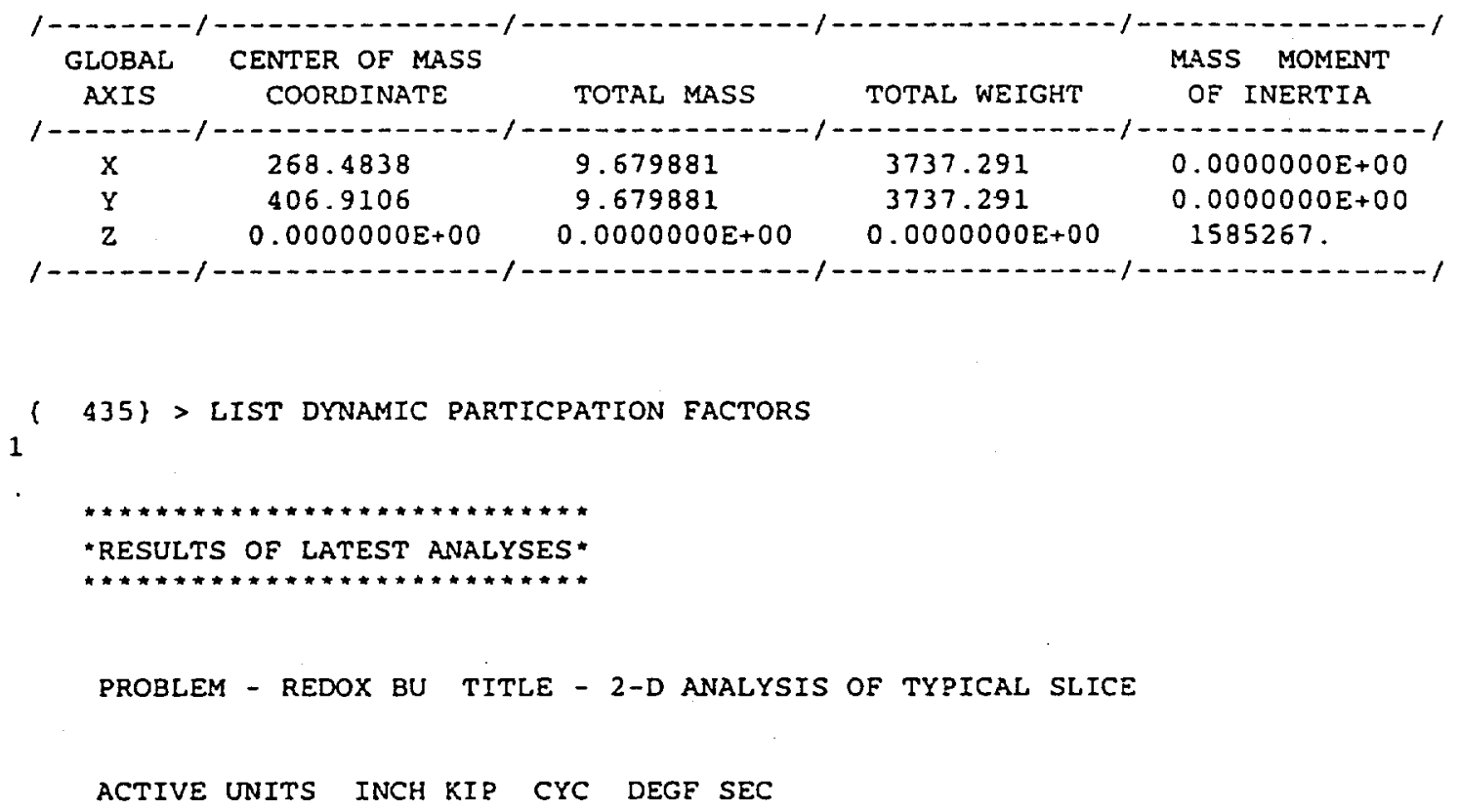

NORMALIZED PARTICIPATION FACTORS

\begin{tabular}{|c|c|c|c|c|c|c|c|}
\hline MODE & PERCENT & MODE & PERCENT & MODE & PERCENT & MODE & PERCENT \\
\hline MODE & PERCENT & MODE & PERCENT & & & & \\
\hline 1 & 18.46657 & 2 & 38.16778 & 3 & 7.350529 & 4 & 3.477863 \\
\hline 5 & 5.428569 & 6 & .9735833 & & & & \\
\hline 7 & 8.256175 & 8 & 0.8782288 & 9 & 0.2912734 & 10 & 2.317298 \\
\hline 11 & $0.7019849 E-01$ & 12 & 1.013797 & & & & \\
\hline 13 & $0.6517125 \mathrm{E}-02$ & 14 & $0.5610686 E-02$ & 15 & $0.1501943 \mathrm{E}-03$ & 16 & $0.9461575 E-01$ \\
\hline 17 & $0.1340575 E-02$ & 18 & 0.8813852 & & & & \\
\hline 19 & 0.5527257 & 20 & 0.9036222 & 21 & 0.2137198 & 22 & $0.7448741 \mathrm{E}-02$ \\
\hline
\end{tabular}

TOTAL PERCENTAGE OF $X$ DTRECTION MASS PARTICIPATING: 89.359

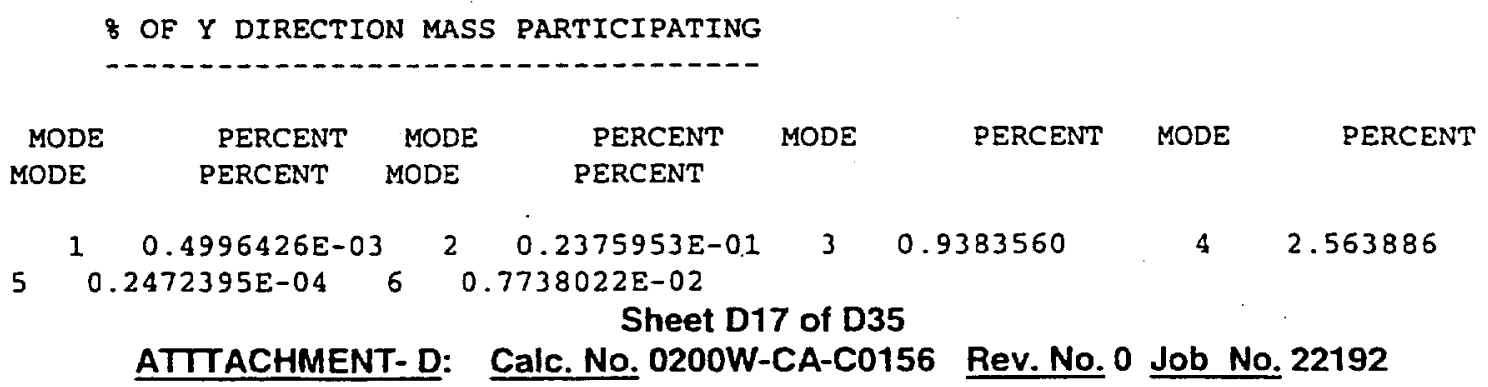


BHI-01299

Rev. 0

Attachment D: REDOX (Corrected Coordinates in "GT Strud" Model) Output for Seismic Analysis (Using Original Ground Response Spectrum for 10\% Damping)

\begin{tabular}{|c|c|c|c|c|c|c|c|}
\hline 7 & $0.8796270 \mathrm{E}$ & 8 & $0.2613380 \mathrm{E}-03$ & 9 & $0.4690954 E-02$ & 10 & $0.2258782 \mathrm{E}-02$ \\
\hline 11 & 1.007529 & 12 & $0.6989779 E-02$ & & & & \\
\hline 13 & 0.2568285 & 14 & 2.968185 & 15 & 4.597464 & 16 & $0.4055185 E-01$ \\
\hline 7 & 0.4691689 & 18 & 4.987041 & & & & \\
\hline 19 & 0.1043740 & 20 & 0.7674618 & 21 & 0.8030278 & 22 & 1.941544 \\
\hline
\end{tabular}

TOTAL PERCENTAGE OF $Y$ DIRECTION MASS PARTICIPATING: 21.493

NO MASS IN 2 DIRECTION

$(436)>\$ \$$

(437) > UNITS EEET SECONDS

(438) > DELETE RESPONSE SPECTRA 'RSH'

*** STRUDL ERROR DY.81 - FILE RSH DOES NOT EXIST ON USER DATA SET

( 439 ) > STORE RESPONSE SPECTRA ACCELERATION LOG VS FREQUENCY LOG 'RSH'

( 440$)>$ DAMPING 0.10 EACTOR 32.2

( 441$)>\$ \$$ SPECTRA IN g's

$\begin{array}{llllllllllll}(442)>0.12 & 100.0 & 0.12 & 33.0 & 0.20 & 7.1 & 0.20 & 1.67 & 0.028 & 0.77\end{array}$

( 443 ) > RESPONSE SPECTRA LOAD 1

( 444) > SUPPORT ACCELERATION

(445) > TRANSLATIONAL $X 1.00$ FILE 'RSH'

(446) > END RESPONSE SPECTRA LOADING

( 447 ) > DAMPING RATIO 0.1030

( 448) > PEREORM RESPONSE SPECTRA ANALYSIS

TIME TO COMPUTE RESPONSE SPECTRA RESULTS

( 449) > COMPUTE RESPONSE SPECTRA DISPLACEMENT ACC FORCES REACTIONS -

$\{450\}>$ MODAL COMBINATION NRC TPM

TIME FOR RESPONSE SPECTRA COMPUTATION 0.49 SECONDS

$\{451\}>\$ \$$

( 452 ) > CREATE PSEUDO STATIC LOAD 'NS' FROM NRC TPM LOAD 1

(453) > LIST RESPONSE SPECTRUM SPECTRAL ACCELERATION

1

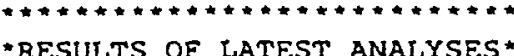

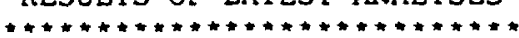

PROBLEM - REDOX BU TITLE - 2-D ANALYSIS OF TYPICAL SLICE

ACTIVE UNITS FEET KIP CYC DEGF SEC

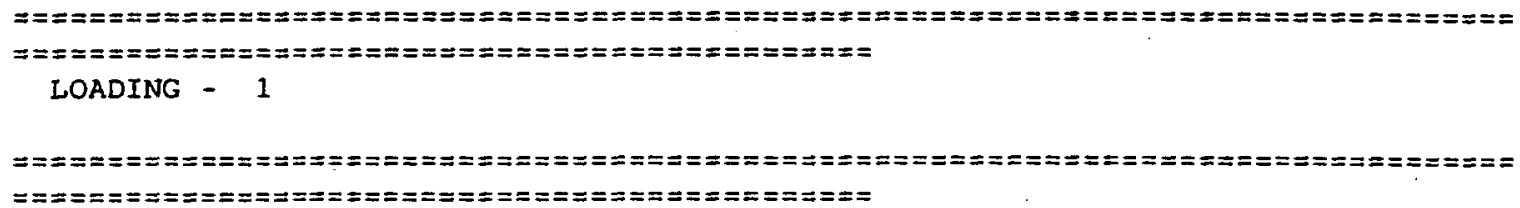

Sheet D18 of D35

ATTIACHMENT-D: Calc. No. 0200W-CA-C0156 Rev. No. 0 Job No. 22192 
Attachment D: REDOX (Corrected Coordinates in "GT Strudl" Model) Output for Seismic Analysis (Using Original Ground Response Spectrum for 10\% Damping)

SPECTRAL ACCELERATIONS

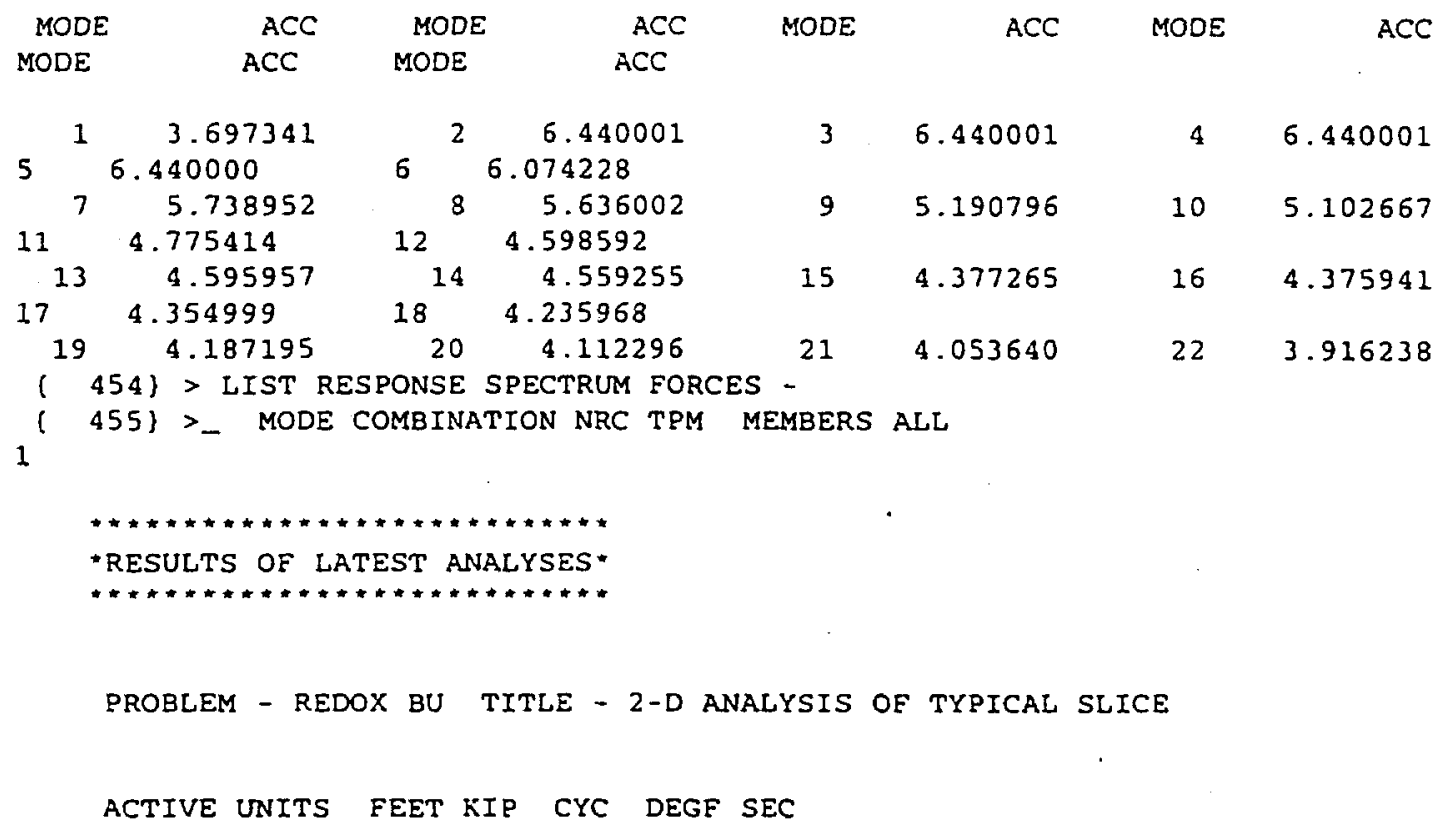

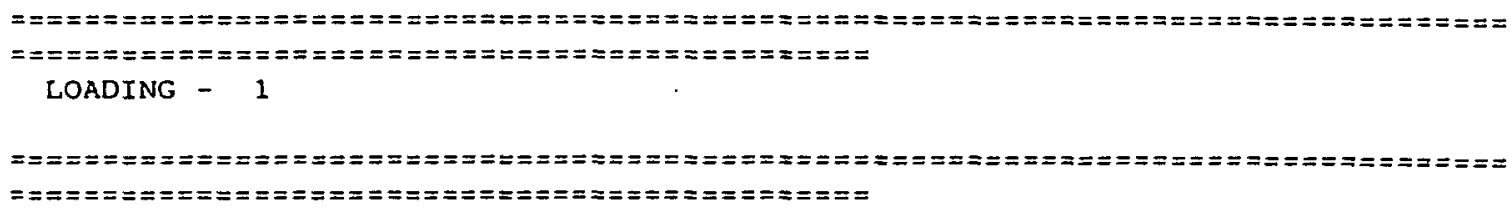

MEMBER FORCES

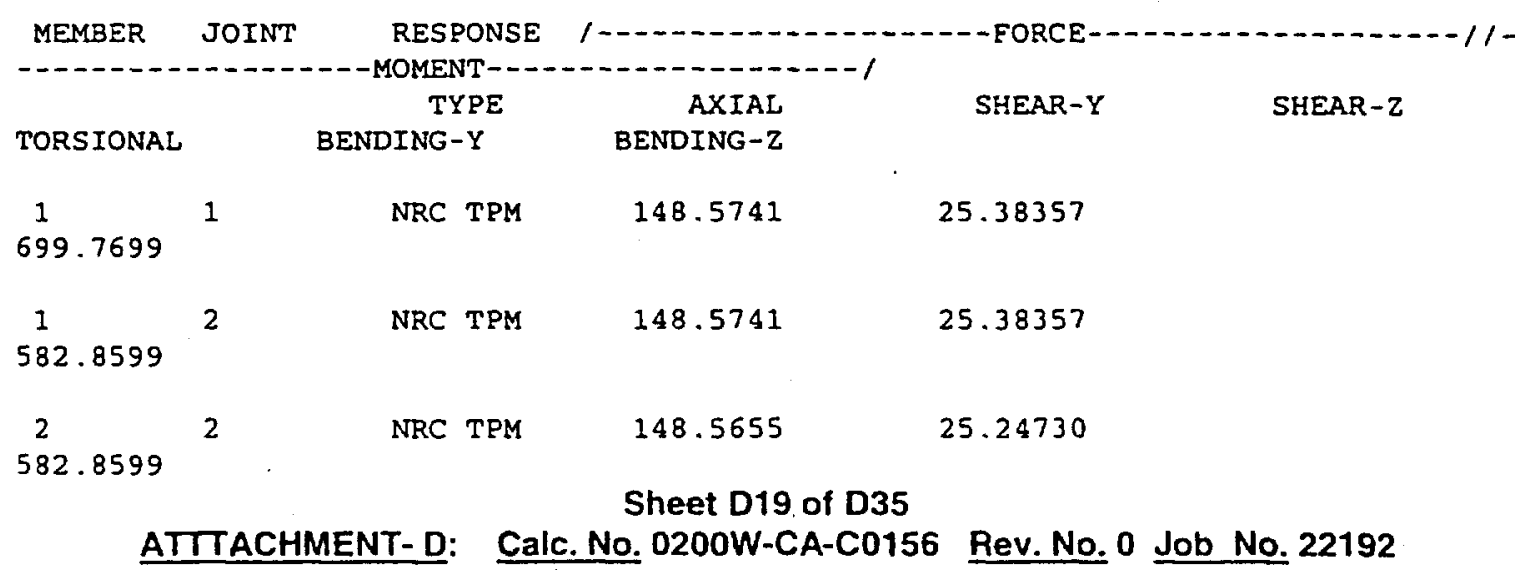


BHI-01299

Rev. 0

Attachment D: REDOX (Corrected Coordinates in "GT Strudl" Model) Output for Seismic Analysis (Using Original Ground Response Spectrum for 10\% Damping)

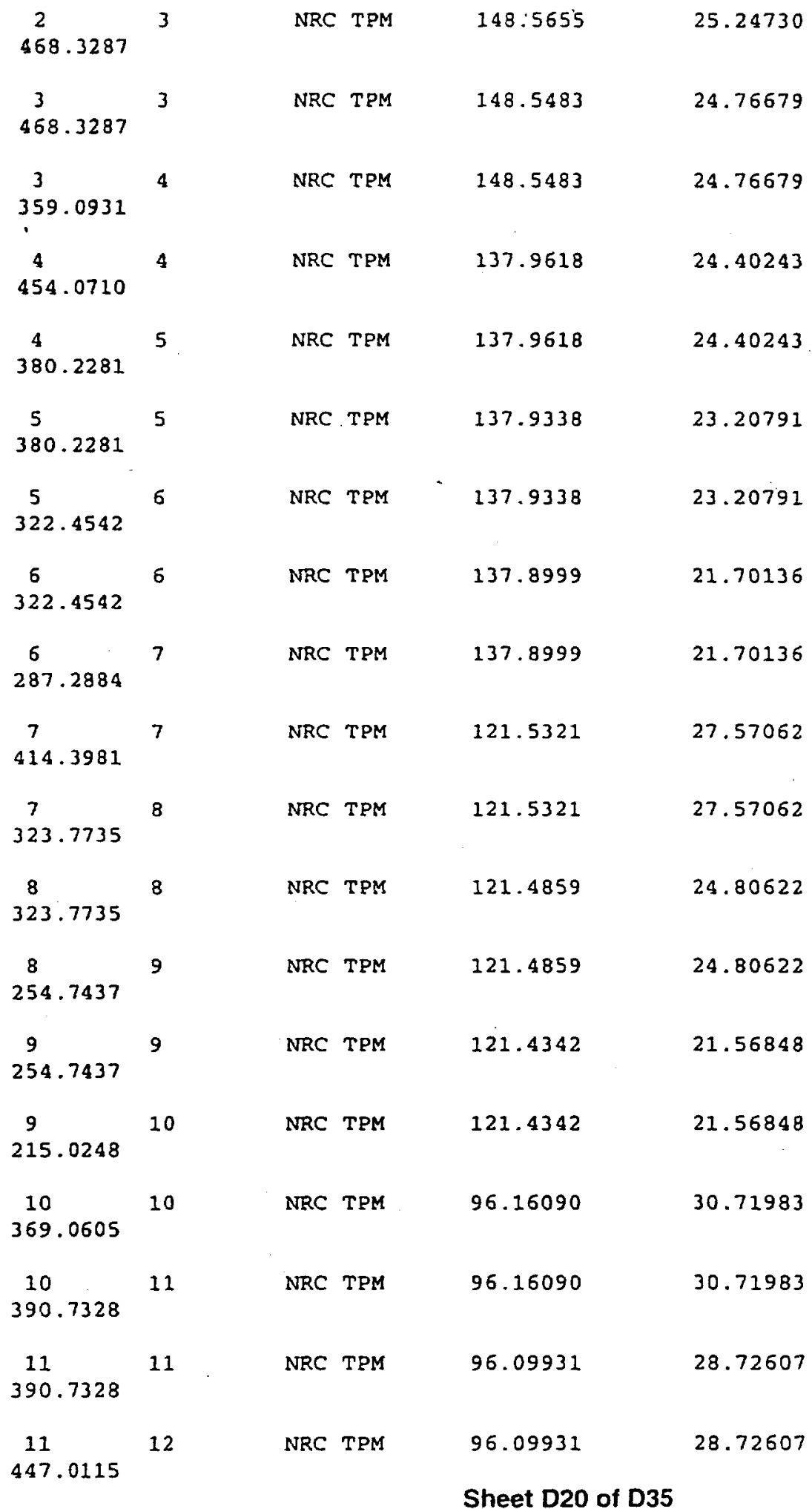

ATTTACHMENT-D: Calc. No. 0200W-CA-C0156 Rev. No. 0 Job No. 22192 
BHI-0I 299

Rev. 0

Attachment D: REDOX (Corrected Coordinates in "GT Strudl" Model) Output for Seismic Analysis (Using Original Ground Response Spectrum for 10\% Damping)

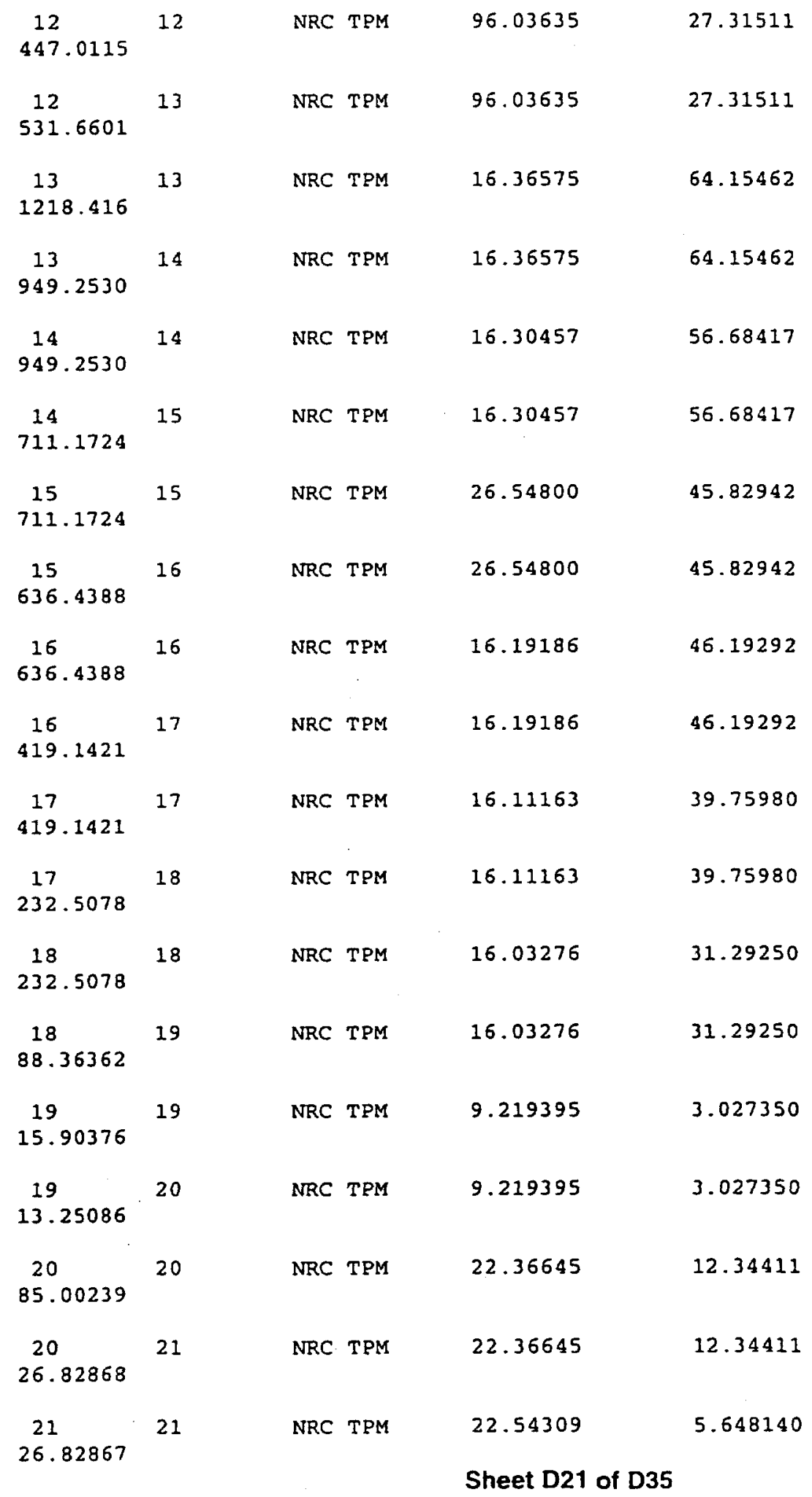

ATITACHMENT-D: Calc. No. 0200W-CA-C0156 Rev. No. 0 Job No. 22192 
BHI-0I 299

Rev. 0

Attachment D: REDOX (Corrected Coordinates in "GT Strudl" Model) Output for Seismic Analysis (Using Original Ground Response Spectrum for 10\% Damping)

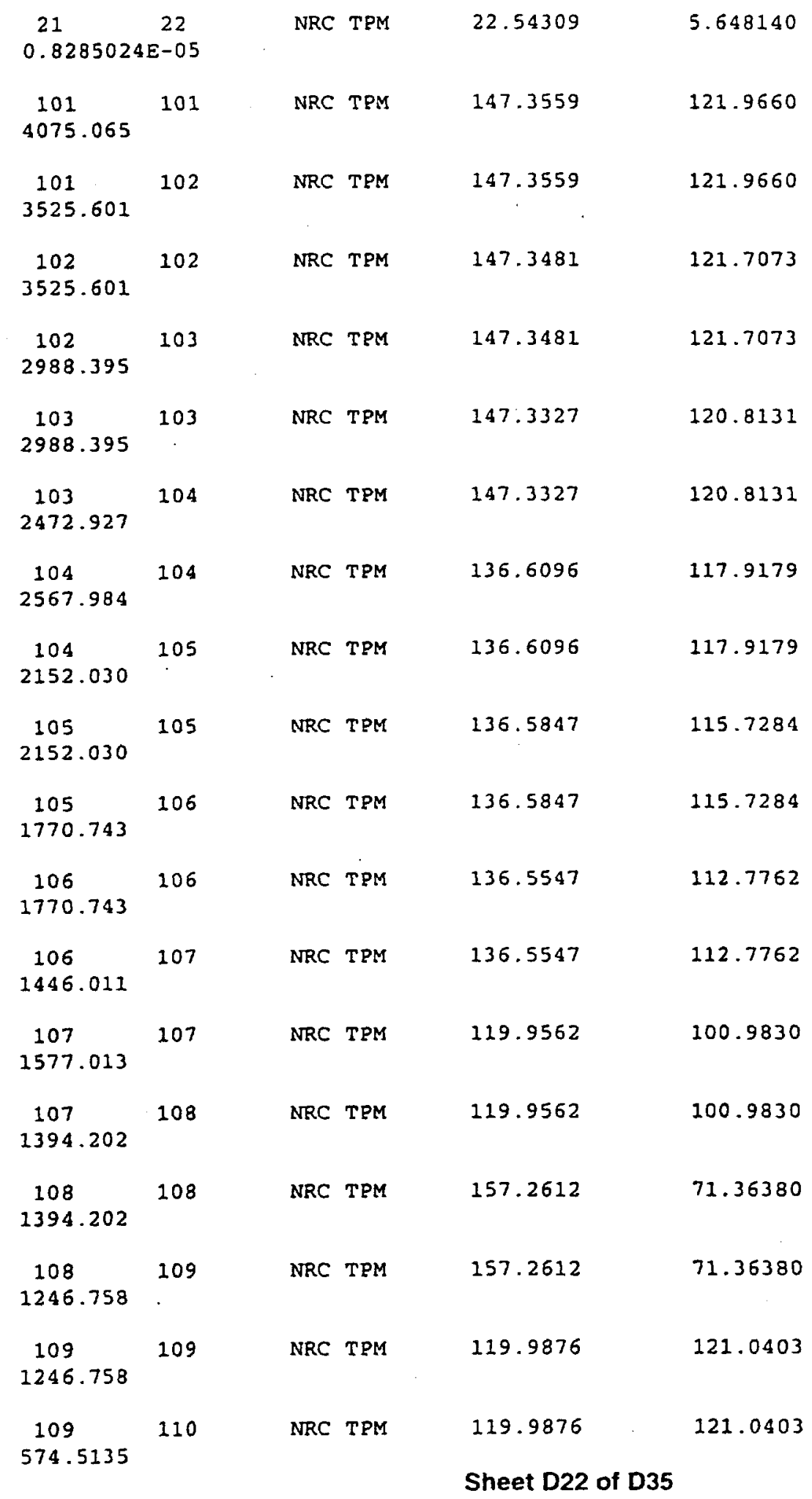

ATTTACHMENT-D: Calc. No. 0200W-CA-C0156 Rev. No. 0 Job No. 22192 
BHI-01299

Rev. 0

Attachment D: REDOX (Corrected Coordinates in "GT Strudl" Model) Output for Seismic Analysis (Using Original Ground Response Spectrum for 10\% Damping)

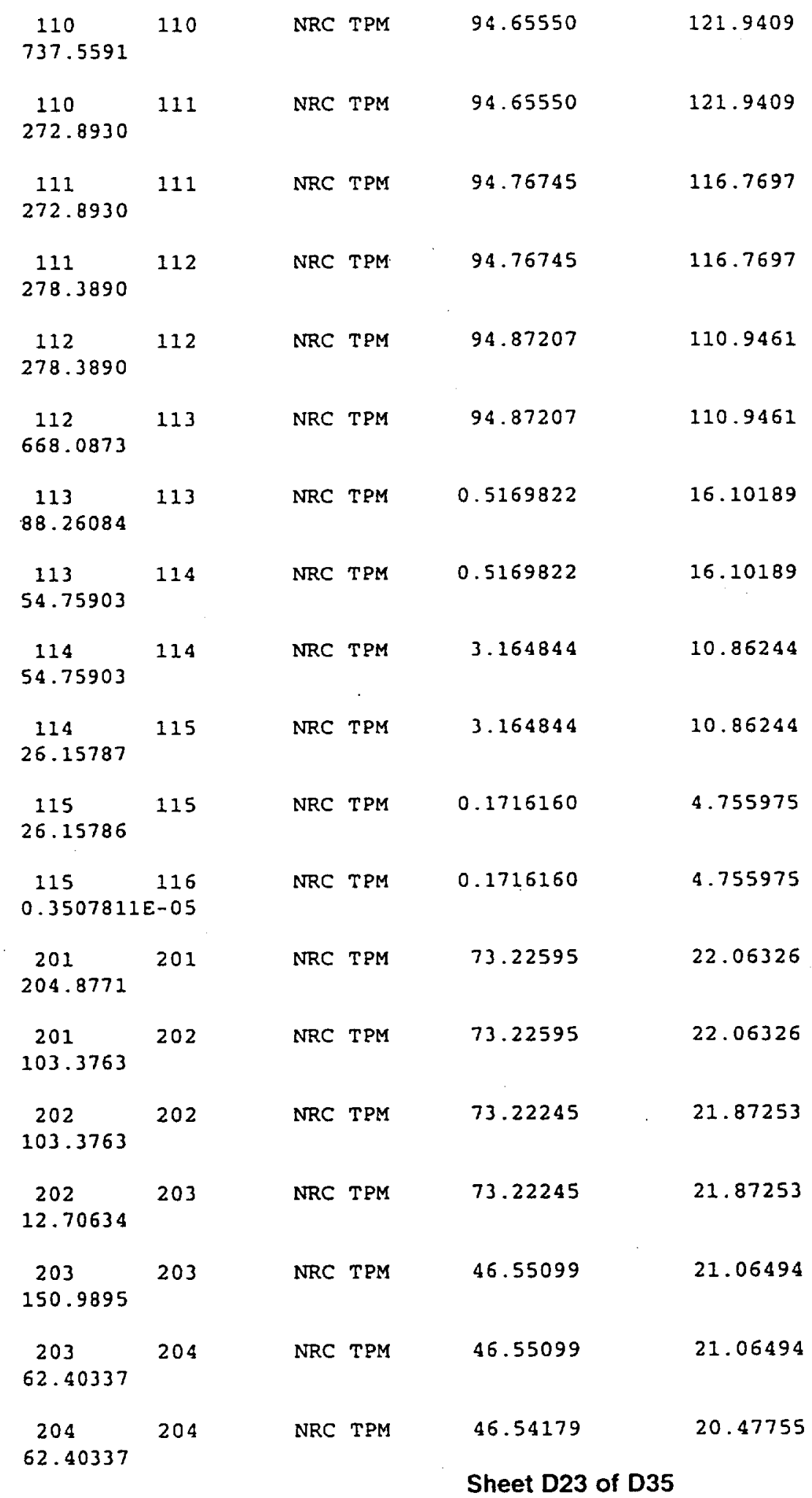

ATTTACHMENT-D: Calc. No. 0200W-CA-C0156 Rev. No. 0 Job No. 22192 
BHI-01299

Rev. 0 Attachment D: $\frac{\text { REDOX (Corrected Coordinates in "GT Strud)" Model) Output for Seismic Analysis }}{\text { (Using Original Ground Response Spectrum for } 10 \% \text { Damping) }}$

\begin{tabular}{|c|c|c|c|c|c|}
\hline $\begin{array}{l}204 \\
27.08814\end{array}$ & 205 & $\mathrm{NRC}$ & TPM & 46.54179 & 20.47755 \\
\hline $\begin{array}{l}205 \\
27.08814\end{array}$ & 205 & NRC & TPM & 46.53028 & 19.68454 \\
\hline $\begin{array}{l}205 \\
108.8308\end{array}$ & 206 & NRC & TPM & 46.53028 & 19.68454 \\
\hline $\begin{array}{l}206 \\
108.8308\end{array}$ & 206 & NRC & TPM & 46.51647 & 18.66412 \\
\hline $\begin{array}{l}206 \\
187.4967\end{array}$ & 207 & NRC & TQM & 46.51647 & 18.66412 \\
\hline $\begin{array}{l}207 \\
187.4967\end{array}$ & 207 & NRC & TPM & 45.03674 & 20.80206 \\
\hline $\begin{array}{l}207 \\
69.95593\end{array}$ & 208 & NRC & TPM & 45.03674 & 20.80206 \\
\hline $\begin{array}{c}301 \\
204.9005\end{array}$ & 301 & NRC & TPM & 73.22771 & 22.07143 \\
\hline $\begin{array}{l}301 \\
103.3628\end{array}$ & 302 & NRC & TPM & 73.22771 & 22.07143 \\
\hline $\begin{array}{c}302 \\
103.3628\end{array}$ & 302 & NRC & TPM & 73.22421 & 21.88067 \\
\hline $\begin{array}{l}302 \\
12.70993\end{array}$ & 303 & NRC & TPM & 73.22421 & 21.88067 \\
\hline $\begin{array}{l}303 \\
150.9342\end{array}$ & 303 & NRC & TPM & 46.55322 & 21.05910 \\
\hline $\begin{array}{l}303 \\
62.37303\end{array}$ & 304 & NRC & TPM & 46.55322 & 21.05910 \\
\hline $\begin{array}{c}304 \\
62.37303\end{array}$ & 304 & NRC & TPM & 46.54401 & 20.47200 \\
\hline $\begin{array}{l}304 \\
27.09489\end{array}$ & 305 & NRC & TPM & 46.54401 & 20.47200 \\
\hline $\begin{array}{l}305 \\
27.09489\end{array}$ & 305 & NRC & TPM & 46.53248 & 19.67936 \\
\hline $\begin{array}{l}305 \\
108.8161\end{array}$ & 306 & NRC & TPM & 46.53248 & 19.67936 \\
\hline $\begin{array}{l}306 \\
108.8161\end{array}$ & 306 & NRC & TPM & 46.51865 & 18.65947 \\
\hline $\begin{array}{c}306 \\
187.4620\end{array}$ & 307 & NRC & TPM & $\begin{array}{l}46.51865 \\
\text { Sheet D24 }\end{array}$ & 18.65947 \\
\hline
\end{tabular}

ATTTACHMENT-D: Calc. No. $0200 W-C A-C 0156$ Rev. No. 0 Job No. 22192 
BHI-01299

Rev 0

Attachment D: REDOX (Corrected Coordinates in "GT Strudl" Model) Output for Seismic Analysis (Using Original Ground Response Spectrum for $10 \%$ Damping)

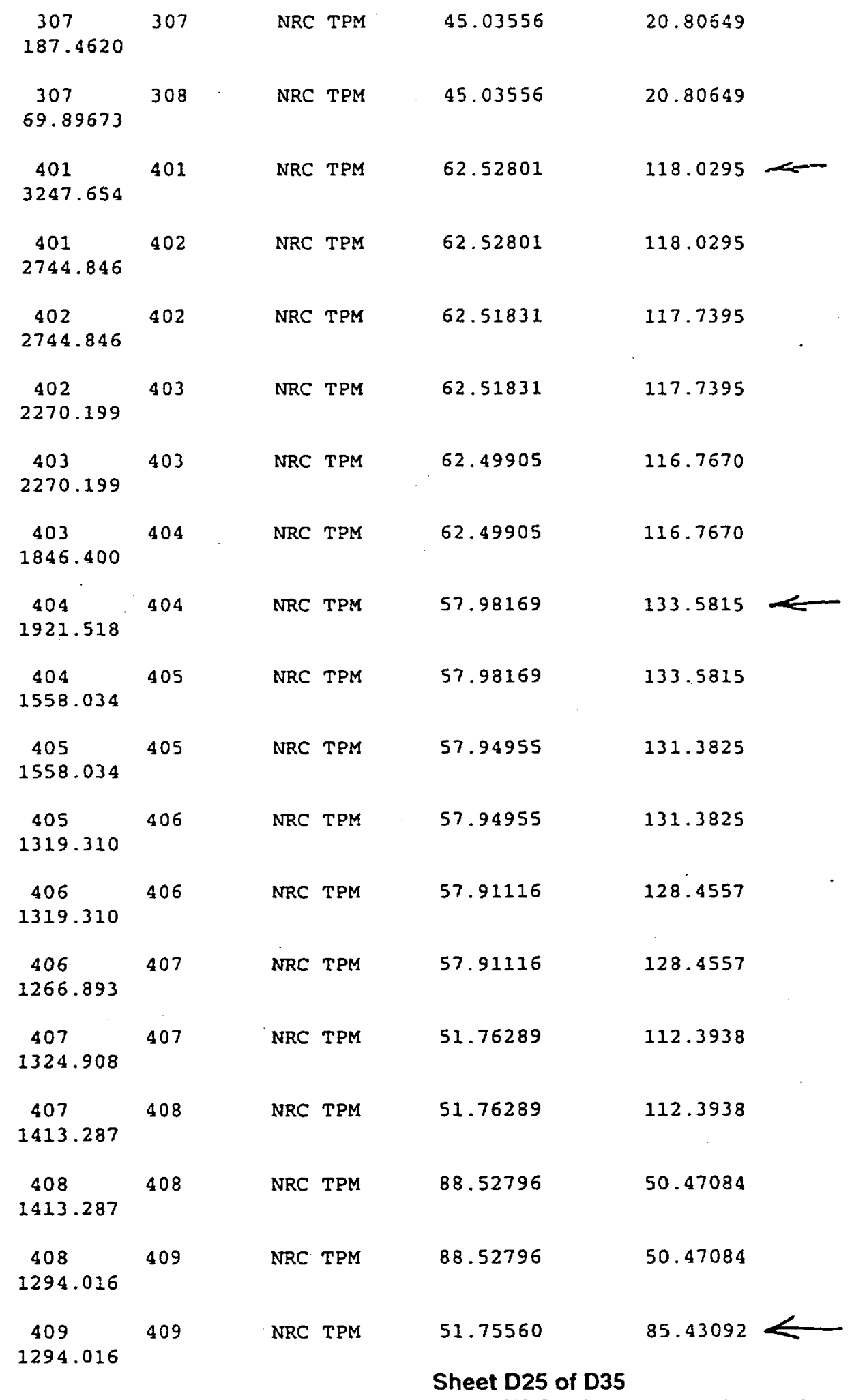

ATTTACHMENT-D: Calc. No. 0200 W-CA-C0156 Rev. No. 0 Job No. 22192 
BHI-01299

Rev. 0

Attachment D: REDOX (Corrected Coordinates in "GT Strudl" Model) Output for Seismic Analysis (Using Original Ground Response Spectrum for $10 \%$ Damping)

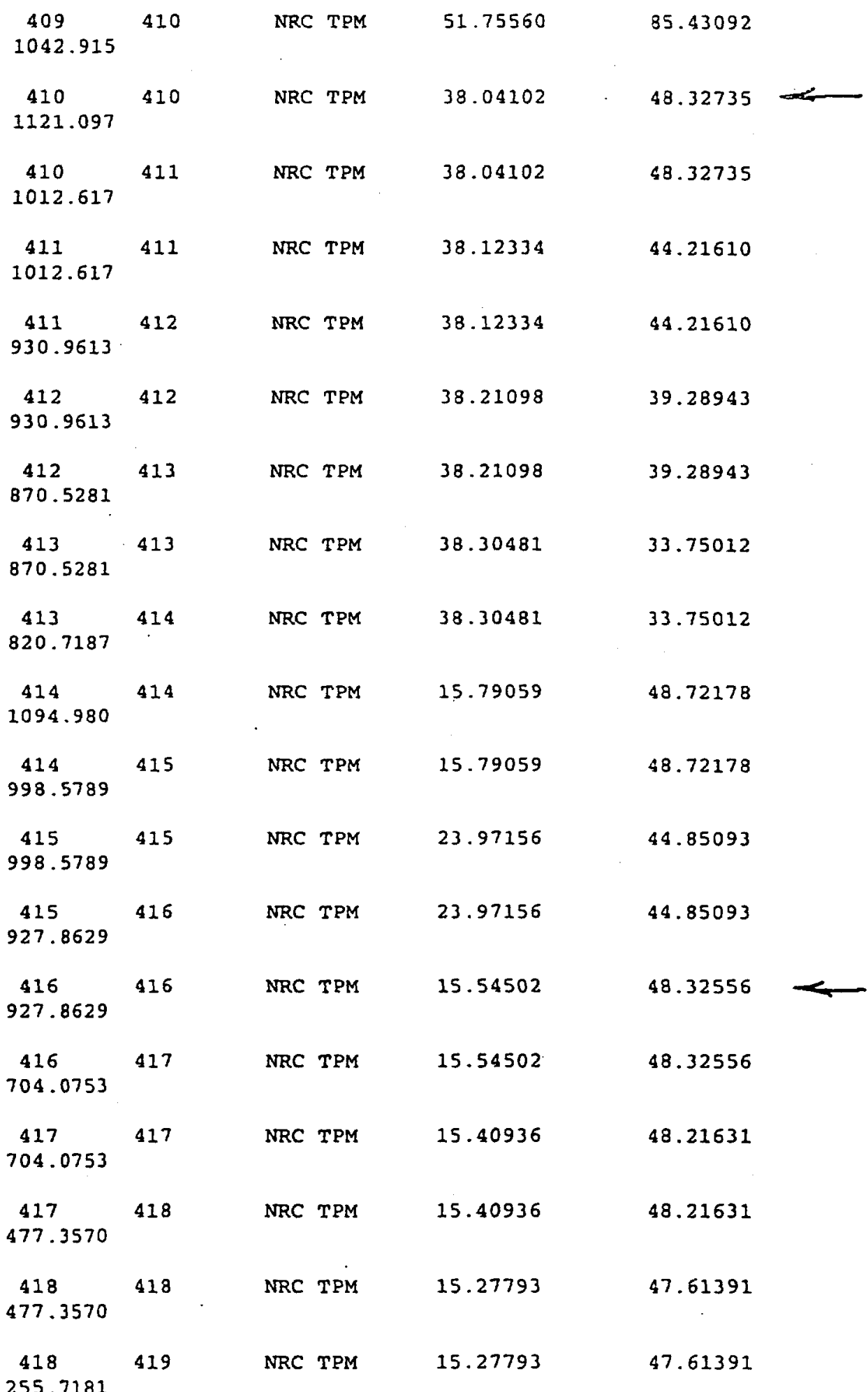

\section{Sheet D26 of D35}

ATTTACHMENT-D: Calc. No. 0200 W-CA-C0156 Rev. No. 0 Job No. 22192 
BHI-01299

Rev. 0

Attachment D: REDOX (Corrected Coordinates in "GT Strudl" Model) Output for Seismic Analysis (Using Original Ground Response Spectrum for 10\% Damping)

\begin{tabular}{|c|c|c|c|c|c|}
\hline $\begin{array}{c}419 \\
46.48323\end{array}$ & 419 & NRC & TPM & 14.88875 & 13.99131 \\
\hline $\begin{array}{l}419 \\
33.84514\end{array}$ & 420 & NRC & TPM & 14.88875 & 13.99131 \\
\hline $\begin{array}{l}420 \\
207.3488\end{array}$ & 420 & NRC & TPM & 14.88417 & 44.41880 \\
\hline $\begin{array}{l}420 \\
25.94268\end{array}$ & 421 & NRC & $T P M$ & 14.88417 & 44.41880 \\
\hline $\begin{array}{c}421 \\
25.94267\end{array}$ & 421 & NRC & TPM & 14.87057 & 43.15236 \\
\hline $\begin{array}{l}421 \\
211.0225\end{array}$ & 422 & NRC & TPM & 14.87057 & 43.15236 \\
\hline $\begin{array}{l}502 \\
241.7060\end{array}$ & 502 & NRC & $T P M$ & 67.63821 & 29.53745 \\
\hline $\begin{array}{l}502 \\
102.1538\end{array}$ & 503 & NRC & TPM & 67.63821 & 29.53745 \\
\hline $\begin{array}{l}503 \\
102.1538\end{array}$ & 503 & NRC & TPM & 67.63345 & 29.31079 \\
\hline $\begin{array}{c}503 \\
39.43371\end{array}$ & 504 & NRC & TPM & 67.63345 & 29.31079 \\
\hline $\begin{array}{c}504 \\
47.98573\end{array}$ & 504 & NRC & TPM & 62.78803 & 6.946240 \\
\hline $\begin{array}{l}504 \\
27.24990\end{array}$ & 505 & NRC & TPM & 62.78803 & 6.946240 \\
\hline $\begin{array}{l}505 \\
27.24990\end{array}$ & 505 & NRC & TPM & 62.77636 & 5.984046 \\
\hline $\begin{array}{c}505 \\
23.13253\end{array}$ & 506 & NRC & TPM & 62.77636 & 5.984046 \\
\hline $\begin{array}{l}506 \\
23.13253\end{array}$ & 506 & NRC & TPM & 62.76145 & 5.066161 \\
\hline $\begin{array}{l}506 \\
33.65217\end{array}$ & 507 & NRC & TPM & 62.76145 & 5.066161 \\
\hline $\begin{array}{l}507 \\
82.01856\end{array}$ & 507 & NRC & TPM & 55.95660 & 11.79092 \\
\hline $\begin{array}{l}507 \\
66.35854\end{array}$ & 508 & NRC & TPM & 55.95660 & 11.79092 \\
\hline $\begin{array}{l}508 \\
65.35854\end{array}$ & 508 & NRC & TPM & 55.93439 & 9.947743 \\
\hline
\end{tabular}

ATTTACHMENT-D: Calc. No. $0200 W-C A-C 0156$ Rev. No. 0 Job No. 22192 
Attachment D: REDOX (Corrected Coordinates in "GT Strudl" Model) Output for Seismic Analysis (Using Original Ground Response Spectrum for 10\% Damping)

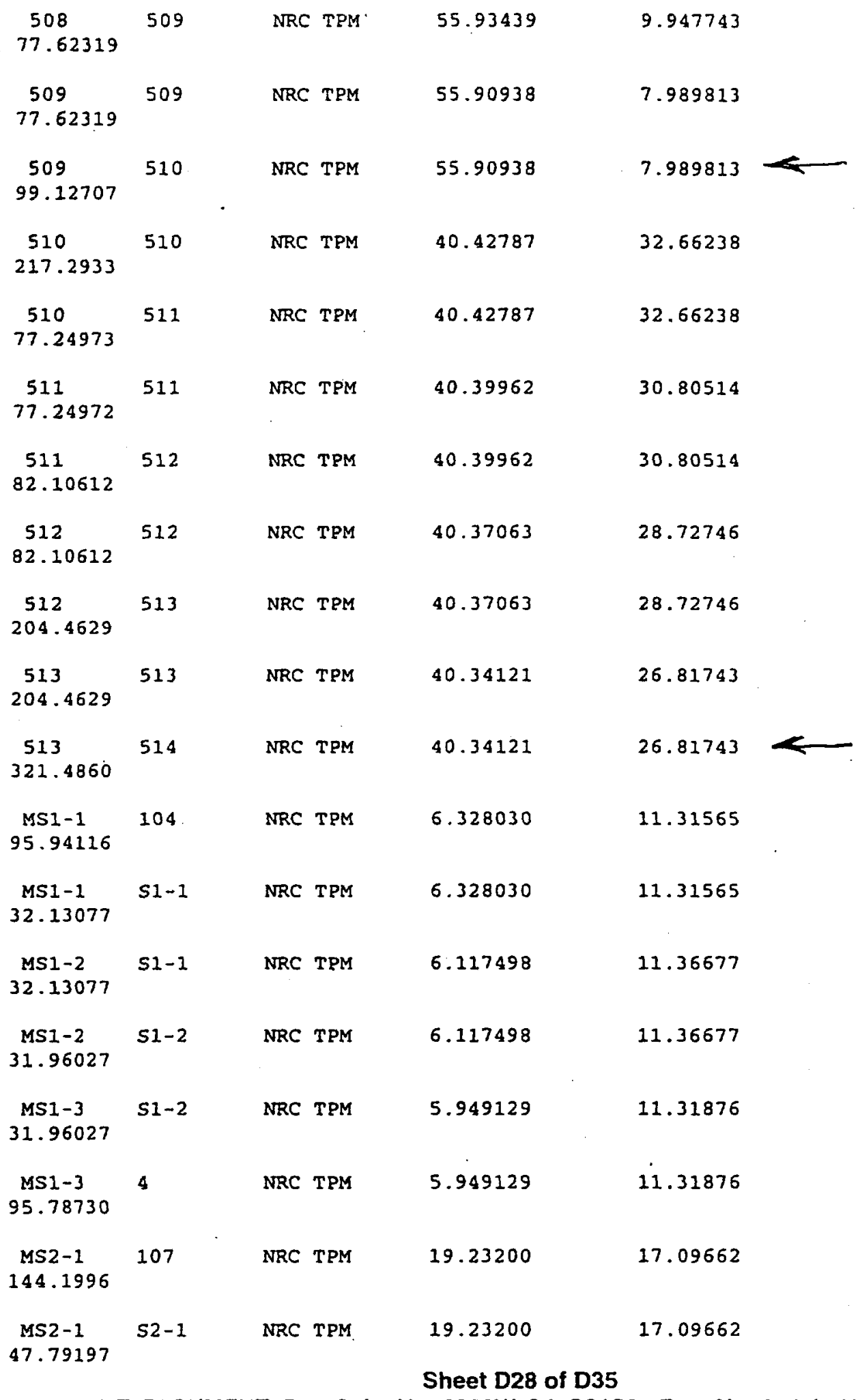

ATTTACHMENT-D: Calc. No. $0200 W-C A-C 0156$ Rev. No. 0 Job No. 22192 
BHI-01299

Rev. 0

Attachment D: REDOX (Corrected Coordinates in "GT Strudl" Model) Output for Seismic Analysis (Using Original Ground Response Spectrum for 10\% Damping)

\begin{tabular}{|c|c|c|c|c|c|}
\hline $\begin{array}{c}\text { MS2-2 } \\
47.79197\end{array}$ & $s 2-1$ & NRC & TPM & 18.30879 & 17.16765 \\
\hline $\begin{array}{c}\text { MS2-2 } \\
49.01332\end{array}$ & $s 2-2$ & NRC & TPM & 18.30879 & 17.16765 \\
\hline $\begin{array}{c}\text { MS2-3 } \\
49.01332\end{array}$ & $s 2-2$ & NRC & TPM & 17.42957 & 17.09662 \\
\hline $\begin{array}{c}\text { MS2-3 } \\
145.4205\end{array}$ & 7 & NRC & TPM & 17.42957 & 17.09662 \\
\hline $\begin{array}{c}\text { MS3-1 } \\
209.1889\end{array}$ & 110 & NRC & TPM & 31.27639 & 25.67324 \\
\hline $\begin{array}{c}\text { MS3-1 } \\
85.81319\end{array}$ & s3-1 & NRC & $\mathrm{TPM}$ & 31.27639 & 25.67324 \\
\hline $\begin{array}{c}M S 3-2 \\
85.81319\end{array}$ & $53-1$ & NRC & TPM & 31.15229 & 25.82949 \\
\hline $\begin{array}{c}M S 3-2 \\
59.84162\end{array}$ & $53-2$ & NRC & TPM & 31.15229 & 25.82949 \\
\hline $\begin{array}{c}\text { MS3-3 } \\
59.84162\end{array}$ & $53-2$ & NRC & $T P M$ & 31.13084 & 25.77378 \\
\hline $\begin{array}{c}M S 3-3 \\
205.1753\end{array}$ & 10 & NRC & TPM & 31.13084 & 25.77378 \\
\hline $\begin{array}{c}\text { MS4-1 } \\
743.9662\end{array}$ & 113 & NRC & TPM & 91.50966 & 95.36941 \\
\hline $\begin{array}{c}\text { MS4-1 } \\
285.8461\end{array}$ & S4-1 & NRC & TPM & 91.50966 & 95.36941 \\
\hline $\begin{array}{c}\text { MS4-2 } \\
285.8461\end{array}$ & $54-1$ & NRC & TPM & 88.25334 & 95.56870 \\
\hline $\begin{array}{c}\text { MS4-2 } \\
253.6837\end{array}$ & $54-2$ & NRC & $T P M$ & 88.25334 & 95.56870 \\
\hline $\begin{array}{c}\text { MS4-3 } \\
253.6837\end{array}$ & $54-2$ & NRC & TPM & 84.84252 & 95.40062 \\
\hline $\begin{array}{c}\text { MS4-3 } \\
791.4054\end{array}$ & 13 & NRC & TPM & 84.84252 & 95.40062 \\
\hline $\begin{array}{c}\text { MS5-1 } \\
77.55231\end{array}$ & 404 & NRC & TPM & 20.95688 & 6.931415 \\
\hline $\begin{array}{l}\text { MS5-1 } \\
24.94038\end{array}$ & $55-1$ & NRC & TPM & 20.95688 & 6.931415 \\
\hline $\begin{array}{c}\text { MS5-2 } \\
24.94038\end{array}$ & S5-1 & $\mathrm{NRC}$ & TPM & 21.32795 & 6.999121 \\
\hline
\end{tabular}

ATITACHMENT-D: Calc. No. 0200W-CA-C0156 Rev. No. 0 Job No. 22192 
Attachment D: REDOX (Corrected Coordinates in "GT Strudl" Model) Output for Seismic Analysis (Using Original Ground Response Spectrum for $10 \%$ Damping)

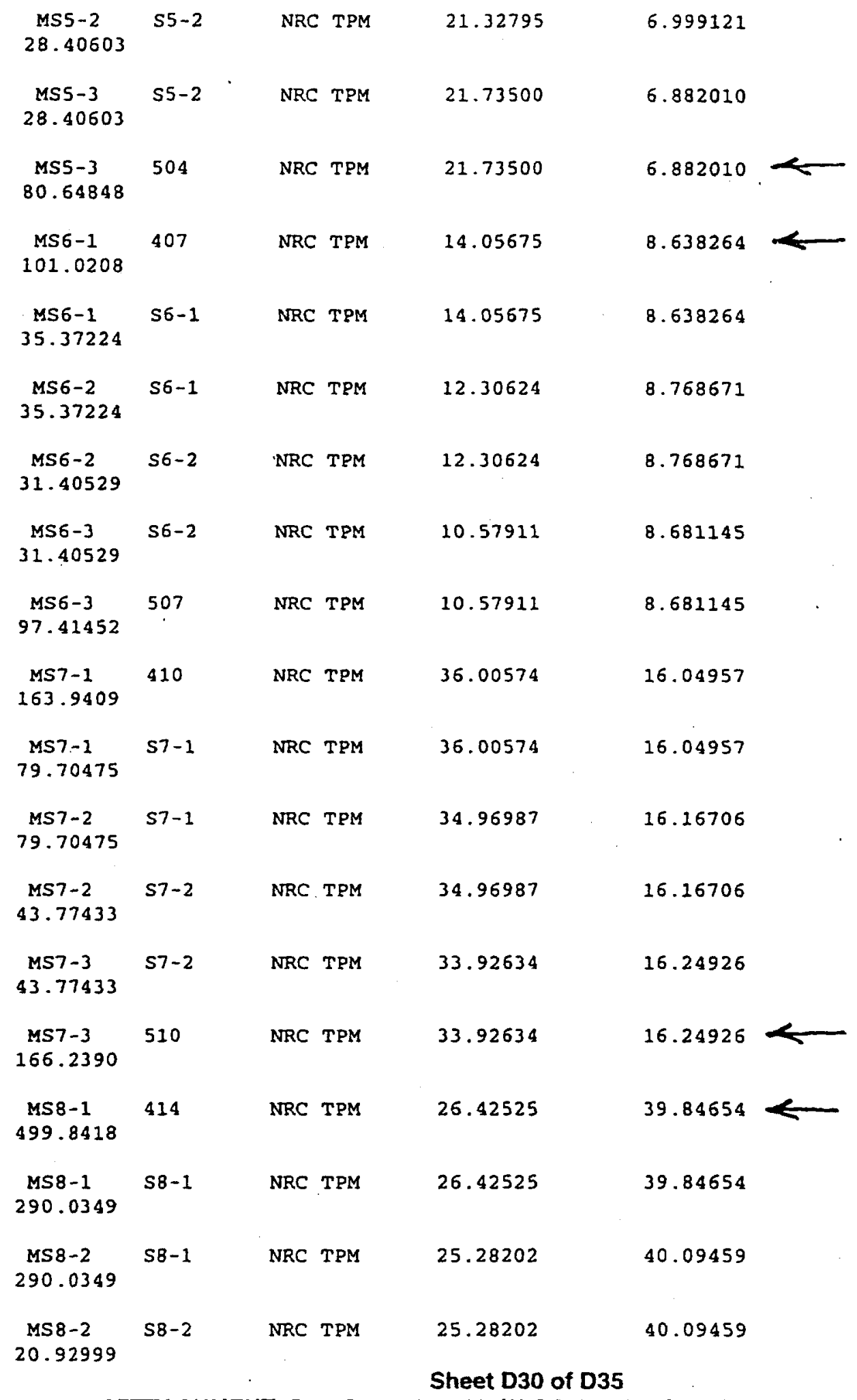

ATITACHMENT-D: Calc. No. 0200W-CA-C0156 Rev. No. 0 Job No. 22192 

Attachment D: $\frac{\text { REDOX (Corrected Coordinates in "GT Strudl" Model) Output for Seismic Analysis }}{\text { (Using Original Ground Response Spectrum for 10\% Damping) }}$

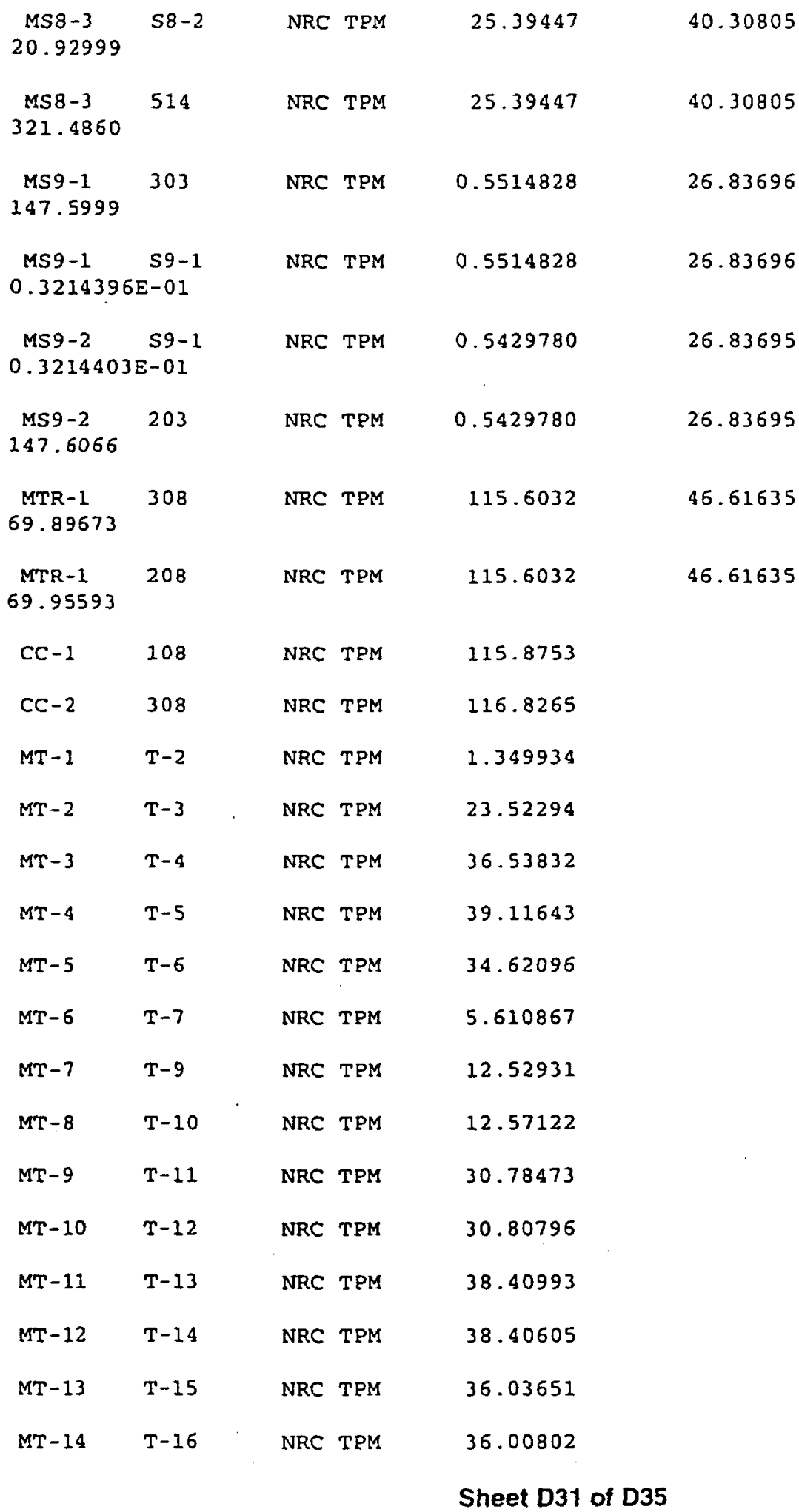

ATTTACHMENT-D: Calc. No. 0200W-CA-C0156 Rev. No. 0 Job No. 22192 
Attachment D: REDOX (Corrected Coordinates in "GT Strudl" Model) Output for Seismic Analysis (Using Original Ground Response Spectrum for $10 \%$ Damping)

\begin{tabular}{|c|c|c|c|c|c|}
\hline$M T-15$ & $T-17$ & NRC & TPM & 23.57310 & \\
\hline$M T-16$ & $T-18$ & NRC & TPM & 23.53853 & \\
\hline $\mathrm{MT}-17$ & $T-8$ & NRC & $T P M$ & 23.88051 & \\
\hline $\mathrm{MT}-18$ & $T-8$ & NRC & TPM & 20.01964 & \\
\hline MT- 19 & $T-9$ & NRC & TPM & 1.964458 & \\
\hline MT - 20 & $T-10$ & NRC & TPM & 17.92210 & \\
\hline$M T-21$ & $T-10$ & NRC & TPM & 12.17838 & \\
\hline MT -22 & $T-11$ & NRC & TPM & 2.621411 & . \\
\hline$M T-23$ & $T-12$ & NRC & TPM & 10.47821 & \\
\hline$M T-24$ & $T-12$ & NRC & TPM & 7.341926 & \\
\hline$M T-25$ & $T-13$ & NRC & TPM & 2.928129 & \\
\hline$M T-26$ & $T-14$ & NRC & TPM & 7.111910 & \\
\hline$M T-27$ & $T-14$ & NRC & TPM & 10.43029 & \\
\hline$M T-28$ & $T-15$ & NRC & TPM & 2.715806 & \\
\hline$M T-29$ & $T-16$ & NRC & TPM & 12.40382 & \\
\hline$M T-30$ & $T-26$ & NRC & TPM & 18.45983 & \\
\hline$M T-31$ & $T-17$ & NRC & TPM & 19.72946 & \\
\hline$M T-32$ & $T-18$ & NRC & TPM & 37.68369 & \\
\hline$M T-33$ & $T-18$ & NRC & TPM & 17.91838 & \\
\hline MTC-1 & 19 & NRC & TPM & 15.20207 & 14.62922 \\
\hline 72.46995 & & & & ' & \\
\hline $\begin{array}{c}\text { MTC-1 } \\
59.72874\end{array}$ & 30 & NRC & TPM & 15.20207 & 14.62922 \\
\hline $\begin{array}{c}\text { MTC-2 } \\
71.77422\end{array}$ & 20 & NRC & TPM & 12.35846 & 16.82090 \\
\hline $\begin{array}{c}\text { MTC-2 } \\
59.72874\end{array}$ & 30 & NRC & TPM & 12.35846 & 16.82090 \\
\hline $\begin{array}{c}\text { MTC-11 } \\
209.2419\end{array}$ & 419 & NRC & TPM & 13.10440 & 43.72967 \\
\hline MTC-11 & 430 & $\mathrm{NRC}$ & TPM & 13.10440 & 43.72967 \\
\hline 170.2917 & & & & & . \\
\hline
\end{tabular}



Attachment D: $\frac{\text { REDOX (Corrected Coordinates in "GT Strudl" Model) Output for Seismic Analysis }}{\text { (Using Original Ground Response Spectrum for 10\% Damping) }}$

\begin{tabular}{|c|c|c|c|c|c|}
\hline $\begin{array}{c}\text { MTC }-12 \\
173.5191\end{array}$ & 420 & NRC & TPM & 38.76161 & 4.702535 \\
\hline $\begin{array}{c}\text { MTC-12 } \\
170.1299\end{array}$ & 430 & NRC & $T P M$ & 38.76161 & 4.702535 \\
\hline $\begin{array}{c}\text { MTC-13 } \\
3.707520\end{array}$ & 430 & $\mathrm{NRC}$ & TPM & 17.94607 & 6.844652 \\
\hline $\begin{array}{c}\text { MTC-13 } \\
0.3612327 E\end{array}$ & $\begin{array}{r}T-7 \\
E-06\end{array}$ & NRC & TPM & 17.94607 & 6.844652 \\
\hline MRS-1 & RS-1 & NRC & TPM & 22.63780 & \\
\hline MTC-3 & $T-1$ & NRC & TPM & 23.88249 & \\
\hline $\begin{array}{l}\text { MRS-2 } \\
0.3562712 \mathrm{E}\end{array}$ & $\begin{array}{l}\text { RS-1 } \\
\text { E-07 }\end{array}$ & NRC & TPM & 0.3450047 & 22.66289 \\
\hline $\begin{array}{l}\text { MRS-2 } \\
16.99717\end{array}$ & RS-2 & NRC & TPM & 0.3450047 & 22.66289 \\
\hline $\begin{array}{l}\text { MRS-3 } \\
16.99717\end{array}$ & RS-2 & NRC & TPM & 2.654543 & 1.727326 \\
\hline $\begin{array}{l}\text { MRS-3 } \\
8.942825\end{array}$ & RS-3 & NRC & TPM & 2.654543 & 1.727326 \\
\hline $\begin{array}{l}\text { MRS-4 } \\
8.942830\end{array}$ & RS - 3 & NRC & TPM & 6.749925 & 1.091538 \\
\hline $\begin{array}{l}\text { MRS-4 } \\
4.032241\end{array}$ & RS-4 & NRC & TPM & 6.749925 & 1.091538 \\
\hline $\begin{array}{l}\text { MRS-5 } \\
4.032245\end{array}$ & RS-4 & NRC & TPM & 10.81723 & 1.718182 \\
\hline $\begin{array}{l}\text { MRS-5 } \\
14.43072\end{array}$ & RS- 5 & NRC & TPM & 10.81723 & 1.718182 \\
\hline $\begin{array}{l}\text { MRS- } 6 \\
14.43072\end{array}$ & RS-5 & NRC & TPM & 14.88359 & 0.6178546 \\
\hline $\begin{array}{l}\text { MRS-6 } \\
12.11731\end{array}$ & RS- 6 & NRC & TPM & 14.88359 & 0.6178546 \\
\hline $\begin{array}{l}\text { MRS-7 } \\
12.11731\end{array}$ & RS- 6 & NRC & TPM & 18.94862 & 1.138842 \\
\hline $\begin{array}{l}\text { MRS-7 } \\
16.79025\end{array}$ & RS-7 & NRC & TPM & 18.94862 & 1.138842 \\
\hline $\begin{array}{l}\text { MRS-8 } \\
16.79025\end{array}$ & RS -7 & NRC & TPM & 23.01200 & 1.139786 \\
\hline $\begin{array}{l}\text { MRS-8 } \\
13.69452\end{array}$ & RS- 8 & NRC & TPM & 23.01200 & 1.139786 \\
\hline
\end{tabular}

\section{Sheet D33 of D35}

ATTTACHMENT-D: Calc. No. 0200W-CA-C0156 Rev. No. 0 Job No. 22192 
BHI-01299

Rev. 0

Attachment D: REDOX (Corrected Coordinates in "GT Strudl" Model) Output for Seismic Analysis (Using Original Ground Response Spectrum for 10\% Damping)

\begin{tabular}{|c|c|c|c|c|c|}
\hline $\begin{array}{c}\text { MRS - } 9 \\
13.69453\end{array}$ & RS-8 & $\mathrm{NRC}$ & $\mathrm{TPM}$ & 27.07335 & 0.8768210 \\
\hline $\begin{array}{c}\text { MRS-9 } \\
14.31470\end{array}$ & RS-9 & NRC & TPM & 27.07335 & 0.8768210 \\
\hline $\begin{array}{c}\text { MRS }-10 \\
14.31469\end{array}$ & RS - 9 & NRC & TPM & 31.13233 & 2.262422 \\
\hline $\begin{array}{c}\text { MRS-10 } \\
8.628003\end{array}$ & RS-10 & NRC & TPM & 31.13233 & 2.262422 \\
\hline $\begin{array}{c}\text { MRS-11 } \\
8.628000\end{array}$ & RS-10 & NRC & TPM & 35.18861 & 8.236533 \\
\hline $\begin{array}{c}\text { MRS - 11 } \\
43.92697\end{array}$ & RS-11 & NRC & TPM & 35.18861 & 8.236533 \\
\hline $\begin{array}{c}\text { MRS }-12 \\
43.92697\end{array}$ & RS-11 & NRC & TPM & 39.26922 & 27.32346 \\
\hline $\begin{array}{c}\text { MRS-12 } \\
214.1840\end{array}$ & RS-12 & NRC & TPM & 39.26922 & 27.32346 \\
\hline $\begin{array}{c}\text { MRS - } 13 \\
214.1840\end{array}$ & RS-12 & NRC & TPM & 41.56732 & 14.86203 \\
\hline $\begin{array}{c}\text { MRS-13 } \\
224.8905\end{array}$ & RS-13 & NRC & TPM & 41.56732 & 14.86203 \\
\hline $\begin{array}{c}\text { MRS-14 } \\
224.8905\end{array}$ & RS-13 & NRC & TPM & 14.86375 & 41.89764 \\
\hline $\begin{array}{c}\text { MRS-16 } \\
211.0225\end{array}$ & 422 & NRC & TPM & 14.86375 & 41.89764 \\
\hline MTRS-1 & $\mathrm{RS}-2$ & NRC & TPM & 24.32860 & \\
\hline MTRS-2 & RS-3 & NRC & TPM & 1.911050 & \\
\hline MTRS-3 & RS-4 & NRC & TPM & 5.766903 & \\
\hline MTRS-4 & RS -5 & NRC & TPM & 2.522465 & \\
\hline MTRS-5 & RS-6 & NRC & TPM & 5.341441 & \\
\hline MTRS- 6 & RS-7 & NRC & TPM & 2.817596 & \\
\hline MTRS-7 & RS- 8 & NRC & TPM & 5.309811 & \\
\hline MTRS-8 & RS-9 & NRC & TPM & 2.623156 & \\
\hline MTRS-9 & $\mathrm{RS}-10$ & NRC & TPM & 11.57690 & \\
\hline MTRS-10 & RS-11 & NRC & TPM & 19.71387 & \\
\hline
\end{tabular}

ATTTACHMENT-D: Calc. No. $0200 W-C A-C 0156$ Rev. No. 0 job No. 22192 
BHI-01299

Rev. 0

Attachment D: REDOX (Corrected Coordinates in "GT Strud" Model) Output for Seismic Analysis (Using Original Ground Response Spectrum for $10 \%$ Damping)

MTRS-11
$\{455\}>$
$\{456\}>$
$\{457\}>$
$\{458\}>$
$\{459\}>$

ATTTACHMENT-D: Calc. No. 0200W-CA-C0156 Rev. No. 0 Job No. 22192 
BHI-01299

Rev. 0

$\therefore$

A-122 
BHI-01299

Rev. 0

ATTACHMENT:

E

ORIGINATOR:

R. S. Rajagopal St

DATE: August 19, 1999

CHECKED BY:

0200W-CA-C0156

DATE: $\quad \pi / \& / 99$

CALC. NO. OF TOTAL REV. NO.

0

SHEET NO. E OF TOTAL

10 SHEETS

\section{ATTACHMENT "E"}

REDOX (Corrected Coordinates in "GT Strudl" Model) Input for Seismic Analysis (Using Ground Response Spectrum for "Existing PC3 Structures"-10\% Damping) 
BHI-01299

Rev. 0

Attachment E: REDOX (Corrected Coordinate in "GT Strud" Model) Input for Seismic Analysis (Using Ground Response Spectrum for "Existing PC3 Structures"- 10\% Damping)

STRUDL 'REDOX BUILDING' ' 2 -D ANALYSTS OF TYPICAL SLICE'

$\$ \$$

$\$ \$$ TRUSS CONNECTED TO BUILDING BY SP $\mathrm{K}=136 \mathrm{kIP} / \mathrm{IN}$

$\$ \$$ AT ONE END. SLOTTED HOLE END FREE

UNITS INCH KIPS DEGREES FAH

$\$ \$$

JOINT COORDINATES GLOBAL

$\$ \$$ SOUTH WALL

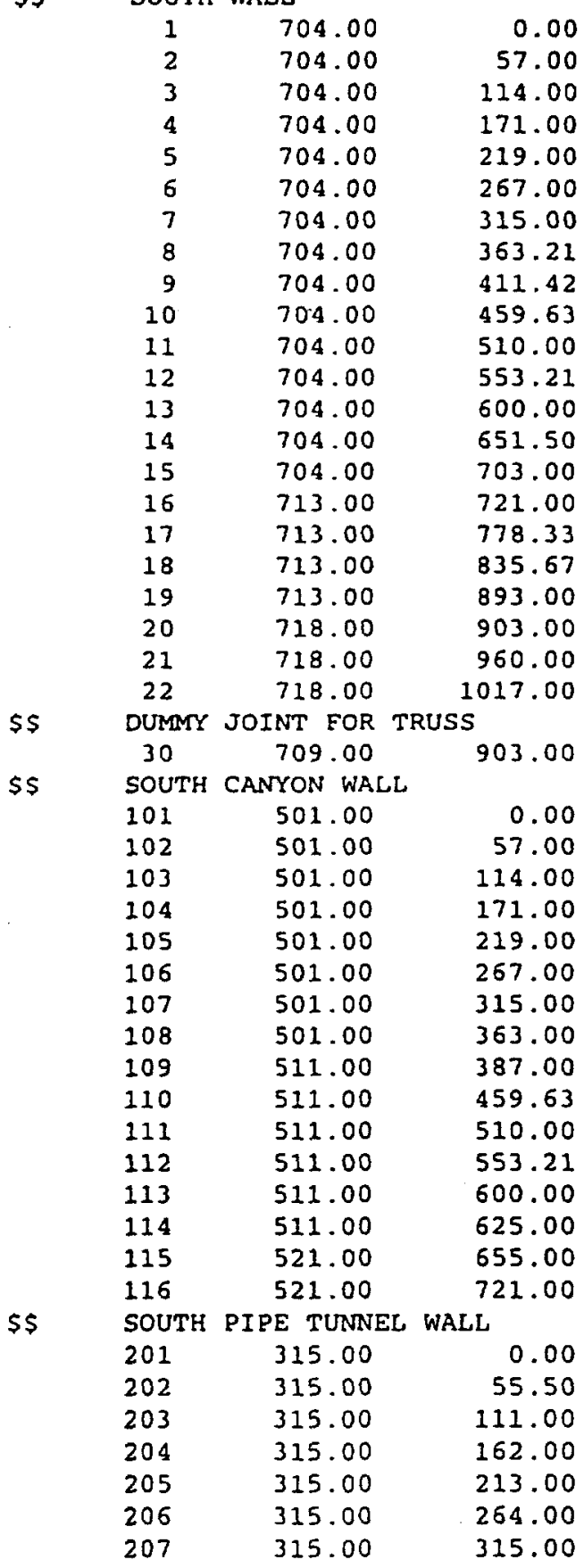

Sheet E2 of E10

ATTTACHMENT-E: Calc. No. $0200 W-C A-C 0156$ Rev. No. 0 Job No. 22192 
Attachment E: REDOX (Corrected Coordinate in "GT Strudl" Model) Input for Seismic Analysis (Using Ground Response Spectrum for "Existing PC3 Structures"- 10\% Damping)

\begin{tabular}{llr}
208 & 267.00 & \multicolumn{1}{c}{363.00} \\
NORTH & PIPE TUNNEL & WALL \\
301 & 183.00 & 0.00 \\
302 & 183.00 & 55.50 \\
303 & 183.00 & 111.00 \\
304 & 183.00 & 162.00 \\
305 & 183.00 & 213.00 \\
306 & 183.00 & 264.00 \\
307 & 183.00 & 315.00 \\
308 & 231.00 & 363.00 \\
$\$ \$ 4$ & & \\
4 & CANTH & \\
401 & 0.00 & 0.00 \\
402 & 0.00 & 57.00 \\
403 & 0.00 & 114.00 \\
404 & 0.00 & 171.00 \\
405 & 0.00 & 219.00 \\
406 & 0.00 & 267.00 \\
407 & 0.00 & 315.00 \\
408 & 0.00 & 363.00 \\
409 & -28.00 & 403.00 \\
410 & -28.00 & 459.00 \\
411 & -28.00 & 513.75 \\
412 & -28.00 & 568.50 \\
413 & -28.00 & 623.25 \\
414 & -28.00 & 678.00 \\
415 & -28.00 & 703.00 \\
416 & -37.00 & 721.00 \\
417 & -37.00 & 778.00 \\
418 & -37.00 & 835.67 \\
419 & -37.00 & 893.00 \\
420 & -42.00 & 903.00 \\
421 & -42.00 & 960.00 \\
422 & -42.00 & 1017.00
\end{tabular}

$\$ \$$ DUMMY JOINT FOR TRUSS CONNECTION

$\$ \$$ NORTH GALLERY WALL

$502 \quad-274.00 \quad 57.25$

$503 \quad-274.00 \quad 114.13$

$504 \quad-274.00 \quad 171.00$

$505 \quad-274.00 \quad 219.00$

$506 \quad-274.00 \quad 267.00$

$507 \quad-274.00 \quad 315.00$

$508 \quad-274.00 \quad 363.00$

$509 \quad-274.00 \quad 411.00$

$510 \quad-274.00 \quad 459.00$

$511 \quad-274.00 \quad 513.75$

$512 \quad-274.00 \quad 568.50$

$513 \quad-274.00 \quad 623.25$

$514 \quad-274.00 \quad 678.00$

\$\$ SLAB SI SOUTH GALLERY

$\begin{array}{lll} & S 1-1 & \end{array}$

'S1-2' $636.33 \quad 171.00$

$\$ \$$ SLAB S2 S SOUTH GALLERY

'S2-1' $\quad 568.67 \quad 315.00$

'S2-2. $636.33 \quad 315.00$

$\$ \$$ SLAB 53 a SOUTH GALLERY

$\begin{array}{lll}S 3-1 . & 568.67 & 459.63\end{array}$

Sheet E3 of E10

ATTTACHMENT-E: Calc. No. 0200W-CA-C0156 Rev. No. 0 Job No. 22192 
Rev. 0

Attachment E: REDOX (Corrected Coordinate in "GT Strudl" Model) Input for Seismic Analysis (Using Ground Response Spectrum for "Existing PC3 Structures"- 10\% Damping)

\begin{tabular}{|c|c|c|c|c|}
\hline \multicolumn{3}{|c|}{ ' $53-2$ ' } & 636.33 & 459.63 \\
\hline \multirow[t]{3}{*}{5} & SLAB & 54 & \multicolumn{2}{|c|}{ (a SOUTH GALLERY } \\
\hline & \multicolumn{2}{|l|}{ '54-1' } & \multicolumn{2}{|c|}{$568.67 \quad 600$} \\
\hline & \multicolumn{2}{|l|}{$' 54-2$ ' } & \multicolumn{2}{|l|}{636.33} \\
\hline \multirow[t]{3}{*}{$\$ \$$} & \multirow{2}{*}{\multicolumn{2}{|c|}{ ' $55-1 \cdot$}} & \multicolumn{2}{|c|}{ (2 NORTH GALLERY } \\
\hline & & & \multicolumn{2}{|c|}{-91.33} \\
\hline & \multicolumn{2}{|l|}{$' 55-2$ ' } & \multicolumn{2}{|l|}{-182.67} \\
\hline \multirow[t]{3}{*}{$\$ \$$} & SLAB & 56 & \multicolumn{2}{|c|}{ ( NORTH GALLERY } \\
\hline & \multicolumn{2}{|c|}{ 's6-1' } & -91.33 & 315.00 \\
\hline & \multicolumn{2}{|l|}{ 's6-2' } & \multicolumn{2}{|l|}{-182.67} \\
\hline \multirow[t]{3}{*}{$\$ \$$} & $S L A B$ & 57 & e NORTH G & GALLERY \\
\hline & 's7-1' & & -91.33 & 459.00 \\
\hline & 's7-2' & & -182.67 & 459.00 \\
\hline$\$$ & SLAB & 58 & a NORTH G & GALLERY \\
\hline & '58-1' & & -91.33 & 678.00 \\
\hline & ' $58-2$ ' & & -182.67 & 678.00 \\
\hline & $S L A B$ & s9 & e PIPE TU & UNNEL \\
\hline & ' $59-1$. & & 249.00 & 111.00 \\
\hline & ROOF & TRUS & ISS BOTTOM & M CHORD \\
\hline & $\cdot \mathrm{T}-1 \cdot$ & & 709.00 & 909.50 \\
\hline & $\cdot T-2 \cdot$ & & 634.00 & 909.50 \\
\hline & $\cdot \mathrm{T}-3 \cdot$ & & 486.00 & 909.50 \\
\hline & ' $T-4$ ' & & 338.00 & 909.50 \\
\hline & $\cdot T-5$ ' & & 190.00 & 909.50 \\
\hline & $\cdot T-6^{\prime}$ & & 42.00 & 909.50 \\
\hline & $' T-7$ ' & & -33.00 & 909.50 \\
\hline & $\cdot T-8 \cdot$ & & 709.00 & 1003.50 \\
\hline & 'T-9' & & 634.00 & 1003.50 \\
\hline & $\mathrm{T}-10^{\prime}$ & & 560.00 & 1003.50 \\
\hline & $\cdot T-11$ ' & & 486.00 & 1003.50 \\
\hline & $\cdot \mathrm{T}-12$ & & 412.00 & 1003.50 \\
\hline & $' \mathrm{~T}-13^{\prime}$ & & 338.00 & 1003.50 \\
\hline & $' \mathrm{~T}-14^{\prime}$ & & 264.00 & 1003.50 \\
\hline & $\cdot T-15^{\prime}$ & & 190.00 & 1003.50 \\
\hline & $\mathrm{T}-16^{\circ}$ & & 116.00 & 1003.50 \\
\hline & $. \mathrm{T}-17^{\prime}$ & & 42.00 & 003.50 \\
\hline & $' T-18^{\prime}$ & & -33.00 & 1003.50 \\
\hline & ROO & SL & & \\
\hline & 'RS-1' & & 718.00 & 021.00 \\
\hline & 'RS-2' & & 709.00 & 1021.00 \\
\hline & 'RS-3' & & 634.00 & 1021.00 \\
\hline & 'RS-4' & & 560.00 & 1021.00 \\
\hline & 'RS - 5' & & 486.00 & 1021.00 \\
\hline & 'RS-6' & & 412.00 & 1021.00 \\
\hline & 'RS-7' & & 338.00 & 1021.00 \\
\hline & 'RS-8' & & 264.00 & 1021.00 \\
\hline & 'RS-9' & & 190.00 & 1021.00 \\
\hline & RS-10' & & 116.00 & 1021.00 \\
\hline & RS-11 & & 42.00 & 1021.00 \\
\hline & RS $-12^{\circ}$ & & -33.00 & 1021.00 \\
\hline & $R S-13^{\prime}$ & & -42.00 & 1021.00 \\
\hline
\end{tabular}

$\$ \$$

TYPE PLANE FRAME

$\$ \$$ MEMBER FOR SOUTH GALLERY WALL MEMBER INCIDENCES

121

GENERATE 20 MEMBERS ID 2 FROM 2 INC 1 TO 3 INC 1

Sheet E4 of E10

ATTTACHMENT-E: Calc. No. 0200 W-CA-C0156 Rev. No. 0 Job No. 22192 
BHI-01299

Rev. 0

Attachment E: REDOX (Corrected Coordinate in "GT Strudl" Model) Input for Seismic Analysis

(Using Ground Response Spectrum for "Existing PC3 Structures"- 10\% Damping)

\$\$ MEMBER FOR SOUTH CANYON WALL

MEMBER INCIDENCES

$101 \quad 101 \quad 102$

GENERATE 14 MEMBERS ID 102 FROM 102 INC 1 TO 103 INC 1

$\$ \$$ MEMBER FOR SOUTH PIPE TUNNEL WALL

MEMBER INCIDENCES

$$
201201202
$$

GENERATE 6 MEMBERS ID 202 FROM 202 INC 1 TO 203 INC 1

$\$ \$$ MEMBER FOR NORTH PIPE TUNNEL WALL

MEMBER INCIDENCES

$301 \quad 301 \quad 302$

GENERATE 6 MEMBERS ID 302 FROM 302 INC 1 TO 303 INC 1

\$\$ MEMBER FOR NORTH CANYON WALL

MEMBER INCIDENCES

$401401 \quad 402$

GENERATE 20 MEMBERS ID 402 FROM 402 INC 1 TO 403 INC 1

$\$ \$$ MEMBER FOR NORTH GALLERY WALL

MEMBER INCIDENCES

$502 \quad 502 \quad 503$

GENERATE 11 MEMBERS ID 503 FROM 503 INC 1 TO 504 INC 1

MEMBER INCIDENCES

\$\$ SLAB \& $88^{\circ}$ SOUTH GALLERY

'MS1-1' 104 'S1-1'

MS1-2. 'sl-1. 's1-2.

'MS1-3' 'S1-2' 4

$\$ \$$ SLAB E $100^{\circ}$ SOUTH GALLERY

MS2 - ${ }^{\circ} \quad 107$ 'S2-1.

'MS2-2' 's2-1. 's2-2.

'MS2-3' $\cdot S 2-2$ ' 7

\$\$ SLAB a $112^{\prime} 11 / 4^{*}$ SOUTH GALLERY

'MS3-1. $110 \quad$ 'S3-1'

MS3-2' 's3-1' $53-2$ '

'MS3-3' 'S3-2. 10

$\$ \$$ SLAB $124^{\circ}$ SOUTH GALLERY

'MS4-1. 113 'S4-1.

'MS4-2' 'S4-1' 'S4-2'

'MS4-3' 'S4-2' 13

S\$ SLAB 83' NORTH GALLERY

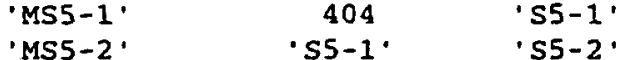

'MS5-3' 'SS-2' 504

$\$ \$$ SLAB $100^{\circ}$ NORTH GALLERY

'MSG-1' 407 'S6-1'

'MS6-2' 'S6-1' 'S6-2'

'MS6-3' 'S6-2' 507

$\$ \$$ SLAB $112^{\circ}$ NORTH GALLERY

'MS7-1. 410 'S7-1.

'MS7-2' 'S7-1' 'S7-2'

'MS7-3' 'S7-2' 510

\$ SLAB 130' 6" NORTH GALLERY

'MS8-1' 414 'SB-1'

'MS8-2. 'SB-1' 'S8-2.

'MS8-3' $S 8-2^{\circ} \quad 514$

\$\$ SLAB \& 83, PIPE TUNNEL 303 ' $59-1$ '

'MS9-2' 'S9-1' 203

\$ PIPE TUNNEL ROOF $105^{\prime} 6^{\prime}$

Sheet E5 of E10

ATTTACHMENT-E: Calc. No. 0200W-CA-C0156 Rev. No. 0 Job No. 22192 
BHI-01299

Rev. 0

Attachment E: REDOX (Corrected Coordinate in "GT Strudl" Model) Input for Seismic Analysis (Using Ground Response Spectrum for "Existing PC3 Structures"- 10\% Damping) 'MTR-1. $\quad 308 \quad 208$

$\$ \$$

TYPE PLANE TRUSS

MEMBER INCIDENCES

\$\$ COVERS ON CELL

$\begin{array}{lll}\text { CC }-1 ' & 208 & 108 \\ . \mathrm{CC}-2 & 408\end{array}$

$\$ \$$ TRUSS MEMBERS BOTTOM CHORD 'MT-1' 'T-1' 'T-2'

GENERATE 5 MEMBERS ID 'MT-2' INC 1 FROM 'T-2' INC 1 TO ' $\mathfrak{r}-3$ ' INC 1 \$\$ TRUSS MEMBERS TOP CHORD

MEMBER INCIDENCES 'MT-7' $T$ ' $\mathrm{T}-8$ ' $\mathrm{T}-9$ '

GENERATE 9 MEMBERS ID 'MT-8' INC 1 FROM 'T-9' INC 1 TO 'T-10' INC 1 $\$ \$$ TRUSS MEMBERS DIAGONALS AND VERTICALS MEMBER INCIDENCES

\begin{tabular}{|c|c|c|}
\hline 'MT-17' & $\cdot T-1$. & ' $T-8$ ' \\
\hline ' $M T-18$ ' & $\cdot T-2$ ' & $\cdot T-8$ ' \\
\hline ' MT- $19^{\circ}$ & ' $T-2$ ' & $\cdot \mathrm{T}-9$ ' \\
\hline ' $M T-20$ ' & ' $T-2$ ' & ' $T-10^{\circ}$ \\
\hline - $M T-21$ ' & $=T-3$. & $\cdot T-10^{\prime}$ \\
\hline ' $\mathrm{MT}-22$ ' & $T-3$ ' & $T-11$ \\
\hline ' $\mathrm{MT}-23^{\prime}$ & $T-3$. & 'T-12' \\
\hline MT-24 & ' $T-4$ ' & 'T-12' \\
\hline ' $M T-25^{\circ}$ & $\cdot T-4$. & $\cdot T-13$ ' \\
\hline ' $M T-26^{\prime}$ & $T-4$. & ' $\mathrm{T}-14$ ' \\
\hline$M-27$ ' & $\cdot T-5$. & ' $T-14^{\prime}$ \\
\hline 'MT-28' & $=T-5$. & ' $T-15$ ' \\
\hline$M T-29^{\circ}$ & $=T-5$ & ' $T-16$ ' \\
\hline$M T-30^{\circ}$ & $\cdot T-6$. & - $T-16$ \\
\hline ' $M T-31$ ' & - $T-\sigma^{\circ}$ & $=\mathrm{T}-17$. \\
\hline 'MT-32' & $\cdot \mathrm{T}-6^{\prime}$ & $\cdot T-18$ ' \\
\hline$\cdot M T-33^{\circ}$ & $\mathrm{T}-7$ & ' $T-18$ ' \\
\hline
\end{tabular}

$\$ \$$

TYPE PLANE FRAME

MEMBER INCIDENCES

S\$ CONNECTION TO BUILDING STRUCTURE SOUTH SIDE 'MTC-1. $19 \quad 30$ 'MTC-2' $20 \quad 30$

\$\$ 'MTC-3' MODALLED AS TRUSS MEM - NO LATERAL TRANSFER

$\$ \$$ CONNECTION TO BUILIDING STRUCTURE NORTH SIDE

'MTC-11' $419 \quad 430$

'MTC-12' 420

$\$ \$$

'MTC-13' $430 \quad$ 'T-7'

TYPE PLANE TRUSS

MEMBER INCIDENCES

\$\$ ROOF SLAB MEMBER 'MRS-1' 22 'RS-1'

\$\$ CONNECTION BETWEEN TRUSS AND BUILDING - AXIAL LOAD ONLY ' $M T C-3{ }^{\circ} \quad 30 \quad$ 'T-1'

$\$ \$$

TYPE PLANE FRAME

MEMBER INCIDENCES

'MRS-2' 'RS-1' 'RS-2'

GENERATE 11 MEMBERS ID 'MRS-3' INC 1 FROM 'RS-2' INC 1 TO 'RS-3' INC 1 MEMBER INCIDENCES

ATTTACHMENT-E: Calc. No. 0200W-CA-C0156 Rev. No. 0 Job No. 22192 
Attachment E: REDOX (Corrected Coordinate in "GT Strudl" Model) Input for Seismic Analysis (Using Ground Response Spectrum for "Existing PC3 Structures"- 10\% Damping)

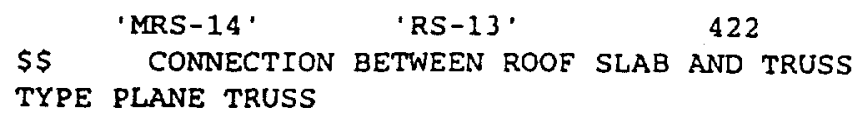


\$\$ NORTH CANYON WALL EROM CRANE LEVEL TO TRUSS SUPPORT

MEMBER PROPERTIES PRISMATIC

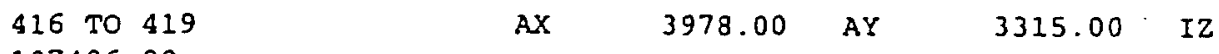

107406.00

\$\$ NORTH CANYON WALL FROM TRUSS SUPPORT TO ROOF

MEMBER PROPERTIES PRISMATIC

$\begin{array}{llllll}420421 & \text { AX } & 1768.00 & \text { AY } & 1473.00 & \text { IZ } \\ 9429.00 & & & & \\ \$ \$ \$ \text { NORTH GALLERY WALL } & & & & \\ \text { MEMBER PROPERTIES PRISMATIC } & & & & \\ 502 \text { TO } 513 & \text { AX } & 5304.00 & \text { AY } & 4420.00 & \text { IZ } \\ 95472.00 & & & & \end{array}$

$\$ \$ \quad 1$ ' THICK SLAB

MEMBER PROPERTIES PRISMATIC

'MS1-1' TO 'MS1-3' 'MS2-1' TO 'MS2 -3' 'MS3-1' TO 'MS3-3' -

'MSS-1' TO 'MSS-3' 'MS6-1' TO 'MS6-3' 'MS7-1' TO 'MS7-3' -

'MS9-1' TO 'MS9-2' AX 2652.00 AY 2210.00 IZ

31824.00

\$\$ 1.6" THICK SLAB

MEMBER PROPERTIES PRISMATIC

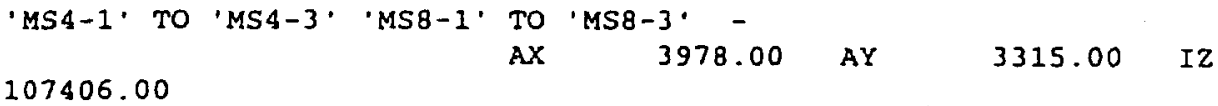

107406.00

$\$ \$$ ROOF SLAB

MEMBER PROPERTIES PRISMATIC

'MRS-2 ${ }^{\circ}$ TO 'MRS-13' AX 1989.00 AY $1658.00 \quad$ IZ

13425.00

$\$ \$$ TRUSS CONNECTION TO STRUCTURE

MEMBER PROPERTIES PRISMATIC

'MTC-1' TO 'MTC-2' 'MTC-11' TO 'MTC-12' -

859248.00

AX $\quad 7956.00 \quad$ AY $\quad 6630.00 \quad$ IZ

SS REDUCED STIFFNESS FOR CONNECTION TO TRUSS

MEMBER PRORERTIES PRISMATIC

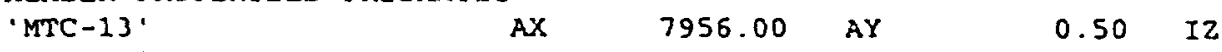

859248.00

$\$ \$$ COVER FOR CELLS

MEMBER PROPERTIES PRISMATIC

'CC-1' ${ }^{\circ} \mathrm{CC}-2^{\prime}$ AX 10608.00

$\$ \$$ CONN BET TRUSS \& BLDG - TRUSS MEM \& SOUTH END

MEMBER PROPERTIES PRISMATIC

'MTC-3' AX 7956.00

\$\$ TRUSS MEMBER

MEMBER PROPERTIES PRISMATIC

'MT-1' TO 'MT-16' AX

MEMBER PROPERTIES PRISMATIC

'MT-17' 'MT-33' AX

MEMBER PROPERTIES PRISMATIC

'MT-19' 'MT-31' AX

MEMBER PROPERTIES PRISMATIC

'MT-22' 'MT-28' AX

MEMBER PROPERTIES PRISMATIC

'MT-25' AX

MEMBER PROPERTIES PRISMATIC

'MT-18' 'MT-32' AX

MEMBER PROPERTIES PRISMATIC

'MT-20' 'MT-30' AX

12.86

4.80

3.56

3.56

7.12

AX 8.00

Ax 6.62

ATTTACHMENT-E: Calc. No. $0200 W-C A-C 0156$ Rev. No. 0 Job No. 22192 
BHI-01299

Rev. 0

Attachment E: REDOX (Corrected Coordinate in "GT Strudl" Model) Input for Seismic Analysis

(Using Ground Response Spectrum for "Existing PC3 Structures"- 10\% Damping)

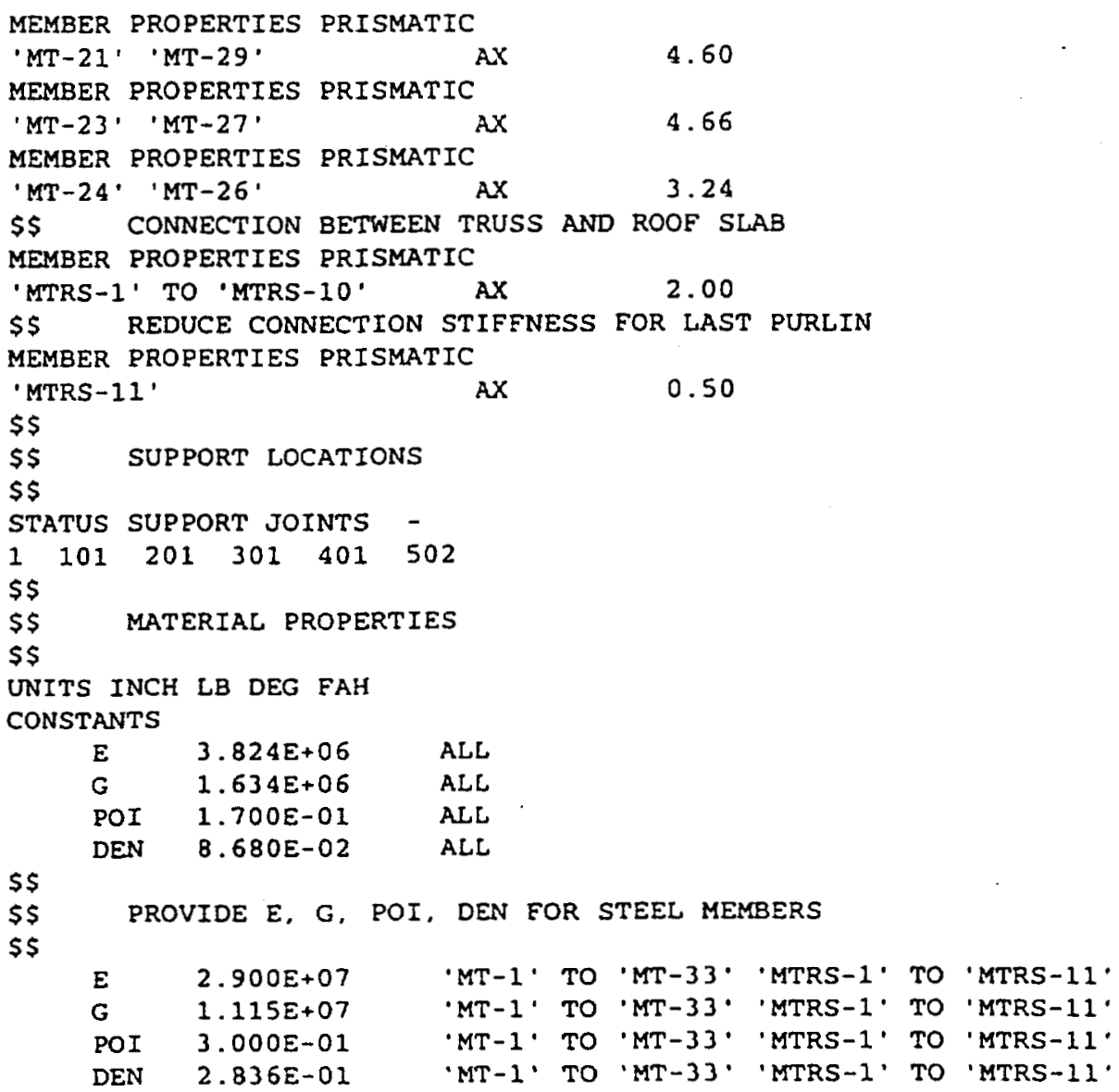

Sheet E9 of E10

ATTTACHMENT-E: Calc. No. 0200W-CA-C0156 Rev. No. 0 Job No. 22192 
BHI-01299

Rev. 0

Attachment E: REDOX (Corrected Coordinate in "GT Strudl" Model) Input for Seismic Analysis (Using Ground Response Spectrum for "Existing PC3 Structures"- 10\% Damping)

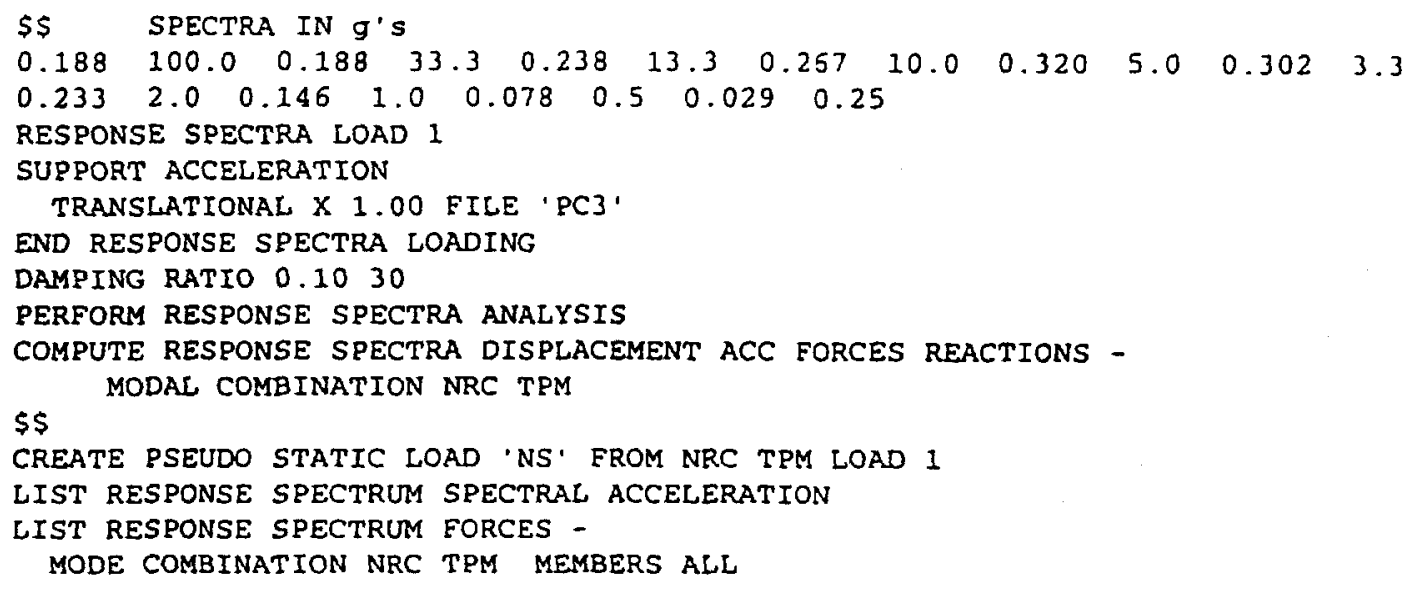


BHI-01299

Rev. 0

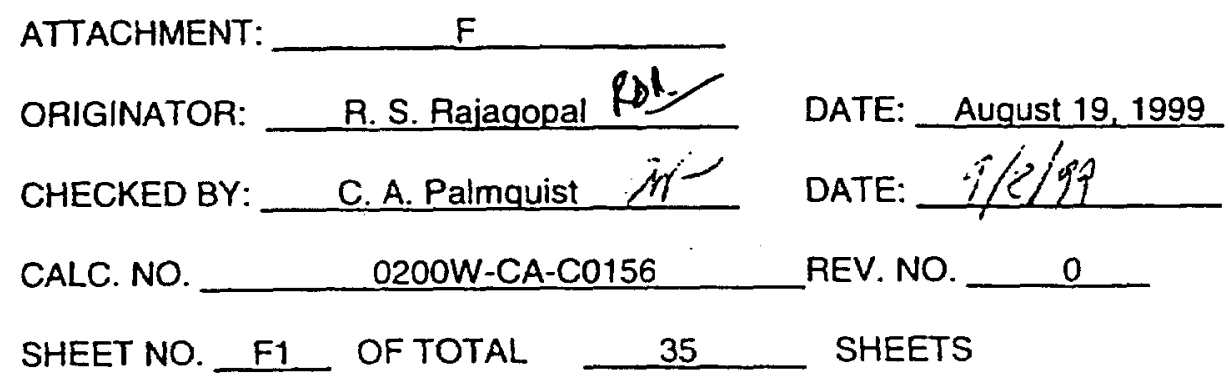

\section{ATTACHMENT "F"}

REDOX (Corrected Coordinates in "GT Strudl" Model) Output for Seismic Analysis (Using Ground Response Spectrum for "Existing PC3 Structures"-10\% Damping)

The governing output values used on sheet 13 are highlighted as " $\longleftarrow$ " in the following output. 
Attachment F: REDOX (Corrected Coordinate in "GT Strudl" Model) Output for Seismic Analysis

Any use, duplication or disclosure of this software by or for the U.S. Government shall be restricted to the terms of a license agreement in accordance with the clause at DFARS 227.7202-3.

This computer software is an unpublished work containing valuable trade secrets owned by the Georgia Tech Research Corporation (GTRC). No access, use, transfer. duplication or disclosure thereof may be made except under a license agreement executed by GTRC or its authorized representatives and no right, ticle or interest thereto is conveyed or granted herein. notwithstanding receipt or possession hereof. Decompilation of the object code is strictly prohibited.

Georgia Tech Research Corporation

Georgia Institute of Technology

Atlanta, Georgia 30332 U.S.A.

Copyright (C) 1998 GTRC

ALL RIGHTS RESERVED.

\# Wed Jul $21 \quad 12: 37: 21 \quad 1999$

1GTICES/C-NP 2.5.0 MD-NT 2.0, January 1995.

Proprietary to Georgia Tech Research Corporation, U.S.A.

Reading password file C: IProgram Files/GTSTRUd 9801 Igtaccess.dat CI-i-audfile. Command AUDIT file EILE1237, aud has been activated.

* G T S T R U D L ** RELEASE DATE VERSION March $1998 \quad 9801$ NT COMPLETION NO. 3716

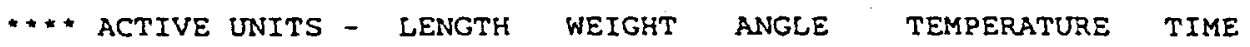
** ASSUMED TO BE INCH POUND RADIAN FAHRENHEIT SECOND

Reading global defaults file C: \Program Files/GTSTRUDL 9801\defaults.gts

( 1$)>\$$ put any startup commands in this file

(1) 1 1

$\{2\}>$ CINPUT 'C: $\backslash$ Hanford 2 Redox_7.inp'

( 3$)>$ STRUDL 'REDOX BUILDING' '2-D ANALYSIS OF TYPICAL SLICE'

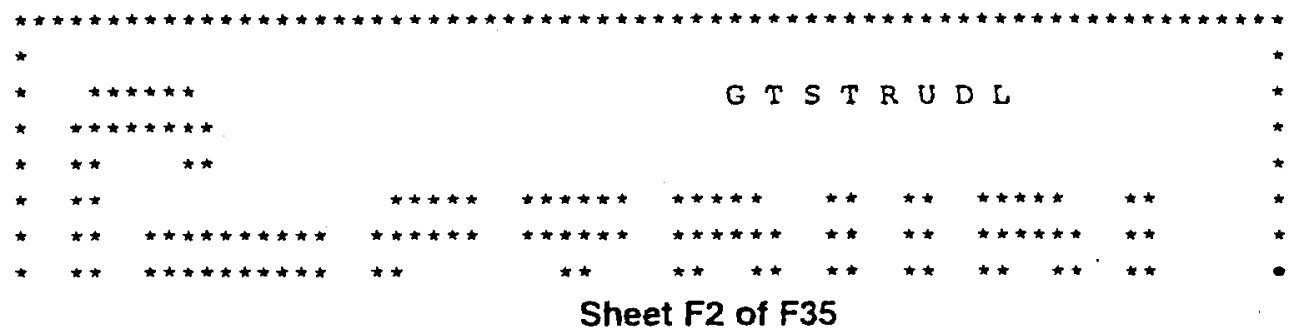

ATTTACHMENT-F: Calc. No. $0200 W-C A-C 0156$ Rev. No. 0 Job No. 22192 
Attachment F: REDOX (Corrected Coordinate in "GT Strudl" Model) Output for Seismic Analysis (Using Ground Response Spectrum for "Existing PC3 Structures"- 10\% Damping)
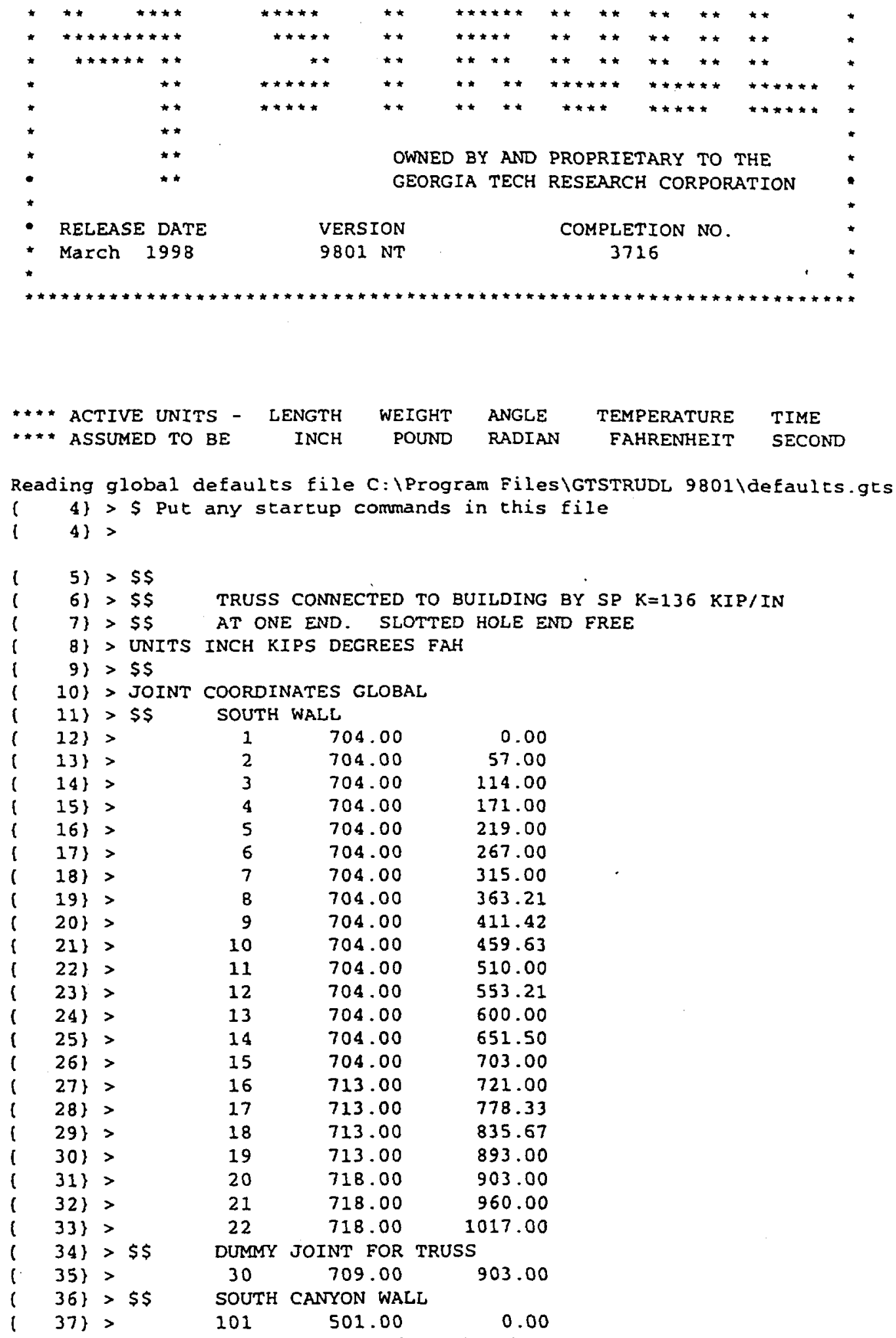

ATTTACHMENT-F: Calc. No. D200W-CA-C0156 Rev. No. 0 Job No. 22192 


\begin{tabular}{|c|c|c|c|c|}
\hline 38$\}$ & $>$ & 102 & 501.00 & 57.00 \\
\hline 39$\}$ & $>$ & 103 & 501.00 & 114.00 \\
\hline 40$\}$ & $>$ & 104 & 501.00 & 171.00 \\
\hline 413 & $>$ & 105 & 501.00 & 219.00 \\
\hline 42$\}$ & $>$ & 106 & 501.00 & 267.00 \\
\hline 43) & $>$ & 107 & 501.00 & 315.00 \\
\hline 44) & $>$ & 108 & 501.00 & 363.00 \\
\hline 451 & $>$ & 109 & 511.00 & 387.00 \\
\hline 46$\}$ & $>$ & 110 & 511.00 & 459.63 \\
\hline 47\} & $>$ & 111 & 511.00 & 510.00 \\
\hline 48$)$ & $>$ & 112 & 511.00 & 553.21 \\
\hline 49\} & $>$ & 113 & 511.00 & 600.00 \\
\hline 50) & $>$ & 114 & 511.00 & 625.00 \\
\hline 51$\}$ & $>$ & 115 & 521.00 & 655.00 \\
\hline 52) & $>$ & 116 & 521.00 & 721.00 \\
\hline 53$\}$ & $>\$ \$$ & SOUTH & PIPE TUNNEL & WALL \\
\hline 541 & $>$ & 201 & 315.00 & 0.00 \\
\hline 55) & $>$ & 202 & 315.00 & 55.50 \\
\hline 56$\}$ & $>$ & 203 & 315.00 & 111.00 \\
\hline 571 & $>$ & 204 & 315.00 & 162.00 \\
\hline 58) & $>$ & 205 & 315.00 & 213.00 \\
\hline 59) & $>$ & 206 & 315.00 & 264.00 \\
\hline 60) & $>$ & 207 & 315.00 & 315.00 \\
\hline 61$\}$ & $>$ & 208 & 267.00 & 363.00 \\
\hline 62$\}$ & $>\$ \$$ & NORTH & PIPE TUNNEL & WALL \\
\hline 63) & $>$ & 301 & 183.00 & 0.00 \\
\hline 64$\}$ & $>$ & 302 & 183.00 & 55.50 \\
\hline 65$\}$ & $>$ & 303 & 183.00 & 111.00 \\
\hline 66) & $>$ & 304 & 183.00 & 162.00 \\
\hline 67$\}$ & $>$ & 305 & 183.00 & 213.00 \\
\hline 68$\}$ & $>$ & 306 & 183.00 & 264.00 \\
\hline 691 & $>$ & 307 & 183.00 & 315.00 \\
\hline 70$\}$ & $>$ & 308 & 231.00 & 363.00 \\
\hline 71$)$ & $>\$ \$$ & NORTH & CANYON WALL & \\
\hline 72$\}$ & $>$ & 401 & 0.00 & 0.00 \\
\hline 73) & $>$ & 402 & 0.00 & 57.00 \\
\hline 741 & $>$ & 403 & 0.00 & 114.00 \\
\hline 751 & $>$ & 404 & 0.00 & 171.00 \\
\hline 761 & $>$ & 405 & 0.00 & 219.00 \\
\hline 77) & $>$ & 406 & 0.00 & 267.00 \\
\hline 78$\}$ & $>$ & 407 & 0.00 & 315.00 \\
\hline 791 & $>$ & 408 & 0.00 & 363.00 \\
\hline 80$\}$ & $>$ & 409 & -28.00 & 403.00 \\
\hline 81$\}$ & $>$ & 410 & -28.00 & 459.00 \\
\hline 82\} & $>$ & 411 & -28.00 & 513.75 \\
\hline 83) & $>$ & 412 & -28.00 & 568.50 \\
\hline 84$\}$ & $>$ & 413 & -28.00 & 623.25 \\
\hline 85$\}$ & $>$ & 414 & -28.00 & 678.00 \\
\hline 86$\}$ & $>$ & 415 & -28.00 & 703.00 \\
\hline 87) & $>$ & 416 & -37.00 & 721.00 \\
\hline 88$\}$ & $>$ & 417 & -37.00 & 778.00 \\
\hline 89$\}$ & $>$ & 418 & -37.00 & 835.67 \\
\hline 90$\}$ & $>$ & 419 & -37.00 & 893.00 \\
\hline 91$\}$ & $>$ & 420 & -42.00 & 903.00 \\
\hline 92$\}$ & $>$ & 421 & -42.00 & 960.00 \\
\hline 93$\}$ & $>$ & 422 & -42.00 & 1017.00 \\
\hline 94$\}$ & $>\$ \$$ & DUMMY & OINT FOR & SS CONNE \\
\hline
\end{tabular}

ATTTACHMENT-F: Calc. No. 0200W-CA-C0156 Rev. No. 0 Job No. 22192 
Rev. 0

Attachment F: REDOX (Corrected Coordinate in "GT Strudl" Model) Output for Seismic Analysis (Using Ground Response Spectrum for "Existing PC3 Structures"- 10\% Damping)

\begin{tabular}{|c|c|c|c|c|}
\hline 95$\}$ & $>$ & 430 & -33.00 & 903.00 \\
\hline 96$\}$ & $>\$ \$$ & NORTH & H GALLERY WALL & \\
\hline 97\} & $>$ & 502 & -274.00 & 57.25 \\
\hline 981 & $>$ & 503 & -274.00 & 114.13 \\
\hline 99$\}$ & $>$ & 504 & -274.00 & 171.00 \\
\hline 100$\}$ & $>$ & 505 & -274.00 & 219.00 \\
\hline 101) & $>$ & 506 & -274.00 & 267.00 \\
\hline 102$\}$ & $>$ & 507 & -274.00 & 315.00 \\
\hline 103$\}$ & $>$ & 508 & -274.00 & 363.00 \\
\hline 104$\}$ & $>$ & 509 & -274.00 & 411.00 \\
\hline 105) & $>$ & 510 & -274.00 & 459.00 \\
\hline 106$\}$ & $>$ & 511 & -274.00 & 513.75 \\
\hline 107$\}$ & $>$ & 512 & -274.00 & 568.50 \\
\hline 108$\}$ & $>$ & 513 & -274.00 & 623.25 \\
\hline 109$\}$ & $>$ & 514 & -274.00 & 678.00 \\
\hline 110$\}$ & $>\$ \$$ & SLAB & S1 SOUTH GAI & LLERY \\
\hline 111) & $>$ & ' $S 1-1$ ' & 568.67 & 171.00 \\
\hline 1121 & $>$ & 's1-2' & 636.33 & 171.00 \\
\hline 113$\}$ & $>\$ \$$ & SLAB & S2 SOUTH GAI & LLERY \\
\hline 114) & $>$ & 'S2-1' & 568.67 & 315.00 \\
\hline 1151 & $>$ & ' $52-2$ ' & 636.33 & 315.00 \\
\hline 116$\}$ & $>\$ \$$ & SLAB & S3 SOUTH GAL & LLERY \\
\hline 117$)$ & $>$ & ' $53-1$ ' & 568.67 & 459.63 \\
\hline 118$)$ & $>$ & 's3-2' & 636.33 & 459.63 \\
\hline 119$\}$ & $>\$ \$$ & SLAB & S4 SOUTH GAI & LLERY \\
\hline 120$\}$ & $>$ & ' $54-1$ ' & 568.67 & 600.00 \\
\hline 121$\}$ & $>$ & $' s 4-2$ ' & 636.33 & 600.00 \\
\hline 122$\}$ & $>\$ \$$ & SLAB & S5 NORTH GAI & LLERY \\
\hline 123$\}$ & $>$ & 's5-1' & -91.33 & 171.00 \\
\hline 124$\}$ & $>$ & ' $55-2$ ' & -182.67 & 171.00 \\
\hline 225$\}$ & $>\$ \$$ & SLAB & S6 NORTH GAI & LLERY \\
\hline 126$\}$ & $>$ & 's6-1' & -91.33 & 315.00 \\
\hline 127$\}$ & $>$ & ' $56-2$ ' & -182.67 & 315.00 \\
\hline 128$\}$ & $>\$ \$$ & SLAB & S7 NORTH GAL & LLERY \\
\hline 129$\}$ & $>$ & ' $57-1$ ' & -91.33 & 459.00 \\
\hline 130$\}$ & $>$ & $\cdot 57-2^{\circ}$ & -182.67 & 459.00 \\
\hline 131$\}$ & $>\$ \$$ & SLAB & SB NORTH GAL & LLERY \\
\hline 132$\}$ & $>$ & $\cdot s 8-1 \cdot$ & $-91 \cdot 33$ & 678.00 \\
\hline 133$\}$ & $>$ & ' $58-2$ ' & -182.67 & 678.00 \\
\hline 134$\}$ & $>\$ \$$ & SLAB & S9 PIPE TUNN & NEL \\
\hline 1351 & $>$ & 's9-1' & 249.00 & 111.00 \\
\hline 136$\}$ & $>\$ \$$ & ROOF & TRUSS BOTTOM C & CHORD \\
\hline 137) & $>$ & $' T-1$ ' & 709.00 & 909.50 \\
\hline 138$\}$ & $>$ & ' $T-2$ ' & 634.00 & 909.50 \\
\hline 139) & $>$ & $\cdot T-3$ ' & 486.00 & 909.50 \\
\hline 140$\}$ & $>$ & ' $T-4$ ' & 338.00 & 909.50 \\
\hline 1411 & $>$ & $' T-5$ ' & 190.00 & 909.50 \\
\hline 142$\}$ & $>$ & ' $\mathrm{T}-6^{\prime}$ & 42.00 & 909.50 \\
\hline 1431 & $>$ & 'T-7' & -33.00 & 909.50 \\
\hline 144) & $>$ & $' T-8$ ' & 709.00 & 1003.50 \\
\hline 1451 & $>$ & $' T-9$ ' & 634.00 & 1003.50 \\
\hline 146$)$ & $>$ & ' $T-10^{\prime}$ & 560.00 & 1003.50 \\
\hline 1471 & $>$ & ' $\mathrm{T}-11$ ' & 486.00 & 1003.50 \\
\hline 148$\}$ & $>$ & ' $T-12$ ' & 412.00 & 1003.50 \\
\hline 1491 & $>$ & $' T-13$ ' & 338.00 & 1003.50 \\
\hline 150$\}$ & $>$ & ' $T-14$ ' & 264.00 & 1003.50 \\
\hline 151\} & $>$ & $\cdot T-15$ ' & 190.00 & 1003.50 \\
\hline
\end{tabular}

ATTTACHMENT-F: Calc. No. 0200W-CA-C0156 Rev. No. 0 Job No. 22192 
Attachment F: REDOX (Corrected Coordinate in "GT Strudl" Model) Output for Seismic Analysis (Using Ground Response Spectrum for "Existing PC3 Structures"- 10\% Damping)

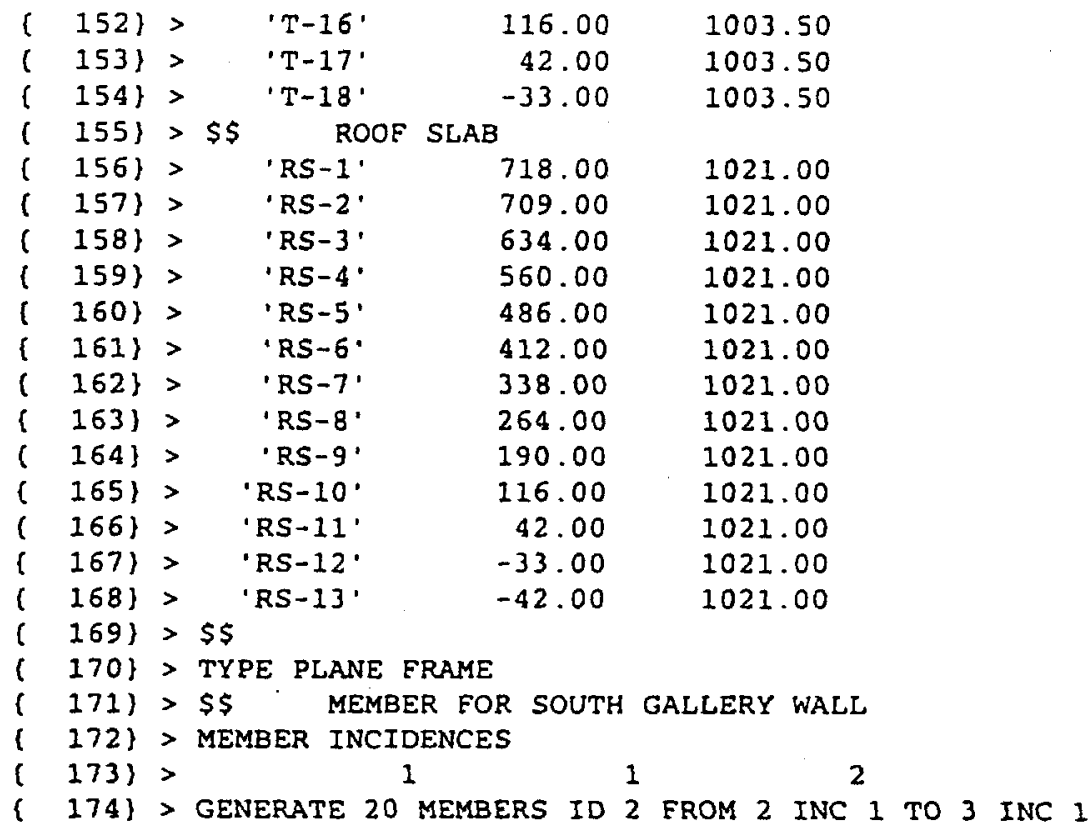

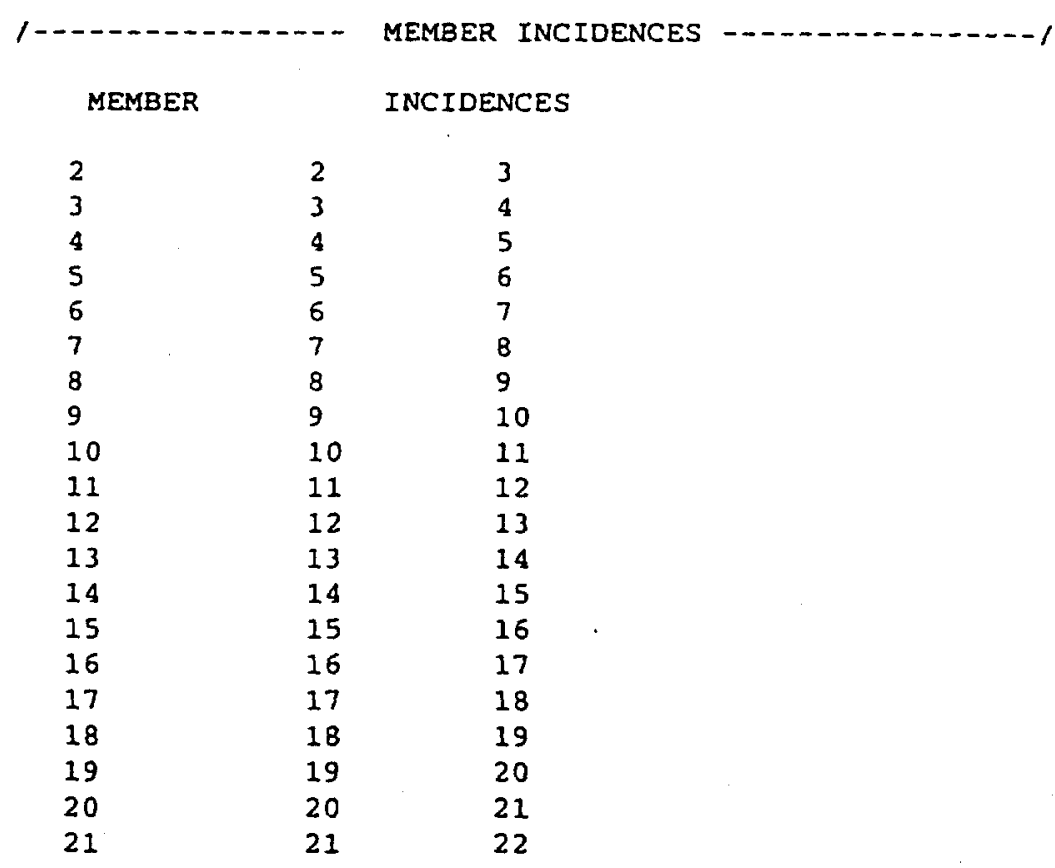

( 175) > \$\$ MEMBER FOR SOUTH CANYON WALL

( 176) > MEMBER INCIDENCES

( 177$)>\quad 101 \quad 101 \quad 102$

( 178 \} > GENERATE 14 MEMBERS ID 102 FROM 102 INC 1 TO 103 INC 1

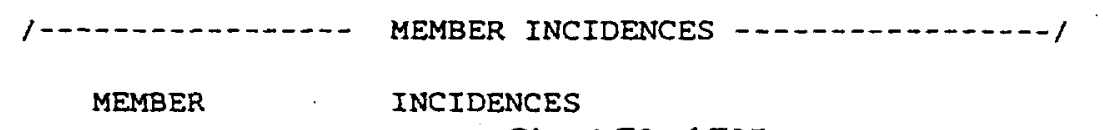

Sheet $\mathrm{F} 6$ of $\mathrm{F} 35$

ATITACHMENT-F: Calc. No. 0200W-CA-C0156 Rev. No. 0 Job No. 22192 
BHI-01299

Rev. 0

Attachment F: REDOX (Corrected Coordinate in "GT Strudl" Model) Output for Seismic Analysis (Using Ground Response Spectrum for "Existing PC3 Structures"- $10 \%$ Damping)

$\begin{array}{lll}102 & 102 & 103 \\ 103 & 103 & 104 \\ 104 & 104 & 105 \\ 105 & 105 & 106 \\ 106 & 106 & 107 \\ 107 & 107 & 108 \\ 108 & 108 & 109 \\ 109 & 109 & 110 \\ 110 & 110 & 111 \\ 111 & 111 & 112 \\ 112 & 112 & 113 \\ 113 & 113 & 114 \\ 114 & 114 & 115 \\ 115 & 115 & 116\end{array}$

( 179) > \$\$ MEMBER FOR SOUTH PIPE TUNNEL. WALL

( 180) > MEMBER INCIDENCES

$(181)>201 \quad 201 \quad 202$

( 182) > GENERATE 6 MEMBERS ID 202 FROM 202 INC 1 TO 203 INC 1

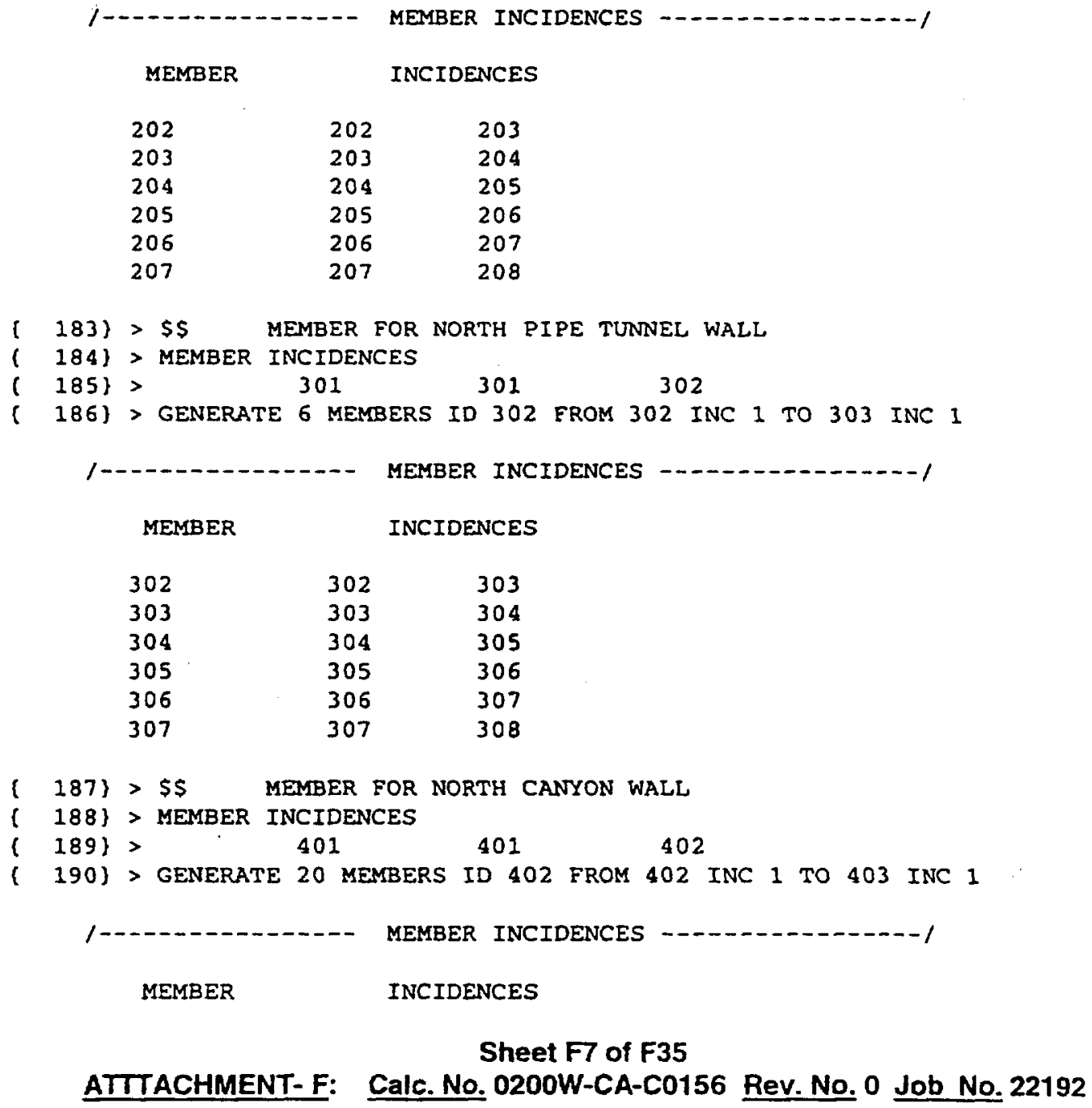

\begin{tabular}{lll} 
MEMBER & & \multicolumn{2}{c}{ MEMBER INCIDENCES } \\
302 & 302 & 303 \\
303 & 303 & 304 \\
304 & 304 & 305 \\
305 & 305 & 306 \\
306 & 306 & 307 \\
307 & 307 & 308
\end{tabular}

$\{187\}>\$ \$$ MEMBER FOR NORTH CANYON WALL

\{ 188\} > MEMBER INCIDENCES

(189)> 401 401 402

( 190 ) > GENERATE 20 MEMBERS ID 402 FROM 402 INC 1 TO 403 INC 1

Sheet F7 of F35

ATTTACHMENT-F: Calc. No. $0200 W-C A-C 0156$ Rev. No. 0 Job No. 22192 
BHI-01299

Rev. 0

Attachment F: REDOX (Corrected Coordinate in "GT Strud!" Model) Output for Seismic Analysis (Using Ground Response Spectrum for "Existing PC3 Structures"- 10\% Damping)

$\begin{array}{lll}402 & 402 & 403 \\ 403 & 403 & 404 \\ 404 & 404 & 405 \\ 405 & 405 & 406 \\ 406 & 406 & 407 \\ 407 & 407 & 408 \\ 408 & 408 & 409 \\ 409 & 409 & 410 \\ 410 & 410 & 411 \\ 411 & 411 & 412 \\ 412 & 412 & 413 \\ 413 & 413 & 414 \\ 414 & 414 & 415 \\ 415 & 415 & 416 \\ 416 & 416 & 417 \\ 417 & 417 & 418 \\ 418 & 418 & 419 \\ 419 & 419 & 420 \\ 420 & 420 & 421 \\ 421 & 421 & 422\end{array}$

( 191\} > \$\$ MEMBER FOR NORTH GALLERY WALL

( 192) > MEMBER INCIDENCES

[ 193$\}>502 \quad 502 \quad 503$

( 194) > GENERATE 11 MEMBERS ID 503 FROM 503 INC 1 TO 504 INC 1

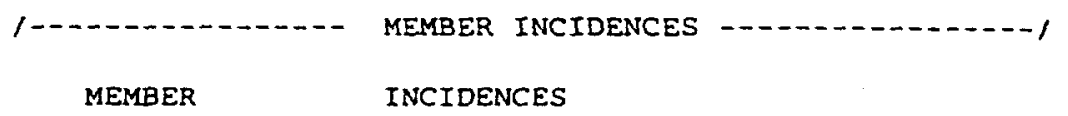

$\begin{array}{lll}503 & 503 & 504 \\ 504 & 504 & 505 \\ 505 & 505 & 506 \\ 506 & 506 & 507 \\ 507 & 507 & 508 \\ 508 & 508 & 509 \\ 509 & 509 & 510 \\ 510 & 510 & 511 \\ 511 & 511 & 512 \\ 512 & 512 & 513 \\ 513 & 513 & 514\end{array}$

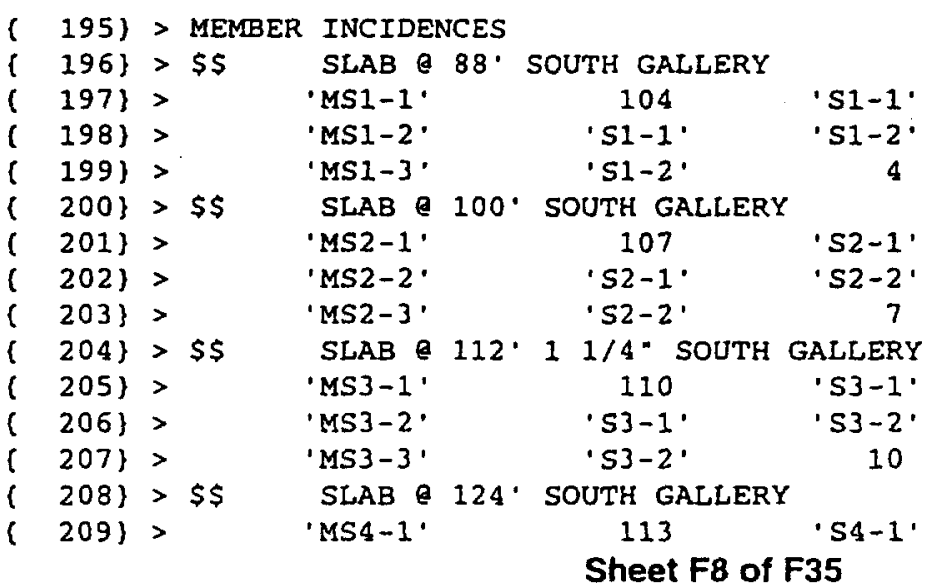

ATTTACHMENT-F: Calc. No. 0200W-CA-C0156 Rev. No. 0 Job No. 22192 
BHI-01299

Rev. 0

Attachment F: REDOX (Corrected Coordinate in "GT Strudl" Model) Output for Seismic Analysis (Using Ground Response Spectrum for "Existing PC3 Structures"- 10\% Damping)

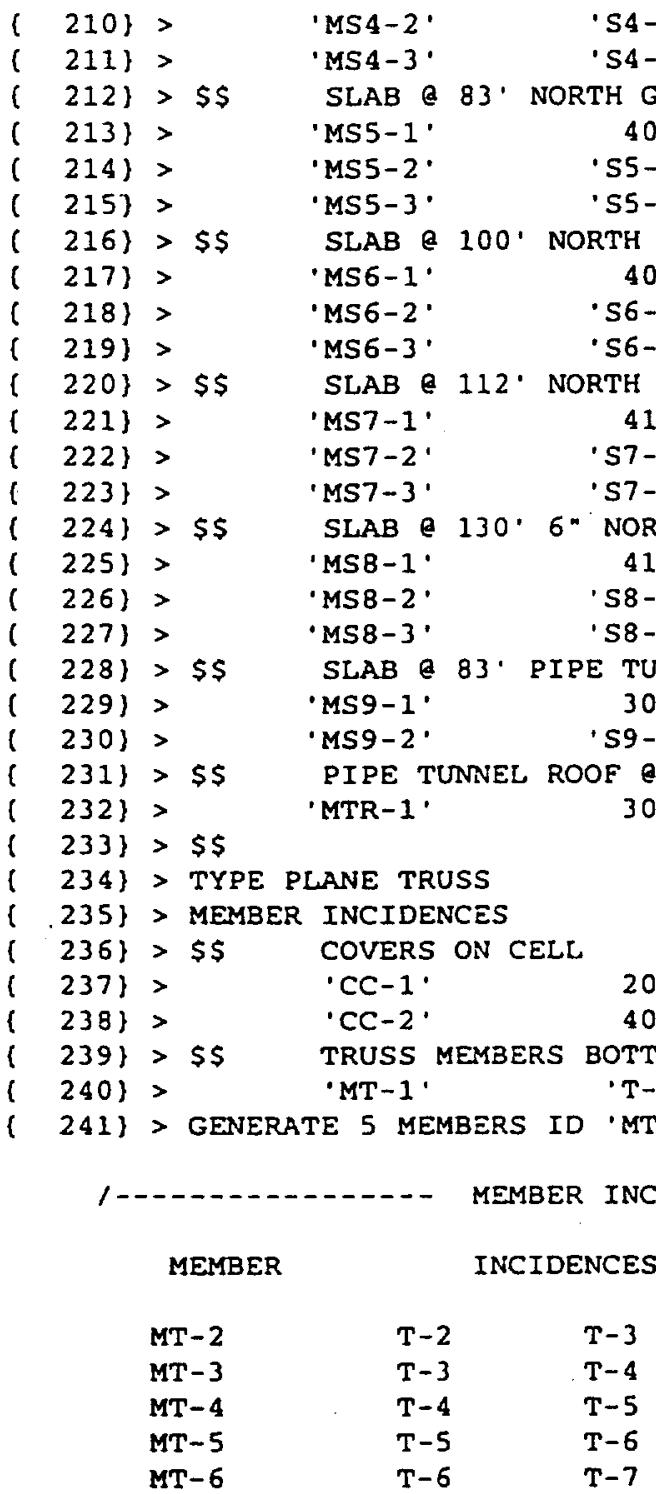

( 242\} > \$\$ TRUSS MEMBERS TOP CHORD

( 243) > MEMBER INCIDENCES

( 244) > 'MT-7' 'T-8' 'T-9'

( 245) > GENERATE 9 MEMBERS ID 'MT-8' INC 1 FROM 'T-9' INC 1 TO 'T-10' INC 1

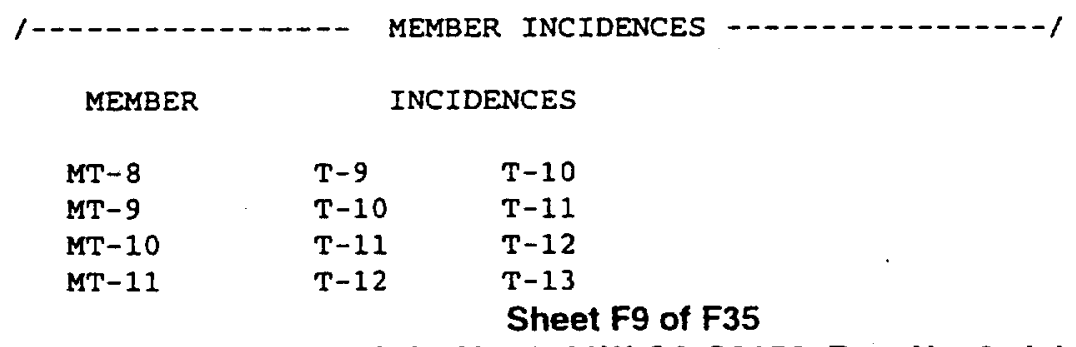

ATTTACHMENT-F: Calc. No. 0200W-CA-C0156 Rev. No. 0 Job No. 22192 
BHI-01299

Rev. 0

Attachment F: REDOX (Corrected Coordinate in "GT Strudl" Model) Output for Seismic Analysis (Using Ground Response Spectrum for "Existing PC3 Structures"- 10\% Damping)

$\begin{array}{lll}M T-12 & T-13 & T-14 \\ M T-13 & T-14 & T-15 \\ M T-14 & T-15 & T-16 \\ M T-15 & T-16 & T-17 \\ M T-16 & T-17 & T-18\end{array}$

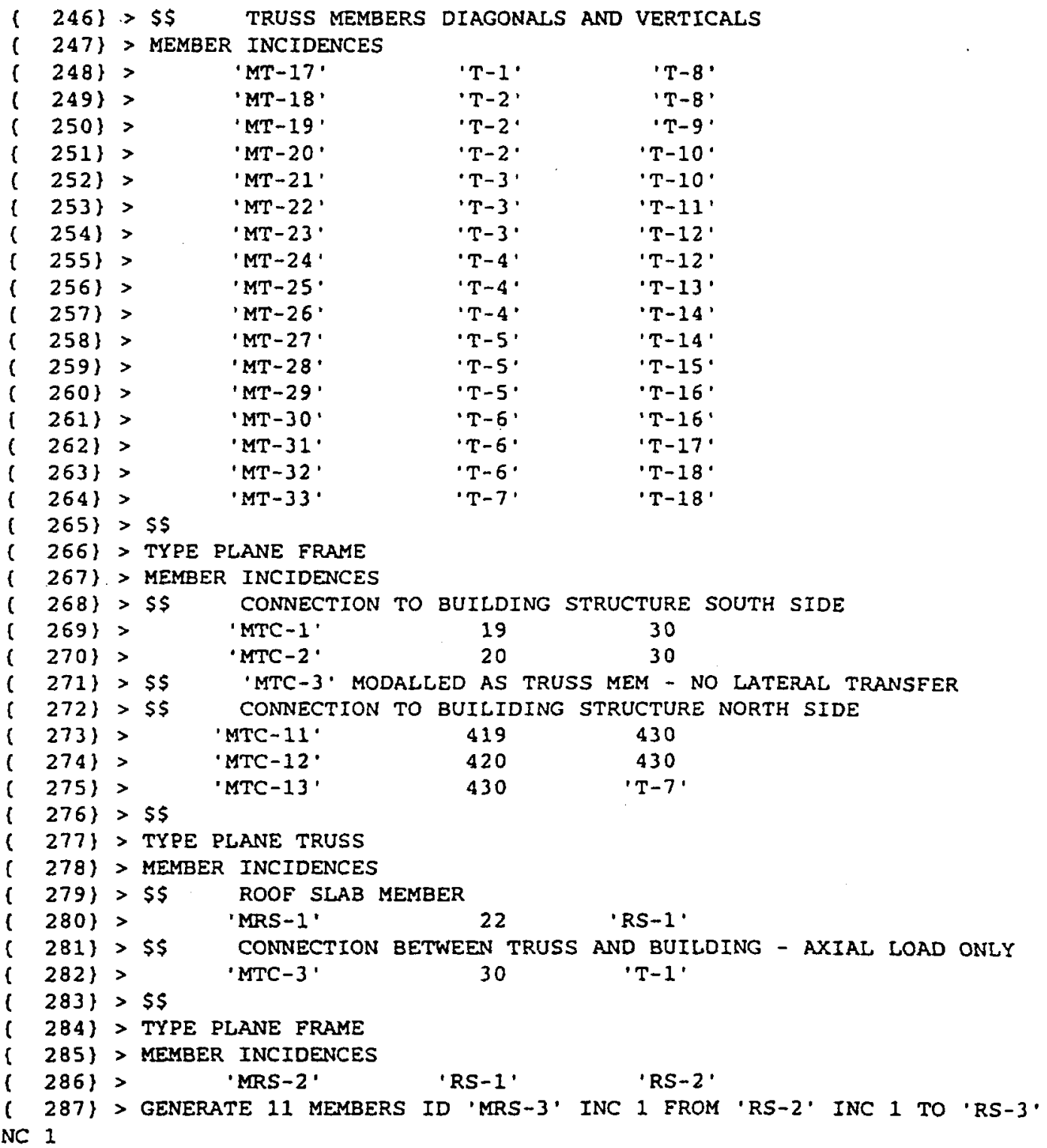

$\begin{array}{lll}\text { MEMBER } & \text { MEMBER INCIDENCES } \\ \text { MRS-3 } & \text { RS-2 } & \text { RS-3 } \\ \text { MRS-4 } & \text { RS-3 } & \text { RS-4 } \\ \text { MRS-5 } & \text { RS-4 } & \text { RS-5 } \\ & & \text { Sheet F10 of F35 }\end{array}$

ATTTACHMENT-F: Calc. No. $0200 W-C A-C 0156$ Rev. No. 0 Job No. 22192 
BHI-01299

Rev. 0

Attachment F: REDOX (Corrected Coordinate in "GT Strudl" Model) Output for Seismic Analysis ........ (Using Ground Response Spectrum for "Existing PC3 Structures" - 10\% Damping)

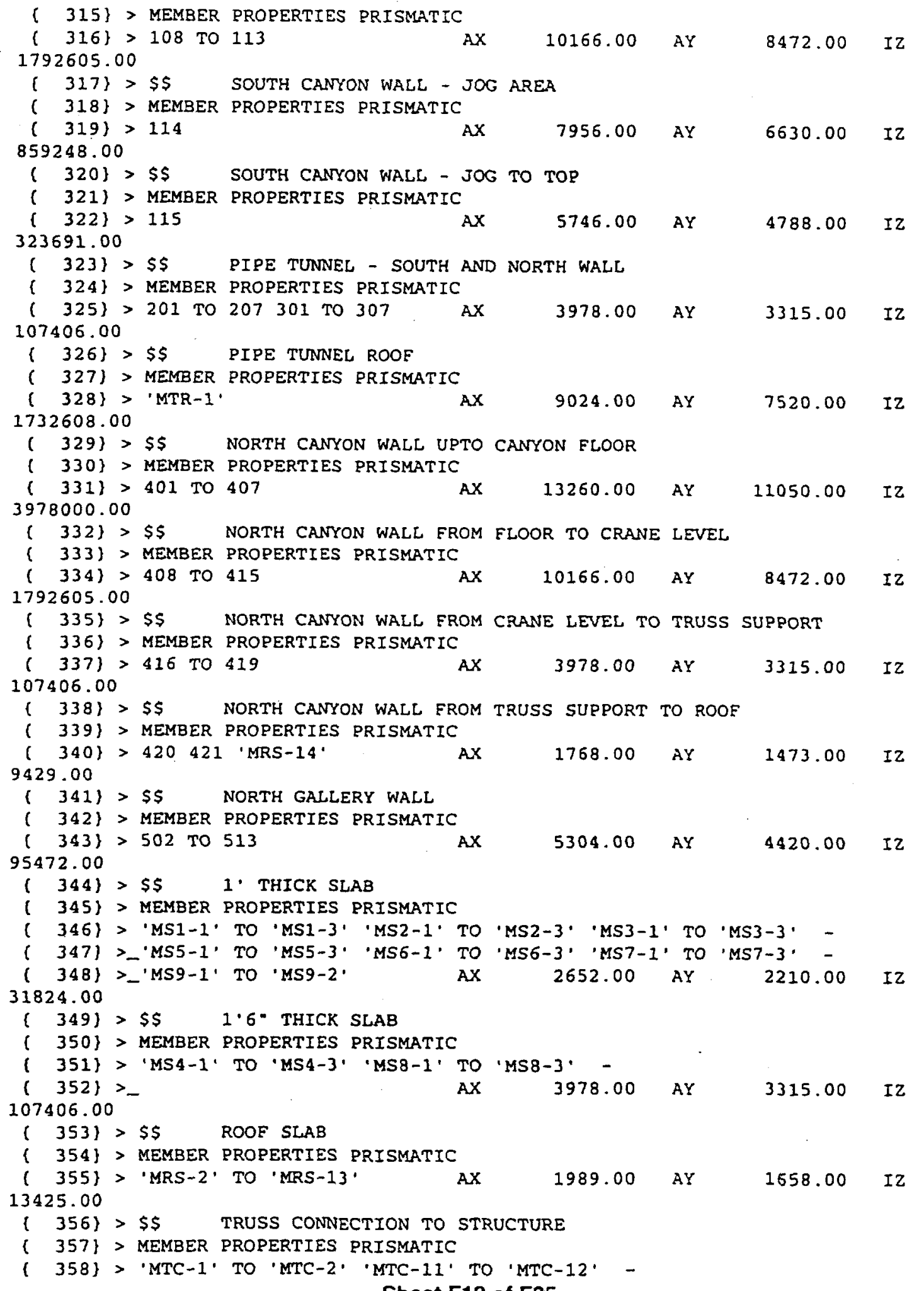

ATITACHMENT-F: Calc. No. 0200W-CA-C0156 Rev. No. 0 Job No. 22192 
BHI-01299

Rev. 0

Attachment F: REDOX (Corrected Coordinate in "GT Strudl" Model) Output for Seismic Analysis (Using Ground Response Spectrum for "Existing PC3 Structures"- 10\% Damping)

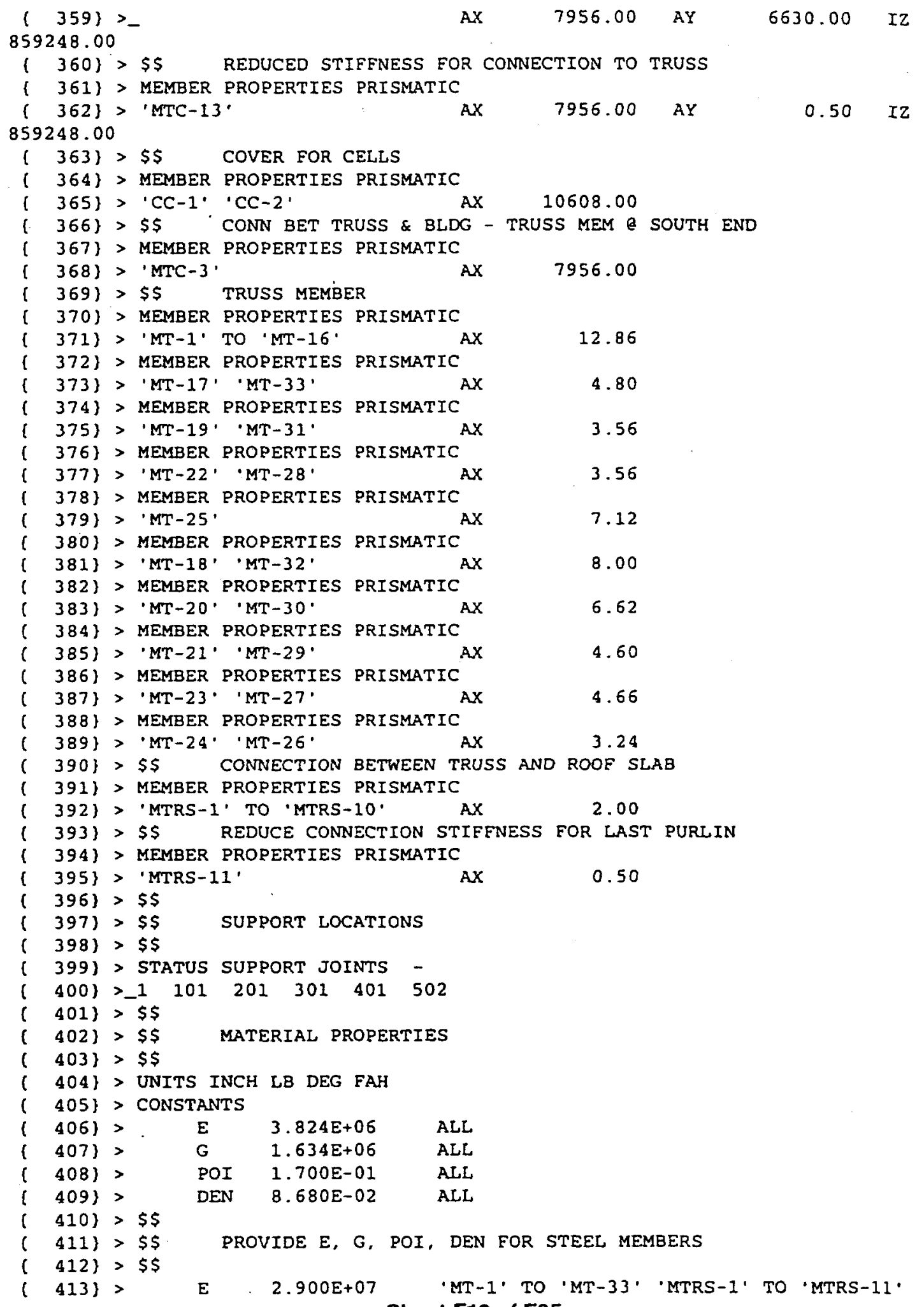

ATTTACHMENT-F: Calc. No. 0200W-CA-C0156 Rev. No. 0 Job No. 22192 
BHI-01299

Rev. 0

Attachment F: REDOX (Corrected Coordinate in "GT Strudl" Model) Output for Seismic Analysis (Using Ground Response Spectrum for "Existing PC3 Structures"- 10\% Damping)

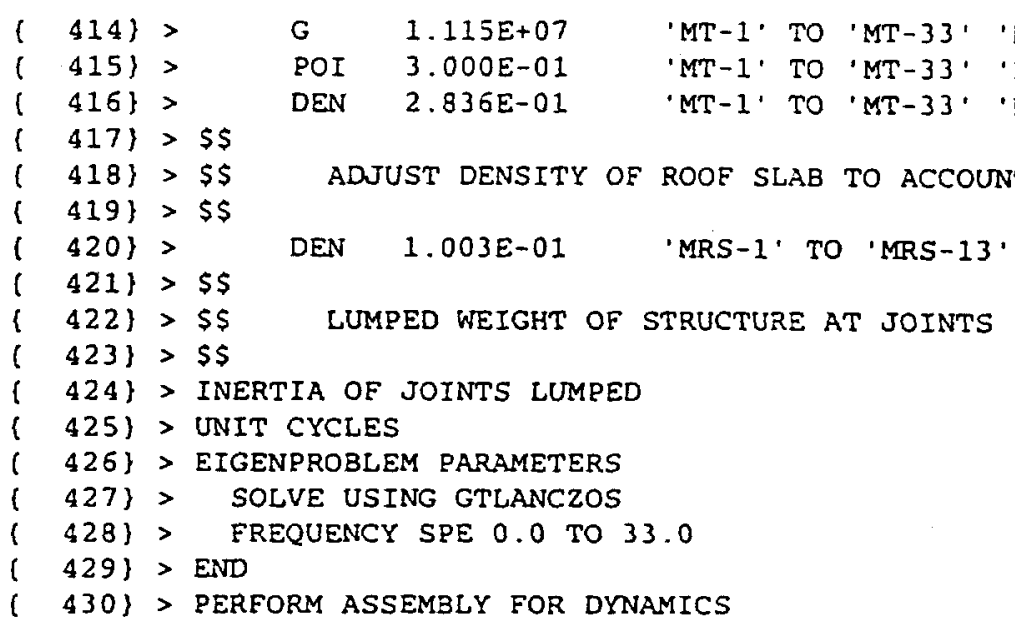

BANDWIDTH INFORMATION BEFORE RENUMBERING.

THE MAXIMUM BANDWIDTH IS 100 AND OCCURS AT JOINT RS-1 THE AVERAGE BANDWIDTH IS 11.165 THE STANDARD DEVIATION OF THE BANDWIDTH IS 21.338

32.503

BANDWIDTH INFORMATION AETER RENUMBERING.

THE MAXIMUM BANDWIDTH IS THE AVERAGE BANDWIDTH IS THE STANDARD DEVTATION OF T
9 AND OCCURS AT JOINT S7-2

5.511

$\begin{array}{ll} & =1 \\ \text { TIME FOR CONSISTENCY CHECK FOR } 176 \text { MEMBERS } & 0.00 \text { SECONDS } \\ \text { TIME FOR BANDWIDTH REDUCTION } & 0.01 \text { SECONDS } \\ \text { TIME TO GENERATE IT6 ELEMENT STIF. MATRICES } & 0.02 \text { SECONDS } \\ \text { TIME TO ASSEMBLE THE STIFFNESS MATRIX } & 0.01 \text { SECONDS } \\ \text { TIME TO PROCESS I39 JOINTS } & 0.00 \text { SECONDS } \\ \text { TIME TO GENERATE REDUCED STIFFNESS MATRIX } & 0.02 \text { SECONDS } \\ \text { TIME TO ASSEMBLE LUMPED MASS MATRIX } & 0.00 \text { SECONDS }\end{array}$
( 431$\}>$ PERFORM EIGENVALUE ANALYSIS

** STRUdL MESSAGE DY.409 - THERE ARE 22 FREQUENCIES LESS THAN OR EQUAL TO THE SPECIFIED MAXIMUM FREQUENCY

TIME TO SOLVE EIGENPROBLEM

TIME TO TRANSFORM EIGENVECTORS TO JOINTS

$$
\begin{array}{ll}
0.35 & \text { SECONDS } \\
0.04 & \text { SECONDS }
\end{array}
$$

\section{Sheet F14 of F35}

ATTTACHMENT-F: Calc. No. 0200W-CA-C0156 Rev. No. 0 Job No. 22192 
BHI-01299

Rev. 0

Attachment F: REDOX (Corrected Coordinate in "GT Strudl" Model) Output for Seismic Analysis (Using Ground Response Spectrum for "Existing PC3 Structures"- 10\% Damping)

*** * STRUDL MESSAGE - STURM SEQUENCE CHECK WAS SUCCESSFUL - THERE ARE No MISSING MODES

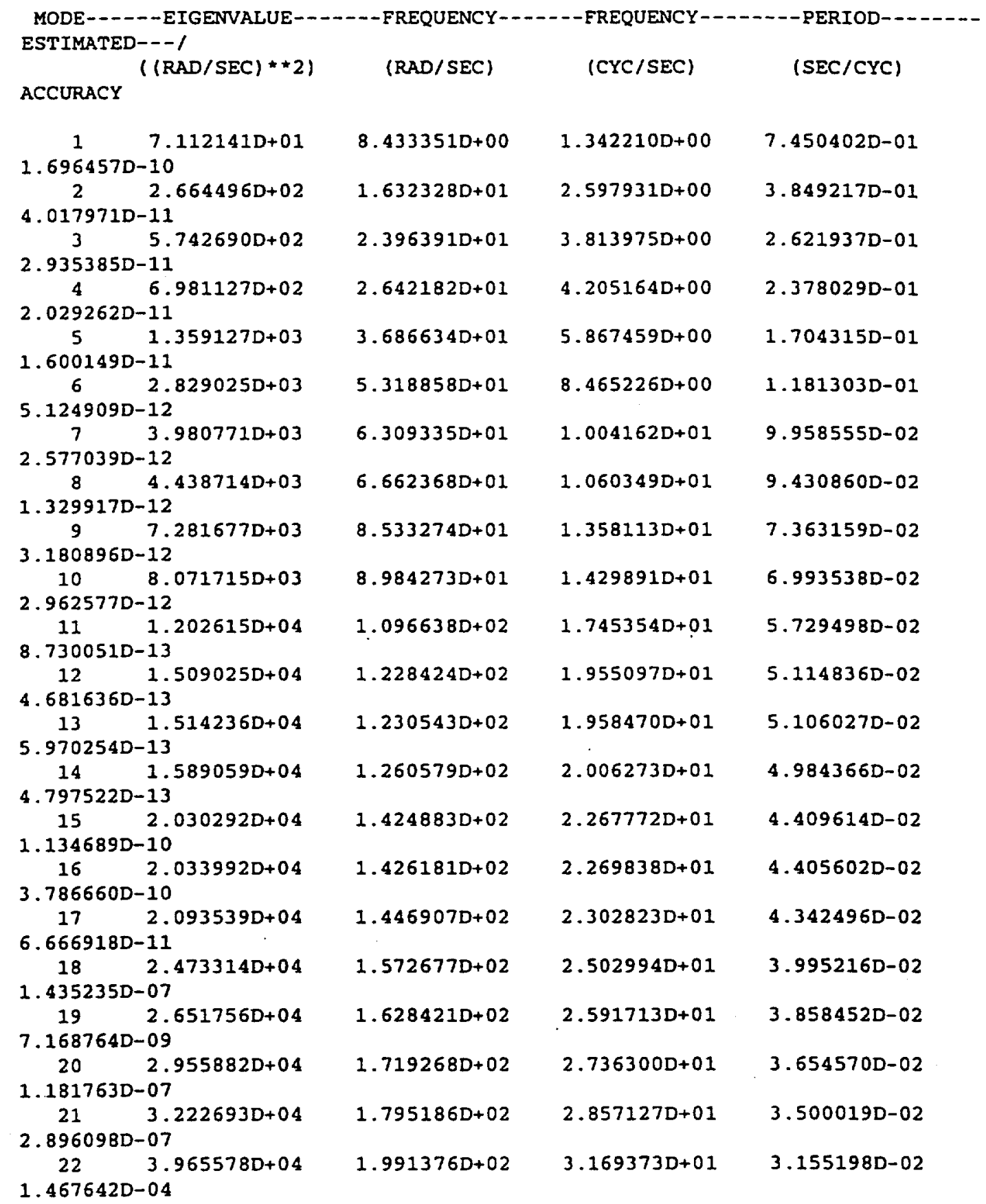


BHI-01299

Rev. 0

Attachment F: REDOX (Corrected Coordinate in "GT Strudl" Model) Output for Seismic Analysis (Using Ground Response Spectrum for "Existing PC3 Structures"- 10\% Damping)

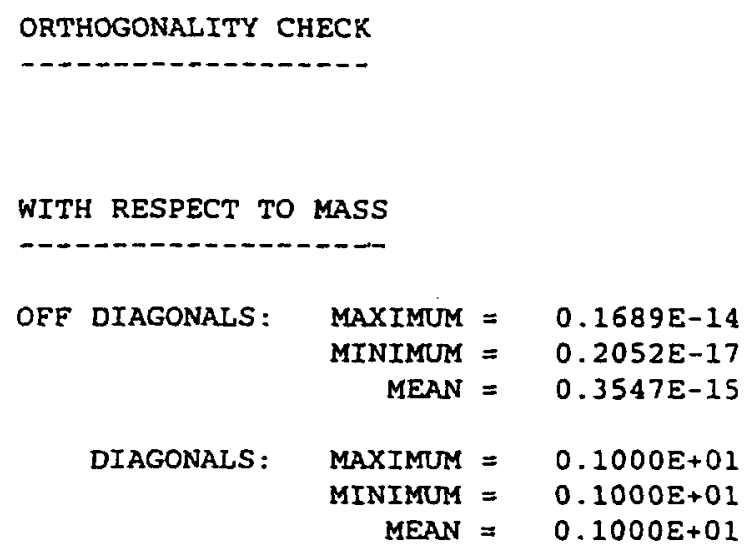


BHI-01299

Rev. 0

Attachment F: REDOX (Corrected Coordinate in "GT Strudl" Model) Output for Seismic Analysis (Using Ground Response Spectrum for "Existing PC3 Structures"- 10\% Damping)

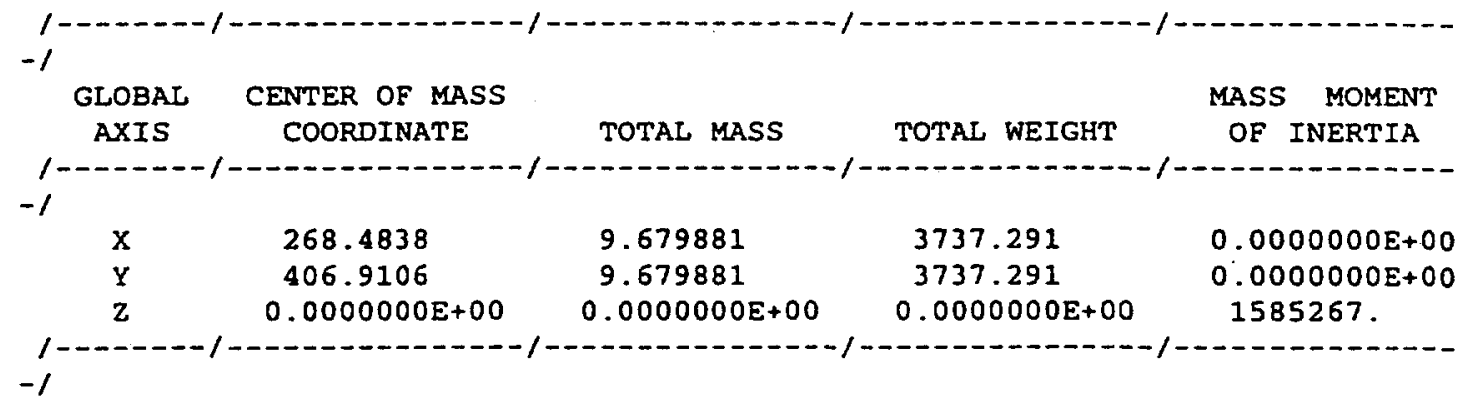

( 435) > LIST DYNAMIC PARTICPATION FACTORS

1

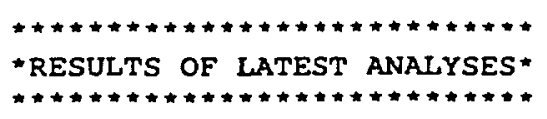

PROBLEM - REDOX BU TITLE - 2-D ANALYSIS OF TYPICAL SLICE

ACTIVE UNITS INCH KIP CYC DEGF SEC

NORMALIZED PARTICIPATYON FACTORS

* OF X DIRECTION MASS PARTICIPATING
MODE
PERCENT
MODE

TOTAL PERCENTAGE OF X DIRECTION MASS PARTICIPATING: 89.359

\& OF Y DIRECTION MASS PARTICIPATING

\section{Sheet F17 of F35}

ATITACHMENT-F: Calc. No. 0200 W-CA-C0156 Rev. No. 0 Job No. 22192 
Attachment F: REDOX (Corrected Coordinate in "GT Strudl" Model) Outout for Seismic Analysis (Using Ground Response Spectrum for "Existing PC3 Structures"- 10\% Damping)

\begin{tabular}{|c|c|c|c|c|c|c|c|}
\hline $\begin{array}{l}\text { MODE } \\
\text { PERCENT }\end{array}$ & $\begin{array}{l}\text { PERCENT } \\
\text { MODE }\end{array}$ & $\begin{array}{c}\text { MODE } \\
\text { PERCENT }\end{array}$ & $\begin{array}{l}\text { PERCENT } \\
\text { MODE }\end{array}$ & \multicolumn{4}{|c|}{ PERCENT } \\
\hline 1 & $0.4996426 \mathrm{E}-03$ & 2 & $0.2375953 \mathrm{E}-01$ & 3 & 0.9383560 & 4 & 2.563886 \\
\hline 0.2 & $2472395 E-04$ & 0.7 & $738022 E-02$ & & & & \\
\hline 7 & $0.8796270 \mathrm{E}-03$ & 8 & $0.2613380 \mathrm{E}-03$ & 9 & $0.4690954 E-02$ & 10 & \\
\hline 0.22587 & $782 \mathrm{E}-02 \quad 11$ & 1.0075 & $29 \quad 12$ & 0.69897 & $779 E-02$ & & \\
\hline 13 & 0.2568285 & 14 & 2.968185 & 15 & 4.597464 & 16 & \\
\hline 0.40551 & $185 E-01$ & 0.46916 & 18 & 4.9870 & 41 & & \\
\hline 19 & 0.1043740 & 20 & 0.7674618 & 21 & 0.8030276 & 22 & 1.941545 \\
\hline
\end{tabular}

TOTAL PERCENTAGE OF Y DIRECTION MASS PARTICIPATING: 21.493

NO MASS IN Z DIRECTION

$(436)>\$ \$$

(437\}> UNITS FEET SECONDS

(438) > DELETE RESPONSE SPECTRA ' PC3.

** * STRUDL ERROR DY.81 - FILE PC3 DOES NOT EXIST ON USER DATA SET

( 439 ) > STORE RESPONSE SPECTRA ACCELERATION LOG VS FREQUENCY LOG 'PC3.'

(440) > DAMPING 0.10 FACTOR 32.2

( 441\}) $>\$$ SPECTRA. IN g's

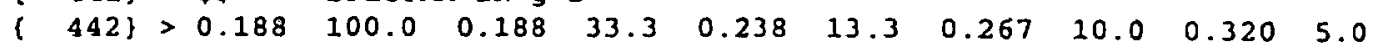
0.3023 .3

$\begin{array}{llllllllll}(443)>0.233 & 2.0 & 0.146 & 1.0 & 0.078 & 0.5 & 0.029 & 0.25\end{array}$

(444) > RESPONSE SPECTRA LOAD 1

(445) > SUPPORT ACCELERATION

$(446)>$. TRANSLATIONAL X 1.00 FILE 'PC3.

( 447) > END RESPONSE SPECTRA LOADING

(448) > DAMPING RATIO 0.1030

( 449 ) > PERFORM RESPONSE SPECTRA ANALYSIS

TIME TO COMPUTE RESPONSE SPECTRA RESULTS 0.00 SECONDS

( 450$\}>$ COMPUTE RESPONSE SPECTRA DISPLACEMENT ACC FORCES REACTIONS (451\} > MODAL COMBINATION NRC TPM

TIME FOR RESPONSE SPECTRA COMPUTATION 0.49 SECONDS

$\{452\}>\$ \$$

$\{453\}>$ CREATE PSEUDO STATIC LOAD 'NS' FROM NRC TPM LOAD 1

\{ 454\} > LIST RESPONSE SPECTRUM SPECTRAL ACCELERATION

1

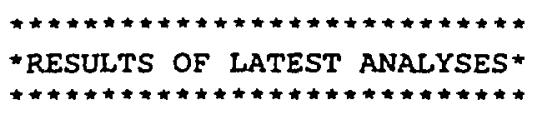

PROBLEM - REDOX BU TITLE - 2-D ANALYSIS OF TYPICAL SLICE

ACTIVE UNITS FEET KIP CYC DEGF SEC

ATTTACHMENT-F: Calc. No. 0200W-CA-C0156 Rev. No. 0 Job No. 22192 
This page cannot be converted.

Please view the native document

for the original page. 
BHI-01299

Rev. 0

Attachment F: REDOX (Corrected Coordinate in "GT Strudl" Model) Output for Seismic Analysis (Using Ground Response Spectrum for "Existing PC3 Structures"- 10\% Damping)

\begin{tabular}{|c|c|c|c|c|c|}
\hline $\begin{array}{c}1 \\
970.3920\end{array}$ & 1 & NRC & TPM & 201.1614 & 36.15702 \\
\hline $\begin{array}{c}1 \\
804.3917\end{array}$ & 2 & NRC & TPM & 201.1614 & 36.15702 \\
\hline $\begin{array}{l}2 \\
804.3917\end{array}$ & 2 & NRC & TPM & 201.1494 & 35.96434 \\
\hline $\begin{array}{l}2 \\
642.1326\end{array}$ & 3 & NRC & TPM & 201.1494 & 35.96434 \\
\hline $\begin{array}{l}3 \\
642.1326\end{array}$ & 3 & NRC & TPM & 201.1254 & 35.28999 \\
\hline$\stackrel{3}{488.1228}$ & 4 & NRC & TPM & 201.1254 & 35.28999 \\
\hline $\begin{array}{c}4 \\
618.5902\end{array}$ & 4 & NRC & TPM & 186.8275 & 35.83604 \\
\hline $\begin{array}{c}4 \\
513.4439\end{array}$ & 5 & NRC & TPM & 186.8275 & 35.83604 \\
\hline $\begin{array}{c}5 \\
513.4439\end{array}$ & 5 & NRC & TPM & 186.7884 & 34.18269 \\
\hline$\stackrel{5}{434.6510}$ & 6 & NRC & TPM & 186.7884 & 34.18269 \\
\hline $\begin{array}{l}6 \\
434.6510\end{array}$ & 6 & NRC & TPM & 186.7410 & 32.12725 \\
\hline $\begin{array}{l}6 . \\
393.0638\end{array}$ & 7 & NRC & TPM & 186.7410 & 32.12725 \\
\hline $\begin{array}{c}7 \\
559.1739\end{array}$ & 7 & NRC & TPM & 164.7368 & 37.87165 \\
\hline $\begin{array}{l}7 \\
441.8791\end{array}$ & 8 & NRC & TPM & 164.7368 & 37.87165 \\
\hline $\begin{array}{l}B \\
441.8791\end{array}$ & 8 & NRC & TPM & 164.6717 & 34.09465 \\
\hline$\stackrel{8}{357.2165}$ & 9 & NRC & TPM & 164.6717 & 34.09465 \\
\hline$\stackrel{9}{357.2165}$ & 9 & NRC & TPM & 164.5989 & 29.73448 \\
\hline $\begin{array}{l}9 \\
314.7783\end{array}$ & 10 & NRC & TPM & 164.5989 & 29.73448 \\
\hline 10 & 10 & NRC & TPM & 130.7412 & 47.03323 \\
\hline
\end{tabular}

508.0317

ATITACHMENT-F: Calc. No. 0200W-CA-C0156 Rev. No. 0 Job No. 22192 
BHI-01299

Rev. 0

Attachment F: REDOX (Corrected Coordinate in "GT Strudl" Model) Output for Seismic Analysis

...... (Using Ground Response Spectrum for "Existing PC3 Structures"- 10\% Damping)

\begin{tabular}{|c|c|c|c|c|c|}
\hline $\begin{array}{l}10 \\
550.9773\end{array}$ & 11 & NRC & TPM & 130.7412 & 47.03323 \\
\hline $\begin{array}{l}11 \\
550.9772\end{array}$ & 11 & NRC & TPM & 130.6540 & 44.03407 \\
\hline $\begin{array}{l}11 \\
643.7210\end{array}$ & 12 & NRC & TPM & 130.6540 & 44.03407 \\
\hline $\begin{array}{l}12 \\
643.7210\end{array}$ & 12 & NRC & TPM & 130.5649 & 41.65655 \\
\hline $\begin{array}{r}12 \\
775.7785\end{array}$ & 13 & NRC & TPM & 130.5649 & 41.65655 \\
\hline $\begin{array}{l}13 \\
1670.649\end{array}$ & 13 & NRC & TPM & 25.18997 & 87.30887 \\
\hline $\begin{array}{l}13 \\
1306.260\end{array}$ & 14 & NRC & TPM & 25.18997 & 87.30887 \\
\hline $\begin{array}{l}14 \\
1306.260\end{array}$ & 14 & NRC & TPM & 25.09494 & 77.39918 \\
\hline $\begin{array}{l}14 . \\
982.6647\end{array}$ & 15 & NRC & TPM & 25.09494 & 77.39918 \\
\hline $\begin{array}{l}15 \\
982.6647\end{array}$ & 15 & NRC & TPM & 36.92836 & 63.43979 \\
\hline $\begin{array}{l}15 \\
879.8358\end{array}$ & 16 & NRC & TPM & 36.92836 & 63.43979 \\
\hline $\begin{array}{l}16 \\
879.8358\end{array}$ & 16 & NRC & TPM & 24.91553 & 63.46779 \\
\hline $\begin{array}{l}16 \\
582.1096\end{array}$ & 17 & NRC & TPM & 24.91553 & 63.46779 \\
\hline $\begin{array}{l}17 \\
582.1096\end{array}$ & 17 & NRC & TPM & 24.78508 & 54.88236 \\
\hline $\begin{array}{l}17 \\
325.1920\end{array}$ & 18 & NRC & TPM & 24.78508 & 54.88236 \\
\hline $\begin{array}{l}18 \\
325.1920\end{array}$ & 18 & NRC & TPM & 24.65595 & 43.43308 \\
\hline $\begin{array}{l}18 \\
125.9827\end{array}$ & 19 & NRC & TPM & 24.65595 & 43.43308 \\
\hline $\begin{array}{l}19 \\
22.69379\end{array}$ & 19 & NRC & TPM & 12.88404 & 4.342622 \\
\hline 19 & 20 & NRC & TPM & 12.88404 & 4.342622 \\
\hline
\end{tabular}

ATITACHMENT-F: Calc. No. 0200 W-CA-C0156 Rev. No. 0 Job No. 22192 
BHI-01299

Rev. 0

Attachment F: REDOX (Corrected Coordinate in "GT Strudl" Model) Output for Seismic Analysis (Using Ground Response Spectrum for "Existing PC3 Structures"- 10\% Damping)

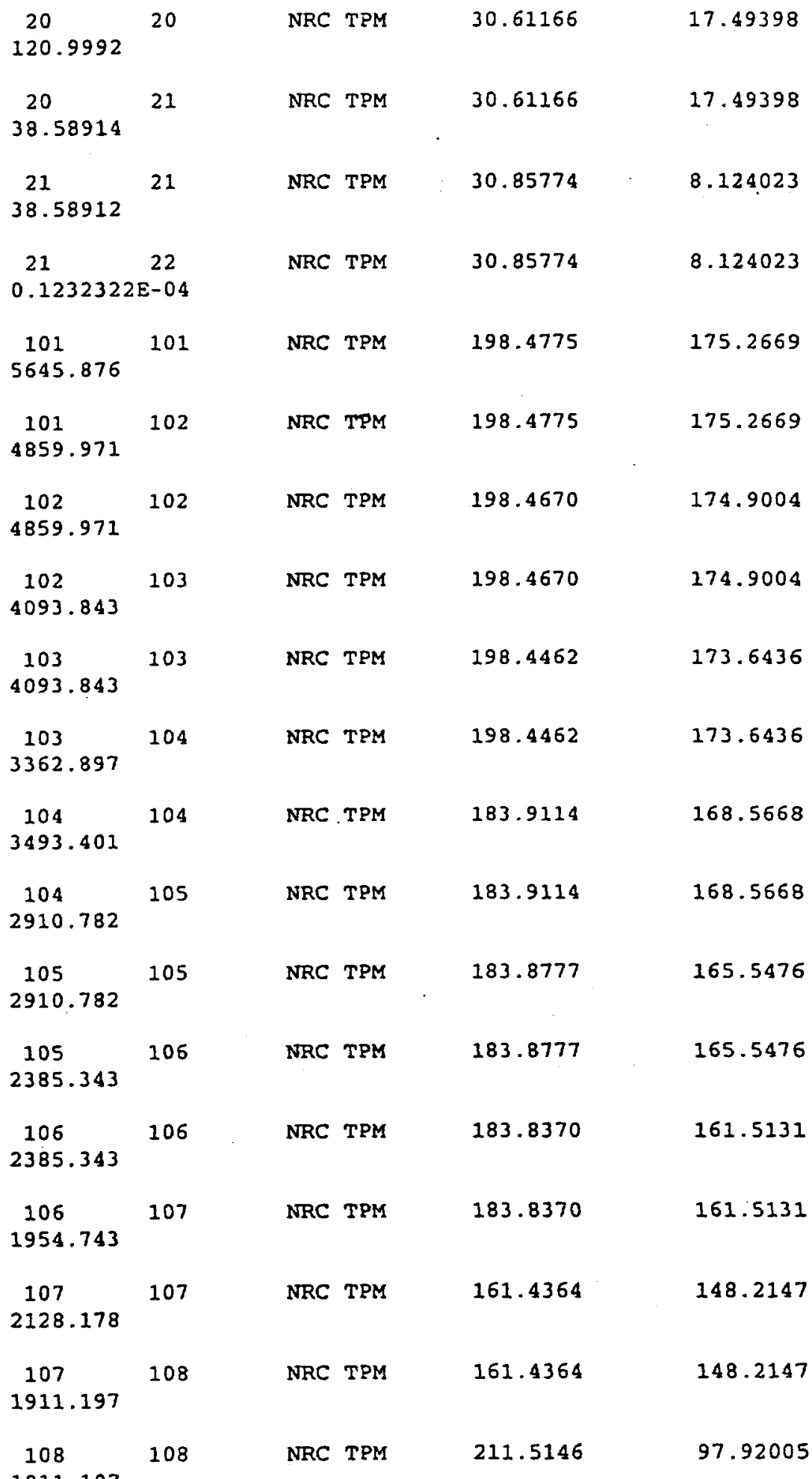

1911.197 Sheet F22 of F35

ATTTACHMENT-F: Calc. No. 0200W-CA-C0156 Rev. No. 0 Job No. 22192 
BHI-01299

Rev. 0

Attachment F: FEDOX (Corrected Coordinate in "GT Strudl" Model) Output for Seismic Analysis -.... (Using Ground Response Spectrum for "Existing PC3 Structures"- 10\% Damping)

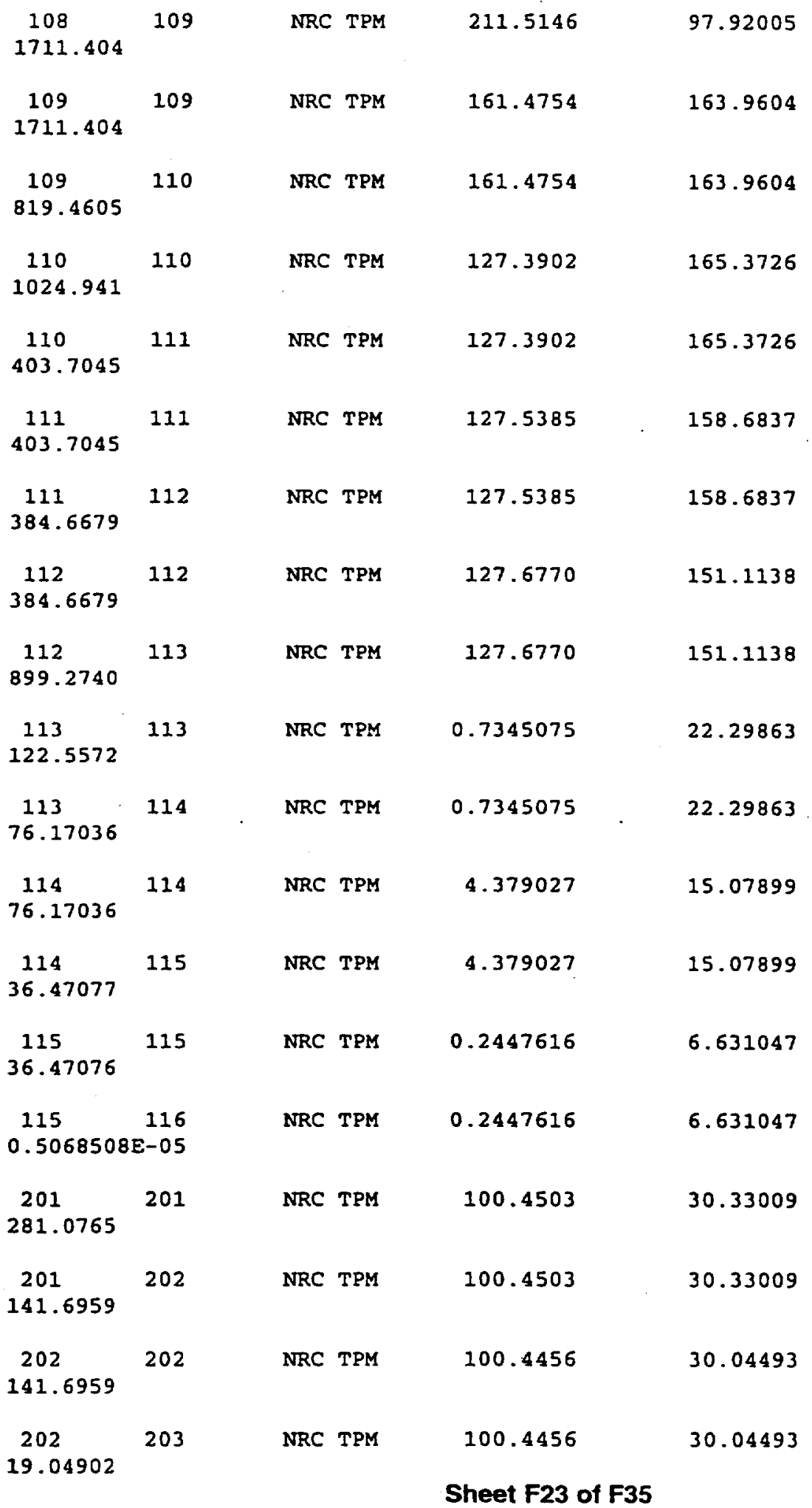

ATTTACHMENT-F: Calc. No. $0200 W-C A-C 0156$ Rev. No. 0 Job No. 22192 
Attachment F: REDOX (Corrected Coordinate in "GT Strudl" Model) Qutput for Seismic Analysis (Using Ground Response Spectrum for "Existing PC3 Structures"- $10 \%$ Damping)

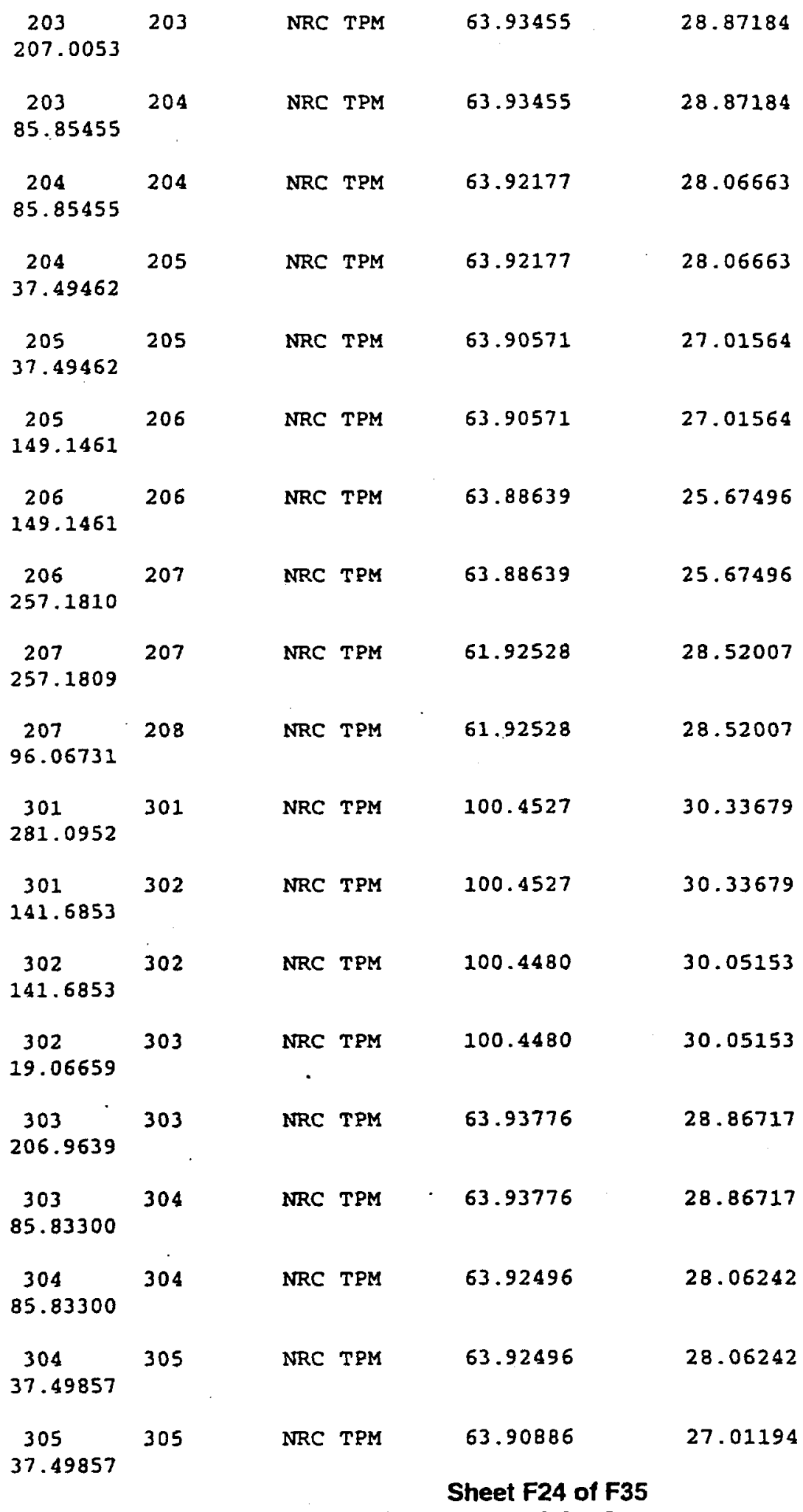

ATTTACHMENT-F: Calc. No. 0200W-CA-C0156 Rev. No. 0 Job No. 22192 
BHI-01299

Rev. 0

Attachment F: REDOX (Corrected Coordinate in "GT Strudl" Model) Output for Seismic Analysis (Using Ground Response Spectrum for "Existing PC3 Structures"- 10\% Damping)

\begin{tabular}{|c|c|c|c|c|c|}
\hline $\begin{array}{l}305 \\
149.1347\end{array}$ & 306 & NRC & TPM & 63.90886 & 27.01194 \\
\hline $\begin{array}{c}306 \\
149.1347\end{array}$ & 306 & NRC & TPM & 63.88952 & 25.67195 \\
\hline $\begin{array}{l}306 \\
257.1565\end{array}$ & 307 & NRC & TPM & 63.88952 & 25.67195 \\
\hline $\begin{array}{l}307 \\
257.1565\end{array}$ & 307 & NRC & TPM & 61.92609 & 28.52394 \\
\hline $\begin{array}{l}307 \\
96.02198\end{array}$ & 308 & NRC & TPM & 61.92609 & 28.52394 \\
\hline $\begin{array}{r}401 \\
4386.459\end{array}$ & 401 & NRC & TPM & 94.41989 & 160.7467 \\
\hline $\begin{array}{c}401 \\
3724.866\end{array}$ & 402 & NRC & TPM & 94.41989 & 160.7467 \\
\hline $\begin{array}{r}402 \\
3724.866\end{array}$ & 402 & NRC & TPM & 94.40491 & 160.3226 \\
\hline $\begin{array}{r}402 . \\
3111.542\end{array}$ & 403 & NRC & TPM & 94.40491 & 160.3226 \\
\hline $\begin{array}{l}403 \\
3111.542\end{array}$ & 403 & NRC & TPM & 94.37518 & 158.9189 \\
\hline $\begin{array}{r}403 \\
2582.042\end{array}$ & 404 & NRC & TPM & 94.37518 & 158.9189 \\
\hline $\begin{array}{r}\$ 04 \\
2683.629\end{array}$ & 404 & NRC & TPM & 88.30268 & 180.6381 \\
\hline $\begin{array}{l}404 \\
2244.961\end{array}$ & 405 & NRC & TPM & 88.30268 & 180.6381 \\
\hline $\begin{array}{c}405 \\
2244.961\end{array}$ & 405 & NRC & TPM & 88.25330 & 177.5726 \\
\hline $\begin{array}{r}405 \\
1983.251\end{array}$ & 406 & NRC & TPM & 88.25330 & 177.5726 \\
\hline $\begin{array}{l}406 \\
1983.251\end{array}$ & 406 & NRC & TPM & 88.19429 & 173.5348 \\
\hline $\begin{array}{l}406 \\
1957.656\end{array}$ & 407 & NRC & TPM & 88.19429 & 173.5348 \\
\hline $\begin{array}{r}407 \\
2043.211\end{array}$ & 407 & NRC & TPM & 79.50454 & 151.7182 \\
\hline $\begin{array}{r}407 \\
2179.768\end{array}$ & $40 B$ & NRC & TPM & $\begin{array}{l}79.50454 \\
\text { Sheet F25 o }\end{array}$ & 151.7182 \\
\hline
\end{tabular}

ATTTACHMENT-F: Calc. No. 0200W-CA-C0156 Rev. No. 0 Job No. 22192 
BHI-01299

Rev. 0

Attachment F: REDOX (Corrected Coordinate in "GT Strud" Model) Output for Seismic Analysis ..... (Using Ground Response Spectrum for "Existing PC3 Structures"- 10\% Damping)

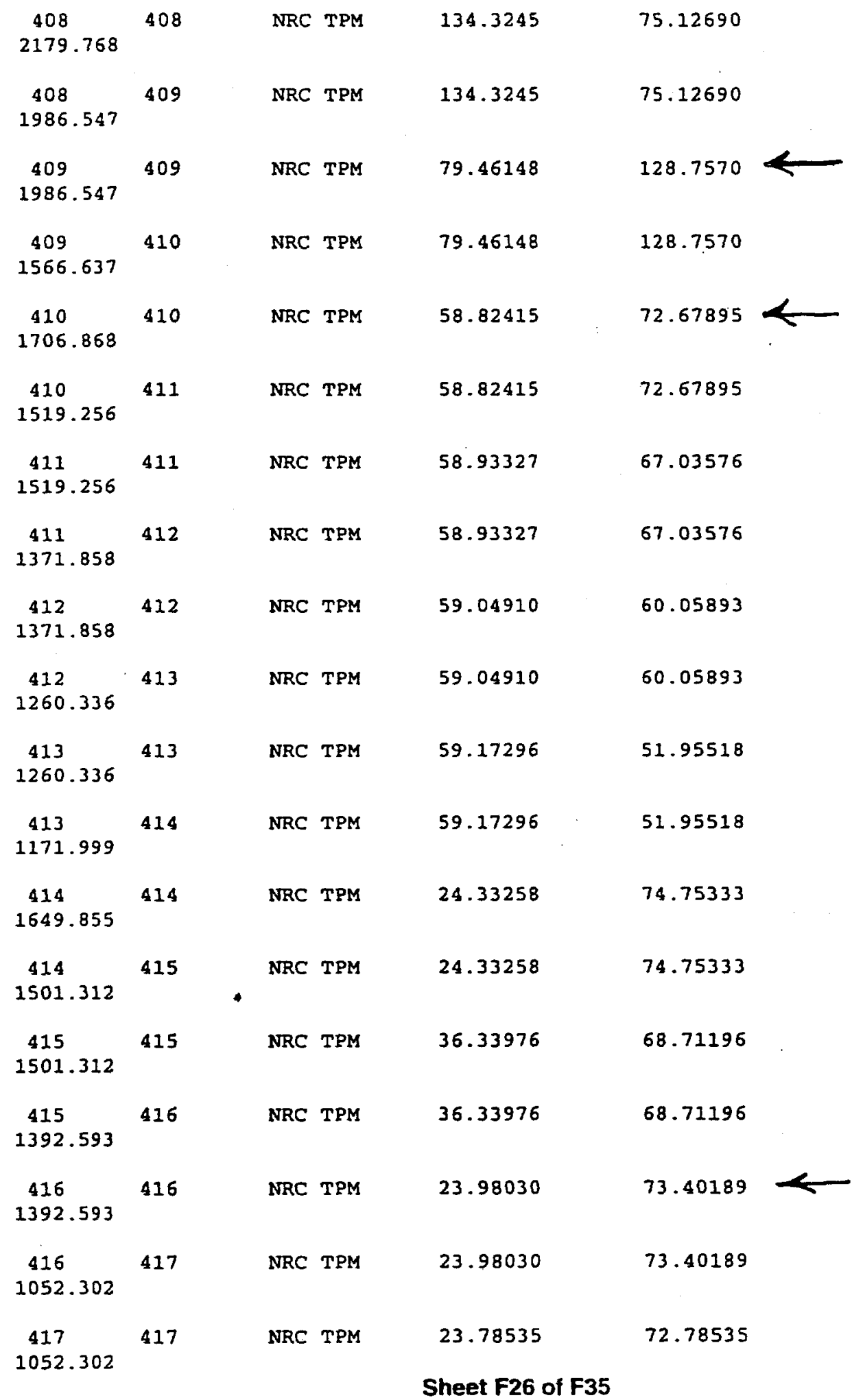

ATITACHMENT-F: Calc. No. 0200W-CA-C0156 Rev. No. 0 Job No. 22192 
BHI-01299

Rev. 0

Attachment F: REDOX (Corrected Coordinate in "GT Strudl" Model) Output for Seismic Analysis (Using Ground Response Spectrum for "Existing PC3 Structures" - 10\% Damping)

\begin{tabular}{|c|c|c|c|c|c|}
\hline $\begin{array}{c}417 \\
709.9069\end{array}$ & 418 & NRC & TPM & 23.78535 & 72.78535 \\
\hline $\begin{array}{l}418 \\
709.9069\end{array}$ & 418 & NRC & TPM & 23.59643 & 71.46213 \\
\hline $\begin{array}{c}418 \\
377.3115\end{array}$ & 419 & NRC & TPM & 23.59643 & 71.46213 \\
\hline $\begin{array}{l}419 \\
68.62672\end{array}$ & 419 & NRC & TPM & 21.91094 & 20.89878 \\
\hline $\begin{array}{l}419 \\
49.76980\end{array}$ & 420 & NRC & TPM & 21.91094 & 20.89878 \\
\hline $\begin{array}{l}420 \\
305.2998\end{array}$ & 420 & NRC & TPM & 22.10268 & 65.94611 \\
\hline $\begin{array}{l}420 \\
39.58980\end{array}$ & 421 & NRC & TPM & 22.10268 & 65.94611 \\
\hline $\begin{array}{c}421 \\
39.58979\end{array}$ & 421 & NRC & TPM & 22.07370 & 63.99404 \\
\hline $\begin{array}{c}421 \\
315.5906\end{array}$ & 422 & NRC & TPM & 22.07370 & 63.99404 \\
\hline $\begin{array}{l}502 \\
327.0619\end{array}$ & 502 & NRC & TPM & 101.4072 & 39.86513 \\
\hline $\begin{array}{l}502 \\
138.8959\end{array}$ & 503 & NRC & TPM & 101.4072 & 39.86513 \\
\hline $\begin{array}{l}503 \\
138.8959\end{array}$ & 503 & NRC & TPM & 101.3999 & 39.54633 \\
\hline $\begin{array}{l}503 \\
53.25641\end{array}$ & 504 & NRC & TPM & 101.3999 & 39.54633 \\
\hline $\begin{array}{l}504 \\
68.04367\end{array}$ & 504 & NRC & TPM & 94.90904 & 9.465829 \\
\hline $\begin{array}{l}504 \\
41.04341\end{array}$ & 505 & NRC & TPM & 94.90904 & 9.465829 \\
\hline $\begin{array}{l}505 \\
41.04341\end{array}$ & 505 & NRC & TPM & 94.89130 & 8.101639 \\
\hline $\begin{array}{l}505 \\
34.68852\end{array}$ & 506 & NRC & TPM & 94.89130 & 8.101639 \\
\hline $\begin{array}{l}506 \\
34.68852\end{array}$ & 506 & NRC & TPM & 94.86865 & 6.921616 \\
\hline $\begin{array}{l}506 \\
46.63928\end{array}$ & 507 & NRC & TPM & & 6.921616 \\
\hline
\end{tabular}

ATTTACHMENT-F: Calc. No. 0200W-CA-C0156 Rev. No. 0 Job No. 22192 
BHI-01299

Rev. 0

Attachment F: REDOX (Corrected Coordinate in "GT Strud!" Model) Output for Seismic Analysis (Using Ground Response Spectrum for "Existing PC3 Structures"- $10 \%$ Damping)

\begin{tabular}{|c|c|c|c|c|c|}
\hline $\begin{array}{l}507 \\
119.3806\end{array}$ & 507 & NRC & TPM & 85.31530 & 15.94025 \\
\hline $\begin{array}{l}507 \\
102.4240\end{array}$ & 508 & NRC & TPM & 85.31530 & 15.94025 \\
\hline $\begin{array}{l}508 \\
102.4240\end{array}$ & 508 & NRC & $T P M$ & 85.28152 & 13.40268 \\
\hline $\begin{array}{l}508 \\
118.0414\end{array}$ & 509 & NRC & $T P M$ & 85.28152 & 13.40268 \\
\hline $\begin{array}{l}509 \\
118.0414\end{array}$ & 509 & NRC & $T P M$ & 85.24345 & 10.78155 \\
\hline $\begin{array}{l}509 \\
146.2219\end{array}$ & 510 & NRC & TPM & 85.24345 & 10.78155 \\
\hline $\begin{array}{l}510 \\
335.4366\end{array}$ & 510 & NRC & TPM & 62.12356 & 49.79796 \\
\hline $\begin{array}{l}510 \\
119.0233\end{array}$ & 511 & NRC & TPM & 62.12356 & 49.79796 \\
\hline $\begin{array}{l}511 \\
119.0233\end{array}$ & 511 & NRC & TPM & 62.08074 & 47.25085 \\
\hline $\begin{array}{c}511 \\
119.6652\end{array}$ & 512 & NRC & TPM & 62.08074 & 47.25085 \\
\hline $\begin{array}{c}512 \\
119.6652\end{array}$ & 512 & NRC & TPM & 62.03682 & 44.31874 \\
\hline $\begin{array}{c}512 \\
310.6389\end{array}$ & 513 & NRC & TPM & 62.03682 & 44.31874 \\
\hline $\begin{array}{c}513 \\
310.6389\end{array}$ & 513 & NRC & TPM & 61.99229 & 41.54208 \\
\hline $\begin{array}{l}513 \\
493.4268\end{array}$ & 514 & NRC & TPM & 61.99229 & 41.54208 \\
\hline $\begin{array}{c}\text { MS1-1 } \\
131.9907\end{array}$ & 104 & NRC & TPM & 9.395149 & 15.57082 \\
\hline $\begin{array}{c}\text { MS1-1 } \\
44.18494\end{array}$ & $s 1-1$ & NRC & TPM & 9.395149 & 15.57082 \\
\hline $\begin{array}{c}\text { MS1-2 } \\
44.18494\end{array}$ & $51-1$ & NRC & TPM & 9.028058 & 15.64039 \\
\hline $\begin{array}{l}\text { MS1-2 } \\
44.00311\end{array}$ & $51-2$ & NRC & TPM & 9.028058 & 15.64039 \\
\hline $\begin{array}{c}M S 1-3 \\
44.00311\end{array}$ & $51-2$ & NRC & TPM & 8.716828 & 15.57429 \\
\hline
\end{tabular}


BHI-01299

Rev. 0

Attachment F: REDOX (Corrected Coordinate in "GT Strudl" Model) Output for Seismic Analysis (Using Ground Response Spectrum for "Existing PC3 Structures"- 10\% Damping)

\begin{tabular}{|c|c|c|c|c|c|}
\hline $\begin{array}{c}\text { MS1-3 } \\
131.8269\end{array}$ & 4 & NRC & TPM & 8.716828 & 15.57429 \\
\hline $\begin{array}{c}\text { MS2-1 } \\
196.4898\end{array}$ & 107 & NRC & TPM & 26.57507 & 23.28846 \\
\hline $\begin{array}{c}\text { MS2-1 } \\
65.16748\end{array}$ & $s 2-1$ & NRC & TPM & 26.57507 & 23.28846 \\
\hline $\begin{array}{c}\text { MS2-2 } \\
65.16748\end{array}$ & $s 2-1$ & NRC & TPM & 25.34591 & 23.38397 \\
\hline $\begin{array}{c}\text { MS2-2 } \\
66.69332\end{array}$ & s2-2 & NRC & TPM & 25.34591 & 23.38397 \\
\hline $\begin{array}{c}\text { MS2-3 } \\
66.69332\end{array}$ & $s 2-2$ & NRC & TPM & 24.18965 & 23.28857 \\
\hline $\begin{array}{c}\text { MS2-3 } \\
198.0155\end{array}$ & 7 & NRC & TPM & 24.18965 & 23.28857 \\
\hline $\begin{array}{c}\text { MS3-1 } \\
281.9719\end{array}$ & 110 & NRC & TPM & 47.61780 & 34.61245 \\
\hline $\begin{array}{c}\text { MS3-1 } \\
115.6400\end{array}$ & s3-1 & NRC & TPM & 47.62780 & 34.61245 \\
\hline $\begin{array}{c}\text { MS3-2 } \\
115.6400\end{array}$ & s3-1 & NRC & TPM & 47.24582 & 34.82430 \\
\hline $\begin{array}{c}\text { MS3-2 } \\
80.74528\end{array}$ & s3-2 & NRC & TPM & 47.24582 & 39.82430 \\
\hline $\begin{array}{c}\text { MS3-3 } \\
80.74528\end{array}$ & s3-2 & NRC & TPM & 46.97997 & 34.74812 \\
\hline $\begin{array}{c}\text { MS3-3 } \\
276.6799\end{array}$ & 10 & NRC & TPM & 46.97997 & 34.74812 \\
\hline $\begin{array}{c}\text { MS4-1 } \\
1001.170\end{array}$ & 113 & NRC & TPM & 125.9154 & 128.3464 \\
\hline $\begin{array}{c}\text { MS4-1 } \\
384.7266\end{array}$ & s4-1 & NRC & TPM & 125.9154 & 128.3464 \\
\hline $\begin{array}{c}\text { MS4-2 } \\
384.7266\end{array}$ & S4-1 & NRC & TPM & 121.8144 & 128.6180 \\
\hline $\begin{array}{c}\text { MS4-2 } \\
341.6636\end{array}$ & $54-2$ & NRC & TPM & 121.8144 & 128.6180 \\
\hline $\begin{array}{c}\text { MS4-3 } \\
341.6636\end{array}$ & $54-2$ & NRC & TPM & 117.5592 & 128.3861 \\
\hline $\begin{array}{c}\text { MS4-3 } \\
1065.200\end{array}$ & 13 & NRC & TPM & 117.5592 & 128.3861 \\
\hline
\end{tabular}

ATITACHMENT-F: Calc. No. 0200W-CA-C0156 Rev. No. 0 Job No. 22192 
BHI-01299

Rev. 0

Attachment F: REDOX (Corrected Coordinate in "GT Strudl”" Model) Output for Seismic Analysis (Using Ground Response Spectrum for "Existing PC3 Structures"- 10\% Damping)

\begin{tabular}{|c|c|c|c|c|c|}
\hline $\begin{array}{c}\text { MS5-1 } \\
105.5647\end{array}$ & 404 & NRC & TPM & 28.29307 & 9.437026 \\
\hline $\begin{array}{c}\text { MS5-1 } \\
33.98245\end{array}$ & $55-1$ & NRC & TPM & 28.29307 & 9.437026 \\
\hline $\begin{array}{c}\text { MS5-2 } \\
33.98245\end{array}$ & $55-1$ & NRC & TPM & 28.75603 & 9.523378 \\
\hline $\begin{array}{c}\text { MS5-2 } \\
38.62722\end{array}$ & $55-2$ & NRC & TPM & 28.75603 & 9.523378 \\
\hline $\begin{array}{c}M S 5-3 \\
38.62722\end{array}$ & $s 5-2$ & NRC & $\mathrm{TPM}$ & 29.28195 & 9.367605 \\
\hline $\begin{array}{c}\text { MS5-3 } \\
109.6945\end{array}$ & 504 & NRC & TPM & 29.28195 & 9.367605 \\
\hline $\begin{array}{c}M S 6-1 \\
140.4419\end{array}$ & 407 & NRC & TPM & 19.74050 & 12.01482 \\
\hline $\begin{array}{c}\text { MS6-1 } \\
49.15977\end{array}$ & $56-1$ & NRC & TPM & 19.74050 & 12.01482 \\
\hline $\begin{array}{c}\text { MS6-2 } \\
49.15977\end{array}$ & $56-1$ & NRC & TPM & 17.25685 & 12.18775 \\
\hline $\begin{array}{c}\text { MS6-2 } \\
43.66436\end{array}$ & $56-2$ & NRC & TPM & 17.25685 & 12.18775 \\
\hline $\begin{array}{c}M S 6-3 \\
43.66436\end{array}$ & $56-2$ & NRC & TPM & 14.81274 & 12.07166 \\
\hline $\begin{array}{c}\text { MS6-3 } \\
135.4386\end{array}$ & 507 & NRC & TPM & 14.81274 & 12.07166 \\
\hline $\begin{array}{c}\text { MS7-1 } \\
242.6143\end{array}$ & 410 & NRC & TPM & 55.09815 & 23.80188 \\
\hline $\begin{array}{c}\text { MS7-1 } \\
117.7421\end{array}$ & $57-1$ & NRC & TPM & 55.09815 & 23.80188 \\
\hline $\begin{array}{c}\text { MS7-2 } \\
117.7421\end{array}$ & $57-1$ & NRC & TPM & 53.68487 & 23.93988 \\
\hline $\begin{array}{c}\text { MS7-2 } \\
65.14295\end{array}$ & $57-2$ & NRC & TPM & 53.68487 & 23.93988 \\
\hline $\begin{array}{l}\text { MS7-3 } \\
65.14295\end{array}$ & $57-2$ & NRC & TPM & 52.25924 & 24.07491 \\
\hline $\begin{array}{c}\text { MS7-3 } \\
246.4440\end{array}$ & 510 & NRC & TPM & 52.25924 & 24.07491 \\
\hline 58-1 & 414 & NRC & TPM & 40.09366 & 61.26771 \\
\hline
\end{tabular}

768.9380 
Attachment F: REDOX (Corrected Coordinate in "GT Strudl" Model) Output for Seismic Analysis ...... (Using Ground Response Spectrum for "Existing PC3 Structures"-10\% Damping)

\begin{tabular}{|c|c|c|c|c|c|}
\hline $\begin{array}{c}\text { MS8-1 } \\
446.3404\end{array}$ & $58-1$ & NRC & TPM & 40.09366 & 61.26771 \\
\hline $\begin{array}{c}M S 8-2 \\
446.3404\end{array}$ & $58-1$ & NRC & TPM & 38.82933 & 61.62537 \\
\hline $\begin{array}{c}\text { MS8-2 } \\
31.50931\end{array}$ & $s 8-2$ & NRC & TPM & 38.82933 & 61.62537 \\
\hline $\begin{array}{c}\text { MS8-3 } \\
31.50931\end{array}$ & $S 8-2$ & NRC & TPM & 39.33063 & 61.94218 \\
\hline $\begin{array}{c}M S 8-3 \\
493.4268\end{array}$ & 514 & NRC & TPM & 39.33063 & 61.94218 \\
\hline $\begin{array}{c}\text { MS } 9-1 \\
202.3282\end{array}$ & 303 & NRC & TPM & 0.8264268 & 36.78742 \\
\hline $\begin{array}{c}\text { MS9-1 } \\
0.4879480\end{array}$ & $\underset{E-01}{S 9-1}$ & NRC & TPM & 0.8264268 & 36.78742 \\
\hline $\begin{array}{c}\text { MS9-2 } \\
0.4879489\end{array}$ & $\begin{array}{l}59-1 \\
E-01\end{array}$ & NRC & TPM & 0.8158386 & 36.78741 \\
\hline $\begin{array}{c}\text { MS9-2 } \\
202.3334\end{array}$ & 203 & NRC & TPM & 0.8158386 & 36.78741 \\
\hline $\begin{array}{c}\text { MTR-1 } \\
96.02198\end{array}$ & 308 & NRC & TPM & 172.0426 & 64.02771 \\
\hline $\begin{array}{c}\text { MTR-1 } \\
96.06731\end{array}$ & 208 & NRC & TPM & 172.0426 & 64.02771 \\
\hline $\mathrm{CC}-1$ & 108 & NRC & TPM & 171.0916 & \\
\hline $\mathrm{cc}-2$ & 308 & NRC & TPM & 175.1949 & \\
\hline$M T-1$ & $T-2$ & NRC & TPM & 2.024876 & \\
\hline $\mathrm{MT}-2$ & $T-3$ & NRC & TPM & 35.93516 & \\
\hline$M T-3$ & $T-4$ & NRC & TPM & 55.85269 & \\
\hline$M T-4$ & $T-5$ & NRC & TPM & 59.47759 & \\
\hline$M T-5$ & $T-6$ & NRC & TPM & 51.94580 & \\
\hline MT- 6 & $T-7$ & NRC & TPM & 8.413983 & \\
\hline $\mathrm{MT}-7$ & $T-9$ & NRC & TPM & 19.09814 & \\
\hline$M T-8$ & $T-10$ & NRC & TPM & 19.15832 & \\
\hline MT-9 & $T-11$ & NRC & TPM & 47.02917 & \\
\hline$M T-10$ & $\mathrm{~T}-12$ & NRC & TPM & $\begin{array}{c}47.06139 \\
\text { Sheet F31 }\end{array}$ & \\
\hline
\end{tabular}

ATTTACHMENT-F: Calc. No. 0200 W-CA-C0156 Rev. No. 0 Job No. 22192 
BHI-01299

Rev. 0

Attachment F: REDOX (Corrected Coordinate in "GT Strudl" Model) Output for Seismic Analysis (Using Ground Response Spectrum for "Existing PC3 Structures"- 10\% Damping)

\begin{tabular}{|c|c|c|c|c|}
\hline$M T-11$ & $T-13$ & NRC TPM & 58.55695 & \\
\hline$M T-12$ & $T-14$ & NRC TPM & 58.54820 & \\
\hline$M T-13$ & $T-15$ & NRC TPM & 54.40409 & \\
\hline$M T-14$ & $T-16$ & NRC TPM & 54.35825 & \\
\hline$M T-15$ & $T-17$ & NRC TPM & 35.11818 & \\
\hline MT-16 & $T-18$ & NRC TPM & 35.06207 & \\
\hline$M T-17$ & $T-8$ & NRC TPM & 34.40853 & \\
\hline$M T-18$ & $T-8$ & NRC TPM & 30.52154 & \\
\hline$M T-19$ & $T-9$ & NRC TPM & 2.941134 & \\
\hline$M T-20$ & $T-10$ & NRC TPM & 27.38610 & \\
\hline$M T-21$ & $T-10$ & NRC TPM & 18.63957 & \\
\hline$M T-22$ & $T-11$ & NRC TPM & 3.998488 & \\
\hline$M T-23$ & $T-12$ & NRC TPM & 15.92473 & \\
\hline MT -24 & $T-12$ & NRC TPM & 10.96755 & \\
\hline$M T-25$ & $T-13$ & NRC TPM & 4.529173 & \\
\hline MT-26 & $T-14$ & NRC TPM & 10.70206 & \\
\hline$M T-27$ & $T-14$ & NRC TPM & 16.11627 & \\
\hline$M T-28$ & $T-15$ & NRC TPM & 4.141054 & \\
\hline MT-29 & $T-16$ & NRC TPM & 19.25900 & \\
\hline MT -30 & $T-16$ & NRC TPM & 28.13541 & \\
\hline$M T-31$ & $T-17$ & NRC TPM & 29.40735 & \\
\hline $\mathrm{MT}-32$ & $T-18$ & NRC TPM & 56.12450 & \\
\hline MT-33 & $T-18$ & NRC TPM & 26.52252 & $:$ \\
\hline $\begin{array}{l}\text { MTC-1 } \\
103.3058\end{array}$ & 19 & NRC TPM & 22.71149 & 20.56891 \\
\hline $\begin{array}{l}\text { MTC-1 } \\
85.44615\end{array}$ & 30 & NRC TPM & 22.71149 & 20.56891 \\
\hline $\begin{array}{c}\text { MTC-2 } \\
102.1195\end{array}$ & 20 & NRC TPM & 17.65244 & 23.37032 \\
\hline
\end{tabular}


BHI-01299

Rev. 0

Attachment F: REDOX (Corrected Coordinate in "GT Strudl" Model) Output for Seismic Analysis (Using Ground Response Spectrum for "Existing PC3 Structures"- 10\% Damping)

\begin{tabular}{|c|c|c|c|c|c|}
\hline $\begin{array}{l}\text { MTC-2 } \\
85.44615\end{array}$ & 30 & NRC & TPM & 17.65244 & 23.37032 \\
\hline $\begin{array}{c}\text { MTC-11 } \\
308.6962\end{array}$ & 419 & NRC & TPM & 19.95539 & 64.86092 \\
\hline $\begin{array}{c}\text { MTC-11 } \\
250.9409\end{array}$ & 430 & NRC & TPM & 19.95539 & 64.86092 \\
\hline $\begin{array}{c}\text { MTC-12 } \\
255.5544\end{array}$ & 420 & NRC & TPM & 57.46773 & 6.872303 \\
\hline $\begin{array}{c}\text { MTC-12 } \\
250.6183\end{array}$ & 430 & NRC & TPM & 57.46773 & 6.872303 \\
\hline $\begin{array}{c}\text { MTC-13 } \\
5.560268\end{array}$ & 430 & NRC & TPM & 26.55978 & 10.26511 \\
\hline $\begin{array}{c}\text { MTC-13 } \\
0.1154347\end{array}$ & $\begin{array}{r}T-7 \\
E-06\end{array}$ & NRC & TPM & 26.55978 & 10.26511 \\
\hline MRS-1 & RS-1 & NRC & TPM & 30.98965 & \\
\hline MTC-3 & $T-1$ & NRC & TPM & 34.41060 & \\
\hline $\begin{array}{c}\text { MRS-2 } \\
0.45222441\end{array}$ & $\begin{array}{l}\text { RS-1 } \\
2-07\end{array}$ & NRC & TPM & 0.5115922 & 31.02460 \\
\hline $\begin{array}{c}\text { MRS-2 } \\
23.26845\end{array}$ & RS-2 & NRC & TPM & 0.5115922 & 31.02460 \\
\hline $\begin{array}{c}\text { MRS-3 } \\
23.26846\end{array}$ & RS-2 & NRC & TPM & 3.936304 & 2.400116 \\
\hline $\begin{array}{l}\text { MRS-3 } \\
12.80744\end{array}$ & RS-3 & NRC & TPM & 3.936304 & 2.400116 \\
\hline $\begin{array}{c}\text { MRS-4 } \\
12.80744\end{array}$ & RS-3 & NRC & TPM & 10.00918 & 1.527681 \\
\hline $\begin{array}{c}\text { MRS-4 } \\
6.142187\end{array}$ & RS-4 & NRC & TPM & 10.00918 & 1.527681 \\
\hline $\begin{array}{l}\text { MRS-5 } \\
6.142194\end{array}$ & RS-4 & NRC & TPM & 16.04045 & 2.637140 \\
\hline $\begin{array}{c}\text { MRS-5 } \\
22.11033\end{array}$ & RS-5 & NRC & TPM & 16.04045 & 2.637140 \\
\hline $\begin{array}{c}\text { MRS-6 } \\
22.11033\end{array}$ & RS-5 & NRC & TPM & 22.07035 & 0.9355739 \\
\hline $\begin{array}{c}\text { MRS-6 } \\
18.61101\end{array}$ & RS-6 & NRC & TPM & 22.07035 & 0.9355739 \\
\hline $\begin{array}{c}\text { MRS-7 } \\
18.61101\end{array}$ & RS- 6 & NRC & TPM & 28.09836 & 1.724940 \\
\hline
\end{tabular}

18.61101 
BHI-01299

Rev. 0

Attachment F: AEDOX (Corrected Coordinate in "GT Strudl" Model) Output for Seismic Analysis (Using Ground Response Spectrum for "Existing PC3 Structures"- 10\% Damping)

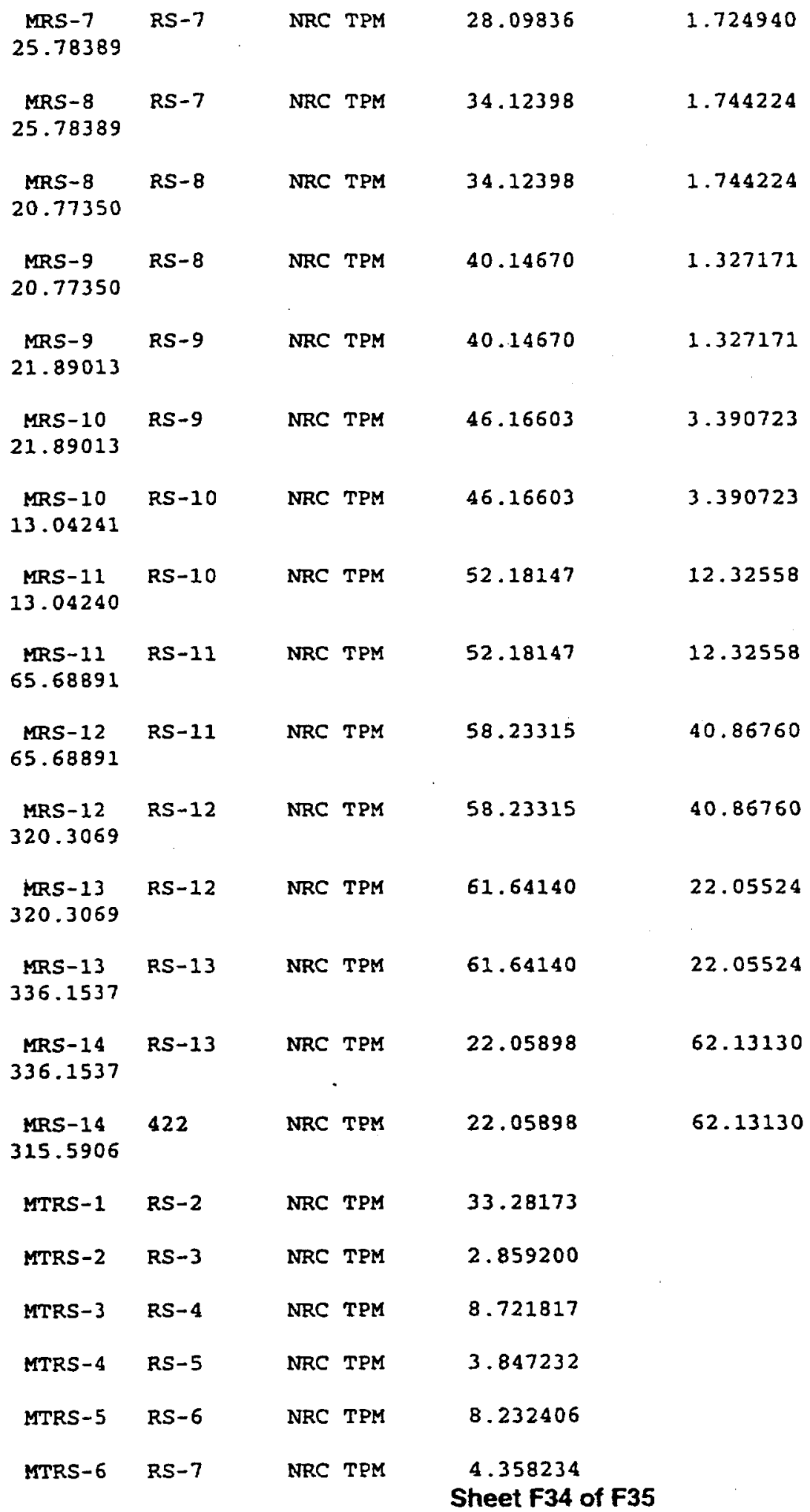

ATTTACHMENT-F: Calc. No. D200W-CA-C0156 Rev. No. 0 Job No. 22192 
BHI-01299

Rev. 0

Attachment F: REDOX (Corrected Coordinate in "GT Strudl" Model) Output for Seismic Analysis (Using Ground Response Spectrum for "Existing PC3 Structures"- 10\% Damping)

$\begin{array}{llll}\text { MTRS-7 } & \text { RS-8 } & \text { NRC TPM } & 8.212537 \\ \text { MTRS-8 } & \text { RS-9 } & \text { NRC TPM } & 3.999424 \\ \text { MTRS-9 } & \text { RS-10 } & \text { NRC TPM } & 17.23706 \\ \text { MTRS-10 } & \text { RS-11 } & \text { NRC TPM } & 29.38590 \\ \text { MTRS-11 } & \text { RS-12 } & \text { NRC TPM } & 20.42242 \\ (456\}> & & \\ (457\}> & & \\ (458)> & \\ (459)> & \\ (460)> & \end{array}$


BHI-01299

Rev. 0

A-168 
BHI-01299

Rev. 0

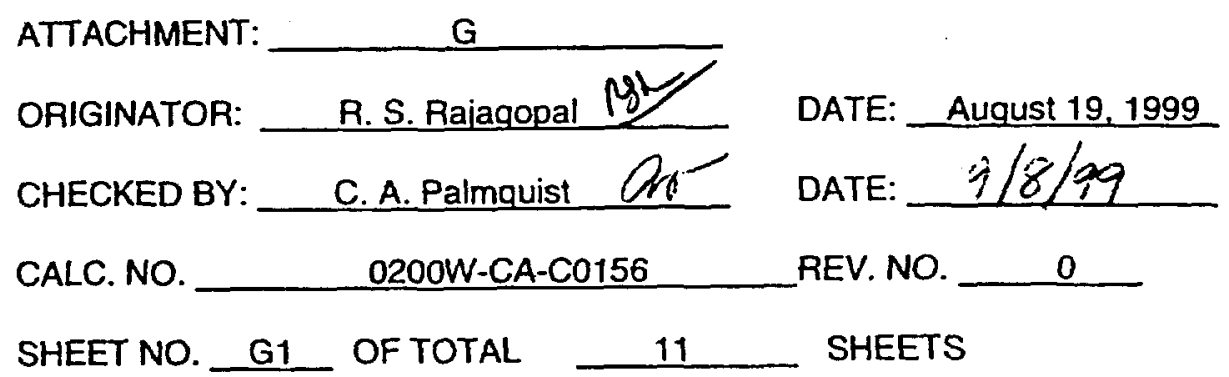

ATTACHMENT "G"

REDOX "GT Strud?" Model: Excerpted from Ref. 7

(Figures 1, 2A-2E, 3, 4, 5, \& 6) 

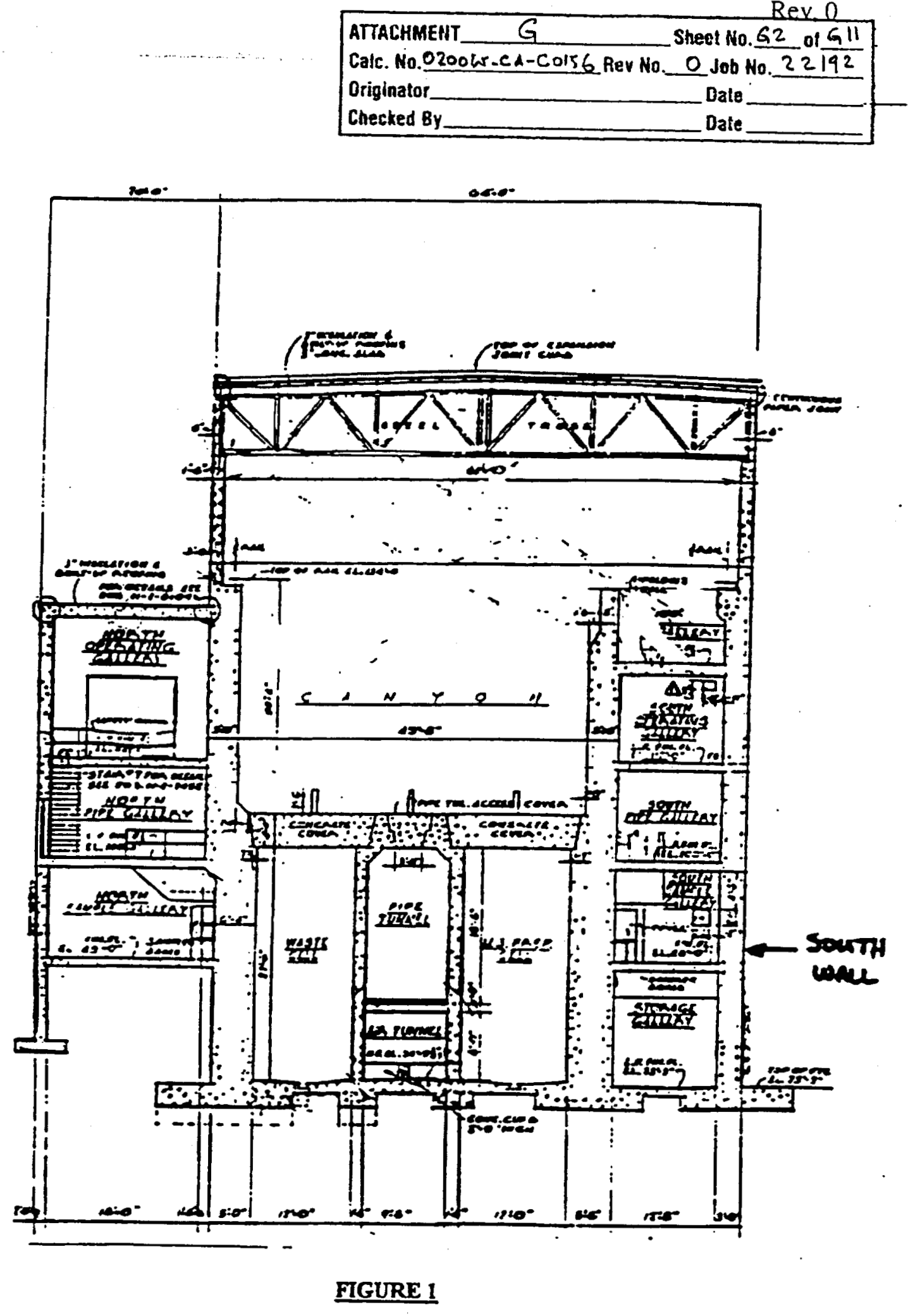

TYPICAL NORTH SOUTH SECTION 


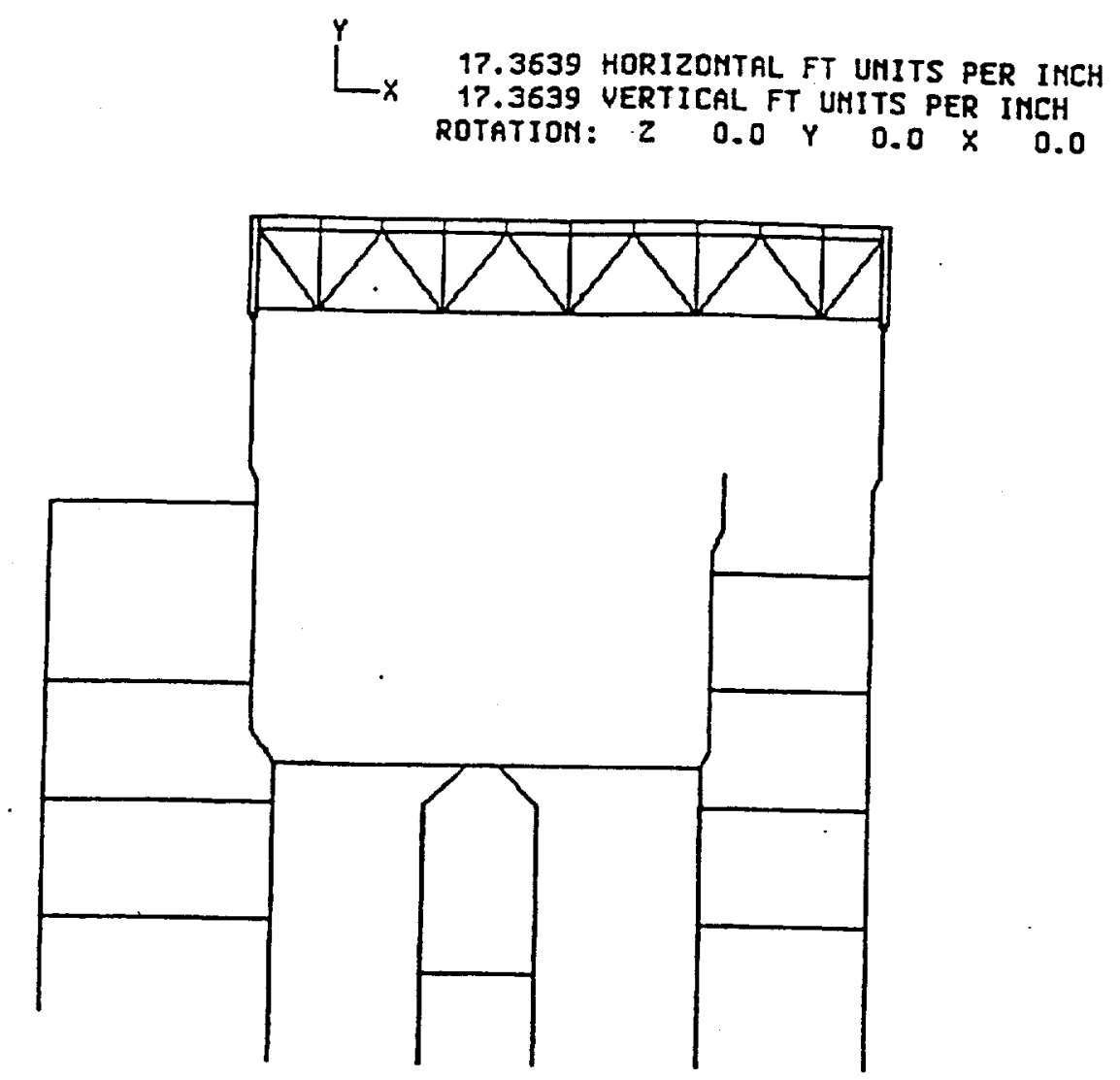

Enter Consands

FTGURE 2A

ANALYTICAL MODEL FOR SEISMIC ANALYSIS

\begin{tabular}{|c|c|}
\hline ATTACHMENT_G $G$ & _ Sheet No. G3 of Gll \\
\hline Calc. No. & Rey No.___ Job No. 22192 \\
\hline Driginator_ & _ Date. \\
\hline Checked By & EDate \\
\hline
\end{tabular}


BHI-01299

Rev. 0
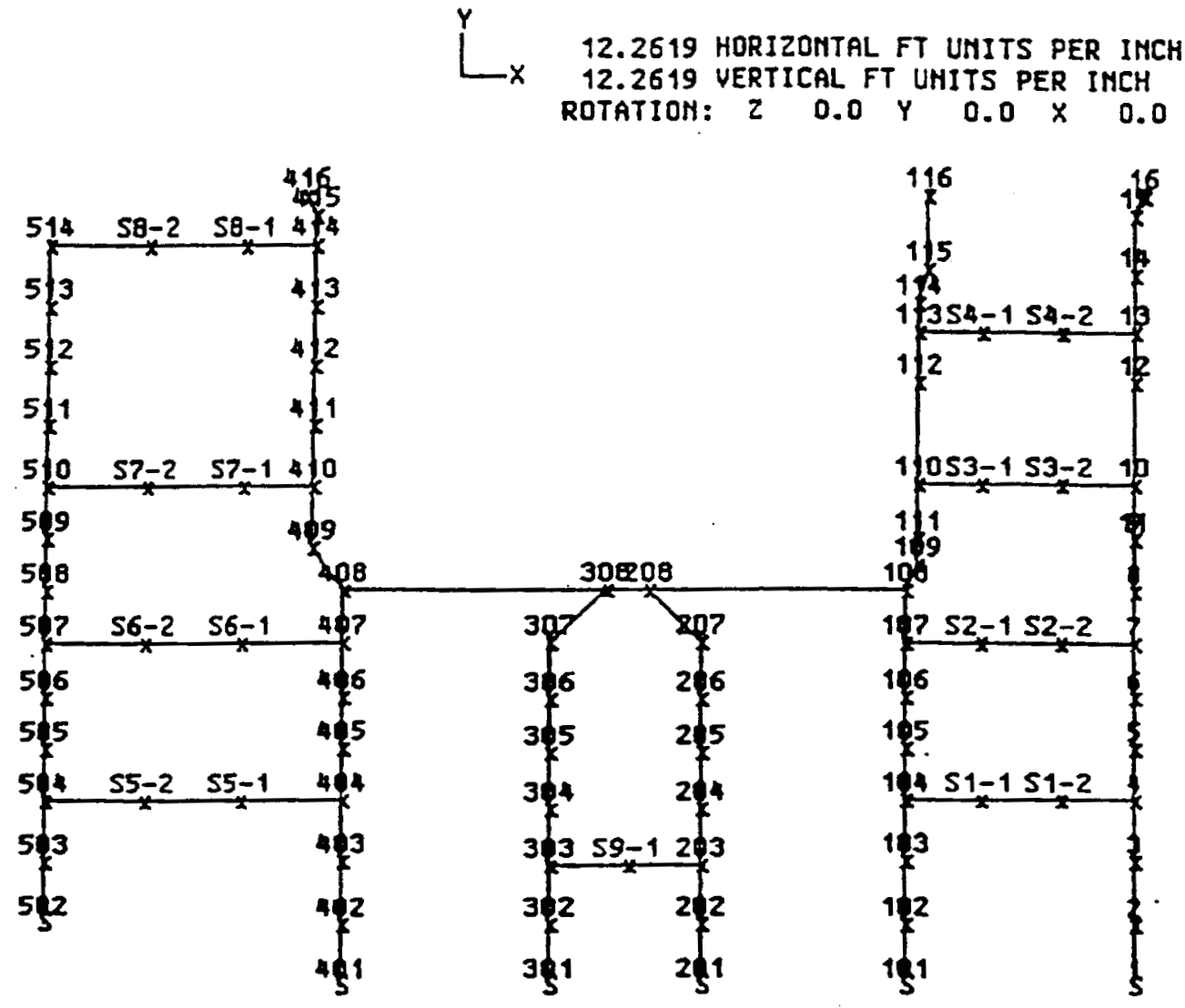

L J

Enter Comands

\section{FIGURE 2B}

ANALYTICAL MODEL BELOW 133' 4"

JOINT NUMBER DESIGNATION

ATTACHMENT

Caic. No.

Originalor

Checked By
Sheel No. G4 of Gll

Rev Ho. Job No. 22198 Data

Date 
BHI-01299

Rev. 0
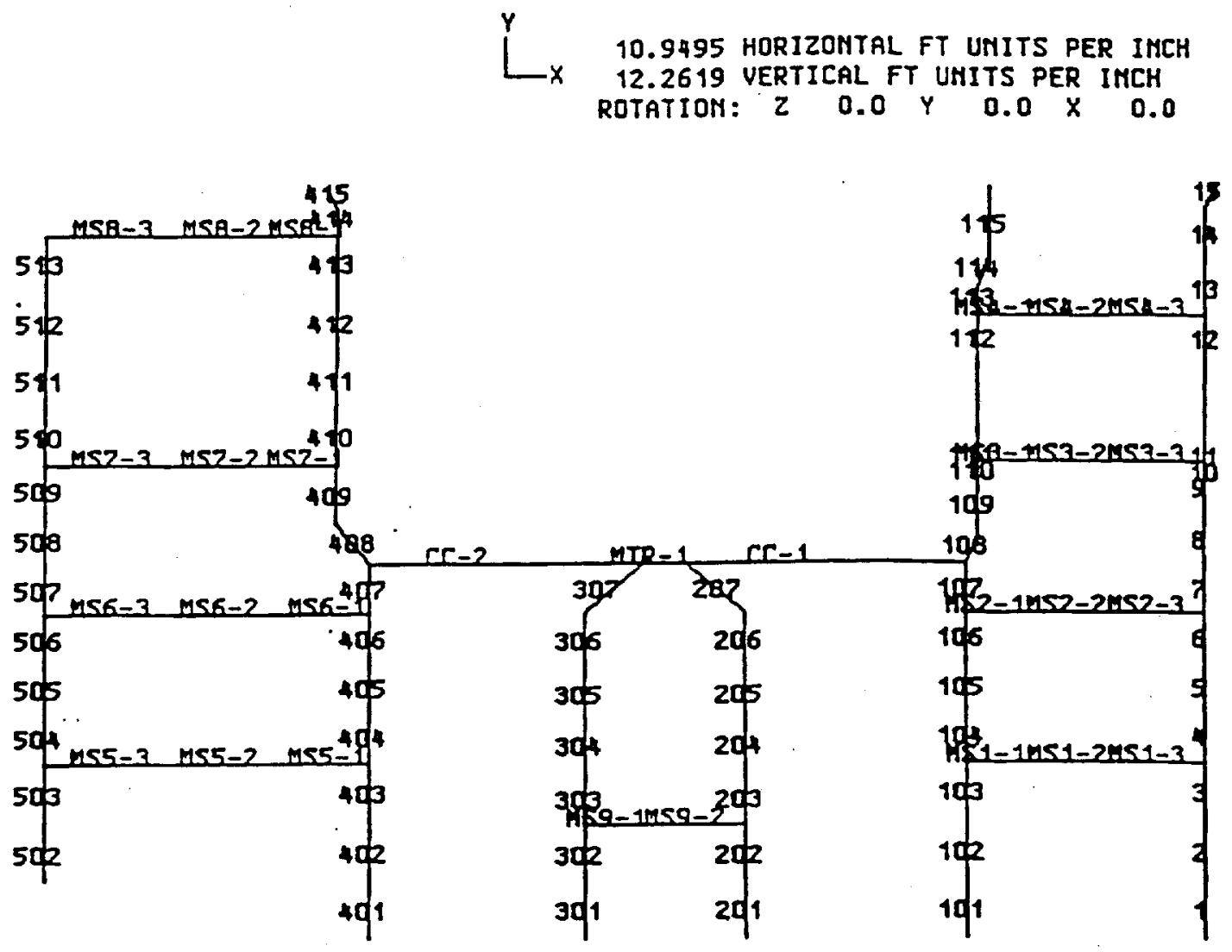

L $n$

Enter Counands

FIGURE 2C

ANALYTTCAL MODEL BELOW 133' 4"

MEMBER NUMBER DESIGNATION

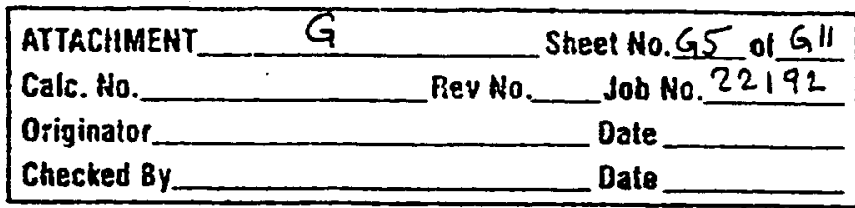


BHI-01299

Rev. 0

8.4312 HORIZOMTAL FT UMITS PER IMCH 0.4312 VERTICAL FT UNITS PER IMCH ROTATIOH: $Z 0.0$ Y $0.0 \times 0.0$

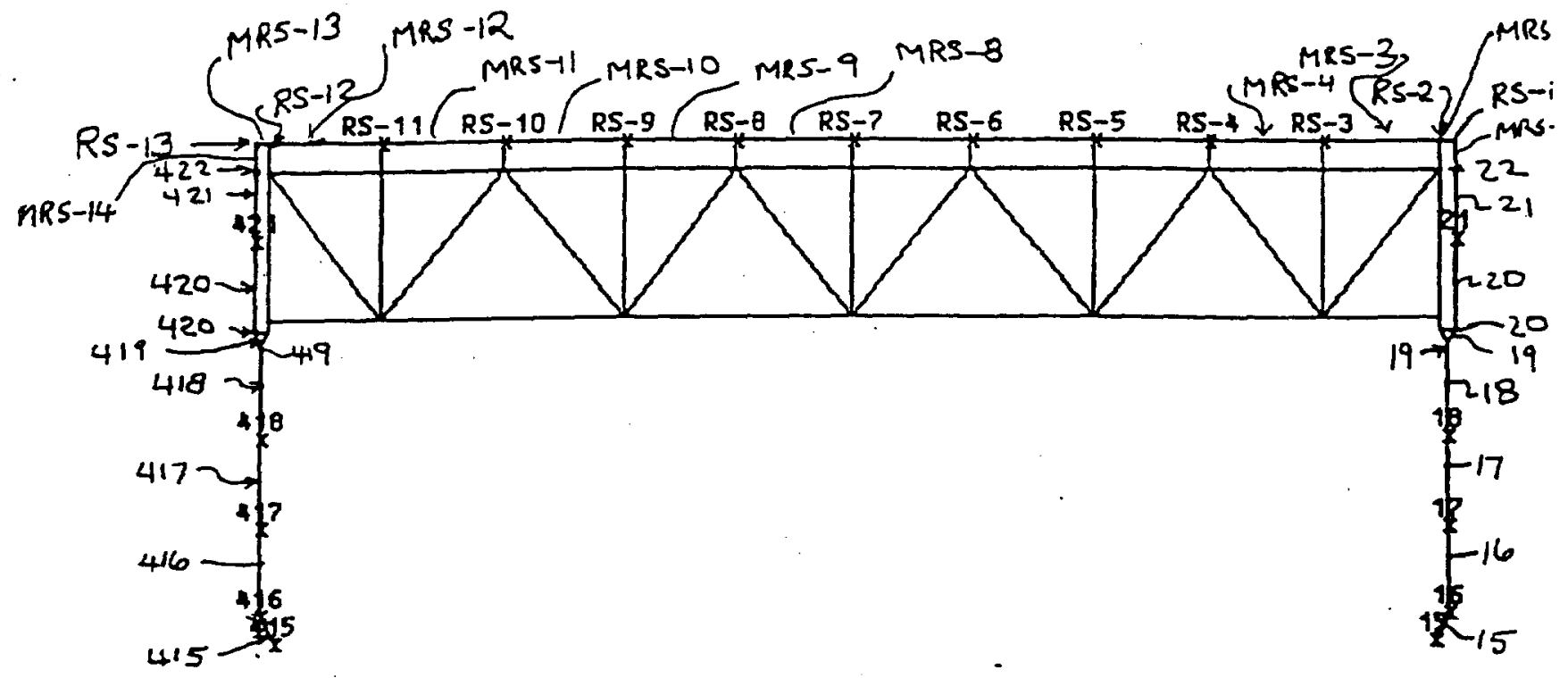

L J 'RS-3' TO 'RS-19'

Enter Conaands

FGURE 2D

ANALYTICAL MODEL ABOVE EL 133' 4n

JOINT \& MEMBER DESIGNATION

(CONCRETE MEMBERS ONLY)

\begin{tabular}{lr}
\hline ATTACHMENT_G & Sheet No. G6 ol $G 11$ \\
Calc. No. & P.ev No. Job No. 22192 \\
Originator & Date \\
Checked By & Date \\
\hline
\end{tabular}


BHI-01299

Rev. 0

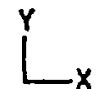

8.4312 HORIZDNTAL FT UNITS PER IHCH

8. 4312 VERTICAL FT UHITS PER IHCH

ROTATION: $Z$ 0.0 Y 0.0 Y 0.0

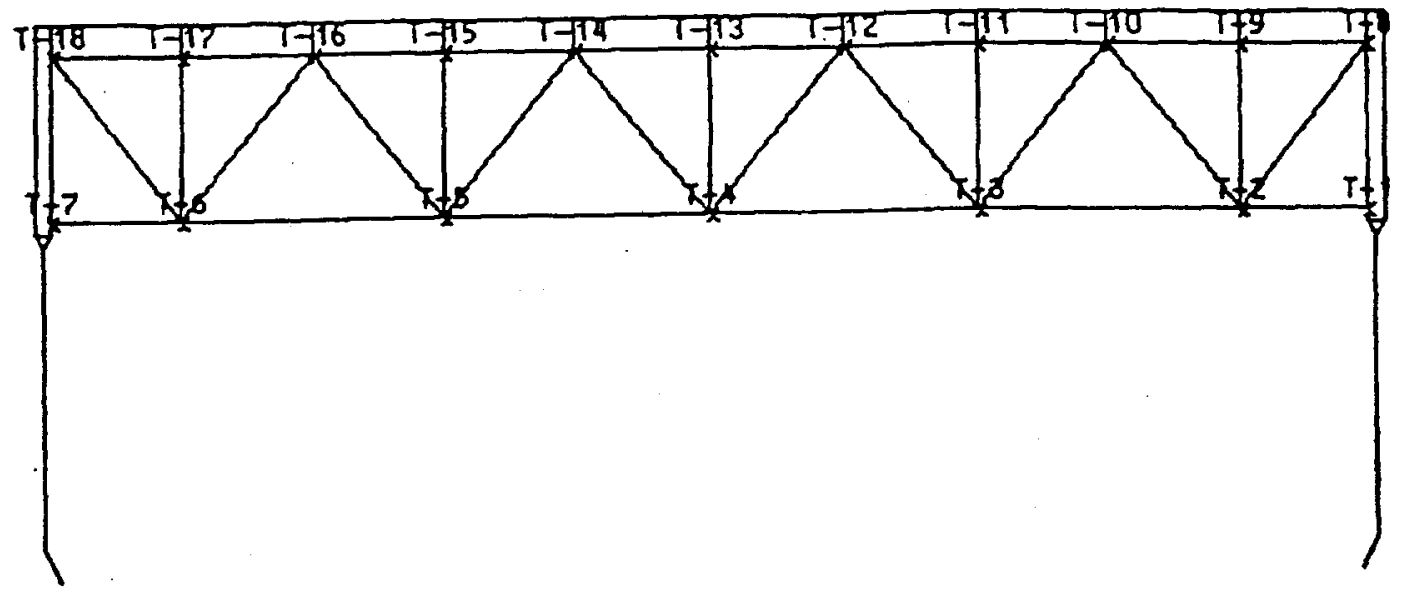

$L$ J 'T-1' TO 'T-18'

Enter Comand?

FIGURE 2E

ROOF TRUSS - JOINT DESIGNATION

\begin{tabular}{|c|c|}
\hline ATTACHMENT_ $\quad G$ & Sheet No. G7 of GII \\
\hline Calc. No. & Job No. 22192 \\
\hline Originator & Dale \\
\hline Checked By & Date \\
\hline
\end{tabular}


BHI-01299

Rev. 0

L 3

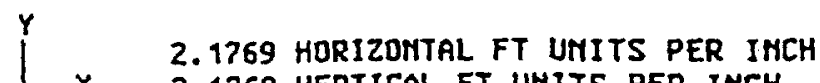

2.1769 VERTICAL FT UHITS PER INCH

ROTATION: $Z 0.0$ Y $0.0 \times 0.0$

l

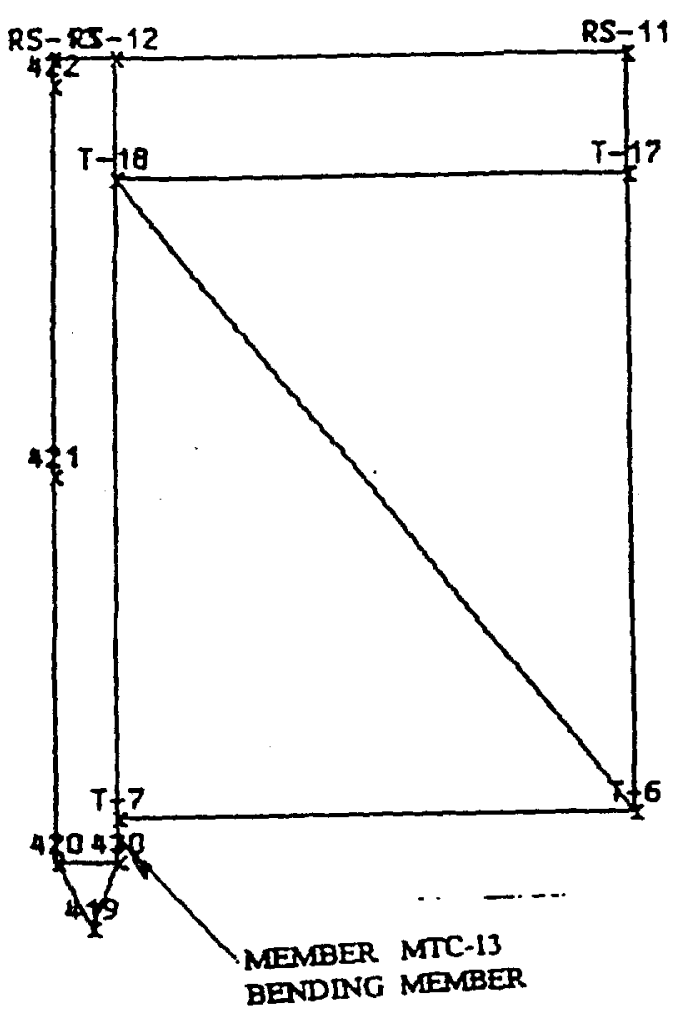

Enter Comaond?

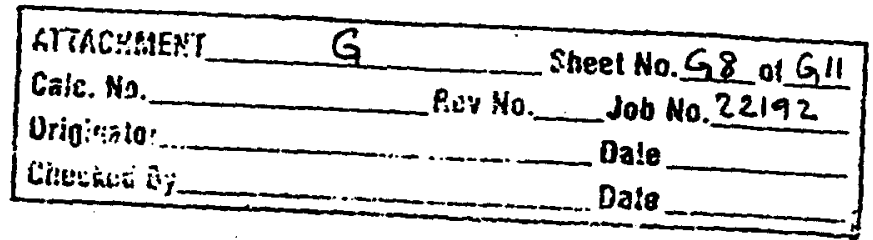

FIGURE 3

CONNECTION BETWEEN TRUSS \& BLDG STRUCTURE

(NORTB SIDE - 1" * BOLTS WITH $1^{5} /$ ac $^{n}$, BOLES) 
BHI-01299

Rev. 0

$r$ DIA LD HS AT 390.03 FT-KP/IH

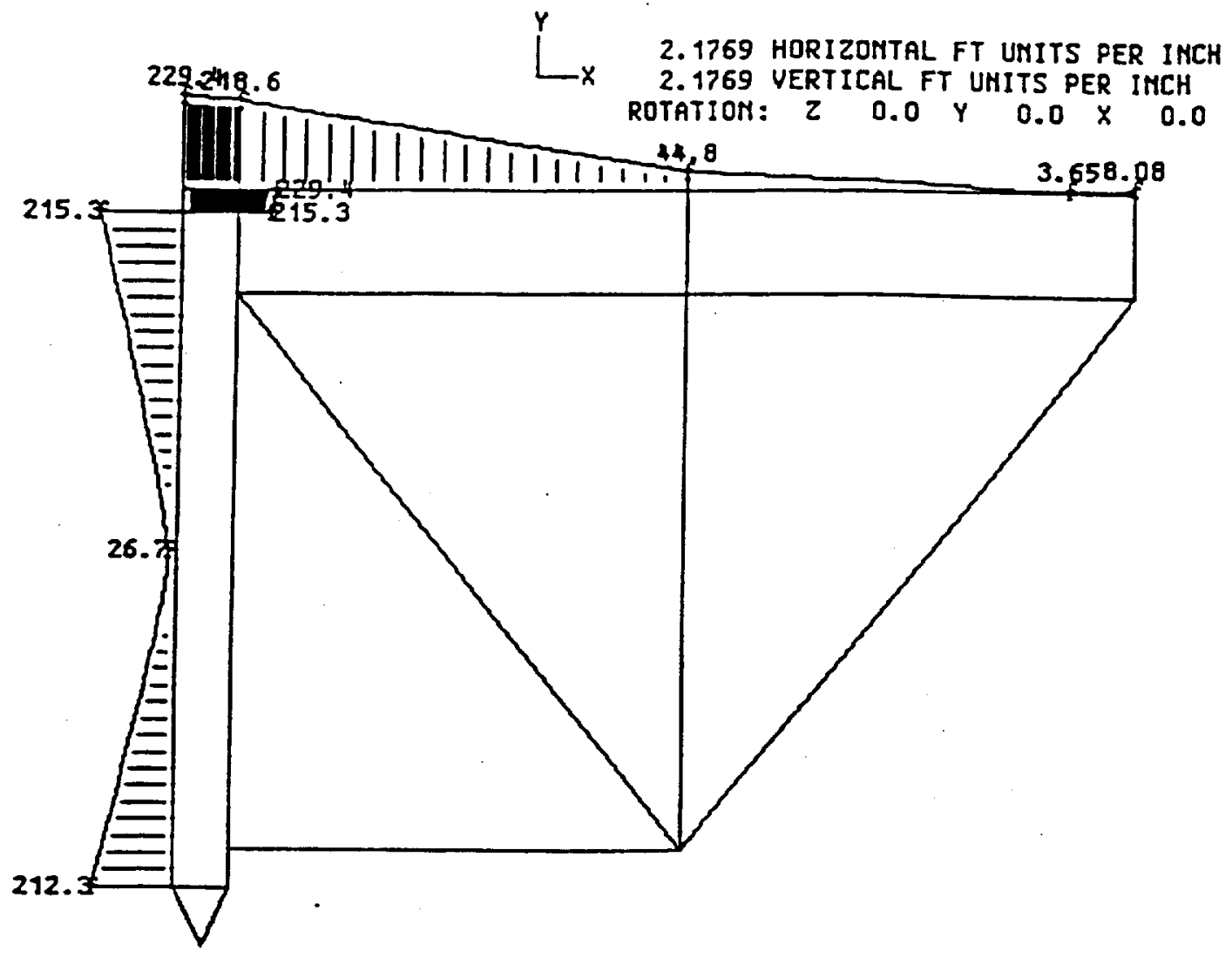

L 0

Enter Coanand)

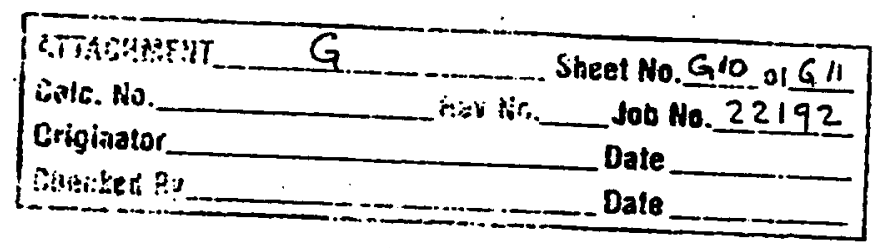

FIGURE 5

BENDING MOMENT DLAGRAM AT ROOF SLAB \& NORTH WALL JUNCTION (MONOLITHIC CONNECTION) 
BHI-01299

Rev. 0

$\because$ DIA LD NS AT 145.14 FT-KP/IN
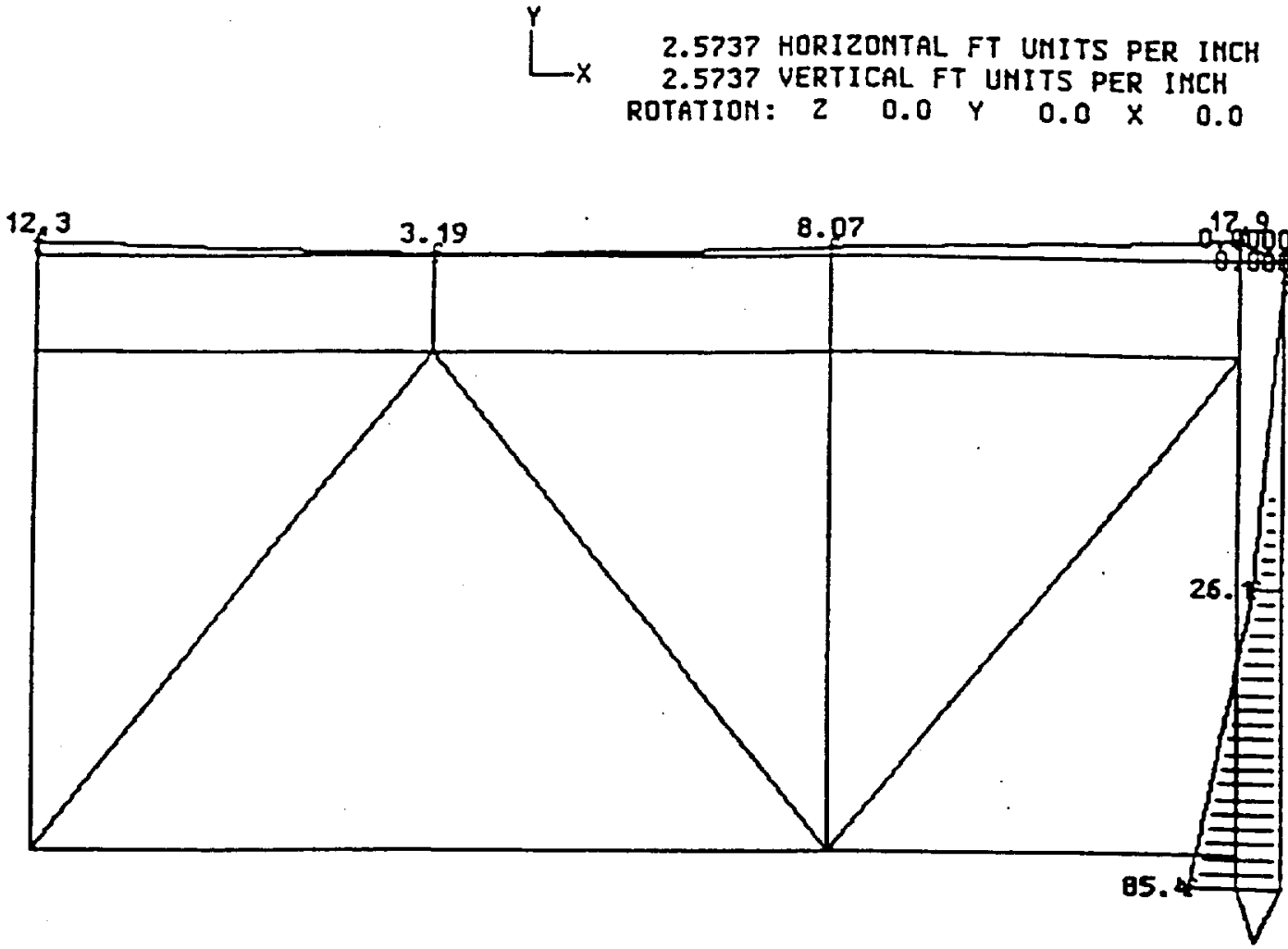

L D

Enter Comand)

FIGURE 6

BENDING MOMENT DLAGRAM AT ROOF SLAB

\& SOUTH WALL CONNECTION

(PAPER JOENT BETWEEN WALL \& ROOF SLAB)

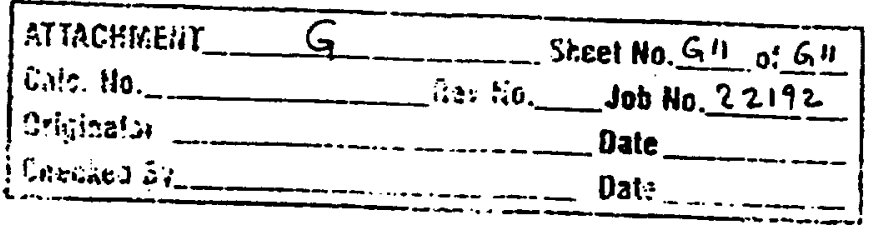


BHI-0 1299

Rev. 0 
BHI-01299

Rev. 0

\section{DISTRIBUTION}

U.S. Department of Energy,

Richland Operations Office

P. M. Pak

$\mathrm{H} 0-12$

J. P. Sands (5)

$\mathrm{H} 0-12$

S. S. Seth

A5-11

ERC Team

N. R. Kerr, BHI S3-21

R. G. Egge, BHI S3-21

G. L. Funnell, BHI - T7-05

R. P. Henckel, BHI S3-21

C. J. Kemp, BHI S3-20

R. J. Landon, BHI H0-02

M. A. Mihalic, BHI X9-08

J. J. McGuire, BHI \$3-20

R. S. Rajagopal, BHI H0-18

D. D. Teel, BHI HO-23

R. G. Shuck, BHI T7-05

P.J. Woods, BHI S3-20

J. P. Zoric, BHI X5-53

Document and Information Services (3) H0-09

DOE-RL Public Reading Room H2-53

Hanford Technical Library P8-55 
BHI-01299

Rev. 0 